GRZEGORZ KLOSKOWSKI* - GDAŃSK

\title{
KARMELICI TRZEWICZKOWI PROWINCJI WIELKOPOLSKIEJ W XVII-XIX WIEKU
}

Inspiracją do napisania poniższego artykułu była „Kroniczka rezydencji Karmelitów Trzewiczkowych w Poznaniu"1. Jej autor pisze we wstępie o braku informacji o karmelitach trzewiczkowych, o braku opracowań źródłowych. Poniższe zestawienie jest pierwszym opracowaniem źródłowym dotyczącym bezpośrednio zakonników prowincji wielkopolskiej. Ukazane dane wyczerpują jedynie podane źródła i stanowią podstawę do dalszych badań nad tą rodziną zakonną.

Karmelici - Zakon Braci Najświętszej Maryi Panny z Góry Karmel (Ordo Fratrum Beatissimae Mariae Virginis de Monte Carmelo). Jest to klerycki zakon żebrzący o charakterze apostolskim, nawiązujący do ideałów i duchowości pustelników z Góry Karmel w Ziemi Świętej. Zakonnicy szerzyli kult maryjny przez zakładanie bractw szkaplerznych i upowszechnianie świąt maryjnych. Patronami zakonu są święci Eliasz i Elizeusz.

Pierwsze klasztory na ziemiach polskich należały do prowincji saksońskiej, z której w 1462 wydzielono prowincję czesko-polską. Prowincja polska powstała w pierwszej połowie XVI wieku. Klasztory na terenie Wielkopolski przyjmowały stopniowo reformę obserwancką, tworząc od 1686 osobną kongregację strictioris observantiae. W 1728 została wydzielona osobna prowincja wielkopolska pod wezwaniem Najświętszego Sakramentu².

Najstarszy klasztor późniejszej prowincji wielkopolskiej został złożony na przedmieściach Gdańska przez mistrza krzyżackiego Winricha v. Kniperode (1351-1382). W 1455 zakonnicy przenieśli się w obręb miasta. Kolejnymi ośrodkami prowincji były: Bydgoszcz (1398), Poznań (1399), Płońsk (1462), Lipie

${ }^{*}$ Grzegorz Kloskowski - współpracownik Archiwum Diecezjalnego w Pelplinie.

${ }^{1}$ Kroniczka rezydencji Karmelitów Trzewiczkowych $w$ Poznaniu przy kościele Najświętszej Krwi Pana Jezusa na ul. Żydowskiej, oprac. J. Wiesiołowski, Poznań 2005 (dalej cyt.: Kroniczka).

${ }^{2}$ Do prowincji wielkopolskiej należały klasztory: Bydgoszcz (archidiecezja gnieźnieńska), Drohobycz (diecezja przemyska), Gdańsk (włocławska), Kcynia (gnieźnieńska), Kłodawa (gnieźnieńska), Lipie (poznańska), Markowice (włocławska), Obory (płocka), Płońsk (płocka), Poznań (poznańska), Trutowo (płocka) i Warszawa-Leszno (poznańska). 
(1605), Obory (1605), Kcynia (1612), Kłodawa (1623), Markowice (1643), Warszawa (1683) i Trutowo (1717). Do prowincji przyłączył się klasztor w Drohobyczu (1698) z kresów wschodnich.

Na skutek rozbiorów i dekretów kasacyjnych w latach 1831-1864 wszystkie klasztory prowincji wielkopolskiej zostały zniesione, oprócz konwentu w Oborach, gdzie internowano zakonników z innych klasztorów, z przeznaczeniem tego miejsca aż do wymarcia ${ }^{3}$.

Artykuł powstał w oparciu o rękopis znajdujący się w Archiwum OO. Karmelitów w Krakowie ${ }^{4}$. Manuskrypt nie posiada strony tytułowej i jest bardzo uszkodzony. Zapisy są jednak czytelne. Uzupełnieniem podanego rękopisu jest zestawienie spisane przez przeora kartuskiego Jerzego Schwengla w jednym z rękopisów znajdujących się w zbiorach Archiwum Diecezjalnego w Pelplinie ${ }^{5}$. Oba rękopisy nie są wolne od błędów i dane w nich zawarte należy skonfrontować $\mathrm{z}$ innymi archiwaliami ${ }^{6}$. Całość uzupełniono na podstawie trzech nekrologów, w tym dwóch z Obór, jednego znajdującego się w zbiorach Archiwum w Krakowie ${ }^{7}$ i drugiego ze zbiorów Archiwum Diecezjalnego we Włocławku. Trzeci nekrolog ze zbiorów Archiwum we Włocławku9 pochodzi z klasztoru karmelitów w Gdańsku. Proweniencja tego nekrologu nie została podana, ale wskazują na to zapisy dotyczące

${ }^{3}$ B. Panek, W. Kolak, Karmelici, w: Encyklopedia katolicka, t. 8, Lublin 2000, kol. 808-812; W. Kolak, Katalog Archiwum Klasztoru OO. Karmelitów w Krakowie na Piasku, Kraków 1997, s. 12-29.

${ }^{4}$ Archiwum Klasztoru OO. Karmelitów w Krakowie „na Piasku” (dalej cyt.: AKK w Krakowie), rękopis AKKr 174/614. Zawiera on: Wykaz ojców i braci prowincji wielkopolskiej urodzonych w latach 1700-1774 oraz spis ojców i braci prowincji wielkopolskiej zmarlych w latach 1741-1784 (dalej cyt.: AKKr 174/614).

${ }^{5}$ Archiwum Diecezjalne w Pelplinie (dalej cyt.: ADP), Monastica, Kartuzy, sygn. Kart. 27 (dalej cyt.: Kart. 27). Ad historiam ecclesiaticam Poloniae apparatus collectus a G. Schwengel priore Cartusiae Paradisi BMV 1754, s. 407-416. Rękopis zawiera dane ojców i braci karmelitów prowincji wielkopolskiej, którzy złożyli profesję zakonną w latach 1688-1744. Rękopis zawiera tylko informacje o zakonnikach żyjących w roku 1744.

${ }^{6}$ Przykładem mogą być wypisy z ksiąg Libri Ordinatorum, które cytuję w przypisach. Różnią się one od danych podanych w części zasadniczej.

${ }^{7}$ AKK w Krakowie, rękopis AKKr 175/547. Album fratrum nostrorum a stabilita reformati[one] defunctorum in provincia Maioris Poloniae titulo Sanctissimi Sacramenti insignita [sic!] Ordinis Fratrum Beatissimae Virginis Mariae de Monte Carmelo strictioris observantiae authoritatae Venerabilis Capituli Provincialis in Conventu Oboriensi anno Domini 1775 die 11 et sequentibus mensis maii celebrati digestum (dalej cyt.: AKKr 175/547).

${ }^{8}$ Archiwum Diecezjalne we Włocławku (dalej cyt.: ADWł), sygn. Zakony 66 (dalej cyt.: Zak. 66). Album fratrum nostrorum a stabilita reformatione defunctorum in Provincia Majoris Poloniae titulo Sanctissimi Sacramenti Insignis Ordinis Fratrum B.V.Marie de Monte Carmelo strictioris observantiae authoritate Venerabilis Capituli Provincialis in Conventu Oboriensi anno Domini 1775 Die 11 et seqventibus mensis Maji celebrati digestum. W rękopisie brak paginacji.

${ }^{9}$ ADW1, sygn. Zakony 61 (dalej cyt.: Zak. 61). Catalogus defunctorum Fratrum, Tertiariorum lit[t]eras Confraternitis habentium totius Almae Provinciae Majoris Poloniae SSmi Sacramenti Fratrum B.V.Marie de Monte Carmelo S.O. Nec non Fundatorum, Fundatricum, Benefactorum, Benefactricum, Confratrum, Consororum, singulorum respective Conventuum supra expresae Provinciae anno 1740 compilatus. W księdze brak stron $\mathrm{z}$ wpisami od 10 do 18 sierpnia oraz od 16 do 31 grudnia. Strony „verso”, na których znajdują się wpisy zostały zapisane jako strony kolejne, gdyż 
zakonników przebywających w konwencie gdańskim, cystersów pelplińskich i kapłanów $^{10}$. W poniższym zestawieniu podano zapisy dotyczące karmelitów gdańskich odnotowane w nekrologu pelplińskim ${ }^{11}$. Nekrologi są mocno zniszczone. Spisano je w formie kalendarza, krakowski i gdański posiada każdy dzień na osobnej karcie, a włocławski na osobnej stronie. Rękopis włocławski nie posiada paginacji. Różnice pomiędzy podanymi nekrologami podaję w przypisach.

$\mathrm{W}$ opracowaniu podano imiona zakonnika ${ }^{12}$, które przyjął $\mathrm{w}$ zgromadzeniu oraz nazwisko i imię, które otrzymał na chrzcie. W sporej liczbie zapisów brak nazwiska. Wymienione zostały funkcje jakie pełnił w zakonie. Następnie podany jest rok lub data urodzenia, rok lub data i miejsce złożenia profesji zakonnej, rok lub data i miejsce otrzymania święceń kapłańskich ${ }^{13}$ oraz data i miejsce zgonu. Zapisy ułożono alfabetycznie według imion zakonnych. Na końcu znajduje się indeks alfabetyczny według nazwisk i imion z odsyłaczem $(\rightarrow)$ do imion używanych w zakonie. Zastosowano również odsyłacz $(\rightarrow)$ do innych form nazwiska i imion zakonnych użytych w tekście. W części zapisów podano rok urodzenia, rok złożenia profesji i rok otrzymania święceń kapłańskich wyliczony na podstawie danych podanych przy zgonie zakonnika. Mogą one się różnić od rzeczywistych danych i należy je skonfrontować z innymi źródłami. Rękopis Schwengla zawiera imiona zakonne, imię i nazwisko, datę urodzenia i złożenia profesji.

Tekst przygotowano zgodnie z Instrukcja wydawnicza dla źródet historycznych od XVI do połowy XIX wieku, red. Kazimierz Lepszy, Wrocław 1953. Pisownia imion, sprawowanych funkcji i pozostałego tekstu została ujednolicona według obecnej pisowni łacińskiej ${ }^{14}$. Nazwiska zapisano zgodnie z oryginałem. Ty-

obie znajdują się pod tą samą datą. W poniższym zestawieniu nie podaję cystersów pelplińskich ujętych w nekrologu.

${ }^{10} \mathrm{~W}$ nekrologu podani są cystersi z Pelplina, z którymi karmelici z Gdańska zawarli konfraternię. Konfraternia została podpisana 20 lutego $1720 \mathrm{w}$ Pelplinie przez opata pelplińskiego Tomasza Franciszka Czapskiego (ADP, Dipl. et epist., P 70). Potwierdzeniem tezy o pochodzeniu z Gdańska tego nekrologu są odnotowane zgony kapłanów z Archidiakonatu Pomorskiego: Adama Franciszka Goldmana prepozyta w Pucku (6 czerwca 1769), Jana Radoszewskiego prepozyta w Wejherowie (24 stycznia 1741), Piotra Trembeckiego prepozyta w Gniewie (25 kwietnia 1790). Po roku 1740 brak wpisów dotyczących cystersów pelplińskich. Nekrolog mógł zostać po spisaniu w roku 1740 przekazany do klasztoru w Kłodawie, gdzie przy zgonie Wielmożnego Kazimierza Słuckiego (3 grudnia 1759) dobroczyńcy klasztoru w Kłodawie wynika to jednoznacznie. Mógł też zostać zabrany do klasztoru w Kłodawie po kasacie klasztoru gdańskiego, co jest jednak wobec powyższego mniej prawdopodobne. Z klasztoru w Kłodawie został zabrany do Włocławka przez księży archiwistów: braci Stanisława i Zenona Chodyńskich.

${ }^{11}$ G. Kloskowski, Zakonnicy i zakonnice archidiakonatu pomorskiego w nekrologu cystersów pelplińskich z XVIII wieku, „Miesięcznik Archidiecezji Gdańskiej”, 52 (2008) nr 4-6, s. 333-337 (dalej cyt.: Zakonnicy). Z podanego artykułu nie udało się dopasować jednego zakonnika, brata laika Franciszka zmarłego 2 maja 1729 w klasztorze w Gdańsku.

${ }^{12}$ Określone w rękopisie jako nomina religionis oraz nomina saeculi.

${ }^{13} \mathrm{~W}$ przypadku braci zakonnych brak wpisu dotyczącego święceń kapłańskich.

${ }^{14}$ Stownik imion, opr. zbiorowe, Wrocław - Warszawa - Kraków 1991; J. Sondel, Stownik łacińsko-polski dla prawników i historyków, Kraków 2005; A. Jougan, Słownik kościelny łacińskopolski, Poznań 1958. 
tulatura zakonna i zawody została podana z małej litery, tak samo jak większość tekstu pisanego w oryginale dużą. Nie wprowadzono w niniejszym opracowaniu skrótów występujących w tekście, wszystkie starano się rozwinąć. W przypadku wątpliwości porównywano opracowanie z innymi wydawnictwami źródłowy$\mathrm{mi}^{15}$.

Opracowanie zawiera karmelitów prowincji wielkopolskiej od jej wyodrębnienia w 1686, do kasaty klasztorów w XIX wieku. Pojedyncze zapisy dotyczące zakonników z XIX i XX wieku wybiegają poza podane ramy czasowe, zostały jednak podane, gdyż opublikowano całość cytowanych rękopisów. W zestawieniu pominięto dobrodzeijów klasztorów karmelickich oraz konfratrów. Artykuł nie jest katalogiem zakonników, ukazuje tylko podstawowe dane biograficzne, które należałoby skonfrontować z innymi źródłami. Poniższe zestawienie nie jest również typowym opracowaniem źródła według obecnych standardów, jest natomiast kompilacją kilku źródeł. W ten sposób dane dotyczące poszczególnych zakonników są pełniejsze. Nie są to też zapewne wszyscy zakonnicy podanej prowincji, a kolejne rękopisy i publikacje ukażą nowe sylwetki ${ }^{16}$. W przypisach odesłano do pojedynczych biogramów zakonników zawartych w Polskim słowniku biograficznym ${ }^{17}$, Słowniku polskich teologów katolickich ${ }^{18}$ i Słowniku biograficznym Pomorza Nadwiślańskiego ${ }^{19}$. Pojedyncze informacje o zakonnikach zawarte są również w publikacjach dotyczących gimnazjum w Braniewie ${ }^{20}$ i Reszlu ${ }^{21}$ oraz

${ }^{15}$ A. Weiss, Raporty dziekanów o stanie kościołów diecezji poznańskiej w 1797 roku, Lublin 2010; S. Litak, Akta wizytacji generalnej diecezji Inflanckiej i Kurlandzkiej czyli Piltynskiej z 1761 roku, „Fontes Towarzystwa Naukowego w Toruniu”, 86 (1998).

${ }^{16}$ Przykładem są uzupełnienia o zakonnikach podanych w cytowanych archiwaliach i publikacjach.

${ }^{17}$ Polski Stownik Biograficzny (dalej cyt.: PSB), t. 1-46, Kraków 1935-2009.

${ }^{18}$ Słownik polskich teologów katolickich, t. 1-4, pod red. H. E. Wyczawskiego OFM, Warszawa 1981-1983 (dalej cyt.: SPTK).

${ }^{19}$ Stownik biograficzny Pomorza Nadwiślańskiego (dalej cyt.: SBPN), t. 1-4 oraz Suplement 1 i 2, red. S. Gierszewski, Z. Nowak, Gdańsk 1992-2002. Nie został ujęty w poniższym zestawieniu były karmelita, a następnie kapłan diecezjalny oraz działacz i bojownik o polskość: R. Szwoch, Łobodzki Józef Stanisław Wojciech (1796-1863), SBPN, t. 3, s. 110-111.

${ }^{20}$ G. Lühr, Die Schüler des Braunsberger Gymnasiums von 1694 bis 1776, [w:] Monumenta Historiae Warmiensis, Bd. 12, Braunsberg 1933 (dalej cyt.: Braniewo). Podane wypisy nie dotyczą zapewne wszystkich zakonników kształcących się w tym gimnazjum warmińskim. Niektórych osób podanych w tej publikacji nie udało się dopasować do poniższego zestawienia; Braniewo, nr 799, s. 41; Reszel II, nr 1759, s. 676 - Sierawski Jan. Syn Józefa i Joanny. Pochodził z Zembrowa na Warmii (Reszel: z Warszawy). Kształcił się w gimnazjum jezuickim w Reszlu od 1703. Od 21 maja $1704 \mathrm{w}$ wieku 21 lat rozpoczął naukę w klasie syntaksy w gimnazjum jezuickim w Braniewie. Wstąpił do zakonu karmelitów; Braniewo, nr 1720, s. 79 - Hanmann Andrzej. Syn Andrzeja i Barbary. Pochodził z Pieniężna. Od 3 września 1717 w wieku 14 lat rozpoczął naukę w klasie infimy w gimnazjum jezuickim w Braniewie. Wstąpił do zakonu karmelitów; Braniewo, nr 1967, s. 88 - Knoch Kazimierz. Syn Szymona. Pochodził z Braniewa. Od 2 września 1720 w wieku 9 lat rozpoczął naukę w klasie infimy w gimnazjum jezuickim w rodzinnym mieście. Wstąpił do zakonu karmelitów.

${ }^{21}$ G. Lühr, Die Schüler des Rösseler Gymnasiums nach dem Album der Marianischen Kongregation, w: „Zeitschrift für die Geschichte und Altertumskunde Ermlands”, Bd. 15, H. 44, Braunsberg 1905, s. 391-464, Bd. 15, H. 45, Braunsberg 1905, s. 579-704, Bd. 16, H. 46, Braunsberg 1906, 
opracowaniu ks. Wojciecha Zawadzkiego ${ }^{22}$. W przypisach podaję również wypisy z pojedynczych ksiąg Libri Ordinatorum sufraganów chełmińskich ${ }^{23}$, gnieźnień-

s. 158-312, Bd. 17, H. 49, Braunsberg 1910, s. 1-144; Bd. 18, H. 52, Braunsberg 1911, s. 138-167 (dalej cyt.: Reszel i kolejną część). Podane wypisy nie dotyczą zapewne wszystkich zakonników kształcących się w tym gimnazjum warmińskim. Niektórych osób podanych w tej publikacji nie udało się dopasować do poniższego zestawienia; Reszel I, nr 371, s. 447 - Krokau (Krakau) Albert. Od 1659 kształcił się w gimnazjum jezuickim w Reszlu. Wstąpił do zakonu karmelitów; Reszel II, nr 1018, s. 616 - Milkau Jerzy. Pochodził z Reszla. Od 1685 kształcił się w gimnazjum jezuickim w Reszlu. Wstąpił do zakonu karmelitów; Reszel II, nr 1177, s. 626; G. Kloskowski, Cystersi opactwa $w$ Pelplinie - artykuł przygotowany na konferencję «Biblioteki i skryptoria cysterskie na Pomorzu», która odbyła się 24 maja 2008 r. w Pelplinie. Został on opublikowany: G. Kloskowski, Sylwetki cystersów pelplińskich $w$ nekrologach $i$ kronice, „Studia Pelplińskie”, t. 44, 2011, s.240 - Iman Jan. Syn kuśnierza Tomasza i Anny. Został ochrzczony 29 stycznia 1674 w Dobrym Mieście. Od 1689 kształcił się w gimnazjum jezuickim w Reszlu od klasy syntetyki. Wstąpił do zakonu karmelitów. Jego brat Marcin w zak. Tomasz (1669-1735) był cystersem pelplińskim; Reszel III, nr 2098, s. 164 - Bonowski Antoni. Pochodził z Lidzbarka Warmińskiego. Od 1712 kształcił się w gimnazjum jezuickim w Reszlu od klasy gramatyki. Wstąpił do zakonu karmelitów; Reszel IV, nr 4033, s. 15 - Holtzki Jakub. Od 1751 kształcił się w gimnazjum jezuickim w Reszlu. Wstąpił do zakonu karmelitów.

${ }^{22}$ W. Zawadzki, Duchowieństwo katolickie oficjalatu pomezańskiego w latach 1525-1821, t. 2, Stownik, Elbląg 2009 (dalej cyt.: Zawadzki).

${ }^{23}$ ADP, sygn. A 41, Acta Capituli Culmensis, Ordinati ab Illmo et Rev. D.D. Thoma Bogoria Skotnicki ... episcopo Lycopoliensi suffraganeo offciali Culmensi generali 1686-1699. Ordinati ab Illmo Rev. D.D. Severino Szczuka ... episcopo Ioppensi suffraganeo, archdiacono, canonico Culmensi et Gnesnensi. 1705-1721. Confirmati 1697-1720 (dalej cyt.: ADP, A 41); sygn. A 16, Acta Capituli Culmensis, Liber Ordinatorum 1729-1749 (dalej cyt.: ADP, A 16); C 54a, Culmensia, Liber Ordinatorum 1750-1824. Liber Confirmatorum 1818-1822 (dalej cyt.: ADP, C 54a). W księdze C 54a brak święceń kapłanów z lat 1805-1818. Niektórych osób podanych w aktach tych sufraganów nie udało się dopasować do poniższego zestawienia; ADP, A 41, s. 8v - Andrzej od św. Marcelina. Członek konwentu w Bydgoszczy w 1692. Święcenia prezbiteratu otrzymał 20 grudnia $1692 \mathrm{w}$ katedrze w Chełmży z rąk sufragana chełmińskiego Tomasza Skotnickiego; ADP, A 41, k. 5, 5v i 6 Dawid od Narodzenia Pana. Członek konwentu w Oborach w 1691. Święcenia subdiakonatu otrzymał 10 marca 1691, diakonatu 31 marca 1691 i prezbiteratu 9 czerwca 1691 w katedrze w Chełmży z rąk sufragana chełmińskiego Tomasza Skotnickiego; ADP, A 41, s. 18v - Draszkiewicz Piotr. Członek konwentu w Bydgoszczy w 1697. Święcenia diakonatu otrzymał 21 grudnia 1697 w katedrze w Chełmży z rąk sufragana chełmińskiego Tomasza Skotnickiego; ADP, A 41, s. 27v - Erazm od św. Marii Magdaleny de’ Pazzi. Członek konwentu w Gdańsku w 1707. Święcenia subdiakonatu otrzymał 24 września 1707 w katedrze w Chełmży z rąk sufragana chełmińskiego Seweryna Szczuki; ADP, C 54a, s. 182, 183 i 184 - Glinowiecki Leon. Członek konwentu w Bydgoszczy w 1801. Tonsurę i niższe święcenia otrzymał 22 lutego 1801, święcenia subdiakonatu 28 lutego 1801, diakonatu 8 marca 1801 i prezbiteratu 15 marca 1801 w Chełmży. Szafarzem wszystkich święceń był sufragan chełmiński Iwon Onufry Rogowski; ADP, A 41, s. 27 - Hilary od św. Karola. Członek konwentu w Gdańsku w 1707. Tonsurę i niższe święcenia otrzymał 24 września 1707 w katedrze w Chełmży z rąk sufragana chełmińskiego Seweryna Szczuki; ADP, C 54a, s. 180a i 181 - Kraclewicz Maksymilian. Karmelita z konwentu w Gdańsku. Tonsurę i niższe święcenia otrzymał 24 października 1800, święcenia subdiakonatu 26 października 1800, diakonatu 28 października 1800 i prezbiteratu 2 listopada 1800 w Chełmży. Szafarzem wszystkich świeceń był sufragan chełmiński Iwon Onufry Rogowski; ADP, A 41, s. 15v i 18v - Kuciński (Kuczyński) Łukasz. Członek konwen- 
skich $^{24}$ i włocławskich ${ }^{25}$. Całość uzupełniają pojedyncze informacje z Tek Dworzaczka $^{26}$, Bibliografii Polskiej ${ }^{27}$, herbarzy, różnych opracowań i czasopism. Nie wszystkich zakonników z cytowanych opracowań i akt sufraganów można dopasować do obecnego opracowania ${ }^{28}$. Poniższe zestawienie jest wstępem do przygo-

tu w Bydgoszczy w latach 1696-1697. Święcenia subdiakonatu otrzymał 22 września 1696 i diakonatu 21 grudnia 1697 w katedrze w Chełmży z rąk sufragana chełmińskiego Tomasza Skotnickiego; ADP, C 54a, s. 165 i 166 - Niesiołowski Piotr od Św. Jana. Karmelita z konwentu w Gdańsku. Święcenia subdiakonatu otrzymał 13 lipca 1796, diakonatu 16 lipca 1796 i prezbiteratu 25 lipca 1796 w Chełmży z rąk sufragana chełmińskiego Iwona Onufrego Rogowskiego; ADP, C 54a, s. 180a i 181 - Parcheim Rudolf. Karmelita z konwentu w Gdańsku. Tonsurę i niższe święcenia oraz bierzmowanie otrzymał 24 października 1800, święcenia subdiakonatu 26 października 1800, diakonatu 28 października 1800 i prezbiteratu 2 listopada 1800 w Chełmży. Szafarzem wszystkich święceń był sufragan chełmiński Iwon Onufry Rogowski; ADP, C 54a, s. 179 - Potrikus Fulgenty. Karmelita z konwentu w Gdańsku. Święcenia diakonatu otrzymał 15 grudnia 1799 w Chełmży z rąk sufragana chełmińskiego Iwona Onufrego Rogowskiego; ADP, C 54a, s. 169 - Sobański Fabian. Karmelita z konwentu w Gdańsku. Tonsurę i niższe święcenia otrzymał 1 października 1797 w Chełmży z rąk sufragana chełmińskiego Iwona Onufrego Rogowskiego; ADP, C 54a, s. 180a i 181 - Spigahn Ildefons. Karmelita z konwentu w Gdańsku. Tonsurę i niższe święcenia otrzymał 24 października 1800, święcenia subdiakonatu 26 października 1800, diakonatu 28 października 1800 i prezbiteratu 2 listopada 1800 w Chełmży. Szafarzem wszystkich świeceń był sufragan chełmiński Iwon Onufry Rogowski; ADP, C 54a, s. 197 - Steynowicz Ambroży. Karmelita z konwentu w Gdańsku. Święcenia prezbiteratu otrzymał 19 czerwca 1803 w Chełmży z rąk sufragana chełmińskiego Iwona Onufrego Rogowskiego; ADP, C 54a, s. 197 - Woyciechowski Feliks. Karmelita z konwentu w Gdańsku. Święcenia prezbiteratu otrzymał 19 czerwca 1803 w Chełmży z rąk sufragana chełmińskiego Iwona Onufrego Rogowskiego.

${ }^{24}$ Archiwum Archidiecezjalne w Gnieźnie (dalej cyt.: AAG), sygn. ACap B 79, akta sufragana gnieźnieńskiego Franciszka Kraszkowskiego z lat 1720-1731 (dalej cyt.: AAG, ACap B 79); ACap B 80, akta sufragana gnieźnieńskiego Józefa Trzcińskiego z lat 1732-1737 (dalej cyt.: AAG, ACap B 80); ACon G II 4, akta sufragana gnieźnieńskiego Krzysztofa Dobińskiego z lat 1738-1762 (dalej cyt.: AAG, ACon G II 4); ACon G II 3, akta sufragana gnieźnieńskiego Ignacego Bardzińskiego z lat 1809-1813 i Józefa Gembartha z lat 1814-1821 (dalej cyt.: AAG, ACon G II 3). Są to wszystkie XVIII-wieczne (do 1821) akta sufraganów gnieźnieńskich zachowane w archiwum gnieźnieńskim. $\mathrm{Z}$ podanego okresu brak akt jedenastu sufraganów, zostały one prawdopodobnie zniszczone razem z aktami arcybiskupów gnieźnieńskich w czasie powstania warszawskiego w 1944. Z podanych akt sufraganów jednego zapisu nie udało się dopasować do poniższego zestawienia; AAG, ACon G II 4, s. 91v - Parzychowski Paweł. Święcenia subdiakonatu otrzymał 6 marca 1762 w kolegiacie św. Jerzego w Gnieźnie z rąk sufragana gnieźnieńskiego Krzysztofa Dobińskiego.

${ }^{25}$ ADWł, sygn. ABSWł. Adział. nr 10 (102), akta sufragana włocławskiego Jana Dembowskiego z lat 1760-1788 (dalej cyt.: ADWł, ABSWł 10).

${ }^{26}$ Wersja elektoniczna na płycie CD (dalej cyt.: TD).

${ }^{27}$ Wykorzystana została baza ze strony internetowej: http://www.estreicher.uj.edu.pl/baza estreichera/chronologia/

${ }^{28}$ W cytowanej Kroniczce jest wymienionych paru karmelitów, których imion brak w poniższym zestawieniu: Kroniczka, s. 14, 22, 189. O. Arnold od św. Antoniego. Prokurator klasztoru Bożego Ciała w Poznaniu i syndyk prowincji w latach 1703-1704 i 1714; Kroniczka, s. 34, 42, 50, 53, 75-76, 78, 80-81, 83, 89, 127-128 i 191. O. Bonawentura od św, Jakuba. Przebywał rezydencji przy kościele Najświętszej Krwi Pana Jezusa w Poznaniu w latach 1763-1767. Jego staraniem wymalowano i wyzłocono organy. W marcu 1767 odszedł do konwentu Bożego Ciała w Poznaniu. 
towania pełnego składu konwentu gdańskiego karmelitów trzewiczkowych w dobie potrydenckiej.

Serdecznie dziękuję Panu Szymonowi Sułeckiemu z Archiwum Ojców Karmelitów w Krakowie ${ }^{29}$, ks. prof. Witoldowi Kujawskiemu z Archiwum Diecezjalnego we Włocławku ${ }^{30}$ oraz ks. prof. Anastazemu Nadolnemu z Archiwum Diecezjalnego w Pelplinie ${ }^{31}$ za możliwość wykorzystania cytowanych rękopisów oraz wszelką pomoc merytoryczną. Za udzielenie informacji o składzie konwentu gdańskiego w latach 1817-1826 dziękuję panu Sławomirowi Kościelakowi ${ }^{32}$. Za korektę tekstu łacińskiego serdecznie dziękuję ks. Jerzemu K. Kalinowskiemu Dyrektorowi Archiwum Akt Dawnych Diecezji Toruńskiej. Składam również podziękowania Państwu Ewie i Józefowi Skwierawskim z Krakowa za wszelką pomoc okazaną podczas kwerendy.

Ponownie w rezydencji w marcu 1768; Kroniczka, s. 177 i 200. O. Feliks. W sierpniu 1769 lektor teologii i prawa kanonicznego, były gwardian. Prawdopodobnie franciszkanin reformat, o których powyżej w tekście, a nie karmelita. Wśród franciszkanów przełożeni byli gwardianami, a nie jak u pozostałych rodzin zakonnych przeorami; Kroniczka, s. 109, 122, 146 i 197. O. Filibert. Lektor św. teologii z konwentu Bożego Ciała w Poznaniu w 1767. Brak zakonnika o podanym imieniu w poniższym zestawieniu; Kroniczka, s. 19 i 189. Br. Franciszek, laik, przebywał w rezydencji przy kościele Najświętszej Krwi Pana Jezusa w Poznaniu w 1733; Kroniczka, s. 106, 110, 129 i 196. O. Urban od św. Doroty, lektor św. teologii, przebywał w konwencie Bożego Ciała w Poznaniu w 1731 i kaznodzieja tego konwentu w 1767; Nie udało się dopasować również podanych na s. 189 prowincjałów: Jana Rożańskiego (prowincjał w latach 1705-1709), Fulgentego Miedzińskiego (1709-1713 i od 1723), Idziego Palkiewicza (1715-1719) i Grzegorza Radwańskiego (1719-1723).

${ }^{29}$ Archiwum OO. Karmelitów w Krakowie „na Piasku”, ul. Karmelicka 19, 31-131 Kraków, tel. 12/632-67-52 w.143.

${ }^{30}$ Archiwum Diecezjalne we Włocławku, ul. Gdańska 2/4, 87-800 Włocławek, tel. 54/231-1112.

${ }^{31}$ Archiwum Diecezjalne w Pelplinie, ul. Bp. Dominika 11, 83-130 Pelplin, tel. 58/536-12-21 w.314.

32 Jednego brata zakonnego nie udało się dopasować do przygotowanego zestawienia. Wunder Antoni, w zakonie Józef. Urodził się w 1777 r. w Lidzbarku Warmińskim. Do zakonu karmelitów wstąpił 6 lipca $1810 \mathrm{r}$. Nie został wymieniony w wykazie z $1820 \mathrm{r}$. 


\section{Wykaz skrótów}

AAG - Archiwum Archidiecezjalne w Gnieźnie.

ADP - Archiwum Diecezjalne w Krakowie

ADW - Archiwum Diecezjalne w Pelplinie

AKKKr - Archiwum Klasztoru OO. Karmelitów w Krakowie

AKKr 174/614 - AKKKr, sygn. AKKr 174/614. Zawiera on: Wykaz ojców i braci prowincji wielkopolskiej urodzonych w latach 1700-1774 oraz spis ojców i braci prowincji wielkopolskiej zmarlych w latach 1741-1784

AKKr 175/547 - AKKKr, sygn. AKKr 175/547. Album fratrum nostrorum a stabilita reformati[one] defunctorum in provincia Maioris Poloniae titulo Sanctissimi Sacramenti insignita [sic!] Ordinis Fratrum Beatissimae Virginis Mariae de Monte Carmelo strictioris observantiae authoritatae Venerabilis Capituli Provincialis in Conventu Oboriensi anno Domini 1775 die 11 et sequentibus mensis maii celebrati digestum

ARP - Admodum Reverendus Pater - przewielebny ojciec (tytuł przełożonych i ważniejszych zakonników - kapłanów po święceniach).

Braniewo - G. Lühr, Die Schüler des Braunsberger Gymnasiums von 1694 bis 1776, [w:] Monumenta Historiae Warmiensis, Bd. 12, Braunsberg 1933.

Fr - Frater - brat (tytuł zakonników bez święceń).

Kart. 27 - ADP, Monastica, Kartuzy, sygn. Kart. 27. Ad historiam ecclesiaticam Poloniae apparatus collectus a G. Schwengel priore Cartusiae Paradisi BMV 1744, s. 407-416.

Kroniczka - Kroniczka rezydencji Karmelitów Trzewiczkowych w Poznaniu przy kościele Najświętszej Krwi Pana Jezusa na ul. Żydowskiej, oprac. J. Wiesiołowski, Poznań 2005.

nat. - nativitas - data urodzenia.

obit. - obitus - data (i miejsce) zgonu.

presb. - presbiteratus - data (i miejsce) otrzymania święceń kapłańskich (prezbiteratu).

prof. - professio - data (i miejsce) złożenia profesji zakonnej.

PSB - Polski stownik biograficzny, T. 1-46, Kraków 1935-2009.

Reszel - G. Lühr, Die Schüler des Rösseler Gymnasiums nach dem Album der Marianischen Kongregation, [w:] „Zeitschrift für die Geschichte und Altertumskunde Ermlands", Bd. 15, H. 44, Braunsberg 1905, s. 391-464, Bd. 15, H. 45, Braunsberg 1905, s. 579-704, Bd. 16, H. 46, Braunsberg 1906, s. 158-312, Bd.17, H. 49, Braunsberg 1910, s. 1-144; Bd. 18, H. 52, Braunsberg 1911, s. 138-167.

RP - Reverendus Pater - wielebny ojciec (tytuł zakonnika kapłana, po święceniach),

SBPN - Stownik biograficzny Pomorza Nadwiślańskiego, t. 1-4 oraz Suplement 1 i 2, red. S. Gierszewski i Z. Nowak, Gdańsk 1992-2002.

SPTK - Stownik polskich teologów katolickich, t. 1-4, pod red. H. E. Wyczawskiego OFM, Warszawa 1981-1983.

Zak. 61 - ADWł, sygn. Zakony 61. Catalogus defunctorum Fratrum, Tertiariorum lit[t]eras Confraternitis habentium totius Almae Provinciae Majoris Polo- 
niae SSmi Sacramenti Fratrum B.V.Marie de Monte Carmelo S.O. Nec non Fundatorum, Fundatricum, Benefactorum, Benefactricum, Confratrum, Consororum, singulorum respective Conventuum supra expresae Provinciae anno 1740 compilatus.

Zak. 66 - ADWł, sygn. Zakony 66. Album fratrum nostrorum a stabilita reformatione defunctorum in Provincia Majoris Poloniae titulo Sanctissimi Sacramenti Insignis Ordinis Fratrum B.V.Marie de Monte Carmelo strictioris observantiae authoritate Venerabilis Capituli Provincialis in Conventu Oboriensi anno Domini 1775 Die 11 et seqventibus mensis Maji celebrati digestum.

Zakonnicy - G. Kloskowski, Zakonnicy i zakonnice archidiakonatu pomorskiego w nekrologu cystersów pelplińskich z XVIII wieku, „Miesięcznik Archidiecezji Gdańskiej", 52: 2008, nr 4-6, s. 333-337.

Zawadzki - W. Zawadzki, Duchowieństwo katolickie oficjalatu pomezańskiego w latach 1525-1821, Tom II, Stownik, Elbląg 2009. 


\section{SKLAD OSOBOWY}

Adalbertus à S. Ignatio RP, Zbiiewski Ignatius ${ }^{33}$, nat. 02.05.1763, prof. 04.06.1780 Posnaniae, presb. 31.03.1788 Posnaniae.

Adamus à S. Casimiro Fr, Zukowski Casimirus ${ }^{34}$, per multos annos oeconomus in Zachcice Bidgostiensibus, nunc vero in Sztalmierz Oboriensi, nat. 17.06.1720, prof. 02.02.1756 Posnaniae, obit. 07.06.1783 Oboriis.

Adamus à S. Stanislao ARP, Zaremba Stanislaus ${ }^{35}$, ex prior sexennalis Lipiensis ac actualis subprior loci, nat. 19.11.1737, prof. 06.05.1755 Gedani, presb. 18.07.1761 Kcynae, obit. 23.10.1795 Plonscii.

Adamus à S. Teresia $\mathrm{Fr}^{36}$, nat. 1682, prof. 1719, obit. 16.06.1724 Kcynae.

Adauctus à S. Mathia RP, Hahn Mathias ${ }^{37}$, concionator Germanorum, nat. 27.02.1724, prof. 06.09.1741 Gedani, presb. 24.06.1748 Markovicae, obit. 30.05.1784 Lipiae.

Adrianus à S. Jacobo RP, Maszynski Jacobus ${ }^{38}$, aliquot annis concionator Polonorum, nat. 01.06.1729, prof. 19.09.1747 Gedani, presb. 19.08.1753 Varsaviae, obit. 16.12.1781 Kcynae.

Adrianus à S. Joanne Baptista ARP, Dryan Joannes ${ }^{39}$, emeritus, concionator insignis, ex prior Kcynensis et Posnaniensis, bis definitor provinciae, in prioratu Kcynensi interruptim complevit 12 annos, inchoato 13, nat. 05.08.1703, prof. 06.08.1719, obit. 08.07.1763 in Jastrowie sub manu medici, sepultus Kcynae.

Adrianus à S. Josepho Fr, Hoelle Josephus ${ }^{40}$, nat. 06.01.1741, prof. 07.09.1774 Gedani, obit. 30.03.1804 Bidgostiae.

Adrianus à S. Martino RP, Menia Martinus ${ }^{41}$, nat. 10.11.1764, prof. 18.01.1789 Gedani.

Aegidius à S. Andrea RP, Zagerman Andreas ${ }^{42}$, bis primitians, nat. 21.07.1753, prof. 13.09.1773 Gedani, presb. 06.10.1776 Klodaviae, obit. 27.06.1828 Gedani.

${ }^{33}$ AKKr 174/614, s. 16-17.

${ }^{34} \mathrm{AKKr} 174 / 614$, s. $22-23$ i 42: na s. 23 podana data zgonu 23 lipca 1783 r.; AKKr 175/547, s. 317 ; Zak. 66 .

${ }^{35}$ AKKr 174/614, s. 6-7; AKKr 175/547, s. 607: podana data zgonu 28 października 1795 r.; Zak. 66; Zak. 61, s. 287: podana data zgonu 22 października 1795 r.; ADP, C 54a, s. 29: jako członek konwentu w Gdańsku otrzymał 11 czerwca 1758 r. w Kartuzach tonsurę i niższe święcenia z rąk sufragana chełmińskiego Franciszka Fabiana Pląskowskiego.

${ }^{36} \mathrm{AKKr}$ 175/547, s. 337; Zak. 66; Zak. 61, s. 167 i 170: zapis zgonu z datą 19 czerwca 1724 przekreślony.

${ }^{37}$ AKKr 174/614, s. 4-5; Kart. 27, s. 413; AKKr 175/547, s. 301; Zak. 66; Zak. 61, s. 150.

${ }^{38}$ AKKr 174/614, s. 4-5 i 41; AKKr 175/547, s. 699: podana data zgonu 13 grudnia 1781; Zak. 66: podana druga data zgonu 29 stycznia 1782.

${ }^{39}$ AKKr 174/614, s. 36: podana data zgonu 7 lipca 1763; Kart. 27, s. 409; AKKr 175/547, s. 381; Zak. 66; Zak. 61, s. 188: podana data zgonu 7 lipca 1763.

${ }^{40}$ AKKr 174/614, s. 26-27; AKKr 175/547, s. 125; podana data zgonu 3 marca 1804; Zak. 66; Zak. 61, s. 89.

${ }^{41}$ AKKr 174/614, s. 18-19.

${ }^{42}$ AKKr 174/614, s. 12-13; AKKr 175/547, s. 359; Braniewo, nr 4909, s. 186: syn Andrzeja i Anny. Urodził się w Braniewie. Od 18 kwietnia 1763 kształcił się w klasie infimy w gimnazjum jezuickim w Braniewie; Informacje od p. Sławomira Kościelaka: przez niego podane nazwisko Je- 
Aegidius à S. Michaele RP ${ }^{43}$, Res. Capel., nat. 1727, prof. 1750, obit. 25.12.1770 Posnaniae.

Agabus à Matre Carmeli RP ${ }^{44}$, nat. 1666, prof. 1686, obit. 01.08.1700 Posnaniae.

Alanus à Praesentatine B.M.V. RP ${ }^{45}$, nat. 1678, prof. 1700, obit. 04.03.1725 Drohobiciis.

Alanus à S. Adamo RP, Dybysławski Adamus ${ }^{46}$, nat. 11.05.1752, prof. 06.02.1770 Posnaniae, presb. 25.05.1775 Gedani.

Alanus à S. Gerardo ARP, Pobłocki Joannes ${ }^{47}$, STL, jubilatus, ex definitor et ex secretarius provinciae, actualis prior loci, nat. 25.05.1710, prof. 25.09.1729, obit. 22.05.1756 Gedani.

Albertus (Adalbertus) à S. Francisco RP, Taube Franciscus ${ }^{48}$, organarius, choralis, bis primitians, seniculus, nat. 04.10.1691, prof. 16.10.1713, obit. 08.04.1771 Klodaviae.

Albertus à Passione Domini RP ${ }^{49}$, STL, nat. 1671, prof. 1697, obit. 04.05.1711 Varsaviae.

Albertus à Praesent. B.M.V. ARP ${ }^{50}$, prior loci, nat. 1637, prof. 1658, obit. 04.02.1677 Bidgostiae.

Albertus à Puero Jesu RP51, nat. 1671, prof. 1688, obit. 21.04.1736 Lipiae.

Albertus à S. Andrea $\mathrm{Fr}^{52}$, clericus novitius, nat. 1661, prof. 1679, obit. 23.06.1684 Posnaniae.

Albertus à S. Joanne Baptista RP ${ }^{53}$, nat. 1656, prof. 1678, obit. 04.08.1688 Oboriis.

Albertus à S. Joanne Evangelista RP ${ }^{54}$, nat. 1635, prof. 1657, obit. 17.11.1687 Bidgostiae.

germann. Do zakonu karmelitów wstąpił 20 sierpnia 1772. Podprzeor w Gdańsku w latach 18171826.

${ }^{43}$ AKKr 174/614, s. 37; AKKr 175/547, s. 723; Zak. 66; Kroniczka, s. 81, 82, 90, 109, 142, 151, 163, 171 i 195: przybył do rezydencji przy kościele Najświętszej Krwi Pana Jezusa w Poznaniu w 1766 z klasztoru w Markowicach. W rezydencji przebywał do 1769.

${ }^{44}$ AKKr 175/547, s. 429; Zak. 66; Zak. 61, s. 213.

${ }^{45}$ AKKr 175/547, s. 47 i 127: podany drugi zapis zgonu 24 stycznia 1721; Zak. 66: podany drugi zapis zgonu 24 stycznia 1721; Zak. 61, s. 63; ADP, A 41, s. 8 i 21: członek konwentu w Bydgoszczy w 1692 i w Oborach w 1699. Tonsurę i niższe święcenia otrzymał 20 grudnia 1692 i święcenia prezbiteratu 14 marca 1699 w katedrze w Chełmży z rąk sufragana chełmińskiego Tomasza Skotnickiego.

${ }^{46}$ AKKr 174/614, s. 12-13; ADP, C 54a, s. 124: jako członek konwentu w Gdańsku otrzymał 21 maja 1775 w kościele św. Wojciecha pod Gdańskiem święcenia prezbiteratu z rąk sufragana chełmińskiego Franciszka Fabiana Pląskowskiego.

${ }^{47}$ AKKr 174/614, s. 34; Kart. 27, s. 410; AKKr 175/547 s. 285; Zak. 66; Zak. 61, s. 142; Zakonnicy, s. 334.

${ }^{48}$ AKKr 174/614, s. 38; Kart. 27, s. 408; AKKr 175/547 s. 197; Zak. 66; Zak. 61, s. 98.

${ }^{49}$ AKKr 175/547, s. 249; Zak. 66; Zak. 61, s. 124.

${ }^{50} \mathrm{AKKr}$ 175/547, s. 69; Zak. 66; Zak. 61, s. 35.

${ }^{51}$ AKKr 175/547, s. 223; Zak. 66; Zak. 61, s. 111; ADP, A 41, s. 18v i 22v: członek konwentu w Bydgoszczy w latach 1697-1698. Święcenia diakonatu otrzymał 21 grudnia 1697 i prezbiteratu 24 maja 1698 w katedrze w Chełmży z rąk sufragana chełmińskiego Tomasza Skotnickiego.

${ }^{52}$ AKKr 175/547, s. 351; Zak. 66; Zak. 61, s. 178: podana data zgonu 27 czerwca 1684.

${ }^{53}$ AKKr 175/547, s. 435; Zak. 66; Zak. 61, s. 215: podana data zgonu 3 sierpnia 1688.

${ }^{54}$ AKKr 175/547, s. 647; Zak. 66; Zak. 61, s. 313. 
Albertus à S. Joanne RP, Tempski Joannes ${ }^{55}$, capellanus et subprior Trutoviensis, nat. 19.12.1771, prof. 1794, obit. 11.07.1824 in villa Ostrowite.

Albertus à S. Marco Juvenis RP ${ }^{56}$, obit. 02.04.1687 Gedani.

Albertus à S. Silvestro RP ${ }^{57}$, nat. 1662, prof. 1680, obit. 10.01.1687 Gedani.

Albertus à S. Spiritu Fr ${ }^{58}$, nat. 1635, prof. 1655, obit. 26.06.1710 Varsaviae.

Albertus à S. Stanislao ARP ${ }^{59}$, ex prior Varsaviensis, ubi primus acceptavit strictiorem observantiam, tandem seniculus, obit 31.03.1709 Posnaniae.

Albertus à SS. Joanne \& Paulo RP, Ruchniewicz Martinus ${ }^{60}$, concionator Polonorum, ex subprior Oboriensis, ex lector theologiae moralis, nat. 13.11.1719, prof. 26.06.1739 Gedani, presb. 30.06.1743 Posnaniae, obit. 07.09.1778 Posnaniae in Residencia.

Albertus à SS. Joanne $\mathrm{Fr}^{61}$, nat. 1662, prof. 1683, obit. 25.02.1687 Posnaniae.

Albertus Janicki RP ${ }^{62}$, olim professor clericorum Varsaviae, vicarius in Chorzele, nat. 1839, obit. 19.02.1879 Chorzele.

Albinus à S. Adalberto $\rightarrow$ Albinus à S. Gregorio

Albinus à S. Caecilia Fr, Toczynski Franciscus ${ }^{63}$, tibicen bene meritus, nat. 19.09.1724, prof. 07.07.1749 Posnaniae, obit. 16.03.1779 Markovicae.

Albinus à S. Casimiro ARP, Wołęcki Josephus ${ }^{64}$, STL, ex provincialis, ex definitor, ex prior Trutoviensis, nat. 22.03.1722, prof. 07.03.1741 Gedani, presb. 17.04.1746 Varsaviae, obit. 24.01.1778 in villa Rakowo, sepultus Trutoviae.

Albinus à S. Euphrasia Fr ${ }^{65}$, nat. 1660, prof. 1684, obit. 23.12.1708 Posnaniae.

Albinus à S. Gregorio Fr, Szpotanski Petrus ${ }^{66}$, sartor, nat. 16.07.1698, prof. 17.11.1727, obit. 16.02.1748 Klodaviae.

${ }^{55}$ AKKr 174/614, s. 20; Zak. 66.

${ }^{56}$ AKKr 175/547, s. 185; Zak. 66; Zak. 61, s. 92.

${ }^{57} \mathrm{AKKr}$ 175/547, s. 19 i 735: drugi zapis zgonu 31 grudnia 1688; Zak. 66: drugi zapis zgonu 31 grudnia 1688; Zak. 61, s. 10.

${ }^{58}$ AKKr 175/547, s. 357 i 533: podana druga data zgonu 21 września 1708; Zak. 66: podana druga data zgonu 21 września 1708; Zak. 61, s. 176 i 255: podana data zgonu 25 czerwca, rok nie został podany oraz 21 września 1708 .

${ }^{59} \mathrm{AKKr} 175 / 547$, s. 181; Zak. 66; Zak. 61, s. 90.

${ }^{60} \mathrm{AKKr} 174 / 614$, s. $2-3$ i 40; Kart. 27, s. 412; AKKr 175/547, s. 505; Zak. 66: podana data zgonu 8 września 1778; Zak. 61, s. 241 i 242: zapis z datą zgonu 6 września 1778 przekreślony.

${ }^{61}$ AKKr 175/547, s. 111; Zak. 66; Zak. 61, s. 56.

${ }^{62}$ AKKr 175/547, s. 99.

${ }^{63}$ AKKr 174/614, s. 22-23 i 40; AKKr 175/547, s. 151; Zak. 66: podana data zgonu 26 marca 1779; Zak. 61, s. 75.

${ }^{64}$ AKKr 174/614, s. 4-5 i 40: na s. 4-5 podana data zgonu 11 stycznia 1778; Kart. 27, s. 413: podana data urodzenia 21 marca 1722; AKKr 175/547, s. 43 i 47: na s. 43 podana data zgonu 22 stycznia 1778; Zak. 66; Zak. 61, s. 24 i 27: zapis zgonu z datą 27 stycznia 1778 przekreślony; Kroniczka, s. 80-82, 87-90, 109, 124, 126, 131, 134, 152-153, 156-157 i 195: prowincjał w latach 17671768.

${ }^{65} \mathrm{AKKr} 175 / 547$, s. 719; Zak. 66.

${ }^{66}$ AKKr 174/614, s. 31; Kart. 27, s. 415; AKKr 175/547, s. 73; Zak. 66; Zak. 61, s. 37: podana data zgonu 6 lutego 1748 oraz imiona zakonne Albinus à S. Adalberto. 
Albinus à S. Ludovico ARP, Woyciechowski Ludovicus ${ }^{67}$, ex prior Posnaniensis, Kcynensis et Trutoviensis, nat. 25.08.1750, prof. 30.09.1769 Posnaniae, presb. 29.09.1774 Posnaniae, obit. 24.04.1817 Posnaniae.

Albinus Pepłowski RP ${ }^{68}$, ex procurator Trutoviensis, nat. 1772, prof. 1818, presb. 1819, obit. 19.06.1834 Varsaviae.

Alexander à S. Andrea Corsino RP ${ }^{69}$, nat. 1650, prof. 1670, obit. 03.11.1689 Posnaniae.

Alexander à S. Andrea Corsino RP ${ }^{70}$, nat. 1678, prof. 1697, obit. 28.09.1709 Posnaniae.

Alexander à S. Antonio RP, Bialk Antoniuss ${ }^{71}$, nat. 13.06.1765, prof. 13.08.1784 Gedani.

Alexander à S. Benedicto ARP, Francose Benedictus ${ }^{72}$, ex prior Varsaviensis et loci, nat. 24.02.1692, prof. 12.03.1716, obit. 15.12.1761 Oboriis.

Alexander à S. Joanne Fr, Kraca Joannes ${ }^{73}$, seniculus, terminarius, bene commendatus et exemplaris, nat. 26.07.1734, prof. 01.08.1767 Gedani, obit. 18.05.1808 Gedani.

Alexander à S. Josepho RP ${ }^{74}$, nat. 1727, prof. 1746, obit. 09.11.1771 Klodaviae.

Alexander ab Inventione S. Crucis RP ${ }^{75}$, nat. 1652, prof. 1668, obit. 13.02.1692 Posnaniae.

Alexius à S. Andrea Wasilowski $\mathrm{ARP}^{76}$, ex prior Lipiensis et Plonscensis, subprior Trutoviensis, nat. 1791, prof. 1823, presb. 1827, obit. 08.03.1854 Rypin, sepultus Trutoviae.

Alexius à S. Antonio ARP, Wolffen Antonius ${ }^{77}$, STL, ex provincialis, ex prior Gedanensis et Markovicensis, ex definitor, actualis custos provinciae, nat. 01.10.1754, prof. 10.03.1772 Gedani, presb. 19.04.1778 Posnaniae, obit. 21.10.1807 Kcynae.

Alexius à S. Eliseo $\mathrm{Fr}^{78}$, nat. 1637, prof. 1659, obit. 29.09.1677 Bidgostiae.

Alexius à S. Joanne Evangelista Fr $^{79}$, nat. 1656, prof. 1676, obit. 19.08.1714 Gedani.

Alexius à S. Rocho $\mathrm{RP}^{80}$, nat. 1709, prof. 1727, obit. 02.10.1735 Varsaviae.

${ }^{67}$ AKKr 174/614, s. 12-13; AKKr 175/547, s. 229: podane, że zmarł w rezydencji Krwi Chrystusa; Zak. 66.

${ }^{68}$ AKKr 175/547, s. 343; Zak. 66.

${ }^{69}$ AKKr 175/547, s. 619; Zak. 66; Zak. 61, s. 299.

${ }^{70}$ AKKr 175/547, s. 547; Zak. 66; Zak. 61, s. 262: podana data zgonu 27 września 1709.

${ }^{71} \mathrm{AKKr} 174 / 614$, s. $18-19$.

${ }^{72}$ AKKr 174/614, s. 35; Kart. 27, s. 408; AKKr 175/547, s. 703; Zak. 66; Zak. 61, s. 340.

${ }^{73}$ AKKr 174/614, s. 24-25; AKKr 175/547, s. 277; Zak. 61, s. 25: podana data zgonu 25 stycznia 1808; Zakonnicy, s. 336: podana informacja, że zmarł w Pogódkach koło Starogardu Gdańskiego w roku 1808.

${ }^{74}$ AKKr 174/614, s. 38: podana data zgonu 7 lipca 1771; AKKr 175/547, s. 631; Zak. 66; Zak. 61, s. 305 i 188: podana data zgonu 7 lipca 1771 w kaplicy w Wysokiej, pochowany w Kłodawie.

${ }^{75} \mathrm{AKKr} 175 / 547$, s. 87; Zak. 66; Zak. 61, s. 44.

${ }^{76}$ AKKr 175/547, s. 135; Zak. 66.

${ }^{77}$ AKKr 174/614, s. 12-13; AKKr 175/547, s. 593; Zak. 66; Zak. 61, s. 286.

${ }^{78} \mathrm{AKKr}$ 175/547, s. 549; Zak. 66; Zak. 61, s. 264.

${ }^{79}$ AKKr 175/547, s. 465; Zak. 66; Zak. 61, s. 223.

${ }^{80} \mathrm{AKKr}$ 175/547, s. 617; Zak. 66; Zak. 61, s. 129 i 298: podane daty zgonu 9 maja i 2 listopada 1735. 
Alexius à Visitatione B.M.V. RP, Braus Mathias ${ }^{81}$, ex concionator Polononorum plurimorum annorum, ex subprior Kcynensis et Klodaviensis, nat. 16.02.1720, prof. 05.07.1736, presb. 1745, obit. 19.01.1771 Posnaniae, in capella Sanguinis Christi.

Alexius Szumakowski (Szymakow) Fr ${ }^{82}$, clericus, nat. 1776, obit. 24.09.1809 Gedani.

Aloysius à S. Antonio Bęczkowski RP ${ }^{83}$, concionator, nat. 1820, prof. 1843, presb. 1846, obit. 17.03.1850 Varsaviae.

Aloysius à S. Joanne Maczul RP ${ }^{84}$, absolutis 27 missae Sacrificiis vitam temporalem finivit, nat. 1810, prof. 1830, obit. 25.12.1840 Vąsosiae.

Aloysius à S. Josepho RP, Swieykowski Josephus ${ }^{85}$, nat. 16.08.1721, prof. 27.07.1758 Posnaniae, presb. 24.06.1762 Kcynae, obit. 01.03.1794 Varsaviae.

Aloysius à S. Josepho Siennicki RP ${ }^{86}$, nat. 1827, obit. 01.07.1877 Oboriis.

Aloysius à S. Petro ARP, Sobierzynski Valentinus ${ }^{87}$, variis in conventibus ex subprior, ex prior Plonscensis, actualis prior Drohobicensis, expiravit in itinere eundo ad capitulum provinciale, nat. 10.02.1708, prof. 22.02.1728, obit. 06.05.1754 Thorunii, apud R.P. Bernardinos.

\section{Aloysius à SS. Petro \& Paulo $\rightarrow$ Aloysius à S. Petro}

Aloysius Maciejczak Fr $^{88}$, nat. 1810, prof. 1845, obit. 11.11.1864 Lipiae.

Alphonsus à S. Gregorio RP, Charazniewicz Andreas ${ }^{89}$, ex concionator Polonorum, ex subprior Kcynae, subprior loci, nat. 18.11.1710, prof. 19.03.1727, obit. 23.04.1752 Drohobiciis.

Alphonsus à S. Joanne $\mathrm{Fr}^{90}$, musicus, nat. 1694, prof. 1722, obit. 30.04.1732 Kcynae.

Alphonsus à S. Joanne RP, Ceynoff Joannes ${ }^{91}$, subprior loci, nat. 28.06.1767, prof. 25.10.1784 Gedani, obit. 02.03.1820 Trutoviae.

${ }^{81}$ AKKr 174/614, s. 37: podana data zgonu 19 stycznia 1770; Kart. 27, s. 412; AKKr 175/547, s. 37; Zak. 66; Zak. 61, s. 19; Kroniczka, s. 185 i 202: przybył do rezydencji przy kościele Najświętszej Krwi Pana Jazusa w Poznaniu w grudniu 1769 z klasztoru w Kcyni.

${ }^{82}$ Zak. 61, s. 259; Zakonnicy, s. 336.

${ }^{83}$ AKKr 175/547, s. 153; Zak. 66.

${ }^{84}$ AKKr 175/547, s. 723; Zak. 66.

${ }^{85}$ AKKr 174/614, s. 6-7; AKKr 175/547, s. 121; Zak. 66; Zak. 61, s. 60; ADWł, ABSWł 10, s. 12: członek konwentu w Bydgoszczy w 1761. Tonsurę i niższe święcenia otrzymał 28 października 1761 w kościele klarysek w Bydgoszczy z rąk sufragana włocławskiego Jana Dembowskiego; AAG, ACon G II 4, s. 91v: święcenia subdiakonatu otrzymał 6 marca 1762 w kolegiacie Św. Jerzego w Gnieźnie z rąk sufragana gnieźnieńskiego Krzysztofa Dobińskiego.

${ }^{86} \mathrm{AKKr} 175 / 547$, s. 367.

${ }^{87}$ AKKr 174/614, s. 33; Kart. 27, s. 410; AKKr 175/547, s. 253: podane imiona zakonne Aloysius à SS. Petro \& Paulo; Zak. 66: podane imiona zakonne Aloysius à SS. Petro \& Paulo; Zak. 61, s. 126

${ }^{88}$ AKKr 175/547, s. 635; Zak. 66.

${ }^{89} \mathrm{AKKr} 174 / 614$, s. 33: podana data zgonu 20 kwietnia 1752; Kart. 27, s. 410; AKKr 175/547, s. 227; Zak. 66; Zak. 61, s. 110: podana data zgonu 20 kwietnia 1752.

${ }^{90} \mathrm{AKKr} 175 / 547$, s. 241; Zak. 66; Zak. 61, s. 120.

${ }^{91}$ AKKr 174/614, s. 18-19; Zak. 66; AKKr 175/547, s. 125 i 157: podane daty zgonu 3 i 19 marca 1820. 
Alphonsus à S. Mathaeo ARP, Julicki Mathaeus ${ }^{92}$, STL, concionator Polonorum, ex professor rhetorices, actualis secretarius provinciae, nat. 02.09.1736, prof. 01.06.1753 Gedani, presb. 29.09.1759 Varsaviae, obit. 06.12.1782 Bidgostiae.

Alphonsus Giercuszkiewicz ARP ${ }^{93}$, ex prior Trembovlensis et Leopoliensis, nocte in Vigilia Nativitatis Domini repentina improvisaque morte e vita migravit, nat. 1850, obit. 24.12.1917 Leopoli.

Amandus à $\mathrm{S}$. Andrea à Annis $\rightarrow$ Eadmundus à $\mathrm{S}$. Andrea à Annis

Amandus à S. Benedicto Gółkowski RP ${ }^{94}$, actualis vicarius parochiae Nativitatis Viriginis Mariae, nat. 1842, prof. 1859, presb. 1867, obit. 18.08.1869 Varsaviae.

Amandus à S. Ignatio RP ${ }^{95}$, concionator Polonorum et festivalis, nat. 1724, prof. 1746, obit. 07.10.1771 Klodaviae.

Amandus à S. Mathia RP, Schultz Mathias ${ }^{96}$, nat. 23.02.1753, prof. 17.04.1772 Posnaniae, presb. 07.04.1776 Varsaviae, obit. 19.10.1811 Bydgostiae.

Ambrosius à S. Francisco RP, Cylkowski Franciscus ${ }^{97}$, organarius, choralis, 9 annis concionator Polonorum, exorcista commendatus, nat. 07.10.1718, prof. 17.10.1743, obit. 29.07.1772 Markovicae.

Ambrosius à S. Joanne à Cruce RP ${ }^{98}$, nat. 1690, prof. 1708, obit. 18.02.1730 Drohobiciis.

Ambrosius à S. Joanne ARP, Modrzynski Joannes ${ }^{99}$, prior loci, nat. 23.10.1752, prof. 30.08.1773 Posnaniae, presb. 15.08.1777 Varsaviae, obit. 21.01.1790 Plonscii.

Ambrosius à S. Joanne Ostrowski RP ${ }^{100}$, pluribus annis subprior Trutoviensis, nat. 1811, prof. 1835, presb. 1840, obit. 19.05.1863 Varsaviae.

Ananias à S. Severino ARP, Molsdrroff Severinus ${ }^{101}$, ex prior Plonscensis, nat. 1751, prof. 06.02.1770 Posnaniae, presb. 28.04.1776 Klodaviae, obit. 27.03.1814 Plonscii.

Anastasius à S. Adalberto ARP, Ciekalski Adalbertus ${ }^{102}$, ex prior Bidgostiensis, definitor, nat. 13.04.1752, prof. 20.06.1770 Gedani, presb. 07.05.1775 Posnaniae, obit. 27.01.1814 Bidgostiae.

Anastasius à S. Agnete RP ${ }^{103}$, nat. 1646, prof. 1665, obit. 04.03.1692 Posnaniae.

${ }^{92}$ AKKr 174/614, s. 6-7 i 42; AKKr 175/547, s. 685; Zak. 66.

${ }^{93}$ AKKr 175/547, s. 721.

${ }^{94}$ AKKr 175/547, s. 463.

${ }^{95}$ AKKr 174/614, s. 38: podana data zgonu 5 października 1771; AKKr 175/547, s. 565; Zak. 66; Zak. 61, s. 270: podana data zgonu 5 października 1771.

${ }^{96}$ AKKr 174/614, s. 12-13; AKKr 175/547, s. 589; Zak. 66.

${ }^{97}$ AKKr 174/614, s. 38; Kart. 27, s. 414; AKKr 175/547, s. 423; Zak. 66; Zak. 61, s. 210.

${ }^{98}$ AKKr 175/547, s. 97; Zak. 66; Zak. 61, s. 49; G. Kloskowski, Sylwetki ..., s.244: syn Michała Topolskiego i Anny Jurgiewicz. Urodził się w Gdańsku. Jego brat Franciszek, w zak. Augustyn (1688-1746) to cysters pelpliński.

${ }^{99}$ AKKr 174/614, s. 12-13; AKKr 175/547, s. 41; Zak. 66; Zak. 61, s. 21; ADP, C 54a, s. 124 i 125: członek konwentu w Gdańsku w 1775. Tonsurę i niższe święcenia otrzymał 25 maja 1775, święcenia subdiakonatu 10 czerwca 1775 w kościele św. Wojciecha pod Gdańskiem i diakonatu 2 lipca 1775 w Oliwie z rąk sufragana chełmińskiego Franciszka Fabiana Pląskowskiego.

${ }^{100} \mathrm{AKKr} 175 / 547$, s. 279; Zak. 66.

${ }^{101}$ AKKr 174/614, s. 12-13; AKKr 175/547, s. 173; Zak. 66.

${ }_{102}$ AKKr 174/614, s. 12-13; AKKr 175/547, s. 53; Zak. 66.

${ }^{103}$ AKKr 175/547, s. 127; Zak. 66; Zak. 61, s. 63 i 142: podana druga data zgonu 22 maja 1692. 
Anastasius à S. Andrea Corsino ARP ${ }^{104}$, ex prior Posnaniensis, nat. 1637, prof. 1658, obit. 13.01.1688 Posnaniae.

Anastasius à S. Andrea RP ${ }^{105}$, obit. 08.06.1710 Posnaniae.

Anastasius à S. Ignatio Fr, Gniazdowski Ignatius ${ }^{106}$, nat. 02.09.1753, prof. 13.12.1778 Gedani, obit. 06.12.1812 Markovicae.

Anastasius à S. Michaele Kijewski $\mathrm{ARP}^{107}$, ex prior Wąsosesnisis, Lipiensis, Guloviensis, ex definitor provinciae, ac actualis concionator Klodaviensis, nat. 1802, prof. 1826, presb. 1828, sub manu medici obit. 10.06.1853 Varsaviae, sepultus ibidem in caemeterio Powązki.

Anastasius à S. Thoma Fr, Stroinski Thomas ${ }^{108}$, sartor, nat. 21.12.1730, prof. 04.06.1760 Gedani, obit. 25.07.1777 Trutoviae.

Anastasius à S. Timotheo RP ${ }^{109}$, concionator Polonorum, nat. 1670, prof. 1689, obit. 25.03.1702 Bidgostiae.

Anastasius Jadachowski RP ${ }^{110}$, nat. 1834, obit. 20.05.1877.

Anastius (Anastasius) à S. Brocardo ARP, Bretschneider Michael ${ }^{111}$, STL, jubilatus, bis definitor ac praeses capituli Gedanensis, ex prior bis Varsaviensis et bis Oboriensis, 6 annis praesidens oratorii; erga B.V.Mariam singulariter devotus, nat. 09.09.1692, prof. 05.09.1714, obit. 07.04.1764 Bidgostiae.

Anastius (Anastasius) à S. Joanne Nepomuceno RP, Komierowski Ignatius ${ }^{112}$, nat. 06.01.1720, prof. 20.08.1736 Gedani, presb. 24.06.1742 Posnaniae, in. Min. Pol. Antiquista.

Andreas à Commemoratus B.M.V. RP ${ }^{113}$, nat. 1652, prof. 1672, obit. 17.01.1689 Bidgostiae.

Andreas à Conversione S. Pauli RP ${ }^{114}$, concionator Polonorum, nat. 1708, prof. 1726, obit. 31.07.1738 Bidgostiae.

${ }^{104}$ AKKr 175/547, s. 25 i 319; Zak. 66: w obu rękopisach drugi zapis z datą 8 czerwca 1688; Zak. 61, s. 13 i 22: podana data zgonu 22 stycznia 1688.

${ }^{105}$ Zak. 61, s. 159.

${ }^{106}$ AKKr 174/614, s. 26-27; Zak. 66.

${ }^{107}$ AKKr 175/547, s. 323; Zak. 66.

${ }^{108}$ AKKr 174/614, s. 24-25 i 40; AKKr 175/547, s. 415; Zak. 66; Zak. 61, s. 206.

${ }^{109}$ AKKr 175/547, s. 169; Zak. 66; Zak. 61, s. 84: podana data zgonu 25 marca 1700 Pakość, jako kaznodzieja z Bydgoszczy.

${ }^{110} \mathrm{AKKr} 175 / 547$, s. 281

${ }^{111}$ AKKr 174/614, s. 36; Kart. 27, s. 408; AKKr 175/547, s. 195; Zak. 66; Zak. 61, s. 97; Reszel II, nr 1963, s. 695: pochodził z Lidzbarka Warmińskiego. Od 1708 kształcił się w gimnazjum jezuickim w Reszlu; Kroniczka, s. VI, 1, 23, 112 i 188: lektor św. teologii w klasztorze Bożego Ciała w Poznaniu w 1731. Prezydent rezydencji przy kościele Najświętsze Krwi Pana Jezusa w latach 1751-1757, potem w klasztorze w Bydgoszczy.

${ }^{112}$ AKKr 174/614, s. 2-3. Kart. 27, s. 412: podana data urodzenia 28 stycznia 1720; T. Żychliński, Ztota księga szlachty polskiej, Poznań 1888, T. 10, s. 190: syn Andrzeja i Ewy Lubstowskiej; M. Borkowska OSB, Leksykon zakonnic polskich epoki przedrozbiorowej, Tom I - Polska Zachodnia i Północna, Warszawa 2004, s. 149: jego siostra Franciszka, w zak. Agata (1715-1783) to klaryska bydgoska. Brat Kazimierz (1724-1776) był również karmelitą trzewiczkowym i prowincjałem; Kroniczka, s. 28 i 190: przebywał w rezydencji przy kościele Najświętszej Krwi Pana Jezusa w Poznaniu od maja 1763.

${ }^{113}$ AKKr 175/547, s. 33; Zak. 66; Zak. 61, s. 17.

${ }^{114}$ AKKr 175/547, s. 427; Zak. 66; Zak. 61, s. 212. 
Andreas à Purificatione B.M.V. $\mathrm{Fr}^{115}$, scrinifaber, nat. 1672, prof. 1701, obit. 17.03.1720 Posnaniae.

Andreas à Purificat B.M.V. RP ${ }^{116}$, syndicus provinciae, nat. 1644, prof. 1666, obit. 12.05.1687 Bidgostiae.

Andreas à S. Alexandro Fr, Zarzycki Martinus ${ }^{117}$, nat. 05.11.1713, prof. 28.11.1741, obit. 11.01.1773 Posnaniae.

Andreas à S. Alexandro RP ${ }^{118}$, actualis concionator Polonorum Bidgostiensis, obiit apud consanguineos suos in palatinatu Kujaviensi, nat. 1733, prof. 1755, obit. 11.05.1771 Markovicae.

Andreas à S. Cruce $\mathrm{Fr}^{119}$, nat. 1689, prof. 1705, obit. 06.11.1734 Posnaniae.

Andreas à S. Francisco ARP, Ratnan (Ratnoff) Franciscus ${ }^{120}$, ex prior Lipiensis, prior loci, nat. 1770, prof. 1790, presb. 1795, obit. 22.05.1817 Kcynae.

Andreas à S. Francisco $\mathrm{Fr}^{121}$, diaconus, nat. 1646, prof. 1666, obit. 28.11.1680 Posnaniae.

Andreas à S. Joanne Fr ${ }^{122}$, nat. 1691, prof. 1720, obit. 05.03.1740 Gedani.

Andreas à S. Joanne RP, Budyq Joanne ${ }^{123}$, organarius, vocalista, concionator Germanorum, lector philosophiae, nat. 15.09.1752, prof. 24.11.1777 Gedani, presb. 09.08.1778 Gedani, obit. 06.02.1789 Gedani.

Andreas à S. Michaele Fr, Friess Michael ${ }^{124}$, sutor, nat. 29.01.1744, prof. 22.11.1774 Gedani, obit. 30.10.1814 Posnaniae.

Andreas à S. Michaele Fr, Horodecki Michael ${ }^{125}$, nat. 1734, prof. 25.07.1754 Gedani, obit. 04.03.1792 Varsaviae.

Andreas à S. Petro $\mathrm{Fr}^{126}$, diaconus, nat. 1656, prof. 1673, obit. 18.07.1680 Posnaniae.

Andreas à S. Spiritu ex Anti. (Jurisperitus) ARP, Sczerbic Antonius ${ }^{127}$, seniculus, ex prior ac praesidens in nova fundatione Trutoviensi, nat. 1670, prof. 1690, obit. 22.08.1760 Oboriis.

${ }^{115}$ AKKr 175/547, s. 153; Zak. 66; Zak. 61, s. 76.

${ }^{116}$ AKKr 175/547, s. 265; Zak. 66; Zak. 61, s. 132.

${ }^{117}$ AKKr 174/614, s. 38: podana błędnie data zgonu 9 stycznia 1733; Kart. 27, s. 415; AKKr 175/547, s. 21; Zak. 66; Zak. 61, s. 9 i 11: podana data zgonu 9 stycznia 1773, a błędnie data zgonu 11 stycznia 1733; Kroniczka, s. 59, 64, 118, 158 i 193: przebywał w rezydencji przy kościele Najświętszej Krwi Pana Jezusa w Poznaniu w latach 1765-1766 i ponownie od 1767.

${ }^{118}$ AKKr 174/614, s. 38; AKKr 175/547, s. 263; Zak. 66; Zak. 61, s. 131; ADP, C 54a, s. 29: członek konwentu w Gdańsku w 1758. Tonsurę i niższe święcenia otrzymał 11 czerwca 1758 w Kartuzach z rąk sufragana chełmińskiego Franciszka Fabiana Pląskowskiego.

${ }^{119}$ AKKr 175/547, s. 625; Zak. 66; Zak. 61, s. 302.

${ }^{120}$ AKKr 174/614, s. 20; AKKr 175/547, s. 289: podana data zgonu 24 maja 1817; Zak. 66.

${ }^{121}$ AKKr 175/547, s. 669; Zak. 66; Zak. 61, s. 324.

${ }^{122}$ AKKr 175/547, s. 129; Zak. 66; Zak. 61, s. 64; Zakonnicy, s. 334.

${ }^{123}$ AKKr 174/614, s. 14-15; AKKr 175/547, s. 73; Zak. 66; Zak. 61, s. 34: podana data zgonu 3 lutego 1789; Zakonnicy, s. 336.

${ }^{124}$ AKKr 174/614, s. 26-27; AKKr 175/547, s. 611; Zak. 66.

${ }^{125} \mathrm{AKKr} 174 / 614$, s. 22-23: podana data zgonu 13 marca 1792; AKKr 175/547, s. 123: podana data zgonu 2 marca 1792; Zak. 66: podana druga data zgonu 12 marca 1792; Zak. 61, s. 63: podane miejsce zgonu Włoszczawia.

${ }^{126}$ AKKr 175/547, s. 401; Zak. 66; Zak. 61, s. 193: podana data zgonu 12 lipca 1680.

${ }^{127}$ AKKr 174/614, s. 35: podana data zgonu 20 sierpnia 1760; Kart. 27, s. 407: brak daty urodzenia i złożenia profesji; AKKr 175/547, s. 471; Zak. 66; Zak. 61, s. 225: podana data zgonu 21 
Angelinus à S. Casimiro ARP ${ }^{128}$, ex prior Bidgostiensis et loci, nat. 1673, prof. 1690, obit. 18.10.1735 Kcynae.

Angelinus à S. Francisco RP ${ }^{129}$, concionator Polonorum, nat. 1737, prof. 1756, obit. 27.07.1773 Posnaniae.

Angelinus à S. Ignatio ARP, Woytkowski Ignatius ${ }^{130}$, ex prior Klodaviensis, sexennalis Lipiensis et septennalis Oboriensis, ex subprior Lipiensis, ex definitor provinciae, ex procurator Varsaviensis, magister novitiorum loci, actualis quadriennalis custos provinciae, nat. 25.09.1752, prof. 04.06.1775 Posnaniae, presb. 10.05.1778 Klodaviae, obit. 13.09.1821 Oboriis.

Angelinus à S. Michaele Ornowski ARP ${ }^{131}$, ex provincialis, ex prior Varsaviensis, ex definitor et ex secretarius provinciae, vir exemplaris ac devotus, qui ultimis annis suae vitae a comitetu fabricae conventus Klodaviensis constitutus praeses, sua sollicitudine multum fuit proficuus, nat. 1799, prof. 1824, presb. 1826, obit. 17.09.1855 Klodaviae.

Angelus à S. Alberto $\mathrm{RP}^{132}$, actualis subprior loci, nat. 1651, prof. 1671, obit. 14.07.1703 Gedani.

Angelus à S. Andrea Corsini $\mathrm{ARP}^{133}$, bis ex vicarius provincialis, ex prior Gedanensis ac loci, nat. 1636, prof. 1654, obit. 06.12.1716 Oboriis.

Angelus à S. Benedicto ARP, Chybinski Benedictus ${ }^{134}$, STL, ex definitor, ex prior Varsaviensis et Trutoviensis, nat. 20.03.1733, prof. 13.04.1753 Posnaniae, presb. 07.05.1758 Varsaviae, obit. 04.03.1814 Trutoviae.

Angelus à S. Bernardo RP, Berendt Antonius ${ }^{135}$, concionator Polonorum, nat. 31.07.1704, prof. 01.12.1720, obit. 03.03.1748 Markovicae.

Angelus à S. Gregorio $\mathrm{ARP}^{136}$, ex vicarius provinciae, ex prior Gedanensis et Oboriensis, nat. 1649, prof. 1675, obit. 23.02.1717 Oboriis. Gedani.

Angelus à S. Joanne Evangelista RP ${ }^{137}$, senior, nat. 1671, prof. 1690, obit. 17.04.1724

Angelus Zięba RP ${ }^{138}$, jubilatus, prior Leopoliensis, expertus in linguis orientalibus, omni mane „Godzinki” lingua syriaca cantavit, magnus cultor B.V. Mariae, nat. 19.04.1853, prof. 08.12.1877, presb. 20.02.1881, obit. 01.08.1934 Leopoli.

sierpnia 1760 Sztalmierz.

${ }^{128}$ AKKr 175/547, s. 587; Zak. 66; Zak. 61, s. 281: podana data zgonu 16 października 1735.

${ }^{129}$ AKKr 174/614, s. 38: podana data zgonu 25 czerwca 1773; AKKr 175/547, s. 419; Zak. 66; Kroniczka, s. 146, 161 i 199: kaznodzieja w klasztorze Bożego Ciała w Poznaniu w 1769.

${ }^{130}$ AKKr 174/614, s. 14-15; AKKr 175/547, s. 517; Zak. 66; ADWł, ABSWł 10, s. 65: święcenia subdiakonatu otrzymał 15 marca 1778, diakonatu 20 kwietnia 1778 i prezbiteratu 26 kwietnia 1778 we Włocławku z rąk sufragana włocławskiego Jana Dembowskiego.

${ }^{131}$ AKKr 175/547, s. 525; Zak. 66.

${ }^{132}$ AKKr 175/547, s. 393; Zak. 66; Zak. 61, s. 195.

${ }^{133}$ AKKr 175/547, s. 685; Zak. 66; Zak. 61, s. 332.

${ }^{134}$ AKKr 174/614, s. 6-7; Zak. 66; AKKr 175/547, s. 251: data zgonu 5 maja 1814.

${ }^{135}$ AKKr 174/614, s. 32; Kart. 27, s. 409; AKKr 175/547, s. 125; Zak. 66; Zak. 61, s. 68: podana data zgonu 9 marca 1748 .

${ }^{136}$ AKKr 175/547, s. 107; Zak. 66; Zak. 61, s. 54; Kroniczka, s. 189: przełożony rezydencji przy kościele Najświętszej Krwi Pana Jezusa w Poznaniu w 1708. Prawdopodobnie Anioł Stoiński prowincjał w latach 1713-1715.

${ }^{137}$ AKKr 175/547, s. 215; Zak. 66; Zak. 61, s. 107; Zakonnicy, s. 333.

${ }^{138} \mathrm{AKKr}$ 175/547, s. 429 i 493 (zapis został do druku skrócony): podana data zgonu 1 września 1934. 
Anselmus à S. Adalberto ARP, Gowinski Adalbertus ${ }^{139}$, STL, ex definitor, ex prior Oboriensis, Gedanensis, ac loci, nat. 26.03.1753, prof. 01.05.1771 Gedani, presb. 06.01.1777 Posnaniae, transivit ad provinciam Lithuaniae; docuit de licentia Generalis 8 annis laudabiliter iuventutem in Provincia Russiae Albae antiquae observantiae; adeptusque titulum doctoris, baccalaurei et magistri, quibus finitis reversus est ad provinciam nostram, obit. 07.04.1815 Trutoviae.

Anselmus à S. Maria ARP, Topolczik Paulus ${ }^{140}$, seniculus, concionator Polonorum, ex prior Drohobicensis, nat. 25.01.1691, prof. 01.04.1711, obit. 16.10.1760 Trutoviae.

Anselmus à S. Michaele Kazmierski ARP ${ }^{141}$, bis primitians, ex magister novitiorum, ex prior Plonscensis, Guloviensis, Varsaviensis et Trutoviensis, ex definitor, ex custos provinciae, ter ex praeses capituli, pluribus annis subprior Oboriensis ac Klodaviensis, morbo paralitico tactus Oboriis, in xenodochium Lipnense profectus ibique dies suos numeravit ultimos, ac in caemeterio parochiali sepultus est, nat. 1798, prof. 1814, presb. 1821, obit. 16.08.1872 Lipna.

Antonius à S. Adalberto Fr, Makowski Adalbertus ${ }^{142}$, nat. 18.04.1725, prof. 10.04.1746 Posnaniae, obit. 03.01.1780 Posnaniae.

Antonius à S. Andrea Corsini RP, Radoszewski Antonius ${ }^{143}$, emeritus, ex concionator Polonorum, ex prior Plonscensis et Lipiensis, subprior loci, nat. 11.09.1713, prof. 05.02.1732 Gedani, presb. 08.06.1738 Gedani, obit. 16.08.1775 Kcynae.

Antonius à S. Athanasio Fr, Burdanowicz Athanasius ${ }^{144}$, diaconus, studens theologiae, nat. 02.05.1763, prof. 27.06.1779 Posnaniae, obit. 11.05.1786 Posnaniae.

Antonius à S. Augustino Fr, Knorr Joannes ${ }^{145}$, pannifex, nat. 16.06.1692, prof. 29.08.1713, obit. 01.02.1745 Posnaniae.

Antonius à S. Barnaba Fr ${ }^{146}$, nat. 1643, prof. 1664, obit. 30.01.1676 Gedani.

Antonius à S. Bonaventura RP, Gajewski (Kajewski) Antonius ${ }^{147}$, nat. 08.04.1714, prof. 11.07.1742 Posnaniae, presb. 26.12.1747 Plonscii, obit. 06.04.1779 Klodaviae.

Antonius à S. Casimiro ARP, Jarecki Casimirus ${ }^{148}$, prior per tria triennia Klodaviensis et Kcynensis, definitor provinciae, nat. 02.03.1714, prof. 14.02.1731 Posnaniae, presb. 02.02.1740 Drohobiciis, obit. 11.08.1778 Posnaniae.

Antonius à S. Francisco Fr, Zakrzewski Franciscus ${ }^{149}$, prof. 01.08.1790 Gedani.

${ }^{139}$ AKKr 174/614, s. 12-13; AKKr 175/547, s. 195; Zak. 66; Zawadzki, s. 324: w 1804 był duszpasterzem w Lichnowach w części pomezańskiej diecezji chełmińskiej.

${ }^{140} \mathrm{AKKr} 174 / 614$, s. 35: podana data zgonu 16 listopada 1760; Kart. 27, s. 408; AKKr 175/547, s. 583; Zak. 66; Zak. 61, s. 312: podana data zgonu 16 listopada 1760.

${ }^{141}$ AKKr 175/547, s. 459.

${ }^{142}$ AKKr 174/614, s. 22-23 i 40; AKKr 175/547, s. 5: podany rok zgonu 1789; Zak. 66; Zak. 61, s. 3.

${ }^{143}$ AKKr 174/614, s. 2-3 i 39; Kart. 27, s. 411; AKKr 175/547, s. 459; Zak. 66.

${ }^{144}$ AKKr 174/614, s. 16-17: podana data zgonu 20 maja 1786; AKKr 175/547, s. 263; Zak. 66; Zak. 61, s. 131 i 136: zapis zgonu z datą 16 maja 1786 zamazany.

${ }^{145}$ AKKr 174/614, s. 31: podana data zgonu 7 lutego 1745; Kart. 27, s. 414; AKKr 175/547, s. 63; Zak. 66; Zak. 61, s. 6 i 32: podana druga data zgonu 6 stycznia 1745.

${ }^{146}$ AKKr 175/547, s. 59; Zak. 66; Zak. 61, s. 30.

${ }^{147}$ AKKr 174/614, s. 4-5 i 40; Kart. 27, s. 413; AKKr 175/547, s. 193; Zak. 66; Zak. 61, s. 96.

${ }^{148}$ AKKr 174/614, s. 2-3 i 40; Kart. 27, s. 411; AKKr 175/547, s. 389 i 449: na s. 389 podana data zgonu 12 lipca 1778; Zak. 66.

${ }^{149}$ AKKr 174/614, s. 28; TD, Metrykalia/Katolickie/Część 4, wpis nr 27537: zmarł 17 listopada 1837 w klasztorze w Kcyni w wieku 71 lat. 
Antonius à S. Francisco RP ${ }^{150}$, nat. 1677, prof. 1705, obit. 30.06.1731 Posnaniae.

Antonius à S. Joanne Evangelista RP ${ }^{151}$, nat. 1677, prof. 1696, obit. 01.12.1730 Posnaniae.

Antonius à S. Joanne $\mathrm{Fr}^{152}$, clericus, nat. 1643, prof. 1663, obit. 01.03.1676 Bidgostiae.

Antonius à S. Joanne $\mathrm{Fr}^{153}$, pictor praestantissimus, ecclesiam nostram Posnaniensem eleganti pictura adornavit, quae usqe ad praesens a spectantibus laudatur, Belga, nat. 1634, prof. 1655, obit. 29.11.1684 Posnaniae.

Antonius à S. Joanne RP, Elwart Joannes ${ }^{154}$, nat. 04.01.1760, prof. 06.07.1780 Gedani, presb. 10.07.1785 Gedani.

Antonius à S. Luca $\mathrm{Fr}^{155}$, nat. 1643, prof. 1665, obit. 16.01.1685 Posnaniae.

Antonius à S. Maria $\mathrm{Fr}^{156}$, clericus, nat. 1688, prof. 1706, obit. 21.07.1710 Posnaniae.

Antonius à S. Sebastiano ARP, Luba Sebastianus ${ }^{157}$, ex definitor, prior loci, nat. 20.01.1773, prof. 24.01.1789 Posnaniae, obit. 10.03.1826 Varsaviae.

Antonius ARP ${ }^{158}$, natione Polonus, ex procurator generalis, obit. 12.06.1825 Romae.

Antonius Zalewski $\mathrm{Fr}^{159}$, diaconus, emigrans in terram Sanctam, in via inter Acram et Caifam interfectus, ac sepultus in Monte Carmeli, obit. 30.11.1874.

Apollinaris à S. Jacobo RP, Berowski Jacobus ${ }^{160}$, nat. 18.03.1742, prof. 10.08.1758 Gedani, presb. 14.03.1765 Posnaniae, Apost. Calv.

Archangelus à Monte Carmelo RP, Jankie Josephus ${ }^{161}$, musicus, organarius tam figuralis quam choralis insignis et exorcista, nat. 02.04.1722, prof. 26.07.1745 Gedani, presb. 19.03.1752 Varsaviae, obit. 06.03.1777 Klodaviae.

Archangelus à S. Caecilia $\mathrm{Fr}^{162}$, clericus, organarius, nat. 1655, prof. 1673, obit. 10.07.1709 Posnaniae.

Archangelus à S. Martino RP ${ }^{163}$, organarius, nat. 1673, prof. 1694, obit. 15.05.1703 Posnaniae.

${ }^{150}$ AKKr 175/547, s. 365; Zak. 66; Zak. 61, s. 181.

${ }^{151}$ AKKr 175/547, s. 675; Zak. 66; Zak. 61, s. 327; Kroniczka, s. IX, 17 i 189: podprzeor klasztoru Bożego Ciała w Poznaniu w 1724. Rezydent w rezydencji przy kościele Najświętszej Krwi Pana Jezusa w Poznaniu w 1730 i piaty przełożony w 1730. Zmarł wkrótce po objęciu urzędu.

${ }^{152}$ AKKr 175/547, s. 121; Zak. 66; Zak. 61, s. 60.

${ }^{153}$ AKKr 175/547, s. 671; Zak. 66; Zak. 61, s. 325.

${ }^{154}$ AKKr 174/614, s. 16-17.

${ }^{155}$ AKKr 175/547, s. 31; Zak. 66; Zak. 61, s. 16.

${ }^{156}$ AKKr 175/547, s. 407; Zak. 66; Zak. 61, s. 202.

${ }^{157}$ AKKr 174/614, s. 18-19; AKKr 175/547, s. 139; Zak. 66.

${ }^{158}$ Zak. 66.

${ }^{159}$ AKKr 175/547, s. 673.

${ }^{160}$ AKKr 174/614, s. 6-7; ADWł, ABSWł 10, s. 12; Kroniczka, s. 42 i 192: członek konwentu w Bydgoszczy w 1761. Tonsurę i niższe święcenia otrzymał 28 października $1761 \mathrm{w}$ kościele klarysek w Bydgoszczy z rąk sufragana włocławskiego Jana Dembowskiego. Student teologii w klasztorze Bożego Ciała w Poznaniu w 1765.

${ }^{161}$ AKKr 174/614, s. 4-5 i 39; AKKr 175/547, s. 131; Zak. 66; Zak. 61, s. 65.

${ }^{162}$ AKKr 175/547, s. 385; Zak. 66; Zak. 61, s. 191.

${ }^{163}$ AKKr 175/547, s. 271; Zak. 66; Zak. 61, s. 135. 
Arnoldus à S. Antonio RP, Bogulski Antonius ${ }^{164}$, nat. 12.06.1763, prof. 27.06.1779 Posnaniae, presb. nescitur ubi.

Arnoldus à S. Antonio RP, Gorski (Gurski) Antonius ${ }^{165}$, concionator, emeritus, actualis syndicus provinciae, nat. 13.06.1709, prof. 20.01.1726 Gedani, presb. 06.01.1733 Posnaniae, obit. 08.01.1774 Posnaniae, in capella Sanguinis Christi.

Arnoldus à SS. Trinitate RP ${ }^{166}$, STL, jubilatus, nat. 1677, prof. 1693, obit. 17.09.1725 Oboriis.

Arsenius à S. Petro RP, Stawski Petrus ${ }^{167}$, subprior loci, nat. 03.07.1748, prof. 01.03.1767 Posnaniae, presb. 1776, obit. 04.05.1811 Klodaviae.

Athanasius à S. Josepho RP, Szatwicki Josephus ${ }^{168}$, nat. 16.03.1744, prof. 12.07.1765 Posnaniae, presb. 12.08.1770 Varsaviae, obit. 15.02.1781 Drohobiciis.

Athanasius à S. Martino RP, Balman Martinus ${ }^{169}$, nat. 16.11 .1766 , prof. $1781 \mathrm{Ge}-$ dani, non est dies et mensis, presb. Cracoviae.

Athanasius à S. Paulo RP, Andrykowicz Josephus ${ }^{170}$, nat. 08.03.1706, prof. 13.07.1726, obit. 22.12.1757 in Hungaria villa Wereckie.

Athanasius à S. Stanislao RP ${ }^{171}$, nat. 1678, prof. 1696, obit. 11.11.1708 Posnaniae.

Augustinus à S. Antonio ARP, Piotrowicz Antonius ${ }^{172}$, STL, ex provincialis, ex definitor provinciae, ex magister novitiorum, ex prior Bidgostiensis, Gedanensis, ac aliquoties Varsaviensis, nat. 16.11.1722, prof. 21.04.1739 Gedani, presb. 10.04.1746 Gedani, obit. 20.03.1799 Varsaviae.

Augustinus à S. Joanne Baptista RP ${ }^{173}$, nat. 1646, prof. 1665, obit. 19.11.1695 Gedani.

${ }^{164}$ AKKr 174/614, s. 16-17.

${ }^{165}$ AKKr 174/614, s. 2-3 i 39; Kart. 27, s. 410; AKKr 175/547, s. 15; Zak. 66; Zak. 61, s. 8; AAG, ACap B 80, s. 4v: członek konwentu w Poznaniu w 1732. Święcenia prezbiteratu otrzymał 20 grudnia 1732 w katedrze w Gnieźnie z rąk sufragana gnieźnieńskiego Józefa Trzcińskiego; Kroniczka, s. VII, IX, 27, 53, 63, 66, 71, 74, 76, 82, 90, 94, 98, 104-106, 112-113, 115, 119, 130-131, 142, 157-159, 166, 180 i 189: syndyk prowincji i prokurator konwentu Bożego Ciała w Poznaniu w 1751. Przebywał w klasztorach w Bydgoszczy i Gdańsku. Prezydent w rezydencji przy kościele Najświętszej Krwi Pana Jezusa w Poznaniu w 1769. Przebywał w rezydencji wiele lat (od 1751). Autor kroniczki i diariusza rezydencji.

${ }^{166}$ AKKr 175/547, s. 525; Zak. 66; Zak. 61, s. 252.

${ }^{167}$ AKKr 174/614, s. 10-11; AKKr 175/547, s. 249; Zak. 66; Bibliografia Polska. XIX Stólecia, przez K. Estreichera, T. IV (R-U), Kraków 1878, s. 378: opublikował: Mowa w dzień nowego roku w kościele kłodawskim miana $r .1807$ przez Józefa Kossowskiego znanego w literaturze polskiej do druku podana.

${ }^{168}$ AKKr 174/614, s. 8-9 i 41; AKKr 175/547, s. 61: podana data zgonu 31 stycznia 1781; Zak. 61, s. 45 i 46: podana druga data zgonu 14 lutego 1781; ADP, C 54a, s. 70: członek konwentu w Bydgoszczy w 1767. Święcenia subdiakonatu otrzymał 19 września 1767 w Chełmży z rąk sufragana chełmińskiego Franciszka Fabiana Pląskowskiego.

${ }^{169}$ AKKr 174/614, s. 16-17.

${ }^{170}$ AKKr 174/614, s. 34; Kart. 27, s. 410; AKKr 175/547, s. 717; Zak. 66.

${ }^{171}$ AKKr 175/547, s. 635; Zak. 66; Zak. 61, s. 307.

${ }^{172}$ AKKr 174/614, s. 2-3; Kart. 27, s. 412; AKKr 175/547, s. 159; Zak. 66; Zak. 61, s. 79; Kroniczka, s. 179, 180, 185 i 202: prowincjał w 1769.

${ }^{173}$ AKKr 175/547, s. 651; Zak. 66; Zak. 61, s. 316: podana data zgonu 20 listopada 1695. 
Augustinus à S. Monica RP ${ }^{174}$, subprior loci, nat. 1667, prof. 1688, obit. 24.02.1706 Bidgostiae.

Augustinus à S. Sabina $\mathrm{ARP}^{175}$, ex prior loci, nat. 1683, prof. 1707, obit. 09.11.1719 Drohobiciis.

Augustinus à S. Simone Muszczyński (Moszczynski) RP ${ }^{176}$, ex lector theologiae moralis et philosophiae, in lingua germanica et gallica peritus, vir doctus, devotus atque laboriosus in officiis suis, nat. 1775, prof. 1803, presb. 1802, obit. 26.09.1828 Oboriis.

Augustinus à S. Thoma Jajko RP ${ }^{177}$, nat. 1800, presb. 1834, obit. 14.03.1890 Oboriis.

Augustinus à S. Tiburtio ARP, Czarnecki Joannes ${ }^{178}$, ex prior Kcynensis, Markovicensis et Plonscensis, actualis prior loci, nat. 30.04.1699, prof. 12.08.1720, obit. 26.08.1751 Drohobiciis.

Aurelius à S. Josepho RP, Czayczynski Josephus ${ }^{179}$, nat. 12.03.1770, prof. 17.11.1787 Posnaniae.

Avertanus à S. Antonio Fr ${ }^{180}$, nat. 1757, prof. 1778, obit. 17.09.1797 Lipiae.

Avertanus à S. Christophoro ARP ${ }^{181}$, ex prior Bidgostiensis, nat. 1673, prof. 1690, obit. 19.05.1713 Drohobiciis.

Avertanus à S. Joanne Fr, Nierzalewski Joannes ${ }^{182}$, nat. 17.10.1747, prof. 29.06.1773 Gedani, obit. 28.08.1797 Lipiae.

Avertanus à S. Ludovico RP, Schmidt Ludovicus ${ }^{183}$, nat. 28.03.1759, prof. 16.07.1781 Posnaniae, presb. 22.07.1783 Gedani, obit. 02.09.1792 Plonscii.

Avertanus à S. Romaeo $\mathrm{Fr}^{184}$, nat. 1668, prof. 1688, obit. 16.11.1707 Bidgostiae.

Avertanus à S. Sabina Jędritzki RP ${ }^{185}$, concionator Germanorum, nat. 1698, prof. 1720, obit. 08.05.1728 Gedani.

Avertanus à S. Scholastica Fr, Kierfeld Thomas ${ }^{186}$, sutor, hortulanus, nat. 02.01.1702, prof. 13.09.1732, obit. 22.04.1770 Kcynae.

Avertanus à S. Stanislao, Kostka Borowiecki ARP ${ }^{187}$, ex definitor provinciae, nat. 1801, prof. 1826, presb. 1830, obit. 24.09.1859 Oboriis.

${ }^{174}$ AKKr 175/547, s. 109; Zak. 66; Zak. 61, s. 55; ADP, A 41, s. 5: święcenia diakonatu otrzymał 20 maja 1690 w katedrze w Chełmży z rąk sufragana chełmińskiego Tomasza Skotnickiego.

${ }^{175}$ AKKr 175/547, s. 631; Zak. 66; Zak. 61, s. 305; ADP, A 41, s. 27: członek konwentu w Gdańsku w 1707. Tonsurę i niższe święcenia otrzymał 24 września 1707 w katedrze w Chełmży z rąk sufragana chełmińskiego Seweryna Szczuki.

${ }^{176} \mathrm{AKKr}$ 175/547, s. 543; Zak. 66: podana data zgonu 29 czerwca 1828.

${ }^{177}$ AKKr 175/547, s. 147.

${ }^{178}$ AKKr 174/614, s. 32; Kart. 27, s. 409; AKKr 175/547, s. 481; Zak. 66; Zak. 61, s. 230.

${ }^{179}$ AKKr 174/614, s. 18-19.

${ }^{180}$ Zak. 66.

${ }^{181}$ AKKr 175/547, s. 279; Zak. 66; Zak. 61. s. 139.

${ }^{182}$ AKKr 174/614, s. 26-27; Zak. 61, s. 232.

${ }^{183}$ AKKr 174/614, s. 16-17; AKKr 175/547, s. 431: podana data zgonu 2 sierpnia 1792; Zak. 66; Zak. 61, s. 214: podana data zgonu 2 sierpnia 1792.

${ }^{184}$ AKKr 175/547, s. 645; Zak. 66; Zak. 61, s. 312 i 156: podana data zgonu 5 czerwca 1708.

${ }^{185}$ AKKr 175/547, s. 257; Zak. 66; Zak. 61, s. 129: podana data zgonu 9 maja 1728; Zakonnicy, s. 333: podana data zgonu 12 kwietnia 1728.

${ }^{186}$ AKKr 174/614, s. 37; Kart. 27, s. 415; AKKr 175/547, s. 225; Zak. 66; Zak. 61, s. 112.

${ }^{187}$ AKKr 175/547, s. 539; Zak. 66. 
Avertanus à S. Venantio $\mathrm{Fr}^{188}$, sartor, sutor, nat. 1698, prof. 1721, obit. 17.04.1741 Varsaviae.

Avertanus à SS. Petro \& Paulo ARP, Jankowski Adamus ${ }^{189}$, ex prior Lipiensis, Plonscensis, Markovicensis, Bidgostiensis et Trutoviensis, ex praesidens residentiae Sanguinis Christi, pluries subprior, saepius activus procurator, nat. 18.12.1705, prof. 26.06.1729 Gedani, presb. 25.03.1731 Gedani, obit. 31.05.1780 Posnaniae.

Avertanus ab Ascensione Domini Fr, Majewski Adalbertus ${ }^{190}$, nat. 14.04.1680, prof. 10.06.1714, obit. 27.04.1747 Varsaviae.

Balthassar à S. Andrea $\mathrm{Fr}^{191}$, oeconomus, nat. 1735, prof. 1755, obit. 08.03.1770 Oboriis.

Balthassar à S. Georgio RP, Gertler Georgius ${ }^{192}$, nat. 01.08.1719, prof. 10.03.1742, obit. 31.10.1768 Drohobiciis.

Balthassar à S. Josepho ARP, Nowi Josephus ${ }^{193}$, STL, ex prior Varsaviensis et Posnaniensis, ex praesidens, ex secretarius provinciae, provincialis reelectus, vir doctus, prudens et verus amator clericorum, nat. 01.04.1769, prof. 1788 Gedani, presb. 1792, obit. 27.05.1817 Oboriis, obiit immediate post capitulum provinciale.

Barnabas à S. Gasparo RP, Kliszewski Gaspar ${ }^{194}$, nat. 11.01.1741, prof. 16.06.1760 Posnaniae, presb. 13.04.1764 Posnaniae. Dispensatus pro beneficio saeculari. Obiit.

Barnabas à S. Hyacintho RP, Szanowski Hyacinthus ${ }^{195}$, nat. 31.08.1762, prof. 13.12.1778 Gedani, presb. 29.09.1785 Posnaniae.

Bartholomaeus à S. Adalberto Fr, Bładoszewski Adalbertus ${ }^{196}$, nat. 21.04.1752, prof. 11.12.1788 Gedani.

Bartholomaeus à S. Adriano ARP, Drzewicki Michael ${ }^{197}$, ex concionator Polonorum, ex praesidens capellae Sanguinis Christi, magister novitiorum ac subprior, seniculus, nat. 04.02.1674, prof. 25.09.1698, obit. 12.03.1732 Klodaviae.

Bartholomaeus à S. Martino RP, Jaczynski Martinus ${ }^{198}$, nat. 09.11.1717, prof. 28.08.1747 Posnaniae, presb. 16.02.1749 Markovicae, obit. 11.01.1781 Oboriis.

Basilius à Purificatione B.M.V. RP, Marlikiewicz Josephus ${ }^{199}$, nat. 23.03.1690, prof. 02.02.1709, obit. 16.12.1750 Plonscii.

${ }^{188} \mathrm{AKKr} 175 / 547$, s. 215; Zak. 66.

${ }^{189} \mathrm{AKKr} 174 / 614$, s. $2-3$ i 41: na s. $2-3$ podana data zgonu 1 czerwca 1780 ; Kart. 27, s. 410; AKKr 175/547, s. 301: podana data zgonu 30 maja 1780; Zak. 66; Zak. 61, s. 151.

${ }^{190}$ AKKr 174/614, s. 31; Kart. 27, s. 414.

${ }^{191}$ AKKr 174/614, s. 37; AKKr 175/547, s. 137; Zak. 66; Zak. 61, s. 65.

${ }^{192}$ AKKr 174/614, s. 37; Kart. 27, s. 413; AKKr 175/547, s. 613; Zak. 66; Zak. 61, s. 295: podana data zgonu 30 października 1768.

${ }^{193}$ AKKr 174/614, s. 18-19; AKKr 175/547, s. 295; Zak. 66.

${ }^{194}$ AKKr 174/614, s. 8-9.

${ }^{195}$ AKKr 174/614, s. 16-17.

${ }^{196}$ AKKr 174/614, s. 28.

${ }^{197}$ AKKr 174/614, s. 31: podany rok zgonu 1748; Kart. 27, s. 407; AKKr 175/547, s. 143; Zak. 66; Zak. 61, s. 71: podana data zgonu 12 marca 1748; Kroniczka, s. 17, 18 i 189: kaznodzieja i mistrz nowicjatu w klasztorze Bożego Ciała w Poznaniu w 1724. Szósty przełożony rezydencji przy kościele Najświętszej Krwi Pana Jezusa w Poznaniu w latach około 1730-1733. Potem ponownie w klasztorze Bożego Ciała jako custos sacrarum.

${ }^{198}$ AKKr 174/614, s. 4-5 i 41; AKKr 175/547, s. 21; Zak. 66; Zak. 61, s. 11.

${ }^{199}$ AKKr 174/614, s. 32; Kart. 27, s. 408; AKKr 175/547, s. 705; Zak. 66; Zak. 61, s. 341. 
Basilius à S. Andrea RP ${ }^{200}$, nat. 1648, prof. 1664, obit. 30.01.1699 Bidgostiae.

Basilius à S. Christophoro Wesołowski $\mathrm{Fr}^{201}$, quaestiarius et sartor, nat. 1763, prof. 1783, obit. 07.03.1823 Oboriis.

Basilius à S. Francisco ARP202, secretarius provinciae, nat. 1731, prof. 1748, obit. 29.02.1764 Bidgostiae.

Basilius à S. Hyacintho ARP ${ }^{203}$, ex prior Gedanensis, nat. 1595, prof. 1614, obit. 02.01.1682 Bidgostiae.

Basilius à S. Joanne ARP, Lyszniewski Joannes ${ }^{204}$, ex prior Markovicensis et Klodaviensis, ex definitor, nat. 25.12.1750, prof. 16.11.1769 Gedani, presb. 03.04.1774 Varsaviae, obit. 20.01.1819 Klodaviae.

Basilius à S. Joanne $\mathrm{Fr}^{205}$, nat. 1762, prof. 1786, obit. 11.11.1792 Plonscii.

Basilius à S. Paulo Fr, Lissowski Paulus ${ }^{206}$, prof. 24.06.1786 Gedani.

Basilius à S. Stanislao Ciupak RP ${ }^{207}$, ex concionator Varsaviensis et Trutoviensis, subprior Trutoviensis et Oboriensis, subprior loci, nat. 1800, prof. 1831, presb. 1835, obit. 11.04.1851 Lipiae.

Basilius à SS. Trinitate $\mathrm{RP}^{208}$, STL, jubilatus, in singulari memoriae facilitate intellectusque sagacitate prae aliis coaetaneis excelluit, theologus et concionator insignis, nat. 1670, prof. 1690, obit.14.08.1707 Gedani.

Benedictus à S. Francisco Fr, Bronisz Franciscus ${ }^{209}$, terminarius, pluribus annis dispensator bene commendatus, nat. 02.04.1725, prof. 16.10.1755 Posnaniae, obit. 26.12.1794 Klodaviae.

Benedictus à S. Gertrude $\mathrm{Fr}^{210}$, clericus, nat. 1634, prof. 1655, obit. 05.02.1677 Posnaniae.

Benedictus à S. Ignatio ARP, Krügier Joannes ${ }^{211}$, ex secretarius provinciae, ex prior Posnaniensis et Kcynensis, ex definitor, prior loci, nat. 16.06.1720, prof. 01.07.1740 Posnaniae, presb. 25.08.1745 Posnaniae, obit. 20.04.1782 Kcynae.

${ }^{200}$ AKKr 175/547, s. 59; Zak. 66; Zak. 61, s. 30.

${ }^{201}$ Zak. 66; AKKr 175/547, s. 143 i 147: podane daty zgonu 12 i 14 marca 1823.

${ }^{202}$ AKKr 174/614, s. 36: podana data zgonu 26 lutego 1764; AKKr 175/547, s. 119; Zak. 66; Zak. 61, s. 57: podana data zgonu 26 lutego $1764 \mathrm{w}$ Ślesinie, pochowany w Bydgoszczy.

${ }^{203}$ AKKr 175/547, s. 3; Zak. 66; Zak. 61, s. 2.

${ }^{204}$ AKKr 174/614, s. 12-13; Zak. 66; AKKr 175/547, s. 39 i 67: po raz drugi zgon 3 lutego 1819; AAG, ACon E 19, s. 28-30v: w 1779 był kapelanem w Mirosławicach na terenie parafii Kościeszki.

${ }^{205}$ Zak. 66; Zak. 61, s. 307.

${ }^{206}$ AKKr 174/614, s. 28.

${ }^{207}$ AKKr 175/547, s. 203; Zak. 66.

${ }^{208}$ AKKr 175/547, s. 455 i 457: na s. 455 podany błędnie rok zgonu 1797, na s. 457 drugi zapis zgonu z datą 15 sierpnia 1707; Zak. 66; Herbarz Polski Kaspra Niesieckiego SJ powiększony dodatkami z późniejszych autorów, rękopismów, dowodów urzędowych i wydany przez Jana Nep. Bobrowicza, T. 6, Lipsk 1841, s. 430: prawdopodobnie syn Kaspra Młodziejowskiego i jego drugiej żony Witowskiej. Zmarł jako kaznodzieja w Gdańsku.

${ }^{209}$ AKKr 174/614, s. 22-23; AKKr 175/547, s. 665 i 725: podana druga data zgonu 26 listopada 1794; Zak. 66.

${ }^{210}$ AKKr 175/547, s. 71; Zak. 66; Zak. 61, s. 36.

${ }^{211}$ AKKr 174/614, s. 4-5 i 41: na s. 4-5 podana data zgonu 21 kwietnia 1782; Kart. 27, s. 413; AKKr 175/547, s. 185; Zak. 66: podana data zgonu 21 kwietnia 1782; Kroniczka, s. 69, 77, 82, 90, 
Benedictus à S. Josepho RP Cielecki Michael ${ }^{212}$, subdiaconus, nat. 1687, prof. 1703, obit. 11.10.1709 Gedani.

Benedictus à S. Josepho RP, Swierbel Josephus ${ }^{213}$, ex concionator Polonorum, nat. 27.03.1749, prof. 10.12.1768 Posnaniae, presb. 20.04.1772 Gedani, obit. 28.04.1795 Markovicae.

Benedictus à S. Patritio $\mathrm{Fr}^{214}$, terminarius, ferrifaber, nat. 1693, prof. 1716, obit. 24.12.1761 Lipiae.

Benedictus ab Annuntiatione B.M.V. ARP ${ }^{215}$, ex prior Klodaviensis, nat. 1691, prof. 1720, obit. 02.04.1740 Kcynae.

Benedictus Fabijanowski Fr ${ }^{216}$, diaconus, nat. 1843, obit. 09.10.1867 Imielna.

Benignus à S. Simone ARP, Wołynkiewicz Simon ${ }^{217}$, STL, ex secretarius provinciae, ex prior Posnanensis et secundo triennio actualis prior loci, nat. 30.11.1750, prof. 04.02.1767 Posnaniae, presb. 22.12.1770 Posnaniae, obit. 15.10.1797 Oboriis.

Benno à S. Michaele RP, Kuchn Michael ${ }^{218}$, pluribus annis officium concionatoris Germanorum Gedani laudabiliter exercuit, nat. 01.09.1732, prof. 18.10.1752 Gedani, presb. 27.01.1757 Varsaviae, obit. 10.08.1774 Trutoviae.

Bernardinus (Bernardus) ab Assumptione B.M.V. ARP, Krassowski Stanislaus ${ }^{219}$, ex prior Posnanensis, Oboriensis et Trutoviensis, nat. 18.11.1697, prof. 22.08.1723, obit. 12.01.1745 Klodaviae.

Bernardinus à S. Georgio Fr, Hainnicht Georgius ${ }^{220}$, terminarius pro residentia, nat. 14.03.1751, prof. 04.06.1780 Posnaniae, obit. 08.09.1786 Posnaniae, in residentia Sanguinis Christi.

Bernardinus à S. Simone RP, Kreibich Joannes ${ }^{221}$, musicus, nat. 13.11.1719, prof. 21.05.1739 Gedani, presb. 24.06.1743 Posnaniae, obit. 06.05.1784 Markovicae.

Bernardus à Puero Jezu RP222, nat. 1642, prof. 1660, obit. 23.03.1682 Bidgostiae.

93, 96, 104, 106, 109, 115, 122, 123, 126, 127, 131, 132, 138, 139, 141, 152, 157, 158, 163, 191 i 200: przeor w klasztorze Bożego Ciała w Poznaniu w latach 1766-1769.

${ }^{212}$ AKKr 175/547, s. 573; Zak. 66; Zak. 61, s. 276; ADP, A 41, s. 27; TD, Grodzkie i ziemskiePoznań-Inskrypcje-XVII/XVIII wieku, wpis nr 6209: syn Aleksandra i Magdaleny Trąmpczyńskiej. W 1703 zapisuje swój majątek po rodzicach konwentowi Bożego Ciała w Poznaniu. Członek konwentu w Gdańsku w 1707. Tonsurę i niższe święcenia otrzymał 24 września 1707 w katedrze w Chełmży z rąk sufragana chełmińskiego Seweryna Szczuki.

${ }^{213}$ AKKr 174/614, s. 10-11; AKKr 175/547, s. 237; Zak. 66; Zak. 61, s. 118.

${ }^{214}$ AKKr 174/614, s. 35; Kart. 27, s. 414; poza imionami zakonnymi brak danych; AKKr 175/547, s. 721; Zak. 66.

${ }^{215}$ AKKr 175/547, s. 185; Zak. 66; Zak. 61, s. 92 i 126: podana druga data zgonu 6 maja 1740.

${ }^{216}$ AKKr 175/547, s. 569.

${ }^{217}$ AKKr 174/614, s. 10-11; AKKr 175/547, s. 599; Zak. 66; Zak. 61, s. 288: podana data zgonu 23 października 1797.

${ }^{218}$ AKKr 174/614, s. 6-7 i 39: podana data zgonu 7 sierpnia 1774; AKKr 175/547 s. 227; Zak. 66; Zak. 61, s. 222: podane imiona zakonne Bruno à S. Michaele.

${ }^{219}$ AKKr 174/614, s. 31: podana data zgonu 12 stycznia 1747 w Kowalewie; Kart. 27, s. 410; AKKr 175/547, s. 23; Zak. 66; Zak. 61, s. 14: podana data zgonu 14 stycznia 1747.

${ }^{220} \mathrm{AKKr} 174 / 614$, s. 26-27: podana data zgonu 4 września 1786; AKKr 175/547, s. 525: podana data zgonu 17 września 1786; Zak. 66; Zak. 61, s. 243.

${ }^{221}$ AKKr 174/614, s. 2-3; Kart. 27, s. 412: podana data urodzenia 10 lutego 1719; AKKr 175/547, s. 253; Zak. 66; Zak. 61, s. 126.

${ }^{222}$ AKKr 175/547, s. 165; Zak. 66; Zak. 61, s. 82. 
Bernardus à S. Bartholomaeo ARP ${ }^{223}$, ex prior Bidgostiensis, nat. 1678, prof. 1695, obit. 22.02.1725 Kcynae.

Bernardus à S. Benedicto RP ${ }^{224}$, nat. 1649, prof. 1670, obit. 07.06.1692 Bidgostiae.

Bernardus à S. Joanne Evangelista RP, Piątkowski Adamus ${ }^{225}$, nat. 24.12.1723, prof. 12.01.1748 Posnaniae, presb. 09.09.1753 Varsaviae, obit. 30.07.1776 in Villa Drwale, sepultus Lipiae.

Bernardus à S. Josepho RP, Białk Josephus ${ }^{226}$, nat. 11.05.1761, prof. 24.08.1779 Gedani, presb. 10.06.1784 Varsaviae, obit. 23.04.1789 Lipiae.

Bertholdus à S. Adalberto ARP, Hosztowski Adalbertus ${ }^{227}$, STL, ex provincialis, ex prior Markovicensis et Plonscensis, praeses capituli, actualis definitor provinciae, nat. 19.04.1742, prof. 07.06.1759 Gedani, presb. 04.06.1765 Varsaviae, obit. 22.08.1797 sub manu medici Varsaviae.

Bertholdus à S. Antonio $\rightarrow$ Bertholdus à S. Francisco Xaverio

Bertholdus à S. Francisco Xaverio Kelch $\mathrm{Fr}^{228}$, clericus, diaconus, nat. 1790, prof. 1825, obit. 27.04.1832 Varsaviae.

Bertholdus à S. Josepho $\mathrm{Fr}^{229}$, nat. 1666, prof. 1687, obit. 14.12.1739 Plonscii.

Bertholdus à S. Michaele RP ${ }^{230}$, magister novitiorum, Longaevus, nat. 1667, prof. 1687, obit. 04.04.1726 Drohobiciis.

Bertholdus à S. Paulo RP ${ }^{231}$, nat. 1599, prof. 1620, obit. 01.06.1685 Oboriis.

Bertholdus à S. Petro ARP, Skoczynski Petrus ${ }^{232}$, STL, magister novitiorum, jubilatus, ex provincialis, bis primitians, septies definitor, ex prior quattuor triennis Bidgostiensis et uno Gedanensis. Vir doctus, contemplativus et activus, strictioris observantiae nostrae cultor eximius, peritissimus in cantu chorali, cuius plenissimam Instructionem ac Processionale correctum praelo mandavit, Hymnarium conscripsit. Eius activitate et industria, vetusta conventus Bidgostiensis structura, in recentiorem et commoditati fratrum aptiorem transformata est; nat. 15.07.1700, prof. 22.09.1716 Gedani, presb. 15.08.1723 Varsaviae, obit. 24.07.1776 Gedani.

Bertholdus Mamelski RP ${ }^{233}$, concionator et subprior loci, nat. 1790, prof. 1809, presb. 1814, obit. 09.10.1821 Markovicae.

${ }^{223}$ AKKr 175/547, s. 105; Zak. 66; Zak. 61, s. 53; ADP, A 41, s. 18, 18v i 22: błędnie podane 22 marca 1698. Suche dni były od 20 lutego tego roku. Członek konwentu w Bydgoszczy w latach 1697-1698. Święcenia subdiakonatu otrzymał 21 grudnia 1697, diakonatu 22 lutego 1698 i prezbiteratu 15 marca 1698 w katedrze w Chełmży z rąk sufragana chełmińskiego Tomasza Skotnickiego.

${ }^{224}$ AKKr 175/547, s. 317; Zak. 66; Zak. 61, s. 158.

${ }^{225}$ AKKr 174/614, s. $4-5$ i 39: na s. 39 podane miejsce zgonu Drwalewo; AKKr 175/547 s. 425 : podane miejsce zgonu Drwalewo; Zak. 66: podane miejsce zgonu Warszawa; Zak. 61, s. 212: podana data zgonu 31 lipca 1776.

${ }^{226}$ AKKr 174/614, s. 16-17; AKKr 175/547 s. 227; Zak. 66.

${ }^{227}$ AKKr 174/614, s. 8-9; AKKr 175/547, s. 471; Zak. 66; Zak. 61, s. 226.

${ }^{228}$ AKKr 175/547 s. 235; Zak. 66: podana data zgonu 23 września 1832 Wąsosia oraz imiona zakonne Bertholdus à S. Antonio.

${ }^{229}$ AKKr 175/547 s. 701; Zak. 66; Zak. 61, s. 339.

${ }^{230}$ AKKr 175/547 s. 189; Zak. 66; Zak. 61, s. 94.

${ }^{231}$ AKKr 175/547 s. 305; Zak. 66; Zak. 61, s. 152.

${ }^{232}$ AKKr 174/614, s. 2-3 i 39; Kart. 27, s. 408: podana data urodzenia 18 lipca 1700; AKKr 175/547, s. 413; Zak. 66; Zak. 61, s. 205; Zakonnicy, s. 336: podany tylko rok zgonu.

${ }^{233}$ AKKr 175/547, s. 569; Zak. 66 
Boguslaus à S. Josepho RP, Wolski Mathias ${ }^{234}$, per multos annos oeconomus in Stara Łąka et in Sztalmierz, nat. 16.01.1710, prof. 29.07.1749 Gedani, presb. 08.12.1751 Kcynae, obit. 31.07.1790 Oboriis.

Bonaventura à S. Andrea Fr. Granau Andreas ${ }^{235}$, sartor, nat. 26.11.1753, prof. 13.07.1785 Posnaniae, obit. 12.04.1794 Lipiae.

Bonaventura à S. Antonio Wydryszewski RP ${ }^{236}$, studens theologiae moralis, nat. 1756, prof. 1775, obit. 12.11.1779 Plonscii.

Bonaventura à S. Bartolomaeo Pomorski ARP ${ }^{237}$, ex praeses capituli, bis ex definitor provinciae, ex magister novitiorum, ex prior Lipiensis et Guloviensis, actualis prior loci, nec non actualis definitor provinciae, eius cura, activitate et industria conventus Guloviensis totaliter de muro extructa est, nat. 1796, prof. 1816, presb. 1822, obit. 30.10 .1847 Vąsosiae.

Bonaventura à S. Leonardo RP ${ }^{238}$, lector philosophiae, nat. 1709, prof. 1725, obit. 06.03.1741 Gedani.

Bonaventura à S. Nicolao RP ${ }^{239}$, nat. 1703, prof. 1726, obit. 21.04.1742 Posnaniae.

Bonaventura à S. Simone RP, Piotrowski Simon ${ }^{240}$, actualis concionator Polonorum, nat. 28.10.1753, prof. 03.08.1775 Gedani, presb. 21.03.1777 Klodaviae, obit. 22.01.1787 Klodaviae.

Bonaventura à S. Valentino RP241, concionator Polonorum, nat. 1718, prof. 1744, obit. 03.10.1756 Kcynae.

Bonifacius à S. Anna $\mathrm{Fr}^{242}$, nat. 1667, prof. 1688, obit. 21.06.1709 Posnaniae.

Bonifacius à S. Josepho $\mathrm{RP}^{243}$, procurator, nat. 1725, prof. 1751, presb. 1758, obit. 23.01.1773 Drohobiciis.

${ }^{234}$ AKKr 174/614, s. 4-5: podana data zgonu 8 lipca 1790; AKKr 175/547, s. 427; Zak. 66; Zak. 61, s. 212; ADP, G 72, k.316v, 318 i 326v; J. Fankidejski, Utracone kościoly i kaplice w dzisiejszej dyecezyi chetmińskiej, Pelplin 1880, s. 185: W 1782 był kapelanem domowym w Reksynie [Raszynie] u miecznika pruskiego Waleriana Piwnickiego.

${ }^{235} \mathrm{AKKr} 174 / 614$, s. 26-27; AKKr 175/547, s. 211: podana data zgonu 15 kwietnia 1794; Zak. 66.

${ }^{236}$ AKKr 174/614, s. 40; AKKr 175/547, s. 637; Zak. 66; Zak. 61, s. 308; ADWł, ABSWł 10, s. 65: święcenia subdiakonatu otrzymał 15 marca 1778, diakonatu 20 kwietnia 1778 i prezbiteratu 26 kwietnia 1778 we Włocławku z rąk sufragana włocławskiego Jana Dembowskiego.

${ }^{237}$ AKKr 175/547, s. 611; Zak. 66: podana data zgonu 31 października 1847.

${ }^{238}$ AKKr 175/547, s. 131; Zak. 66; Zak. 61, s. 65; AAG, ACap B 80, s. 4v; Zakonnicy, s. 334: członek konwentu w Poznaniu w 1732. Święcenia prezbiteratu otrzymał 20 grudnia $1732 \mathrm{w}$ katedrze w Gnieźnie z rąk sufragana gnieźnieńskiego Józefa Trzcińskiego.

${ }^{239}$ AKKr 174/614, s. 31; AKKr 175/547, s. 223; Zak. 66; Zak. 61, s. 111 i 112: zapis przekreślony, a na kolejnej stronie podana data zgonu 22 kwietnia 1742.

${ }^{240}$ AKKr 174/614, s. 14-15; Zak. 66; AKKr 175/547, s. 41: podana data zgonu 21 stycznia 1787; Zak. 61, s. 22.

${ }^{241}$ AKKr 174/614, s. 34: podana data zgonu 21 października 1756; AKKr 175/547, s. 557; Zak. 66; Zak. 61, s. 266 i 286: podane daty zgonu 1 października 1756 i 21 października 1756 Jastrowie.

${ }^{242}$ AKKr 175/547, s. 347; Zak. 66; Zak. 61, s. 172.

${ }^{243}$ AKKr 174/614, s. 38; AKKr 175/547, s. 45; Zak. 66: data zgonu 24 stycznia 1773; Zak. 61, s. 23; AAG, ACon G II 4, s. 75 (t), 74 (d), 76v (s): tonsurę otrzymał 24 maja 1755, świecenia subdiakonatu 20 grudnia 1755 i diakonatu 26 grudnia 1755 w katedrze w Gnieźnie z rąk sufragana gnieźnieńskiego Krzysztofa Dobińskiego. 
Bonifacius à S. Mathia $\mathrm{Fr}^{244}$, nat. 1657, prof. 1679, obit. 26.12.1708 Posnaniae.

Bonifacius à S. Norberto ARP, Gręca (Grentz) Norbertus ${ }^{245}$, ex Prior Gedanensis et Trutoviensis, ex professor, actualis magister novitiorum, nat. 07.06.1758, prof. 10.06.1776 Gedani, presb. 13.06.1782 Varsaviae, obit. 06.09.1826 Trutoviae.

Bonifacius à S. Venantio RP, Fischer Petrus ${ }^{246}$, nat. 1713, prof. 25.05.1731, obit. 01.05.1747 Trutoviae.

Brocardus à S. Adalberto RP, Moczynski Adalbertus ${ }^{247}$, nat. 31.03.1754, prof. 14.03.1775 Gedani, presb. 25.04.1779 Plonscii.

Brocardus à S. Antonio Kilanowski RP ${ }^{248}$, nat. 1837, prof. 1860, presb. 1861, obit. 21.09.1865 in villa Trzebiegoszcz, sepultus in Sumin.

Brocardus à S. Bartholomaeo $\mathrm{Fr}^{249}$, nat. 1649, prof. 1679, obit. 07.07.1709 Posnaniae.

Brocardus à S. Eliseo $\mathrm{Fr}^{250}$, centenarius, nat. 1625, obit. 20.01.1705 Gedani.

Brocardus à S. Francisco Fr, Szcholtzt Franciscus ${ }^{251}$, sartor, musicus, vocalista et pro conventu Varsaviensi quaestiarius bene meritus, nat. 05.04.1720, prof. 04.09.1748 Posnaniae, obit. 13.11.1775 Varsaviae.

Brocardus à S. Georgio Frost RP 252 , nat. 1774, prof. 1791, presb. 1797, obit. 03.10.1819 Trutoviae.

Brocardus à S. Stanislao RP, Sebastyanski Petrus ${ }^{253}$, ex lector philosophiae, concionator Polonorum, nat. 17.07.1726, prof. 02.08.1750 Posnaniae, presb. 05.05.1754 Posnaniae, obit. 27.02.1774 Lipiae.

Brocardus ab Ascensione Domini ARP ${ }^{254}$, ex prior Kcynensis, nat. 1660, prof. 1685, obit. 09.06.1709 Lipiae.

Brocardus ab Ascensione Domini ARP, Jarząbkowski Mathias ${ }^{255}$, prior variis conventibus, nat. 19.02.1679, prof. 20.05.1706, obit. 11.06.1749 Plonscii.

Bruno à S. Casimiro $\mathrm{Fr}^{256}$, nat. 1675, prof. 1694, obit. 03.01.1707 Bidgostiae.

${ }^{244}$ AKKr 175/547, s. 725; Zak. 66.

${ }^{245}$ AKKr 174/614, s. 14-15; AKKr 175/547, s. 503; Zak. 66; T. Nowicki, Stownik biograficzny rządców parafii Archidiakonatu Pomorskiego w XVIII wieku, Lublin 2003, s. 77: w 1797 był komendariuszem w Niedamowie. W 1799 przeor w Gdańsku.

${ }^{246}$ AKKr 174/614, s. 31; Kart. 27, s. 411: brak pełnej daty urodzenia; AKKr 175/547, s. 243; Zak. 66; Zak. 61, s. 121; AAG, ACon G II 4, s. 10v: członek konwentu w Kcyni w 1739. Święcenia prezbiteratu otrzymał 25 października 1739 w kaplicy Potockich w katedrze w Gnieźnie z rąk sufragana gnieźnieńskiego Krzysztofa Dobińskiego.

${ }^{247}$ AKKr 174/614, s. 14-15.

${ }^{248} \mathrm{AKKr} 175 / 547$, s. 533.

${ }^{249}$ AKKr 175/547, s. 379; Zak. 66; Zak. 61, s. 188.

${ }^{250}$ AKKr 175/547, s. 39; Zak. 66; Zak. 61, s. 20.

${ }^{251}$ AKKr 174/614, s. 22-23 i 39; AKKr 175/547, s. 639; Zak. 66; Zak. 61, s. 309: prawidłowo nazwisko w formie Scholtz.

${ }^{252}$ AKKr 175/547, s. 557; Zak. 66.

${ }^{253}$ AKKr 174/614, s. 6-7 i 39; AKKr 175/547, s. 5; Zak. 66; Zak. 61, s. 58; Kroniczka, s. 81, 86, 90, 104-106, 109, 111, 118-119, 122, 132-134, 151, 156-157 i 195: mistrz nowicjatu w klasztorze Bożego Ciała w Poznaniu. Prezydent rezydencji przy kościele Najświętszej Krwi Pana Jezusa w Poznaniu w latach 1766-1769. Po rezygnacji w listopadzie 1769 powrócił do klasztoru Bożego Ciała w Poznaniu.

${ }^{254}$ AKKr 175/547, s. 321; Zak. 66.

${ }^{255}$ AKKr 174/614, s. 32; Kart. 27, s. 407; Zak. 61, s. 162.

${ }^{256} \mathrm{AKKr}$ 175/547, s. 5; Zak. 66; Zak. 61, s. 4: podana data zgonu 4 stycznia 1707. 
Bruno à S. Francisco RP, Szreder (Schröder) Michael $^{257}$, nat. 05.09.1723, prof. 08.10.1744 Gedani, presb. 20.12.1749 Varsaviae, obit. 21.04.1791 Trutoviae.

Bruno à S. Joanne $\mathrm{Fr}^{258}$, nat. 1655, prof. 1678, obit. 16.06.1707 Bidgostiae.

Bruno à S. Maria $\mathrm{Fr}^{259}$, terminarius, nat. 1685, prof. 1711, obit. 10.02.1726 Kcynae.

Bruno à $S$. Michaele $\rightarrow$ Benno à $S$. Michaele

Bruno à S. Michaele Szalwiński RP ${ }^{260}$, professor clericorum, postea administrator in Spetal, nat. 1832, obit. 10.08.1872 Varsaviae. Miles.

Caelestinus à S. Josepho RP, Sarnowski Josephus ${ }^{261}$, nat. 01.1768, prof. Gedani

Caelestinus à S. Michaele RP, Kruczkowski Michael ${ }^{262}$, nat. 27.09.1745, prof. 27.05.1762 Gedani, presb. 02.09.1770 Trutoviae, obit. 29.02.1780 Drohobiciis.

Caelestinus à SS. Trinitate Fr, Sadowicz Paulus ${ }^{263}$, sartor et terminarius, nat. 24.03.1737, prof. 30.05.1766 Posnaniae, obit. 08.01.1798 Plonscii.

Caelestinus ab Ascensione Domini RP, Schütz Benjamin ${ }^{264}$, musicus eximius, sacrista, nat. 25.02.1711, prof. 21.05.1739, obit. 02.10.1758 Gedani.

Cajetanus à S. Andrea RP, Chrostowski Andreas ${ }^{265}$, nat. 26.11.1703, prof. 10.08.1722.

Cajetanus à S. Joanne RP, Robaszkiewicz Joannes ${ }^{266}$, nat. 07.06.1731, prof. 13.08.1753 Gedani, presb. 16.04.1758 Posnaniae, obit. 29.04.1802 Lipiae.

Cajetanus à S. Mathia Fr, Sikorski Mathias ${ }^{267}$, nat. 25.02.1745, prof. 14.08.1773 Gedani, obit. 31.01.1780 Plonscii.

Cajetanus à $\mathrm{S}$. Michaele $\rightarrow$ Cajetanus à $\mathrm{S}$. Mathia

Cajetanus à S. Raymundo Fr, Kreczmer Martinus ${ }^{268}$, sartor, dispensator, terminarius, nat. 07.11.1690, prof. 01.09.1716, obit. 30.12.1760 Plonscii.

Cajetanus Schroeder ARP ${ }^{269}$, ex provincialis, ex prior decennalis Trutoviensis, triennalis Oboriensis, Varsaviensis, Klodaviensis, Guloviensis et Vąsosensis, ex definitor et

${ }^{257}$ AKKr 174/614, s. 4-5; Kart. 27, s. 414; AKKr 175/547, s. 223; Zak. 66; Zak. 61, s. 111: podana data zgonu 21 kwietnia 1790.

${ }^{258}$ AKKr 175/547, s. 337; Zak. 66; Zak. 61, s. 167.

${ }^{259} \mathrm{AKKr}$ 175/547, s. 81; Zak. 66; Zak. 61, s. 41: podana data zgonu 10 lutego 1727; Z 61, s. 42: zapis przekreślony.

${ }^{260} \mathrm{AKKr} 175 / 547$, s. 447.

${ }^{261}$ AKKr 174/614, s. 16-17.

${ }^{262}$ AKKr 174/614, s. 8-9 i 41: podana data zgonu 20 lutego 1780; Zak. 66; AKKr 175/547, s. 119 i 85: podana data zgonu 12 lutego 1780; Zak. 61, s. 59; ADP, C 54a, s. 78: członek konwentu w Trutowie w 1770. Święcenia subdiakonatu otrzymał 9 czerwca 1770, diakonatu 1 lipca 1770 i prezbiteratu 5 sierpnia 1770 w Chełmży z rąk sufragana chełmińskiego Franciszka Fabiana Pląskowskiego.

${ }^{263}$ AKKr 174/614, s. 24-25; Zak. 66; Zak. 61, s. 8.

${ }^{264}$ AKKr 174/614, s. 34; Kart. 27, s. 412; AKKr 175/547, s. 555; Zak. 66; Zak. 61, s. 267; Zakonnicy, s. 335.

${ }^{265}$ Kart. 27, s. 410.

${ }^{266}$ AKKr 174/614, s. 6-7; Zak. 66; Zak. 61, s. 119.

${ }^{267}$ AKKr 174/614, s. 26-27 i 41; AKKr 175/547, s. 61; Zak. 66; Zak. 61, s. 31: podane imiona zakonne Cajetanus à S. Michaele.

${ }^{268}$ AKKr 174/614, s. 35; Kart. 27, s. 414; AKKr 175/547, s. 733; Zak. 66.

${ }^{269}$ AKKr 175/547, s. 519 (zapis został do druku skrócony); ADWł, Zak. 12, s. 14 i 14v (d i p): syn Antoniego. Członek konwentu w Poznaniu w 1817. Święcenia subdiakonatu otrzymał 28 wrze- 
custos provinciae, ex magister novitiorum, nat. 1792, prof. 1815, presb. 1817, obit. 14.09.1871 Oboriis.

Camillus à S. Francisco RP, Stefanski Franciscus ${ }^{270}$, nat. 08.10.1774.

Candidus à S. Adalberto Fr, Drzewiecki Adalbertus ${ }^{271}$, clericus perpetuus, organarius, choralis, nat. 22.04.1747, prof. 11.09.1768 Posnaniae, obit. 14.04.1818 Trutoviae.

Candidus à S. Matheo RP $\mathrm{P}^{272}$, studens theologiae, nat. 1708, prof. 1728, obit. 18.09.1735 Posnaniae.

Cantius à S. Ignatio ARP, Weychan Ignatius ${ }^{273}$, concionator Polonorum, prior annis 10 loci, nat. 13.07.1740, prof. 28.06.1761 Posnaniae, presb. 28.07.1764 Kcynae, obit. 24.09.1788 Drohobiciis.

\section{Cantius à $\mathrm{S}$. Joanne $\rightarrow$ Cantius à $\mathrm{S}$. Ignatio}

Cantius à S. Josepho RP, Parchiem Josephus ${ }^{274}$, ex carmelita, praepositus Lubovidzensis ultimo Działenensis, nat. 1772, obit. 17.03.1852 Działeń.

Cantius à S. Juliano RP, Gałęski Simon ${ }^{275}$, poeta extemporaneus, orator eximius, metro plurima scripsit. 12 annis professor rethorices, concionator insignis, eius opera mul-

śnia 1817, diakonatu 5 października 1817 i prezbiteratu 12 października 1817 w Lądzie z rąk tamtejszego opata i sufragana gnieźnieńskiego Antoniego Raczyńskiego.

${ }^{270}$ AKKr 174/614, s. 20.

${ }^{271}$ AKKr 174/614, s. 10-11; AKKr 175/547, s. 209; Zak. 66.

${ }^{272}$ AKKr 175/547, s. 527; Zak. 66; Zak. 61, s. 253.

${ }^{273}$ AKKr 174/614, s. 8-9; AKKr 175/547, s. 539; Zak. 66; Zak. 61, s. 259.

${ }^{274}$ AKKr 174/614, s. 20; AKKr 175/547, s. 153: Lubowidz i Działyń w diecezji płockiej.

${ }^{275}$ AKKr 174/614, s. 35: podana data zgonu 5 maja 1760; Kart. 27, s. 411; AKKr 175/547, s. 253; Zak. 66; Zak. 61, s. 125: podana data zgonu 5 maja 1760; Bibliografia Polska. T. 14, Stólecie XV-XVIII, Część 3 T. 3 lit. C, przez K. Estreichera, Kraków 1896, s. 47-48: opublikował: Capitolium extra Romam Virtutum, Scientiae, Meritorum Primis Capitibus Coronatum Triumphalibus Laurearum Sertis adornatum Gentilitiique armis Perillustris et Reverendissimi Domini DN. Vladislai Josephi de Wyczechowo Wyczechowski Canonici Cathedralis Vladislaviensis, Ejusdemque Iilustrissimi Capituli Generalis Commissarii, Raciażensis Srzynensis etc. Praepositi Domini et Mecoenatis Gratiosissimi praemunitum. Sub tempus Venerabilis Capituli Provincionalis, Ordinis Fratrum Beatissimae Dei Genitricis, semperque Virginis Mariae de Monte Carmelo Strictioris Observantiae, in Conventu Kcynensi celebrati, Oratoria ab exedra patefactum. Per P. Cantium a S. Juliano, Ordinis ejusdem Studii Rhetorici Professorem. Anno quo aeternales Portas ingressus est Rex gloriae 1742. fol. str. 32. Na odwrotnej stronie herb Wyczechowskich z 12 wierszami. Dalej dedykacya Wyczechowskiemu na 4 kartach i rzecz cała na 22 str. in folio; Novum Emergens ex oculis Lachrymosae virginis etc. Thorunii, 1757. folio. Dedic. Mariae Reginae dolorum et Poloniae; Occasus solis circa Auroram in benigno Arietis signo perillustris \& reverendissimi domini D. Augustini Thaddaei de Klincz von Rautenberg Kliński, decani Culmensis, archidiaconi per Pomeraniam Vladislav. catech. canonici et praelati praepositi Mariaeburgensis, doctoris utriusque juris domini et mecoenatis colendissimi demonstratus seu funestus Dei hominis sub ligno casus in ligno occasus parentante deipara Maria Virgine festo eiusdem dolorosae \& prodigiosae matris, in ecclesia Carmeli Oboriensis flebili orationis stylo ad memoriam cordium annotatus per p. Cantium a S. Juliano, ordinis Fratrum B. V. M. de Monte Carmelo strictioris observantiae provinciae Majoris Poloniae Ssmi Sacramenti alumnum, in Carmelo Oboriensi actualem eloquentiae professorem. Perorante e suggestu in cogressu dignissimorum hospitum F. Ludovico a S. Hyacintho eiusdem ordinis Professo rhetorices auditore.Annoquo-SoLIs InoCCasVLVXItCastIssIMaVIrgo-EtfLetVtantoperItsoLatIaCVnCtIs. (1744). fol. 10 k. nlb. Dedic. Aug. Thad. Klinski decano Culm; Partus ingenii Mariani facilis, quia momentaneus et mirabilis; maximis tamen in doloribus D. Dismas latro poenitens. Thorunii. B. w. roku. fol; 
tae Panegyres, ac 18 conciones Polonon. de S. Joanne Nepomuceno luce fruuntur publica, nat. 04.11 .1714 , prof. 13.10 .1732 , obit. 06.05.1760 Oboriis.

Capistranus à S. Cypriano ARP, Moraczewski Josephus ${ }^{276}$, ex prior Klodaviensis, subprior loci, nat. 17.03.1711, prof. 01.10.1733 Gedani, presb. 30.09.1738 Varsaviae, obit. 16.07.1774 Gedani.

Capistranus à S. Josepho RP, Konka Josephus ${ }^{277}$, studens theologiae, nat. 06.03.1770, prof. 18.10.1786 Gedani, presb. 20.10.1793 Plonscii, obit. 28.04.1795 Plonscii.

Caprasius à Monte Carmeli $\mathrm{Fr}^{278}$, clericus perpetuus, organarius, choralis, nat. 1671, prof. 1693, obit. 08.04.1737 Oboriis.

Caprasius à S. Francisco Fr, Sztoltz Franciscus ${ }^{279}$, sartor, nat. 1746, prof. 29.12.1772 Posnaniae, obit. 12.10.1804 Plonscii.

Carolus à S. Bartholdo RP, Więckowski Alexius ${ }^{280}$, nat.10.07.1710, prof. 26.05.1729, obit. 18.12.1752 Trutoviae.

Carolus à S. Bartholomaeo ARP, Broszkowski Joannes ${ }^{281}$, STL, jubilatus, orator et theologus scientiis solidus, ac in gravitate sensuum clarus, ex prior Oboriensis, bis ex definitor, theologiae dogmaticae professor, nat. 24.06.1703, prof. 25.08.1729, presb. 1731, obit. 09.05.1759 Kcynae.

Carolus à S. Francisco Freymark $\mathrm{Fr}^{282}$, terminarius, bene commendatus, nat. 1738, prof. 1777, obit. 10.06.1808 Kcynae.

Carolus à S. Laurentio Fr, Zielewicz Laurentius ${ }^{283}$, nat. 26.10.1743, prof. 05.11.1776 Gedani, obit. 25.04.1790 Gedani.

Pole pierwsze kaznodzieyskie Wielkiemu Tryumfatorowi Panowi nieprzyiaznych języków zwycięzcy Nepomucenowi s. Kanonikowi Katedralnemu Praskiemu z powinnej obligacyi poświęcone przez Karmelitę ściślejszej obserwacyi, Prowincji Wielkopolskiey Kapłana, Kaznodzieję Ordynarjusza którego Imię jest w następujących wierszach: Jest za kolumna, król imienia mego - a ksiaże liter, pierwszy stuga iego - Na trzecie to mam, co pierwsze nikomu - Ty wreszcie przyday, juściż jesteś $w$ domu. Roku którego Pan zwycięzca, śmierć i piekło w pole wywiódt 1752. W Poznaniu w druk. akadem. w 4ce, k. 2. str. 204. k. 4 oraz Septem ut octo dolores Mariani Cordis recuperante septem numerorum anno et annua macroris huius memoria ad aedes dolorosissimae Virginis in ecclesia Oboriensi. Thorunii 1747. folio kartki nieliczb. Dedyk. Mathiae Josepho Stanislao Gostomski Canonico Crusvicensi.

${ }^{276}$ AKKr 174/614, s. 2-3 i 39: na s. 3 podana data zgonu 15 lipca 1774; Kart. 27, s. 412; AKKr 175/547, s. 397; Zak. 66; Zak. 61, s. 197: podana data zgonu 16 lipca 1775; ADP, A 16, s. 61: święcenia prezbiteratu otrzymał 29 września 1738 w kościele reformatów w Toruniu-Podgórzu z rąk sufragana chełmińskiego Macieja Aleksandra Sołtyka; Zakonnicy, s. 335.

${ }^{277}$ AKKr 174/614, s. 18-19; AKKr 175/547, s. 245: podana data zgonu 2 maja 1795; Zak. 66; Zak. 61, s. 118.

${ }^{278}$ AKKr 175/547, s. 197; Zak. 66; Zak. 61, s. 98.

${ }^{279}$ AKKr 174/614, s. 26-27; AKKr 175/547, s. 633: podana data zgonu 10 listopada 1804 i nazwisko Szultz; Zak. 66; Zak. 61, s. 277.

${ }^{280}$ AKKr 174/614, s. 33: podane miejsce zgonu Płońsk; Kart. 27, s. 410; AKKr 175/547, s. 709; Zak. 66.

${ }^{281}$ AKKr 174/614, s. 34; Kart. 27, s. 410; AKKr 175/547, s. 259; Zak. 66; Zak. 61, s. 129.

${ }^{282} \mathrm{AKKr}$ 175/547, s. 391: podana data zgonu 13 lipca 1807; Zak. 66; Zak. 61, s. 191: podana data zgonu 10 lipca 1807.

${ }^{283}$ AKKr 174/614, s. 26-27; AKKr 175/547, s. 281: podana data zgonu 20 maja 1790; Zak. 66; Zak. 61, s. 114: podana data zgonu 24 kwietnia 1790; Zakonnicy, s. 336. 
Carolus à S. Leonardo Fr, Morzychowski Joannes ${ }^{284}$, scrinifaber, nat. 24.02.1714, prof. 06.02.1743, obit. 07.03.1761 Trutoviae.

Carolus à S. Michaele ARP, Klawanski Michael ${ }^{285}$, STL, ex provincialis, ex prior Varsaviensis et Oboriensis, actualis prior loci, nat. 25.09.1740, prof. 19.11.1761, presb. 11.11.1764 Bidgostiae, obit. 24.03.1797 Lipiae.

Carolus à S. Michaele Fr, Cynal Michael ${ }^{286}$, nat. 26.09.1743, prof. 06.11.1766 Gedani, obit. 11.06.1774 Drohobiciis.

Carolus à S. Petro ARP ${ }^{287}$, ex concionator Polonorum, prior loci, nat. 1669, prof. 1688, obit. 13.03.1726 Oboriis.

Carolus à Venerabili Sacramento RP ${ }^{288}$, nat. 1669, prof. 1687, obit. 31.03.1707 Oboriis.

Carolus Malich $\mathrm{Fr}^{289}$, clericus sollemniter professus, infelici casu ab undis Vistulae circa Bielany arreptus mortem oppetit, nat. 1910, obit. 27.07.1933 Cracoviae.

Casimirus à Matre Amabili RP ${ }^{290}$, nat. 1640, prof. 1659, obit. 01.03.1700 Bidgostiae.

Casimirus à S. Adalberto $\mathrm{Fr}^{291}$, clericus, studens philosophiae, nat. 1729, prof. 1757, obit. 22.04.1760 Bidgostiae.

Casimirus à S. Alberto (Adalberto) RP, Wołoszko Albertus ${ }^{292}$, procurator, nat. 18.04.1701, prof. 12.03.1719, obit. 05.10.1751 Bidgostiae.

Casimirus à S. Alberto $\mathrm{Fr}^{293}$, seniculus, obit. 16.02.1757 Bidgostiae.

Casimirus à S. Andrea Fr, Rafałowicz Andreas ${ }^{294}$, nat. 1689, prof. 01.04.1711, obit. 16.02.1757 Bidgostiae.

${ }^{284}$ AKKr 174/614, s. 35: data zgonu 4 marca 1761; Kart. 27, s. 416; AKKr 175/547, s. 133; Zak. 66; Zak. 61, s. 66.

${ }^{285}$ AKKr 174/614, s. 8-9; AKKr 175/547, s. 167 i 177: podana druga data zgonu 29 marca 1797; Zak. 66; Zak. 61, s. 88: podana data zgonu 29 marca 1797; ADP, C 54a, s. 59 i 60: członek konwentu w Bydgoszczy w 1764. Tonsurę i niższe święcenia otrzymał 22 września 1764, subdiakonatu 28 października 1764, diakonatu 1 listopada 1764 i prezbiteratu 4 listopada 1764 w Chełmży. Szafarzem wszystkich święceń był sufragan chełmiński Franciszek Fabian Pląskowski.

${ }^{286}$ AKKr 174/614, s. 24-25 i 39; AKKr 175/547, s. 325; Zak. 66; Zak. 61, s. 163: podana data zgonu 12 czerwca 1774.

${ }^{287}$ AKKr 175/547, s. 145; Zak. 66; Zak. 61, s. 72: podana data zgonu 13 marca 1727.

${ }^{288}$ AKKr 175/547, s. 181; Zak. 66; Zak. 61, s. 90; ADP, A 41, s. 5v, 10 i 10v: członek z konwentu w Oborach w latach 1691-1693. Tonsurę i niższe święcenia oraz święcenia subdiakonatu otrzymał 31 marca 1691, diakonatu 19 września 1693 i prezbiteratu 19 grudnia 1693 w katedrze w Chełmży. Szafarzem wszystkich święceń był sufragan chełmiński Tomasz Skotnicki.

${ }^{289}$ AKKr 175/547, s. 419.

${ }^{290}$ AKKr 175/547, s. 121; Zak. 66; Zak. 61, s. 60.

${ }^{291}$ AKKr 174/614, s. 35; AKKr 175/547, s. 227; Zak. 66; Zak. 61, s. 113: podana data zgonu 23 kwietnia 1760.

${ }^{292}$ AKKr 174/614, s. 32; Kart. 27, s. 409; AKKr 175/547, s. 561; Zak. 66; Zak. 61, s. 270; AAG, ACap B 79, s. 46: członek konwentu w Markowicach w 1726. Święcenia prezbiteratu otrzymał 28 października 1726 w kościele parafialnym w Kamieńcu z rąk sufragana gnieźnieńskiego Franciszka Kraszkowskiego.

${ }^{293}$ AKKr 174/614, s. 34

${ }^{294}$ Kart. 27, s. 414; AKKr 175/547, s. 93: podane imiona zakonne Casimirus à S. Joanne; Zak. 66: podane imiona zakonne Casimirus à S. Joanne; Zak. 61, s. 47. 
Casimirus à S. Andrea RP, Grabowski Andreas ${ }^{295}$, nat. 27.11.1744, prof. 22.12.1766 Gedani, presb. 15.10.1769 Posnaniae, Canonicus Regularis.

Casimirus à S. Ignatio Lewiński $\mathrm{Fr}^{296}$, emeritus, bene meritus, nat. 1768, prof. 1791, obit. 23.12.1835 Klodaviae.

Casimirus à S. Jacobo $\mathrm{Fr}^{297}$, clericus novitius, qui pridie obitus omnibus moribundorum Sacramentis munitus, ad sacram professionem admissus est, nat. 1751, obit. 27.11.1788 Posnaniae.

Casimirus à S. Joanne $\rightarrow$ Casimirus à S. Andrea

Casimirus à S. Joanne Baptista RP, Jordan Jacobus ${ }^{298}$, ex presbyter saecularis, seniculus, organarius, choralis, nat. 07.07.1682, prof. 09.03.1712, obit. 14.11.1757 Lipiae.

Casimirus à S. Ludovico Koscinski $\mathrm{Fr}^{299}$, bene commendatus, in coligendis aelemosinis assiduus et ab omnibus amantissimus, nat. 1819, obit. 14.05.1852 Oboriis.

Casimirus à S. Paulo $\mathrm{RP}^{300}$, nat. 1682, prof. 1703, obit. 03.10.1710 Bidgostiae.

Casimirus à S.P.N. Elia RP ${ }^{301}$, subprior, nat. 1668, prof. 1687, obit. 14.09.1708 Varsaviae.

Casimirus Roman $\mathrm{ARP}^{302}$, pluribus annis prior loci laudabilis, novissimus e Conventu Wąsosiensi patrum antiquistarum [= antiquae observantiae], ex definitor, subprior loci, nat. 1765 , prof. 1795 , presb. 1800, obit. 30.08.1840 Wąsosiae.

Cassianus à S. Joanne Piasecki RP ${ }^{303}$, ex vicarius Lipiensis, olim capellanus Mogielnicensis et Goszczynensis, subprior loci, nat. 1795, prof. 1828, presb. 1831, obit. 18.04.1842 Oboriis.

Cassianus à S. Valentino ARP, Pokorzynski (Pokora) Valentinus ${ }^{304}$, ex prior Bidgostiensis et Markovicensis, nat. 20.02.1757, prof. 31.08.1775 Gedani, presb. 10.03.1781 Posnaniae, obit. 06.02.1826 Kcynae.

Ceslaus à S.P.N. Elia Fr, Cwiklinski Martinus ${ }^{305}$, clericus, studens philosophiae conventus nostri Bydgostiensis, nat. 14.11.1720, prof. 03.12.1743, obit. 04.08.1746 Neophaniae.

Ceslaus Wróblewski $\mathrm{Fr}^{306}$, nat. 1841, obit. 21.05.1921 Leopoli.

${ }^{295}$ AKKr 174/614, s. 10-11.

${ }^{296} \mathrm{AKKr}$ 175/547, s. 719; Zak. 66: podana data zgonu 24 grudnia 1835.

${ }^{297}$ AKKr 175/547, s. 667; Zak. 66: podana data zgonu 28 listopada 1788.

${ }^{298}$ AKKr 174/614, s. 34: podana data zgonu 19 listopada 1757; Kart. 27, s. 408; AKKr 175/547, s. 641 ; Zak. 66; Zak. 61, s. 310.

${ }^{299}$ AKKr 175/547, s. 269.

${ }^{300}$ AKKr 175/547, s. 557; Zak. 66; Zak. 61, s. 269: podana data zgonu 4 października 1710.

${ }^{301}$ AKKr 175/547, s. 519; Zak. 66; Zak. 61, s. 249.

${ }^{302}$ AKKr 175/547, s. 489; Zak. 66.

${ }^{303}$ AKKr 175/547, s. 217; Zak. 66.

${ }^{304}$ AKKr 174/614, s. 14-15; Zak. 66; AKKr 175/547, s. 117 i 625: data zgonu 28 lutego 1826 i 6 listopada 1826.

${ }^{305} \mathrm{AKKr}$ 174/614, s. 31: podana data zgonu 7 sierpnia 1746 w Pile dekanacie czarnkowskim diecezji poznańskiej; Kart. 27, s. 414; AKKr 175/547, s. 435; Zak. 66; Zak. 61, s. 214: podana data zgonu 2 sierpnia 1746 w Nowej Cerkwii.

${ }^{306} \mathrm{AKKr}$ 175/547, s. 283. 
Cherubinus à S. Antonio ARP, Nakielski Antonius ${ }^{307}$, STL, ex definitor, jubilatus ac geometriae peritus, vir sagacis ingenii, ex prior Gedanensis, actualis prior loci, nat. 07.02.1704, prof. 13.06.1720, obit. 13.04.1752 Bidgostiae.

Cherubinus à S. Antonio Fr, Zalewski Antonius ${ }^{308}$, terminarius, nat. 28.07.1723, prof. 24.12.1756 Gedani, obit. 26.12.1776 Oboriis.

Cherubinus à S. Josepho ARP, Walicki Josephus ${ }^{309}$, ex provincialis, pluribus annis procurator ac subprior loci, cuius industria capella secus conventum, vulgo in Calvaria, renovata, picturis exornata, Dominus Jesus in Cruce pendens innovatus, ac per ipsum qualibet feria sexta Missae Sacrificio celebrato, ac eleemosina in pauperes elargita, nat. 15.05.1735, prof. 22.02.1759 Posnaniae, presb. 20.07.1762 Bidgostiae, obit. 11.04.1806 Oboriis.

Cherubinus à Visitatione B.M.V. RP ${ }^{310}$, nat. 1666, prof. 1686, obit. 03.08 .1732 Oboriis.

Chrisologus à S. Constantino Sieradzki RP ${ }^{311}$, nat. 1798, prof. 1817, obit. 18.10.1829 Wąsosiae.

Chrisologus à S. Francisco ARP, Deryng Franciscus ${ }^{312}$, STL, provincialis, ex definitor, sex annis professor philosophiae et theologiae in Monasterio Pelplinensi Ordinis Cisterciensium, nat. 17.09.1767, prof. 13.01.1784 Gedani, presb. 18.09.1790 Varsaviae, obit. 02.03.1814 Plonscii.

Chrisologus à S. Martino RP, Skęmpski Martinus ${ }^{313}$, ex lector philosophiae, actualis concionator Oboriensis, nat. 12.11.1752, prof. 28.05.1770 Posnaniae, presb. 06.03.1776 Posnaniae, obit. 08.04.1782 Klodaviae.

Christianus à S. Joanne RP, Szanowski Joannes ${ }^{314}$, nat. 11.05.1761, prof. 13.12.1778 Gedani, presb. 03.10.1784 Varsaviae.

Christophorus à S. Ambrosio RP, Bajer Ambrosius ${ }^{315}$, musicus, nat. 02.03.1749, prof. 12.12.1769 Gedani, presb. 01.05.1773 Kcynae, obit. 28.01.1793 Kcynae.

Christophorus à S. Bartholomaeo RP ${ }^{316}$, nat. 1698, prof. 1716, obit. 13.06 .1738 Drohobiciis.

${ }^{307}$ AKKr 174/614, s. 32; Kart. 27, s. 409; AKKr 175/547, s. 207; Zak. 66; Zak. 61, s. 103; AAG, ACap B 79, s. 53: członek konwentu w Poznaniu w 1728. Święcenia prezbiteratu otrzymał 11 stycznia 1728 w kaplicy seminarium w Gnieźnie z rąk sufragana gnieźnieńskiego Franciszka Kraszkowskiego.

${ }^{308}$ AKKr 174/614, s. 22-23 i 39; Zak. 66.

${ }^{309}$ AKKr 174/614, s. 8-9; AKKr 175/547, s. 203; Zak. 66; Zak. 61, s. 101; ADWł, ABSWł 10, s. 12, 15 i 17: członek konwentu w Bydgoszczy w latach 1761-1762. Tonsurę i niższe święcenia otrzymał 28 października 1761 w kościele klarysek w Bydgoszczy, święcenia subdiakonatu 4 marca 1762, diakonatu 6 marca 1762 i prezbiteratu 12 lipca 1762 w katedrze we Włocławku. Szafarzem wszystkich święceń był sufragan włocławski Jan Dembowski.

${ }^{310} \mathrm{AKKr}$ 175/547, s. 433; Zak. 66; Zak. 61, s. 213: podana data zgonu 1 sierpnia 1732.

${ }^{311}$ AKKr 175/547, s. 587.

${ }^{312}$ AKKr 174/614, s. 16-17; AKKr 175/547, s. 123; Zak. 66: podana data zgonu 1 marca 1814.

${ }^{313}$ AKKr 174/614, s. $12-13$ i 41: na s. $12-13$ podana data zgonu 14 kwietnia 1782; AKKr 175/547, s. 199; Zak. 66; Zak. 61, s. 99.

${ }^{314}$ AKKr 174/614, s. 14-15.

${ }^{315}$ AKKr 174/614, s. 12-13; AKKr 175/547, s. 55; Zak. 66; Zak. 61, s. 28.

${ }^{316}$ AKKr 175/547, s. 329; Zak. 66; Zak. 61, s. 164. 
Christophorus à S. Gertrude $\mathrm{Fr}^{317}$, terminarius bene meritus, nat. 1666, prof. 1691, obit. 26.12.1740 Posnaniae.

Christophorus à S. Jacobo Fr, Lęsicki Jacobus ${ }^{318}$, terminarius, seniculus, nat. 1703, prof. 13.08.1744 Posnaniae, obit.02.02.1765 Posnaniae.

Christophorus à S. Jacobo $\mathrm{Fr}^{319}$, nat. 1703, prof. 1735, obit. 03.01.1749 Posnaniae.

Christophorus à S. Josepho $\mathrm{Fr}^{320}$, nat. 1628, prof. 1649, obit. 26.04.1681 Posnaniae.

Christophorus à S. Laurentio $\rightarrow$ Chrysostomus à S. Laurentio

Christophorus à SS. Trinitate RP, Schneider Joannes ${ }^{321}$, organarius et exorcista, nat. 10.08.1706, prof. 20.05.1732, presb. 1733, obit. 27.10.1761 Kcynae.

Chrysostomus à S. Adalberto ARP, Polejowski Adalbertus ${ }^{322}$, STL, ex prior Plonscensis, ac definitor provinciae, nat. 01.04.1731, prof. 31.08.1750 Gedani, presb. 25.01.1756 Varsaviae, obit. 19.11.1798 Lipiae.

Chrysostomus à S. Bartholomaeo RP ${ }^{323}$, nat. 1669, prof. 1692, obit. 21.02.1738 Drohobiciis.

Chrysostomus à S. Laurentio RP, Czapski Stanislaus ${ }^{324}$, ex lector philosophiae, subprior loci, nat. 06.07.1701, prof. 12.02.1723, obit. 06.08.1749 Gedani.

Chrysostomus à S. Teresia $\mathrm{Fr}^{325}$, nat. 1718, prof. 1750, obit. 06.03.1773 Trutoviae.

Clemens à S. Andrea ARP, Boruski (Merucki) Andreas ${ }^{326}$, jubilatus, concionator Polonorum, ex prior Lipienensis, Posnaniensis, Gedanensis et Markovicensis, ex definitor, ex praeses capituli Klodaviensis, actualis 2do prior loci, exsolvit debitum mortalilati, transiens ad immortilitem, nat. 29.11.1708, prof. 01.12.1724, presb. 1729, obit. 22.03.1770 Markovicae.

${ }^{317}$ AKKr 175/547, s. 725; Zak. 66.

${ }^{318}$ AKKr 174/614, s. 22-23 i 36: podana na s. 36 data zgonu 7 grudnia 1765; AKKr 175/547, s. 65; Zak. 66; Zak. 61, s. 33.

${ }^{319}$ AKKr 175/547, s. 5: podana data zgonu 3 stycznia 1740; Zak. 66; Zak. 61, s. 3.

${ }^{320}$ AKKr 175/547, s. 233; Zak. 66; Zak. 61, s. 116.

${ }^{321}$ AKKr 174/614, s. 35; Kart. 27, s. 411; AKKr 175/547, s. 603; Zak. 66; Zak. 61, s. 291: podana data zgonu 26 października 1761.

${ }^{322}$ AKKr 174/614, s. 6-7; Zak. 66; Zak. 61, s. 329: podana data zgonu 3 grudnia 1798; Kroniczka, s. 53, 67, 77, 90, 106, 122, 128, 132, 134-135 i 193: kaznodzieja zwyczajny w klasztorze Bożego Ciała w Poznaniu w 1765, a od 1766 lektor teologii. Skierowany do rezydencji przy kościele Najświętszej Krwi Pana Jezusa w Poznaniu w marcu 1768. W maju 1768 udał się do Bydgoszczy jako kaznodzieja.

${ }^{323}$ AKKr 175/547, s. 103; Zak. 66; Zak. 61, s. 52; ADP, A 41, s. 12v: święcenia subdiakonatu otrzymał 26 lutego 1695 w katedrze w Chełmży z rąk sufragana chełmińskiego Tomasza Skotnickiego.

${ }^{324}$ AKKr 174/614, s. 32; Kart. 27, s. 410; AKKr 175/547, s. 439; Zak. 66: podana data zgonu 7 sierpnia 1749 i imiona zakonne Christophorus à S. Laurentio; Zakonnicy, s. 334: podane imiona Joannes Chrysostomus à S. Laurentio; Reszel, Bd.16, H.46, Braunsberg 1906, s. 192 (wpis nr 2404); G. Kloskowski, Sylwetki ..., s.247: syn Wawrzyńca i Anny Radomskiej. Od 1718 kształcił się w gimnazjum jezuickim w Reszlu. Brat opata pelplińskiego Leopolda Ignacego Franciszka Czapskiego (1708-1751).

${ }^{325}$ AKKr 174/614, s. 38: podana data zgonu 13 marca 1773; AKKr 175/547, s. 131; Zak. 66; Zak. 61, s. 65.

${ }^{326}$ AKKr 174/614, s. 37; Kart. 27, s. 410; AKKr 175/547, s. 163; Zak. 66; Zak. 61, s. 81. 
Clemens à S. Andrea Fr, Kozłowski Ludovicus ${ }^{327}$, terminarius, sartor, nat. 19.08.1706, prof. 08.12.1728, obit. 12.04.1755 Dobrynii.

Clemens à S. Catharina RP ${ }^{328}$, nat. 1635 , prof. 1653, obit. 06.01.1681 Posnaniae.

Clemens à S. Francisco $\mathrm{Fr}^{329}$, organarius, choralis, nat. 1726, prof. 1756, obit. 23.07.1763 Lipiae.

Clemens à S. Josepho Fr, Boruski Josephus ${ }^{330}$, pictor, nat. 13.03.1757, prof. 25.10.1784 Gedani, obit. 22.11.1795 Klodaviae.

Clemens à S. Josepho RP, Peterr Josephus ${ }^{331}$, nat. 13.01.1755, prof. 14.08.1772 Gedani, presb. 19.04.1778 Varsaviae.

Clemens à S. Pontiano ARP, Pilarski Laurentius ${ }^{332}$, ex prior Drohobicensis, ex presbyter saecularis, octo annis concionator Polonorum, magister novitiorum, jubilatus, nat. 04.08.1701, presb. 1726, prof. 11.10.1732, obit. 05.03.1770 Posnaniae, in capella Sanguinis Christi.

Clemens à S. Pontiano Kunigk ARP ${ }^{333}$, STL, jubilatus, in scientiis optime eruditus, tam in nostris scholis, quam in Monasterio Oliviensi Sacri Ordinis Cisterciensis, egregium egit professorem, eiusdem discipuli in doctos excrevere viros, sexennalis ex prior Gedanensis, nat. 1668, prof. 1692, obit. 16.08.1723 Gedani.

Clemens à S. Rocho RP, Dobrowolski Rochus ${ }^{334}$, nat. 23.08.1751, prof. 05.11.1776 Posnaniae, presb. 20.02.1780 Klodaviae, obit. 30.07.1800 Trutoviae.

Clemens à S. Stanislao Zawacki Fr ${ }^{335}$, clericus novitius, nat. 1836, obit. 11.06.1857 Oboriis.

Clemens Kowalkowski Fr ${ }^{336}$, nat. 1776, prof. 1834, obit. 30.04.1843 Varsaviae.

Columbanus à Praesentatione B.M.V. RP ${ }^{337}$, nat. 1641, prof. 1664, obit. 02.12.1690 Oboriis.

${ }^{327}$ AKKr 174/614, s. 33; Kart. 27, s. 415; AKKr 175/547, s. 239; Zak. 66; Zak. 61, s. 119: podana data zgonu 29 kwietnia 1755.

${ }^{328}$ AKKr 175/547, s. 11; Zak. 66; Zak. 61, s. 6.

${ }^{329}$ AKKr 174/614, s. 36; AKKr 175/547, s. 411; Zak. 66; Zak. 61, s. 204.

${ }^{330} \mathrm{AKKr}$ 174/614, s. 26-27; AKKr 175/547, s. 657; Zak. 66; Zak. 61, s. 319: podana data zgonu 23 listopada 1795

${ }^{331}$ AKKr 174/614, s. 12-13; ADP, C 54a, s. 124 (podane imiona Franciszek Klemens od Św. Józefa) i 125: członek konwentu w Gdańsku w latach 1775-1776. Tonsurę i niższe święcenia otrzymał 25 maja 1775 w kościele św. Wojciecha pod Gdańskiem, święcenia subdiakonatu 2 marca 1776 w kościele karmelitów w Gdańsku z rąk sufragana chełmińskiego Franciszka Fabiana Pląskowskiego.

${ }^{332}$ AKKr 174/614, s. 37: podana data zgonu 5 marca 1769; Kart. 27, s. 411; AKKr 175/547, s. 129; Zak. 66; Zak. 61, s. 64: podana data zgonu 5 marca 1769; Kroniczka, s. 138, 141, 146, 157, 158, 161, 163 i 188: przybył do rezydencji w Poznaniu z Gdańska w czerwcu 1768. Podana data zgonu 4 marca 1769.

${ }^{333}$ AKKr 175/547, s. 459; Zak. 66; Zakonnicy, s. 333; Kroniczka, s. 6 i 198: lektor św. teologii w klasztorze Bożego Ciała w Poznaniu w 1702.

${ }^{334}$ AKKr 174/614, s. 14-15; Zak. 66; ADWł, ABSWł 10, s. 67: członek konwentu w Kłodawie w 1780. Święcenia prezbiteratu otrzymał 2 lutego $1780 \mathrm{w}$ katedrze we Włocławku z rąk sufragana włocławskiego Jana Dembowskiego.

${ }^{335}$ AKKr 175/547, s. 325.

${ }^{336}$ AKKr 175/547, s. 241.

${ }^{337}$ AKKr 175/547, s. 677; Zak. 66; Zak. 61, s. 328. 
Columbanus à S. Anna RP, Darewski Jacobus ${ }^{338}$, nat. 30.09.1714, prof. 29.04.1733, presb. 1739, obit. 04.07.1762 Drohobiciis.

Columbanus à S. Joanne RP, Deryng Joannes ${ }^{339}$, concionator Polonorum, nat. 15.05.1757, prof. 22.11.1774 Gedani, presb. 08.10.1780 Gedani, obit. 26.08.1795 Kcynae.

Columbanus à S. Ladislao Zuchowski $\mathrm{ARP}^{340}$, ex provincialis, ex custos provinciae, ex praeses capituli, ex prior Plonscensis, definitor provinciae, vir exemplaris et devotus, qui ab anno 1831 nunquam integre sanus et saepe afflictus gravi infirmitate, cum resignatione hanc crucem patienter ut servus Christi passus est, nat. 1805, prof. 1826, presb. 1830 , obit. 02.05.1854 Plonscii.

Columbanus à Visitatione B.M.V. ARP ${ }^{341}$, ex prior loci, nat. 1650, prof. 1669, obit. 31.01.1690 Oboriis.

Columbanus Krol RP ${ }^{342}$, nat. 1833, prof. 1857, obit. 29.11.1914 Oboriis.

Conradus à S. Chrysogomo ARP, Werner Josephus ${ }^{343}$, musicus excellens, praesidens oratorii SSmi Sanguinis Christi, in ante itinerans naufragium passus, sed invocans patrocinium B.M.V. in ecclesia nostra Markovicensi miraculis clarae, ex imo Vistulae evasit vivus et sanus. Id revera actum esse ipsemet iuramento comprobavit, nat. 20.07.1710, prof. 23.11.1731, obit. 14.11.1770 Posnaniae.

Constantinus à Jesu Maria ARP, Ancuta Michael $^{344}$, ex prior Kcynensis, Drohobicensis et Plonscensis, subprior loci, nat. 22.11.1700, prof. 17.06.1717, obit. 21.03.1760 Varsaviae.

Constantinus à S. Jacobo ARP, Klimkowski Jacobus ${ }^{345}$, ex definitor, ex prior Trutoviensis et actualis prior Kcynensis, nat. 02.08.1762, prof. 02.08.1778 Gedani, presb. 14.08.1785 Gedani, obit. sub manu medici 09.08.1811 Bidgostiae.

Constantinus à S. Laurentio ARP, Komierowski Casimirus ${ }^{346}, \mathrm{STL}$, emeritus, ex provincialis, bis ex definitor, prothonotarius apostolicus, praepositus cum dispensatione Romana Drvalensis, bis praeses capituli, multorum annorum prior Varsaviensis, ex secretarius provinciae, commissarius disignatus a Nuntio Apostolico ad Provinciam S. Georgii

${ }^{338}$ AKKr 174/614, s. 36; Kart. 27, s. 411; AKKr 175/547, s. 373; Zak. 66; Zak. 61, s. 185 i 186 : przekreślony zapis z datą zgonu 5 lipca 1762; AAG, ACon G II 4, s. 10v: członek konwentu w Kcyni w 1739. Święcenia prezbiteratu otrzymał 25 października 1739 w kaplicy Potockich w katedrze w Gnieźnie z rąk sufragana gnieźnieńskiego Krzysztofa Dobińskiego.

${ }^{339}$ AKKr 174/614, s. 14-15; AKKr 175/547, s. 481; Zak. 66; Zak. 61, s. 230.

${ }^{340}$ AKKr 175/547, s. 245; Zak. 66.

${ }^{341}$ AKKr 175/547, s. 61; Zak. 66; Zak. 61, s. 31.

${ }^{342}$ AKKr 175/547, s. 671.

${ }^{343}$ AKKr 174/614, s. 37: podana data zgonu 16 listopada 1770; Kart. 27, s. 411; AKKr 175/547, s. 641; Zak. 66; Zak. 61, s. 312: podana data zgonu 16 listopada 1770; ADP, A 16, s. 31 i 32: członek konwentu w Oborach w 1734. Święcenia diakonatu otrzymał 18 grudnia 1734 i prezbiteratu 21 grudnia 1734 w Chełmży z rąk sufragana chełmińskiego Macieja Aleksandra Sołtyka.

${ }^{344}$ AKKr 174/614, s. 35; Kart. 27, s. 409; AKKr 175/547, s. 173; Zak. 66; Zak. 61, s. 86: podana data zgonu 27 marca 1760.

${ }^{345}$ AKKr 174/614, s. 14-15; AKKr 175/547, s. 445; Zak. 66.

${ }^{346}$ AKKr 174/614, s. 4-5 i 39; Kart. 27, s. 413; AKKr 175/547, s. 719; Zak. 66; Kroniczka, s. 34, 36, 39-40, 42, 54-55, 128 i 191; Borkowska OSB, Leksykon, s. 149; Żychliński, Złota księga, Poznań 1888, T. 10, s. 190: błędnie informacja: po zniesieniu zaś zakonów proboszcz Drwalewski. Syn Andrzeja i Ewy Lubstowskiej. Jego siostra Franciszka, w zak. Agata (1715-1783) to klaryska bydgoska. Jego brat Ignacy (1720-?) był również karmelitą trzewiczkowym. Prowincjał w latach $1763-1765$. 
antiquae regularis observantiae FF Ordinis nostri, nat. 22.02.1724, prof. 12.08.1742 Posnaniae, presb. 19.03.1747 Varsaviae, obit. 23.12.1776 villa Trzylatkowo, sepultus Lipiae.

Constantinus à $\mathbf{S}$. Nicolao $\mathrm{ARP}^{347}$, praesidens loci, ubi fabricam ecclesiae notabiliter complevit, nat. 1690, prof. 1722, obit. 26.11.1740 Trutoviae.

Cornelius à S. Adamo RP, Zelnerowski Adamus ${ }^{348}$, ex concionator Polonorum, nat. 29.12.1740, prof. 22.09.1757 Gedani, presb. 13.04.1764 Bidgostiae, obit. 20.08.1778 Lipiae.

Cornelius à S. Antonio RP ${ }^{349}$, lector philosophiae, nat. 1698, prof. 1717, obit. 10.06.1732 Kcynae.

Cornelius à S. Euphemia $\mathrm{ARP}^{350}$, olim prior Gedanensis, residens oratorii Sanguinis Christi Posnaniae, nat. 1669, prof. 1689, obit. 12.04.1715 Posnaniae.

Cornelius à S. Jacobo Wasztel RP ${ }^{351}$, per Reverendissimum Generalem affiliatus nostae Provinciae, discessus a conventu Varsaviensi ad sublevandam aegram valetudinem, nat. 1803, presb. 1840, obit. 09.10.1861 Miedzierza.

Cornelius à S. Josepho RP, Kruza Josephus ${ }^{352}$, nat. 24.03.1767, prof. 18.10.1786 Gedani.

Cornelius à S. Luca RP ${ }^{353}$, nat. 1685, prof. 1703, obit. 21.09.1715 Posnaniae.

Cornelius à S. Michaele RP, Stoll Petrus ${ }^{354}$, nat. 07.06.1711, prof. 08.10.1736, obit. 06.07.1756 Drohobiciis.

Cornelius Sokołowski RP ${ }^{355}$, emeritus Ordinis Patrum Discalceatorum, nat. 1805, prof. 1825, obit. 10.04.1870 Oboriis.

Corsinus à S. Joanne RP, Lewandoski Joannes ${ }^{356}$, nat. 16.06.1766, prof. 24.10.1784 Posnaniae, presb. 18.09.1790 Varsaviae, obit. 09.02.1828 Trutoviae.

Corsinus à S. Josepho Lesnau RP ${ }^{357}$, ex subprior Oboriensis, Trutoviensis et Wąsosensis, ex concionator, nat. 1790, prof. 1821, presb. 1826, obit. 26.06.1848 Varsaviae.

${ }^{347}$ AKKr 175/547, s. 665; Zak. 66; Zak. 61, s. 138 i 323: podana data zgonu 18 maja 1740 i 27 listopada 1740.

${ }^{348}$ AKKr 174/614, s. 6-7 i 40; AKKr 175/547, s. 467; Zak. 66; Zak. 61, s. 224.

${ }^{349}$ AKKr 175/547, s. 323; Zak. 66; Zak. 61, s. 161; Kroniczka, s. 14 i 189: sekretarz konwentu Bożego Ciała w 1724. Drugi przełożony rezydencji przy kościele Najświętszej Krwi Pana Jezusa w Poznaniu. Podana informacja, że zmarł na tym stanowisku, wobec powyższego błędna.

${ }^{350}$ AKKr 175/547, s. 205; Zak. 66; Zak. 61, s. 102; Kroniczka, s. 6 i 188; ADP, A 41, s. 5v i 8v: członek konwentu w Oborach i w Bydgoszczy. Tonsurę i niższe święcenia, bierzmowanie oraz święcenia subdiakonatu otrzymał 31 marca 1691 w katedrze w Chełmży, diakonatu 14 kwietnia 1691 w kościele parafialnym w Chełmnie i prezbiteratu otrzymał 20 grudnia 1692 w katedrze w Chełmży z rąk sufragana chełmińskiego Tomasza Skotnickiego. Przeor w Gdańsku i drugi definitor prowincji w 1702 .

${ }^{351}$ AKKr 175/547, s. 569; Zak. 66.

${ }^{352}$ AKKr 174/614, s. 18-19.

${ }^{353}$ AKKr 175/547 s. 533; Zak. 66; Zak. 61, s. 259: podana data zgonu 24 września 1715.

${ }^{354}$ AKKr 174/614, s. 34; Kart. 27, s. 412; AKKr 175/547 s. 377; Zak. 66; Zak. 61, s. 187; ADP, A 16, s. 59 i 60: członek konwentu w Bydgoszczy w 1738. Tonsurę i niższe święcenia otrzymał 10 sierpnia 1738, święcenia subdiakonatu 12 sierpnia 1738, diakonatu 15 sierpnia 1738 i prezbiteratu 17 sierpnia 1738 w Chełmży. Szafarzem wszystkich święceń był sufragan chełmiński Maciej Aleksander Sołtyk.

${ }^{355}$ AKKr 175/547, s. 201.

${ }^{356}$ AKKr 174/614, s. 18-19; AKKr 175/547, s. 79; Zak. 66: podany zgon 15 marca 1828.

${ }^{357} \mathrm{AKKr}$ 175/547, s. 359: podana data zgonu 27 czerwca 1848; Zak. 66. 
Corsinus à S. Sebastiano RP, Luszczewicz Sebastianus ${ }^{358}$, ex concionator Polonorum, nat. 12.01.1736, prof. 19.02.1755 Posnaniae, presb. 29.09.1760 Posnaniae, obit. 18.09.1782 Bidgostiae.

Crispinianus à S. Stephano Fr, Kozlowski Stepanus ${ }^{359}$, nat. 03.09.1733, prof. 22.02.1759 Posnaniae, obit. 06.11.1787 Plonscii.

Crispinianus à $\mathrm{S}$. Thoma $\rightarrow$ Crispinianus à $\mathrm{S}$. Stephano

Crispinus à S. Antonio ARP, Bylang Antonius ${ }^{360}$, prior loci, nat. 26.03.1769, prof. 15.08.1785 Gedani, presb. 1792, obit. 13.09.1817 Lipiae.

Crispinus à S. Gregorio $\mathrm{Fr}^{361}$, nat. 1671, prof. 1691, obit. 08.07.1709 Posnaniae.

Crispinus à S. Luca $\mathrm{Fr}^{362}$, terminarius, nat. 1694, prof. 1721, obit. 01.01.1740 Posnaniae.

Crispinus à S. Michaele ARP, Stucki Michael ${ }^{363}$, annis interpolatim duodecim prior Gedanensis, vir charitate vere paterna erga fratres irrestrictim omnes praeditissimus, electus in definitorem 1-mum, sub tempus Venerabilis Capituli obiit, nat. 09.12.1732, prof. 17.03.1751 Gedani, presb. 02.02.1756 Posnaniae, obit. 09.05.1784 Oboriis.

Cyprianus à S. Casimiro ARP, Langhanig Casimirus ${ }^{364}$, ex magister novitiorum per multos annos existens, ex subprior variis in conventibus, actualis prior loci, diem clausit extremum vitae suae, nat. 06.03.1698, prof. 26.09.1717, obit. 28.04.1749 Lipiae.

Cyprianus à S. Christiano $\mathrm{ARP}^{365}$, ex prior Bidgostiensis, nat. 1661, prof. 1680, obit. 24.10.1705 Oboriis.

Cyprianus à S. Gerardo ARP, Gramzyc Mathias ${ }^{366}$, concionator Polonorum, ex prior Bidgostiensis, Oboriensis et Gedanensis, demum praesidens in nova fundatione Jasienecensi, nat. 16.02.1696, prof. 26.09.1716, obit. 25.01.1747 Zielon..

${ }^{358}$ AKKr 174/614, s. 6-7 i 42; AKKr 175/547 s. 527; Zak. 66; Zak. 61, s. 251: podana data zgonu 16 września 1782; T. Nowicki, Kościót, duchowieństwo i parafianie fordońscy wedtug wizytacji kanonicznej z 25 października 1781 r., [w:] „Kronika Bydgoska”, 19: 1998, s. 292; A. Mańkowski, Liber mortuorum Monasterii Coronoviensis O. Cist., [w:] „Fontes Towarzystwa Naukowego w Toruniu", 25: 1931, s. 81: będąc członkiem konwentu bydgoskiego w 1781 był kapelanem w Strzelcach u podstolego kowalskiego Andrzeja Moszczeńskiego. Konfrater cystersów koronowskich.

${ }^{359} \mathrm{AKKr} 174 / 614$, s. 24-25; AKKr 175/547, s. 625: podane imiona zakonne Crispinianus à S. Thoma; Zak. 66: podane imiona zakonne Cyprianus à S. Stephano; Zak. 61, s. 302.

${ }^{360} \mathrm{AKKr}$ 174/614, s. 18-19; AKKr 175/547, s. 517; Zak. 66: podana data zgonu 2 października 1817.

${ }^{361}$ AKKr 175/547 s. 381; Zak. 66; Zak. 61, s. 189.

${ }^{362}$ AKKr 175/547, s. 1; Zak. 61, s. 1.

${ }^{363}$ AKKr 174/614, s. 6-7; AKKr 175/547 s. 259; Zak. 66; Zak. 61, s. 129; Zakonnicy, s. 336.

${ }^{364}$ AKKr 174/614, s. 32; Kart. 27, s. 409; AKKr 175/547 s. 237; Zak. 66; Zak. 61, s. 106: podana data zgonu 16 kwietnia 1749; Reszel, Bd.16, H.46, Braunsberg 1906, s. 165 (wpis nr 2114): syn Jerzego i Anny. Urodził się 6 marca 1698 w Bisztynku na Warmii i tego samego dnia został ochrzczony w tamtejszym kościele parafialnym. Od 1712 kształcił się w gimnazjum jezuickim w Reszlu.

${ }^{365}$ AKKr $175 / 547$ s. 599; Zak. 66; Zak. 61, s. 289.

${ }^{366}$ AKKr 174/614, s. 31; Kart. 27, s. 409; AKKr 175/547 s. 49; Zak. 66; Zak. 61, s. 15: podana data zgonu 15 stycznia 1747 Jasieniec. 
Cyprianus à S. Gerardo ARP, Satorski Lucas ${ }^{367}$, STL, bis ex provincialis, ex definitor, ex secretarius provinciae, ex prior Oboriensis et Trutoviensis, nat. 15.10.1729, prof. 01.10.1748 Posnaniae, presb. 22.04.1753 Varsaviae, obit. 20.03.1793 Oboriis.

Cyprianus à S. Joanne Evangelista ARP ${ }^{368}$, ex prior loci, obit. 20.01.1677 Gedani.

Cyprianus à S. Joanne $\mathrm{Fr}^{369}$, clericus, studens theologiae, nat. 1778, prof. 1796, obit. 04.05.1801 Gedani.

Cyprianus à S. Mathia $\mathrm{ARP}^{370}$, ex prior Gedanensis, nat. 1643, prof. 1662, obit. 06.04.1678 Bidgostiae.

Cyprianus à S. Stephano $\rightarrow$ Crispinianus à $\mathrm{S}$. Stephano

Cyprianus à S. Vincentio Dąbrowski Fr ${ }^{371}$, clericus, studens rhetorices, nat. 1800, prof. 1822, obit. 10.10.1828 Plonscii.

Cyriacus à S. Cajetano Fr, Lauterbach Joannes ${ }^{372}$, nat. 12.01.1716, prof. 10.08.1751 Posnaniae, obit. 18.10.1774 Plonscii.

Cyriacus à S. Jacobo RP, Kęsicki Jacobus ${ }^{373}$, subprior loci, nat. 18.05.1749, prof. 24.08.1769 Gedani, obit. 04.03.1814 Plonscii.

Cyriacus à $S$. Mathaeo $\rightarrow$ Cyriacus à $S$. Cajetano

Cyriacus à S. Simone RP, Cizowski Simon ${ }^{374}$, procurator, nat. 26.10.1702, prof. 10.08.1722, obit. 29.01.1747 Plonscii.

Cyriacus Biernacki RP ${ }^{375}$, nat. 1793, obit. 31.07.1876 Oboriis.

Cyrillus à Conversione S. Pauli RP ${ }^{376}$, nat. 1647, prof. 1666, obit. 01.09.1714 Gedani.

Cyrillus à Nativitate B.M.V. RP ${ }^{377}$, nat. 1665, prof. 1683, obit. 27.05.1693 Posnaniae.

Cyrillus à Purtificat B.M.V. RP ${ }^{378}$, oeconomus, nat. 1697, prof. 1715, presb. 1721, obit. 21.01.1743 Lipiae.

${ }^{367}$ AKKr 174/614, s. 4-5: podana data zgonu 10 marca 1793; AKKr 175/547 s. 159; Zak. 66; Zak. 61, s. 79.

${ }^{368}$ AKKr 175/547, s. 39; Zak. 66; Zak. 61, s. 20.

${ }^{369}$ Zak. 66; Zak. 61, s. 124; Zakonnicy, s. 336: podana data zgonu 10 września 1801.

${ }^{370}$ AKKr 175/547, s. 193; Zak. 66; Zak. 61, s. 96.

${ }^{371}$ AKKr 175/547, s. 571; Zak. 66: podana data zgonu 29 sierpnia 1828.

${ }^{372} \mathrm{AKKr} 174 / 614$, s. 22-23 i 39: podane imiona zakonne Cyriacus à S. Mathaeo; AKKr 175/547, s. 587 ; Zak. 66 ; Zak. 61, s. 283.

${ }^{373}$ AKKr 174/614, s. 10-11; AKKr 175/547, s. 127 i 283: drugi zapis zgonu 21 maja 1816; Zak. 66: data zgonu 23 marca 1816; ADP, C 54a, s. 84 i 85: członek konwentu w Bydgoszczy w 1772. Tonsurę i niższe święcenia otrzymał 2 sierpnia 1772, święcenia subdiakonatu 10 sierpnia 1772, diakonatu 16 sierpnia 1772 i prezbiteratu 23 sierpnia 1772 w Chełmży. Szafarzem wszystkich święceń był sufragan chełmiński Franciszek Fabian Pląskowski.

${ }^{374}$ AKKr 174/614, s. 31: podana data zgonu 18 stycznia 1747; Kart. 27, s. 409; AKKr 175/547, s. 57; Zak. 66; Zak. 61, s. 29; AAG, ACap B 79, s. 53: członek konwentu w Poznaniu w 1728. Święcenia subdiakonatu otrzymał 11 stycznia 1728 w kaplicy seminarium w Gnieźnie z rąk sufragana gnieźnieńskiego Franciszka Kraszkowskiego.

${ }^{375}$ AKKr 175/547, s. 427.

${ }^{376}$ AKKr 175/547, s. 493; Zak. 66; Zak. 61, s. 123 i 233: podane daty zgonu 3 maja i 29 sierpnia 1714; Kroniczka, s. 5, 6 i 188: klucznik w klasztorze Bożego Ciała w Poznaniu w 1686, syndyk w 1687, podprzeor w 1691 oraz przeor i pierwszy definitor prowincji w 1702.

${ }^{377}$ AKKr 175/547, s. 295; Zak. 66; Zak. 61, s. 147.

${ }^{378}$ AKKr 174/614, s. 31: podana data zgonu 21 czerwca 1743; AKKr 175/547, s. 41; Zak. 66; Zak. 61, s. 21. 
Cyrillus à S. Basilio ARP, Sarnowski Joannes ${ }^{379}$, ex concionator Polonorum, ex prior Markovicensis, subprior loci, nat. 07.12.1721, prof. 22.02.1744 Posnaniae, presb. 16.11.1748 Posnaniae, obit. 21.01.1781 Kcynae.

Cyrillus à S. Casimiro Fr, Szyskowski Casimirus ${ }^{380}$, oeconomus in Stara Łąka, nat. 17.08.1748, prof. 24.08.1779 Gedani, obit. 20.10.1790 Posnaniae.

Cyrillus à S. Gregorio $\mathrm{Fr}^{381}$, nat. 1654, prof. 1679, obit. 11.03.1706 Gedani.

Cyrillus à S. Josepho ARP, Golonka Josephus ${ }^{382}$, ex secretarius et ex definitor provinciae, rubricista, prior Posnaniensis, bis primitians, vir virtutibus plenus et religiosus devotus. Cujus anima per misericordiam Dei et intercessionem B.M.V., Omniumque Sanctorum requiescat in pace, obiit in capella Sanguinis Christi, nat. 16.12.1766, prof. 05.02.1783 Gedani, obit. 27.11.1843 Posnaniae.

Cyrillus à S. Laurentio $\mathrm{Fr}^{383}$, clericus novitius, nat. 1690, obit. 12.07.1709 Posnaniae.

Damascenus à S. Bartholomaeo RP ${ }^{384}$, subprior loci, nat. 1669, prof. 1697, obit. 03.02.1720 Kcynae.

Damascenus à S. Stanislao RP, Gapinski Stanislaus ${ }^{385}$, bis primitians, nat. 08.05.1708, prof. 09.11.1733 Posnaniae, presb. 20.07.1738 Kcynae, obit. 12.10.1794 Trutoviae.

Damasus à S. Adamo $\mathrm{Fr}^{386}$, architecturae peritus, nat. 1718, prof. 1743, obit. 14.01.1761 Markovicae.

Damasus à S. Francisco RP ${ }^{387}$, concionator Polonorum et festivalis, nat. 1742, prof. 1763, presb. 1766, obit. 12.11.1772 Kcynae.

Damasus à S. Joanne Cruce RP ${ }^{388}$, nat. 1669, prof. 1690, obit. 09.05.1730 Kcynae.

Damasus à S. Margaritha $\mathrm{Fr}^{389}$, nat. 1678, prof. 1700, obit. 27.04.1720 Kcynae.

${ }^{379}$ AKKr 174/614, s. 4-5 i 41: na stronie 4-5 podana data zgonu 22 stycznia 1781; Kart. 27, s. 414; AKKr 175/547, s. 41; Zak. 66.

${ }^{380}$ AKKr 174/614, s. 26-27; AKKr 175/547, s. 621: podana data zgonu 4 listopada 1790; Zak. 66: podana data zgonu 26 października 1790.

${ }^{381}$ AKKr 175/547, s. 141; Zak. 66; Zak. 61, s. 70.

${ }^{382}$ AKKr 174/614, s. 16-17; AKKr 175/547, s. 667; Zak. 66.

${ }^{383}$ AKKr 175/547, s. 389; Zak. 66; Zak. 61, s. 193 i 200: podana druga data zgonu 19 lipca 1709.

${ }^{384}$ AKKr 175/547, s. 67; Zak. 66; Zak. 61, s. 34.

${ }^{385}$ AKKr 174/614, s. 2-3; Kart. 27, s. 412; AKKr 175/547, s. 575; Zak. 66; Zak. 61, s. 277.

${ }^{386}$ AKKr 174/614, s. 35; AKKr 175/547, s. 27; Zak. 66; Zak. 61, s. 14.

${ }^{387}$ AKKr 174/614, s. 38: podana data zgonu 10 maja 1771; AKKr 175/547, s. 637; Zak. 66; Zak. 61, s. 308 i 130: podana data zgonu 10 maja 1771; ADP, C 54a, s. 63 i 64: członek konwentu w Bydgoszczy w 1765. Święcenia subdiakonatu otrzymał 30 listopada 1765, diakonatu 15 grudnia 1765 i prezbiteratu 21 grudnia 1765 w Chełmży z rąk sufragana chełmińskiego Franciszka Fabiana Pląskowskiego; Kroniczka, s. 93, 94, 161 i 196: przebywał w rezydencji przy kościele Najświętszej Krwi Pana Jezusa w Poznaniu w 1767. W 1769 student teologii.

${ }^{388}$ AKKr 175/547, s. 259; Zak. 66; Zak. 61, s. 155: podana data zgonu 4 czerwca 1730; ADP, A 41, s. 21, 22v i 23: przy diakonacie podane imiona Damazy od św. Krzyża. Członek konwentu w Oborach w latach 1698-1700. Święcenia subdiakonatu otrzymał 24 maja 1698, diakonatu 14 marca 1699 i prezbiteratu 5 czerwca 1700 w katedrze w Chełmży z rąk sufragana chełmińskiego Tomasza Skotnickiego.

${ }^{389}$ AKKr 175/547, s. 235; Zak. 66; Zak. 61, s. 117. 
Damasus à S. Michaele RP ${ }^{390}$, nat. 1668, prof. 1689, obit. 28.06.1696 Torunii, sub manu medici.

Damasus à S. Thoma RP, Jastrzębski Thomas ${ }^{391}$, ex concionator Polonorum, nat. 31.12.1747, prof. 17.07.1772 Posnaniae, presb. 25.07.1773 Gedani, obit. 21.01.1804 Oboriis.

Damianus à S. Casimiro Fr, Kulaszewski Casimirus ${ }^{392}$, dispensator, nat. 1758, prof. 22.02.1781 Gedani, obit. 29.11.1794 Varsaviae.

Damianus à S. Jacobo ARP, Cychon Jacobus ${ }^{393}$, ex prior Drohobicensis, nat. 08.07.1725, prof. 21.09.1745 Gedani, presb. 22.04.1753 Varsaviae, obit. 11.08.1793 Oboriis.

Damianus à S. Michaele RP ${ }^{394}$, nat. 1670, prof. 1690, obit. 15.07.1696 Oboriis.

Daniel à S. Francisco RP, Böhm Franciscus ${ }^{395}$, bis primitians, nat. 21.02.1742, prof. 11.09.1764 Gedani, presb. 15.08.1765 Gedani, obit 24.06.1817 Posnaniae.

Daniel à S. Joanne Fr, Vober Joannes ${ }^{396}$, nat. 02.02.1760, prof. 02.09.1782 Gedani.

Daniel à S. Joanne RP ${ }^{397}$, nat. 1657, prof. 1675, obit. 21.10.1706 Varsaviae.

Daniel à S. Josepho RP, Gerigk Josephus ${ }^{398}$, nat. 14.03.1716, prof. 05.01.1740, presb. 1747, obit. 30.08.1762 Plonscii.

Daniel à S. Nazario RP ${ }^{399}$, nat. 1662, prof. 1685, obit. 22.11.1708 Posnaniae.

Daniel à S. Susanna RP ${ }^{400}$, nat. 1683, prof. 1704, obit. 05.08.1716 Varsaviae.

Daniel à Virgine Maria $\mathrm{RP}^{401}$, vir scientificus, orator, concionator egregius, ex professor rethorices, actualis lector philosophiae, nat. 1702, prof. 1726, obit. 05.04.1737 Bidgostiae.

David à S. Gasparo RP, Hoppa Gaspar ${ }^{402}$, exorcista, nat. 28.11.1745, prof. 09.06.1766 Gedani, presb. 14.10.1770 Kcynae, obit. 20.08.1791 Markovicae.

David à S. Justina Fr, Kainski Jacobus ${ }^{403}$, sartor et terminarius, nat. 25.07.1710, prof. 01.10.1733, obit. 30.10.1744 Fridland.

${ }^{390}$ AKKr 175/547, s. 361; Zak. 66.

${ }^{391}$ AKKr 174/614, s. 12-13; AKKr 175/547, s. 41; Zak. 66.

${ }^{392}$ AKKr 174/614, s. 26-27; Zak. 66; Zak. 61, s. 323: podana data zgonu 27 listopada, brak ro$\mathrm{ku}$.

${ }^{393}$ AKKr 174/614, s. 4-5; AKKr 175/547, s. 449; Zak. 66.

${ }^{394}$ AKKr 175/547, s. 395; Zak. 66; Zak. 61, s. 196: podane miejsce zgonu Toruń; ADP, A 41, s. 10v: święcenia diakonatu otrzymał 19 grudnia 1693 w katedrze w Chełmży z rąk sufragana chełmińskiego Tomasza Skotnickiego.

${ }^{395}$ AKKr 174/614, s. 8-9; AKKr 175/547, s. 353; Zak. 66: podana data zgonu 1 lipca 1817.

${ }^{396}$ AKKr 174/614, s. 26-27.

${ }^{397}$ AKKr 175/547, s. 593; Zak. 66; Zak. 61, s. 286: podana data zgonu 21 października 1716.

${ }^{398} \mathrm{AKKr}$ 174/614, s. 36: podana data zgonu 31 sierpnia 1762; Kart. 27, s. 413; AKKr 175/547, s. 489; Zak. 66; Zak. 61, s. 235: podana data zgonu 31 sierpnia 1762.

${ }^{399}$ AKKr 175/547, s. 657; Zak. 66; Zak. 61, s. 319: podana data zgonu 23 listopada 1708.

${ }^{400}$ AKKr 175/547, s. 437; Zak. 66; Zak. 61, s. 217.

${ }^{401}$ AKKr 175/547, s. 191; Zak. 66; Zak. 61, s. 95; AAG, ACap B 79, s. 53: członek konwentu w Poznaniu w 1728. Święcenia diakonatu otrzymał 11 stycznia 1728 w kaplicy seminarium w Gnieźnie z rąk sufragana gnieźnieńskiego Franciszka Kraszkowskiego.

${ }^{402}$ AKKr 174/614, s. 10-11: podana data zgonu 12 sierpnia 1791; AKKr 175/547, s. 467; Zak. 66; Zak. 61, s. 224.

${ }^{403}$ AKKr 174/614, s. 31: Debrzno w archidiakonacie kamieńskim archidiecezji gnieźnieńskiej; Kart. 27, s. 415; AKKr 175/547, s. 611; Zak. 66: podane miejsce zgonu Markowice; Zak. 61, s. 294: podana data zgonu 29 października 1744. 
Dionysius à S. Antonio ARP, Kiner Antonius ${ }^{404}$, emeritus, bis primitians, concionator Germanorum, secretarius provinciae, ex prior Lipiensis et Gedanensis, seniculus, magister novitiorum, nat. 19.01.1668, prof. 10.10.1688, obit. 09.03.1748 Gedani.

Dionysius à S. Floriano RP ${ }^{405}$, nat. 1653, prof. 1673, obit.10.05.1690 Gedani.

Dionysius à S. Ignatio RP, Sarnowski Ignatius ${ }^{406}$, concionator Polonorum, nat.27.07.1726, prof. 09.10.1749 Posnaniae, presb. 09.02.1755 Kcynae, obit. 27.09.1797 Markovicae.

Dionysius à S. Joanne RP ${ }^{407}$, nat. 1647, prof. 1663, obit. 04.01.1694 Gedani.

Dionysius à S. Michaele Fr, Parzau Michael ${ }^{408}$, braxator, terminarius, bene meritus, nat. 30.08.1731, prof. 04.02.1767 Posnaniae, obit. 10.11.1774 Plonscii.

Dionysius à S. Michaele $\mathrm{Fr}^{409}$, terminarius, bene meritus, nat. 1679, prof. 1713, obit. 15.07.1744 Markovicae.

Dionysius à S. Nicolao Fr, Dobrzynski Nicolaus ${ }^{410}$, terminarius, quaestiarius, nat. 1766, prof. 21.12.1789 Gedani, obit. 01.01.1818 Varsaviae.

Dionysius à S. Paulo Fr, Szpecht Paulus ${ }^{411}$, nat. 11.04.1756, prof. 20.10.1780, ejectus in cerrigibilis.

Dionysius à S. Rustico RP ${ }^{412}$, nat. 1635, prof. 1656, obit. 09.06.1685 Bidgostiae.

Dionysius Grzecznowski $\mathrm{Fr}^{413}$, conversus, hortulanus eximius, nat. 1910, prof. 1932 , obit. 16.07.1934 Cracoviae.

Dionysius Mierzwicki ARP ${ }^{414}$, ex prior Oboriensis, nat. 1841, obit. 22.02.1920 Oboriis.

Dionysius $\mathrm{RP}^{415}$, bis primitians, obit. 29.03.1683 Gedani.

Dismas à S. Adalberto ARP, Szymanowicz Adalbertus ${ }^{416}$, actualis prior loci, nat. 24.04.1755, prof. 06.11.1774 Posnaniae, presb. 26.12.1781 Posnaniae, obit. 16.04.1801 Trutoviae.

${ }^{404}$ AKKr 174/614, s. 31; Kart. 27, s. 407; AKKr 175/547, s. 137; Zak. 66; Zak. 61, s. 67 i 94: podana data zgonu 8 marca i 4 kwietnia 1748; Zakonnicy, s. 334; ADP, A 41, s. 5: święcenia diakonatu otrzymał 20 maja 1690 w katedrze w Chełmży z rąk sufragana chełmińskiego Tomasza Skotnickiego; Kroniczka, s. 14 i 189: pierwszy przełożony rezydencji przy kościele Najświętszej Krwi Pana Jezusa w Poznaniu w 1704. Później asystent prowincjała. Wielokrotny przeor klasztorów karmelitów trzewiczkowych. Definitor prowincji. Przebywał w klasztorach w Bydgoszczy i Gdańsku.

${ }^{405}$ AKKr 175/547, s. 261; Zak. 66; Zak. 61, s. 130.

${ }^{406}$ AKKr 174/614, s. 6-7; Zak. 66; Zak. 61, s. 246: podana data zgonu 11 września 1797.

${ }^{407}$ AKKr 175/547 s. 7 i 177: podana druga data zgonu 29 marca 1683; Zak. 66: podana druga data zgonu 29 marca 1683; Zak. 61, s. 4.

${ }^{408}$ AKKr 174/614, s. 24-25 i 39: podana data zgonu 29 kwietnia 1774; AKKr 175/547, s. 633; Zak. 66; Zak. 61, s. 306, 118 i 196: podane również daty zgonu 28 kwietnia i 15 lipca 1774.

${ }^{409}$ AKKr 174/614, s. 31; AKKr 175/547, s. 395; Zak. 66.

${ }^{410}$ AKKr 174/614, s. 28; Zak. 66: podana druga data 1 kwietnia 1818; AKKr 175/547, s. 183: zmarł 1 kwietnia 1818 w Warszawie.

${ }^{411}$ AKKr 174/614, s. 26-27.

${ }^{412}$ AKKr 175/547, s. 321; Zak. 66; Zak. 61, s. 160.

${ }^{413}$ AKKr 175/547, s. 397.

${ }^{414}$ AKKr 175/547, s. 105.

${ }^{415}$ Zak. 61, s. 88.

${ }^{416}$ AKKr 174/614, s. 14-15; Zak. 66; Zak. 61, s. 182: podana data zgonu 1 lipca 1801. 
Dominicus à S. Christophoro $\mathrm{RP}^{417}$, nat. 1680, prof. 1700, obit. 18.08.1710 Bidgostiae.

Dominicus à S. Joanne ARP, Kegler Joannes ${ }^{418}$, STL, ex provincialis, concionator Germanorum, nat. 06.10.1740, prof. 05.08.1767 Posnaniae, presb. 02.07.1770 Varsaviae, obit. 23.01.1826 Gedani.

Donatus à S. Antonio RP, Klinger Antonius ${ }^{419}, 7$ annis concionator Germanorum Varsaviensis, nemini secundus, nat. 18.10.1722, prof. 04.04.1741, obit. 28.05.1767 Varsaviae.

Donatus à S. Joanne RP, Rumczynski Joannes ${ }^{420}$, ex concionator Germanorum, musicus, nat. 15.10.1747, prof. 27.08.1768 Gedani, presb. 08.12.1770 Gedani, obit. 30.06.1789 Markovicae.

Donatus à S. Michaele Michalski ARP ${ }^{421}$, ex definitor provinciae, concionator Plonscensis, ultimo vicarius parochialis in villa Ostrołęka dioecesis Plocensis, nat. 1817, presb. 1854, obit. 28.06.1867 Ostrołęka.

Donatus Gronau ARP 422 , ex prior Gedanensis, ex definitor, provincialis, nat. 1773, prof. 1793, presb. 1799, obit. 01.04.1831 obit et sepultus in villa Bogate.

Eadmundus à S. Andrea à Annis RP, Kuhn Andreas ${ }^{423}$, ex concionator Germanorum in Conventu Gedanensi, nat. 01.11.1699, prof. 30.11.1721, obit. 08.01.1762 Oboriis.

Eadmundus à S. Jacobo RP, Gerszewski Jacobus ${ }^{424}$, concionator Polonorum in nova fundatione Jasienecensi, nat. 04.08.1697, prof. 06.12.1720, obit. 20.10.1750 in Zielonka.

Eadmundus à S. Michaele ARP, Froncki Michael ${ }^{425}$, prior loci, nat. 12.10.1738, prof. 06.11.1764 Posnaniae, presb. 29.12.1765 Bidgostiae, obit. 07.05.1810 Kcynae.

${ }^{417}$ AKKr 175/547, s. 463; Zak. 66.

${ }^{418}$ AKKr 174/614, s. 10-11; Zak. 66; AKKr 175/547, s. 45 i 97: drugi zapis zgonu 18 lutego 1826; Informacje uzyskane od Pana Sławomira Kościelaka: Jan urodził się w 1740 w miejscowości Ehrenberg w Czechach. Do zakonu karmelitów wstąpił 7 sierpniu 1766. Profesję zakonną złożył w 1767.

${ }^{419}$ AKKr 174/614, s. 37; Kart. 27, s. 413; AKKr 175/547, s. 297; Zak. 66; Zak. 61, s. 148; Kroniczka, s. 24 i 190: zakrystianin w rezydencji przy kościele Najświętszej Krwi Pana Jezusa w Poznaniu między 1751, a 1757.

${ }^{420}$ AKKr 174/614, s. 10-11; AKKr 175/547, s. 365; Zak. 66; Zak. 61, s. 181.

${ }^{421}$ AKKr 175/547, s. 361.

${ }^{422}$ AKKr 175/547, s. 183; Zak. 66; Elenchus Cleri Dioecesis Culmensis 1825, s. 23; AA Gdańsk Oliwa, Parafia Puck, sygn. W 1223, chrzty 1773-1779, s. 17: Jan Piotr urodził się 19 stycznia 1775 w Pucku w rodzinie Filipa i Reginy Mazurckin. Został ochrzczony 25 stycznia w kościele parafialnym w Pucku przez Ojca Roberta Caspersohna, chrzestnymi byli Jan Busch i Luisa Wierczinska zd. Fichtin. Do zakonu karmelitów wstąpił 26 kwietnia 1792. Profesję zakonną złożył w 1793; ADP, C 54a, s. 179: członek konwentu w Gdańsku w 1799. Święcenia prezbiteratu otrzymał 15 grudnia 1799 w Chełmży z rąk sufragana chełmińskiego Iwona Onufrego Rogowskiego; Zawadzki, s. 325: w 1804 był duszpasterzem w Lichnowach w części pomezańskiej diecezji chełmińskiej. Przeor w Gdańsku w latach 1817-1826.

${ }^{423}$ AKKr 174/614, s. 35; Kart. 27, s. 409; AKKr 175/547, s. 9; Zak. 66; Zak. 61, s. 5 i 8: dnia 5 stycznia 1762 zapis przekreślony.

${ }^{424}$ AKKr 174/614, s. 32; Kart. 27, s. 409; AKKr 175/547, s. 595: podane miejsce zgonu Lipia; Zak. 66: podane miejsce zgonu Jasieniec w dekanacie Grójec; Zak. 61, s. 285.

${ }^{425}$ AKKr 174/614, s. 8-9; AKKr 175/547, s. 273: podana data zgonu 16 maja 1810; Zak. 66; ADP, C 54a, s. 63 i 64: członek konwentu w Bydgoszczy w 1765. Święcenia subdiakonatu otrzymał 
Eduardus à S. Francisco $\mathrm{ARP}^{426}$, ex prior Posnaniensis, ex lector theologiae et philosophiae, nat. 1683, prof. 1707, obit. 10.07.1731 Bidgostiae.

Eduardus à S. Mathaeo RP, Pączkowski Mathias ${ }^{427}$, nat. 20.09.1711, prof. 13.10.1732, presb. 1739, obit. 23.09.1755 Markovicae.

Eduardus à S. Petro (Thoma) RP, Grabowski Petrus ${ }^{428}$, syndicus provinciae, nat. 21.12.1749, prof. 04.06.1773 Gedani, presb. 16.07.1779 Klodaviae, obit. 17.07.1822 in residentia Sanguinis Christi, sepultus Posnaniae.

Eduardus à SS. Crispino \& Crispiniano RP, Gurski Bertholdus ${ }^{429}$, nat. 23.08.1711, prof. 04.11.1732, obit. 04.04.1767 Bidgostiae.

Elias à Monte Carmeli RP, Mataski Joannes ${ }^{430}$, STL, statura quidem pusillus, at organarius conspicuus et compositor (ad mentem Ecclesiastici); in peritia sua requirens modos musicos, ac narrans carmina Scripturarum, nat. 04.11.1690, prof. 20.07.1713, obit. 23.10.1752 Posnaniae.

Elias à S. Francisco ARP, Jedlinski Franciscus ${ }^{431}$, STL, jubilatus, tertio ex provincialis, ex prior loci, edidit binos libros theologiae moralis, item "Scrutinium Juris" in 5 tomos divisum, nat. 01.08.1672, prof. 30.08.1696, obit. 16.04.1748 Varsaviae.

Elias à S. Gregorio $\mathrm{Fr}^{432}$, nat. 1668, prof. 1689, obit. 09.01.1694 Oboriis.

Elias à S. Gregorio RP ${ }^{433}$, nat. 1669, prof. 1688, obit. 08.03.1707 Oboriis.

Elias à S. Jacobo Fr, Balicki Jacobus ${ }^{434}$, terminarius, nat. 23.07.1720, prof. 10.09.1756 Posnaniae, obit. 30.03.1777 Posnaniae.

Elias à S. Joanne RP, Morawski Joannes ${ }^{435}$, nat. 10.12.1766, prof. 02.06.1783 Gedani.

Elias à S. Josepho Skierkowski $\mathrm{Fr}^{436}$, diaconus, tempore aliquo professor scholae civitatis Klodaviensis, nat. 1771 , prof. 1806, obit. 08.12.1828 Klodaviae.

30 listopada 1765, diakonatu 15 grudnia 1765 i prezbiteratu 21 grudnia 1765 w Chełmży z rąk sufragana chełmińskiego Franciszka Fabiana Pląskowskiego.

${ }^{426} \mathrm{AKKr}$ 175/547, s. 385; Zak. 66; Zak. 61, s. 161 i 191: podana druga data zgonu 10 czerwca 1731.

${ }^{427}$ AKKr 174/614, s. 33: podana data zgonu 27 września 1755; Kart. 27, s. 411; AKKr 175/547, s. 537; Zak. 66; Zak 61, s. 262: podana data zgonu 27 września 1755.

${ }^{428}$ AKKr 174/614, s. 12-13; AKKr 175/547, s. 399; Zak. 66.

${ }^{429}$ AKKr 174/614, s. 37; Kart. 27, s. 411; AKKr 175/547, s. 189; Zak. 66; Zak. 61, s. 94.

${ }^{430}$ AKKr 174/614, s. 33: podana data zgonu 16 października 1752; Kart. 27, s. 408; AKKr 175/547, s. 597; Zak. 66; Zak. 61, s. 287: podana data zgonu 22 października 1752.

${ }^{431}$ AKKr 174/614, s. 32; Kart. 27, s. 407; AKKr 175/547, s. 213; Zak. 66; Zak. 61, s. 106; Biogram: SPTK, T.2, s. 86, Murawiec W. OFM, Idliński Eliasz od św. Franciszka (1658-1748), karmelita trzewiczkowy, moralista i kanonista.

${ }^{432}$ AKKr 175/547, s. 17; Zak. 66; Zak. 61, s. 9: podane miejsce zgonu Chełmno i określony jako ojciec.

${ }^{433}$ AKKr 175/547, s. 135; Zak. 66; Zak. 61, s. 67: podana data zgonu 8 marca 1708; ADP, A 41, s. 8 i 10v: członek konwentu w Bydgoszczy w latach 1692-1693. Tonsurę i niższe święcenia otrzymał 20 grudnia 1692, święcenia diakonatu 19 grudnia 1693 w katedrze w Chełmży z rąk sufragana chełmińskiego Tomasza Skotnickiego.

${ }^{434}$ AKKr 174/614, s. 22-23 i 40; AKKr 175/547, s. 179; Zak. 66: podane data zgonu 29 marca 1777 Grabowo; Zak. 61, s. 89.

${ }^{435}$ AKKr 174/614, s. 16-17.

${ }^{436}$ AKKr 175/547, s. 705: podana data zgonu 16 grudnia 1828; Zak. 66; AAG, ACon G II 3, s. 1: członek konwentu w Kłodawie w 1809. Tonsurę i niższe święcenia otrzymał 16 lipca 1809 w ko- 
Elias à S. Mathaeo ARP, Nogowski Mathaeus ${ }^{437}$, ex prior Markovicensis, bis primitians, nat. 17.09.1716, prof. 01.09.1733 Posnaniae, presb. 06.08.1742 Bidgostiae, obit. 18.06.1794 Plonscii.

Elias à S. Petrus Fr ${ }^{438}$, nat. 1646, prof. 1665, obit. 20.04.1674 Posnaniae.

Elias ab Immaculata Conceptione B.M.V. $\mathrm{Fr}^{439}$, nat. 1648, prof. 1683, obit. 29.12.1718 Drohobiciis.

Eliseus à Matre Dolorosa RP $\mathrm{P}^{440}$, nat. 1658, prof. 1677, obit. 01.02.1684 Gedani.

Eliseus à Monte Carmeli RP ${ }^{441}$, subprior Posnaniensis, subprior loci, nat. 1667, prof. 1687, obit. 21.01.1710 Bidgostiae.

Eliseus à S. Alberto (Adalbertus) Fr, Olszak (Oliszewski) Adalbertus ${ }^{442}$, nat. 13.01.1715, prof. 01.07.1740 Posnaniae, obit. 16.07.1791 Klodaviae.

Eliseus à S. Antonio RP ${ }^{443}$, nat. 1661, prof. 1695, obit. 12.08.1710 Bidgostiae. dani.

Eliseus à S. Apollinare ARP ${ }^{444}$, ex prior, nat. 1634, prof. 1663, obit. 06.06.1684 Ge-

Eliseus à S. Elia Fr ${ }^{445}$, nat. 1656, prof. 1676, obit. 30.05.1690 Posnaniae.

Eliseus à S. Gabriele ARP, Ossowski Gabriel ${ }^{446}$, ex prior Plonscensis, concionator Polonorum, subprior loci, nat. 09.03.1716, prof. 01.09.1733 Posnaniae, presb. 21.01.1742 Plonscii, obit. 29.03.1776 Oboriis.

Eliseus à S. Joanne Baptista $\mathrm{ARP}^{447}$, Gallo-Belgicus misionarius in Poloniam pro refor-matione ad Provinciam, reformator provinciae, ex vicarius provinciae, magister novitiorum Posnaniensis, vir doctus et asceticus, singulariter erga Parvulum Jesu pie affectus, scripsit „10 dierum recollectiones”, id opusculum posthumum extat Gedani praelo mandatum, seniculus, vir sanctitate insignis, obit. 10.04.1714 Posnaniae.

Eliseus à S. Joanne Baptista RP, Francoise Franciscus ${ }^{448}$, seniculus, nat. 14.05.1685, prof. 16.07.1713, obit. 27.10.1757 Plonscii.

Eliseus à S. Joanne Maliszewski RP ${ }^{449}$, concionator Polonorum, nat. 1780, prof. 1805, obit. 29.09.1813 Bidgostiae.

ściele parafialnym w Lubstowie z rąk sufragana gnieźnieńskiego Ignacego Bardzińskiego.

${ }^{437}$ AKKr 174/614, s. 2-3; Kart. 27, s. 412; AKKr 175/547, s. 341; Zak. 66: podana data zgonu 12 października 1794; Zak. 61, s. 199: podana data zgonu 18 lipca 1794; AAG, ACon G II 4, s. 29. Członek konwentu w Kłodawie w 1742. Święcenia prezbiteratu otrzymał 2 lipca 1742 w kaplicy Potockich w Gnieźnie z rąk sufragana gnieźnieńskiego Krzysztofa Dobińskiego.

${ }^{438}$ AKKr 175/547, s. 221; Zak. 66; Zak. 61, s. 110.

${ }^{439}$ AKKr 175/547, s. 731; Zak. 66.

${ }^{440} \mathrm{AKKr}$ 175/547, s. 63; Zak. 66; Zak. 61, s. 38: podana data zgonu 7 lutego 1684.

${ }^{441}$ AKKr 175/547, s. 41; Zak. 66; Zak. 61, s. 21.

${ }^{442}$ AKKr 174/614, s. 22-23: podana data zgonu 23 lipca 1791; Kart. 27, s. 415; AKKr 175/547, s. 397; Zak. 66; Zak. 61, s. 197.

${ }^{443}$ AKKr 175/547, s. 451; Zak. 66.

${ }^{444}$ AKKr 175/547, s. 315; Zak. 66; Zak. 61, s. 157.

${ }^{445}$ AKKr 175/547, s. 301; Zak. 66; Zak. 61, s. 151: podana data zgonu 31 maja 1690.

${ }^{446} \mathrm{AKKr} 174 / 614$, s. $2-3$ i 39; Kart. 27, s. 412: podana data urodzenia 6 marca 1716; AKKr 175/547, s. 177; Zak. 66; Zak. 61, s. 88.

${ }^{447}$ AKKr 175/547, s. 201; Zak. 66; Zak. 61, s. 100; Kroniczka, s. 6 i 188: przeor klasztoru Bożego Ciała w Poznaniu w 1686 i mistrz nowicjatu w 1702.

${ }^{448}$ AKKr 174/614, s. 34: podana data zgonu 9 października 1757; Kart. 27, s. 408; AKKr 175/547, s. 605; Zak. 66; Zak. 61, s. 274 i 292: podana druga data zgonu 9 października 1757.

${ }^{449}$ Zak. 66. 
Eliseus à S. Laurentio RP, Rybinski Laurentius ${ }^{450}$, nat. 13.08.1760, prof. 25.10.1784 Gedani, presb. 26.08.1787 Gedani, obit. 08.03.1810 Trutoviae.

Eliseus à S. Maria Magdalena de Pazzis RP, Welki Josephus ${ }^{451}$, nat. 02.02.1749, prof. 16.11.1766 Gedani, presb. 24.04.1773 Posnaniae, abiit in Provinciam Minoris Poloniae.

Eliseus à S. Stanislao Mrówczyński RP ${ }^{452}$, nat. 1795, prof. 1821, presb. 1822, obit. 23.06.1846 Guloviae.

Eliseus à S. Thadaeo $\mathrm{Fr}^{453}$, sutor, nat. 1699, prof. 1736, obit. 03.05.1739 Posnaniae.

Emilianus à S. Thoma RP, Gorecki Thomas ${ }^{454}$, ex concionator Polonorum, nat. 17.12.1767, prof. 20.07.1787 Posnaniae, obit. 13.04.1804 Plonscii.

Emilianus Księżniewski ARP ${ }^{455}$, concionator Ploscensis, prior Trutoviensis, parochus Miloscensis, nat. 1808, prof. 1838, obit. 23.04.1889 Miłonice.

Engelbertus à S. Michaele RP, Jazdzewski Michael ${ }^{456}$, actualis subprior loci, nat. 1732, prof. 28.11.1776, presbyter saecularis ingressus, beneficiatus, obit. 09.01.1803 Kcynae.

Epiphanius à Nativitate B.M.V. Fr Linkiewicz Michael Stanislaus ${ }^{457}$, nat. 1675, prof. 1697, obit. 29.08.1713 Oboriis.

Epiphanius à S. Alexandro RP ${ }^{458}$, promotor Confraternitis S. Annae, nat. 1711, prof. 1731, obit. 13.03.1740 Gedani.

${ }^{450}$ AKKr 174/614, s. 16-17 i 18-19; Zak. 66.

${ }^{451}$ AKKr 174/614, s. 10-11.

${ }^{452}$ AKKr 175/547, s. 351; Zak. 66.

${ }^{453}$ AKKr 175/547, s. 247; Zak. 66; Zak. 61, s. 123.

${ }^{454}$ AKKr 174/614, s. 18-19; AKKr 175/547, s. 207; Zak. 66; Zak. 61, s. 105: podana data zgonu 15 kwietnia 1804.

${ }^{455}$ AKKr 175/547, s. 227.

${ }^{456}$ Zak. 66; AKKr 175/547, s. 57: podana data zgonu 29 stycznia 1803; Zak. 61, s. 29: podana data zgonu 29 stycznia 1803; Nowicki, Stownik biograficzny, s. 91: brak informacji o miejscu ksztalcenia tego kapłana, prawdopodobnie kształcił się w Starych Szkotach. Święcenia kapłańskie otrzymał na podstawie prowizji na wikariat udzielonej mu przez plebana z Brus Piotra Nieżórawskiego 12 kwietnia 1758 roku. W 1760 był wikariuszem w Brusach. Nie notuje go wizytacja biskupa Antoniego Ostrowskiego. Dnia 5 września 1767 został instytuowany na beneficjum plebańskie w Wielu. Zrezygnował z beneficjum parafialnego w 1775; Archiwum Państwowe w Bydgoszczy, Klasztor karmelitów w Kcyni, sygn. 1, Acta die Verfassung des Karmeliter Klosters zu Kczyn auch die demsalben gehörigen Kapitalien betr, 1776-1795, syg. dawna C.1, k.196, s. 106, 110 i 111: urodził się na Pomorzu w miejscowości Skoraszew 26 września 1731; ADP, C 54a, s. 26 i 30: tonsurę i niższe święcenia otrzymał 17 grudnia 1757, święcenia subdiakonatu 23 lipca 1758, diakonatu 30 lipca 1758, prezbiteratu 6 sierpnia 1758 w Chełmży z rąk sufragana chełmińskiego Franciszka Fabiana Pląskowskiego: AKKr 174/614, s. 14-15: wstąpił do zakonu karmelitów 9 grudnia 1775 i złożył profesję zakonną 10 grudnia 1776. W latach 1782-1785 był kapelanem w klasztorze w Kcyni.

${ }^{457}$ AKKr 175/547, s. 487; Zak. 66; Zak. 61, s. 234: podana data zgonu 30 sierpnia 1713; TD, Grodzkie i ziemskie-Poznań-Inskrypcje-XVII/XVIII wiek, wpis nr 6108: syn Jana i Zofii Deręgowskiej. Członek konwentu Bożego Ciała w Poznaniu w 1702. Zapisał majątek po rodzicach swojemu konwentowi.

${ }^{458}$ AKKr 175/547, s. 145; Zak. 66; Zak. 61, s. 72; Zakonnicy, s. 334; Zawadzki, s. 316: w 1738 był duszpasterzem w Marynowach w części pomezańskiej diecezji chełmińskiej. 
Epiphanius à S. Saturnino Fr, Tokarski Joannes ${ }^{459}$, nat. 14.04.1716, prof. 03.12.1743, obit. 16.09.1766 Bidgostiae.

Erasmus à S. Andrea RP, Koperszmyth Andreas ${ }^{460}$, nat. 09.11.1766, prof. 03.08.1784 Gedani.

Erasmus à S. Jacobo RP, Witkowski Jacobus ${ }^{461}$, subprior loci, nat. 24.07.1714, presb. 1743, prof. 04.08.1764 Posnaniae, ex decano et parocho Znenensi, ingressus sacerdos saecularis, obit. 27.01.1782 Drohobiciis.

Erasmus à S. Joanne Nepomuceno ARP, Owidzki Thomas ${ }^{462}$, jubilatus, ex concionator Polonorum, secretarius provinciae, ex prior Oboriensis, actualis definitor provinciae, nat. 04.12.1718, prof. 20.08.1736, obit. 18.05.1760 sub manu medici Thorunii, sepultus Oboriis.

Erasmus à SS. Trinitatte ARP ${ }^{463}$, STL, jubilatus, sexennalis prior Posnanensis, electus vicarius provincialis, interfuit Capitulo Generali Romano celebrato, ubi titulum provincialis primus obtinuit, tandem prior loci, nat. 1685, prof. 1707, obit. 02.05.1737 Kcynae.

Eugenius à S. Eva $\mathrm{Fr}^{464}$, clericus perpetuus, studens philosophiae, nat. 1726, prof. 1755, obit. 01.05.1763 Gedani.

Eugenius à S. Nicolao RP, Gręca Nicolaus ${ }^{465}$, subprior loci, nat. 11.12.1757, prof. 23.12.1775 Gedani, presb. 22.02.1781 Posnaniae, obit. 14.01.1838 Kcynae.

Eugenius à S. Romano RP, Kraus Josephus ${ }^{466}$, musicus, vocalista, nat. 06.03.1712, prof. 10.08.1731, obit. 11.04.1754 Markovicae.

Eusebius à S. Adalberto ARP, Piekarski Adalbertus ${ }^{467}$, ex prior Bidgostiensis, prior loci, nat. 26.03.1761, prof. 02.01.1787 Gedani, presb. 06.01.1789 Plonscii, obit. 05.05.1825 Trutoviae.

Eusebius à S. Josepho RP, Moroszewski Adalbertus (Josephus) ${ }^{468}$, ex concionator Polonorum, actualis subprior loci, nat. 26.02.1711, prof. 21.09.1728 Gedani, presb. 03.01.1735 Gedani, obit. 11.02.1784 Bidgostiae.

${ }^{459}$ AKKr 174/614, s. 36: podana data zgonu 18 sierpnia 1766; Kart. 27, s. 416; AKKr 175/547, s. 523; Zak. 66; G. Kloskowski, Sylwetki ..., s.252: syn Jakuba i Konstancji Wielestowskiej. Jego brat Franciszek, w zak. Dominik (1718-1762) to cysters pelpliński.

${ }^{460}$ AKKr 174/614, s. 18-19.

${ }^{461}$ AKKr 174/614, s. 8-9 i 41: na stronie 41 podana data zgonu 18 marca 1782; AKKr 175/547, s. 33: podana druga data zgonu 17 stycznia 1782; Zak. 66: podana druga data zgonu 14 stycznia 1782.

${ }^{462}$ AKKr 174/614, s. 35; Kart. 27, s. 412; AKKr 175/547, s. 277; Zak. 66; Zak. 61, s. 138.

${ }^{463}$ AKKr 175/547, s. 245; Zak. 66; Zak. 61, s. 122; Kroniczka, s. 17-19 i 189: przeor klasztoru Bożego Ciała w Poznaniu w latach 1724 i 1727-1729.

${ }^{464}$ AKKr 174/614, s. 36; AKKr 175/547, s. 243; Zak. 66; Zak. 61, s. 121; Zakonnicy, s. 335: podana data zgonu 5 maja 1763 i imiona Eugenius à S. Leopoldo.

${ }^{465}$ AKKr 174/614, s. 14-15; AKKr 175/547, s. 27; Zak. 66; AAG, ACon G VI 11, s. 24v.

${ }^{466}$ AKKr 174/614, s. 33; Kart. 27, s. 411; AKKr 175/547, s. 203; Zak. 66; Zak. 61, s. 101; ADP, A 16, s. 33 i 42: członek konwentu w Kcyni w 1735. Święcenia subdiakonatu otrzymał 15 stycznia 1735 i diakonatu 17 grudnia 1735 w Chełmży z rąk sufragana chełmińskiego Macieja Aleksandra Sołtyka.

${ }^{467}$ AKKr 174/614, s. 18-19; AKKr 175/547, s. 251 i 271: na s. 271 podana data zgonu 15 maja 1825.

${ }^{468}$ AKKr 174/614, s. 2-3 i 42; Kart. 27, s. 410: podana data urodzenia 29 kwietnia 1711 i imię Józef. Prawdopodobnie pomyłka z zapisem sąsiednim; Zak. 66; AKKr 175/547, s. 83 i 85: drugi 
Eustachius à S. Adriano RP, Janiszewski Franciscus ${ }^{469}$, nat. 10.10.1723, prof. 12.09.1740 Posnaniae, presb. 24.06.1747 Kcynae, obit. 03.01.1791 Kcynae.

Eustachius à S. Aniceto RP ${ }^{470}$, lector philosophiae, nat. 1670, prof. 1689, obit. 06.09.1697 Gedani.

Eustachius à S. Cantio RP ${ }^{471}$, concionator Polonorum et dominicalis, nat. 1733, prof. 1753, obit. 18.07.1767 Klodaviae.

Eustachius à S. Philippo Głowiński ARP ${ }^{472}$, concionator, ex magister novitiorum, ex prior Bidgostiensis, actualis prior loci, ultimo loco [= Markowice] ruinosa tecta ecclesiae et aedificiorum totaliter restauravit, nat. 1766, prof. 1784, obit. 16.11.1826 Markovicae.

Eustachius à Venerabili Sacramento RP, Sobanski Stanislaus ${ }^{473}$, ex professor rhetorices, concionator Polonorum, nat. 21.09.1683, prof. 1700, obit. 10.10.1750 Trutoviae.

Euthymius à S. Josepho RP, Schultz Josephus ${ }^{474}$, nat. 1762, prof. 17.02.1780 Gedani, presb. 19.08.1787 Gedani.

Evaristus à S. Francisco Fr, Jankowski Franciscus ${ }^{475}$, nat. 04.10.1741, prof. 23.11.1762 Gedani.

Evaristus à S. Joanne RP, Szmuk Joannes ${ }^{476}$, nat. 06.12.1764, prof. 06.12.1784 Gedani, presb. 13.05.1787 Gedani.

Evaristus à S. Michaele RP, Rabski Michael ${ }^{477}$, ex lector philosophiae, concionator Polonorum bene commendatus, nat. 01.11.1744, prof. 26.10.1762 Gedani, presb. 06.01.1768 Varsaviae, obit. 13.02.1781 Gedani.

Evodius à S. Josepho ARP, Rahn Josephus ${ }^{478}$, ex prior Gedanensis, ex provincialis, ex commisarius generalis, ex profesor theologiae moralis, ex magister novitiorum, ex definitor et secretarius provinciae, prior Varsaviensis, nat. 16.01.1766, prof. 11.09.1785 Posnaniae, presb. 04.1789 Gedani, obit. 26.01.1836 Varsaviae.

zapis zgonu 12 lutego 1784; Zak. 61, s. 42; A. Mańkowski, Liber mortuorum ..., s. 85: konfrater cystersów koronowskich.

${ }^{469}$ AKKr 174/614, s. 4-5; Kart. 27, s. 413: podana data urodzenia 11 października 1723; AKKr 175/547, s. 5; Zak. 66; Zak. 61, s. 2: podana data zgonu 2 stycznia 1791.

${ }^{470}$ AKKr 175/547, s. 503; Zak. 66; Zak. 61, s. 258; ADP, A 41, s. 12: święcenia prezbiteratu otrzymał 18 grudnia 1694 w katedrze w Chełmży z rąk sufragana chełmińskiego Tomasza Skotnickiego.

${ }^{471}$ AKKr 174/614, s. 37; AKKr 175/547, s. 401; Zak. 66; Zak. 61, s. 199.

${ }^{472}$ AKKr 175/547, s. 647; Zak. 66: podana data zgonu 18 listopada 1825; AAG, ACon G VI 11, s. 17; ADP, C 54a, s. 165 i 166: członek konwentu w Gdańsku w 1796. Święcenia subdiakonatu otrzymał 13 lipca 1796, diakonatu 16 lipca 1796 i prezbiteratu 25 lipca 1796 w Chełmży z rąk sufragana chełmińskiego Iwona Onufrego Rogowskiego.

${ }^{473}$ AKKr 174/614, s. 32: podana data zgonu 5 października 1750; Kart. 27, s. 408: brak daty złożenia profesji zakonnej; AKKr 175/547, s. 571; Zak. 66; Zak. 61, s. 268: podana data zgonu 3 października 1750.

${ }^{474}$ AKKr 174/614, s. 16-17.

${ }^{475}$ AKKr 174/614, s. 24-25.

${ }^{476}$ AKKr 174/614, s. 18-19; Nowicki, Stownik biograficzny, s. 210: w latach 1796-1799 był komendariuszem w Tyłowie.

${ }^{477}$ AKKr 174/614, s. 8-9 i 41: na s. 41 podana data zgonu 13 stycznia 1781; Zak. 66: podana data zgonu 14 lutego 1781; AKKr 175/547, s. 87; Zak. 61, s. 44; Zakonnicy, s. 336: podana data zgonu 14 lutego 1781.

${ }^{478}$ AKKr 174/614, s. 18-19; AKKr 175/547, s. 51; Zak. 66. 
Expeditus à S. Christiano RP, Skok Christianus ${ }^{479}$, emeritus, concionator, cantor, actualis subprior loci, nat. 10.09.1741, prof. 15.06.1761 Gedani, presb. 11.11.1764 Bidgostiae, obit. 12.04.1800 Trutoviae.

Fabianus à S. Josepho RP, Glonka Josephus ${ }^{480}$, nat. 25.05.1768, prof. 1788 Gedani.

Fabianus à S. Valentino RP, Winkler Valentinus ${ }^{481}$, bis primitians, organarius tam choralis quam figuralis eximius, multa pro gloria Dei scripsit, nat. 10.02.1701, prof. 06.08.1719 Gedani, presb. 15.08.1726 Varsaviae, obit. 21.12.1775 Bidgostiae.

Faustinus à S. Ambrosio RP, Lewski Ambrosius ${ }^{482}$, nat. 09.04.1757, prof. 08.10.1776 Gedani, presb. 01.01.1781 Varsaviae.

Faustinus à S. Saturnino RP ${ }^{483}$, musicus, vocalista, sacrista, nat. 1736, prof. 1757, presb. 1761, obit. 03.07.1770 Posnaniae.

Faustinus à S. Stanislao Fr, Kuczwalski Stanislaus ${ }^{484}$, nat. 1750, prof. 04.03.1779 Posnaniae, obit. 24.05.1806 Bidgostiae.

Faustinus à S. Vincentio RP, Gurski Paulus ${ }^{485}$, STL, concionator Polonorum, subprior loci, nat. 29.01.1713, prof. 19.02.1730, obit. 05.02.1753 Posnaniae.

Faustus à S. Francisco RP ${ }^{486}$, tibicen, sacrista, musicus, nat. 1736, prof. 1755, obit. 21.07.1773 Kcynae.

Faustus à S. Josepho RP, Fetter Josephus ${ }^{487}$, musicus, studens theologiae, nat. 07.11.1726, prof. 08.10.1743, obit. 28.04.1752 Varsaviae.

Felicianus à S. Felice Mądrzycki Fr ${ }^{488}$, pluribus annis sacrista conventus Varsaviensis, terminarius bene meritus, nat. 1808, prof. 1829, obit. 19.11.1869 Varsaviae.

${ }^{479}$ AKKr 174/614, s. 8-9; AKKr 175/547; s. 205; Zak. 66; Zak. 61, s. 102; ADP, C 54a, s. 59 i 60: członek konwentu w Bydgoszczy w 1764. Tonsurę i niższe święcenia otrzymał 22 września 1764, subdiakonatu 28 października 1764, diakonatu 1 listopada 1764 i prezbiteratu 4 listopada 1764 w Chełmży. Szafarzem wszystkich święceń był sufragan chełmiński Franciszek Fabian Pląskowski; Kroniczka, s. 90, 163-164, 194 i 196: student teologii z klasztoru Bożego Ciała w Poznaniu w 1766 i 1767. Przebywał w rezydencji przy kościele Najświętszej Krwi Pana Jezusa w Poznaniu w kwietniu 1768.

${ }^{480}$ AKKr 174/614, s. 18-19.

${ }^{481}$ AKKr 174/614, s. 2-3 i 39: na s. 3 data zgonu 23 listopada 1775; Kart. 27, s. 409: podana data złożenia profesji zakonnej 1 grudnia 1720; AKKr 175/547, s. 715; Zak. 66; Mańkowski, Liber mortuorum, s. 65: konfrater cystersów koronowskich.

${ }^{482}$ AKKr 174/614, s. 14-15.

${ }^{483}$ AKKr 174/614, s. 37; AKKr 175/547, s. 371; Zak. 66; Zak. 61, s. 184; ADP, C 54a, s. 29: członek konwentu w Gdańsku w 1758. Tonsurę i niższe święcenia otrzymał 11 czerwca 1758 w Kartuzach z rąk sufragana chełmińskiego Franciszka Fabiana Pląskowskiego.

${ }^{484}$ AKKr 174/614, s. 26-27; Zak. 66; Zak. 61, s. 144; Mańkowski, Liber mortuorum, s. 139: konfrater cystersów koronowskich.

${ }^{485}$ AKKr 174/614, s. 33; Kart. 27, s. 411; AKKr 175/547, s. 71; Zak. 66; Zak. 61, s. 36.

${ }^{486}$ AKKr 174/614, s. 38: podana data zgonu 20 marca 1773; AKKr 175/547, s. 407: podane imiona zakonne Faustus à S. Francisco Carolus; Zak. 66; Zak. 61, s. 79 i 202: podana druga data zgonu 20 marca 1773; ADP, C 54a, s. 29: członek konwentu w Gdańsku w 1758. Tonsurę i niższe święcenia otrzymał 11 czerwca 1758 w Kartuzach z rąk sufragana chełmińskiego Franciszka Fabiana Pląskowskiego.

${ }^{487}$ AKKr 174/614, s. 33; Kart. 27, s. 414; AKKr 175/547 s. 237; Zak. 66; Zak. 61, s. 118.

${ }^{488}$ AKKr 175/547, s. 651. 
Felicianus à S. Jacobo RP, Andrzejewski Jacobus ${ }^{489}$, actualis [a] multis annis subprior loci, nat. 16.07.1738, prof. 22.10.1758 Posnaniae, presb. 1762 Gedani, obit. 17.03.1808 Posnaniae.

Felicianus à S. Joanne Nepomuceno Kubalski ARP ${ }^{490}$, ex prior Oboriensis et Klodaviensis, Ex Definitor, nat. 1788, prof. 1809, presb. 1814, obit. 24.01.1850 Guloviae.

Felicianus à S. Michaele Fr, Urzyczkowski (Wryczkowski) Michael $^{491}$, sartor, nat. 29.09.1755, prof. 03.10.1776 Gedani, obit. 16.08.1818 Plonscii.

Felicianus à S. Stephano ARP, Draminski Stephanus ${ }^{492}$, ex definitor, ex prior Plonscensis et Trutoviensis, actualis prior loci, nat. 03.08.1702, prof. 06.02.1722, obit. 16.02.1755 Drohobiciis.

Felix à Presentatione B.M.V. Fr ${ }^{493}$, diaconus, nat. 1700, prof. 1717, obit. 19.11.1723 Posnaniae.

Felix à S. Antonio Fr, Miller Antonius ${ }^{494}$, terminarius, nat. 25.01.1724, prof. 19.07.1753 Gedani, obit. 12.02.1799 Bidgostiae.

Felix à S. Bernardo RP, Huhn Jacobus ${ }^{495}$, subprior loci, nat. 30.04.1703, prof. 21.08.1725, obit. 15.03.1753 Markovicae.

Felix à $S$. Joanne $\rightarrow$ Felix à S. Antonio

Felix à S. Joanne RP, Schmitt Joannes ${ }^{496}$, nat. 21.04.1738, prof. 05.08.1765 Gedani, presb. 25.12.1769 Posnaniae, obit. 10.10.1795 Posnaniae.

Felix à S. Simone ARP, Zawadzki Michael ${ }^{497}$, actualis prior loci, nat. 17.09.1719, prof. 05.09.1737, obit. 11.07.1759 Drohobiciis. naniae.

Felix à Transfiguratione Domini Fr ${ }^{498}$, nat. 1630, prof. 1652, obit. 05.09.1680 Pos-

${ }^{489}$ AKKr 174/614, s. 6-7; AKKr 175/547, s. 153; Zak. 66; Zak. 61, s. 76; ADWł, ABSWł 10, s. 12; ADP, C 54a, s. 48: członek konwentu w Bydgoszczy w 1761 i w Gdańsku w 1762. Tonsurę i niższe święcenia otrzymał 28 października 1761 w kościele klarysek w Bydgoszczy z rąk sufragana włocławskiego Jana Dembowskiego. Święcenia subdiakonatu otrzymał 12 kwietnia 1762 i diakonatu 18 kwietnia 1762 w Chełmży z rąk sufragana chełmińskiego Franciszka Fabiana Pląskowskiego.

${ }^{490}$ AKKr 175/547, s. 47; Zak. 66.

${ }^{491}$ AKKr 174/614, s. 26-27; AKKr 175/547, s. 459; Zak. 66.

${ }^{492}$ AKKr 174/614, s. 33; Kart. 27, s. 409; AKKr 175/547, s. 93; Zak. 66; Zak. 61, s. 47.

${ }^{493}$ AKKr 175/547, s. 651; Zak. 66; Zak. 61, s. 121 i 316: podane daty zgonu 1 maja 1724 i 20 listopada 1723.

${ }^{494} \mathrm{AKKr}$ 174/614, s. 22-23; Zak. 66: podana data zgonu 11 lutego 1799 oraz imiona zakonne Felix à S. Joanne; Zak. 61, s. 43.

${ }^{495}$ AKKr 174/614, s. 33; Kart. 27, s. 410; AKKr 175/547, s. 149; Zak. 66; Zak. 61, s. 74; Braniewo, s. 78 (wpis nr 1706): syn Michała i Doroty. Urodził się w Pieniężnie na Warmii. Od 1 września 1717 kształcił się w gimnazjum jezuickim w Braniewie; Kroniczka, s. 201: przebywał w rezydencji przy kościele Najświętszej Krwi Pana Jezusa w Poznaniu w 1735.

${ }^{496}$ AKKr 174/614, s. 8-9; AKKr 175/547, s. 571; Zak. 66; Zak. 61, s. 275; ADP, C 54a, s. 70 (podane imiona Feliks od Św. Jana Baptysty): członek konwentu w Bydgoszczy w 1767. Święcenia subdiakonatu otrzymał 19 września 1767 w Chełmży z rąk sufragana chełmińskiego Franciszka Fabiana Pląskowskiego.

${ }^{497}$ AKKr 174/614, s. 34; Kart. 27, s. 412; AKKr 175/547, s. 387; Zak. 66; Zak. 61, s. 192.

${ }^{498}$ AKKr 175/547, s. 501; Zak. 66; Zak. 61, s. 240. 
Ferdinandus à S. Cassiano ARP, Szweykowski Balthasar ${ }^{49}$, jubilatus, emeritus, concionator, sexennalis ex prior Klodaviensis, nec non principalis restaurator ecclesiae Klodaviensis, nat. 12.01.1713, prof. 10.08.1731, obit. 12.05.1761 Posnaniae.

Ferdinandus à S. Joanne RP, Wallis Joannes ${ }^{500}$, nat. 04.1740, prof. 22.08.1767 Posnaniae, presb. 1770 Posnaniae.

Florentius à S. Henrico ARP ${ }^{501}$, ex vicarius provinciae, obit. 14.02.1692 Bidgostiae.

Florentius à S. Joanne à X. RP, Niemczewski Joannes ${ }^{502}$, actualis concionator loci, nat. 27.11.1764, prof. 09.10.1783 Posnaniae, presb. 01.01.1789 Plonscii, obit. 13.05.1800 Klodaviae.

Florentius à S. Teresia ARP, Arent Andreas ${ }^{503}$, bis primitians, concionator Germanorum, magister novitiorum, secretarius provinciae, praeses capituli, ex prior Gedanensis, Drohobicensis et Kcynensis, nat. 20.11.1666, prof. 23.10.1690, obit. 09.02.1746 Trutoviae.

Florentius à S. Thelesphoro ARP, Kami(e)nski Thelesphorus ${ }^{504}$, concionator, emeritus, ex prior Posnaniensis, Markovicensis et Bidgostiensis, bis ex definitor, nat. 22.01.1722, prof. 13.10.1739 Posnaniae, presb. 10.09.1745 Posnaniae, obit. 04.06.1782 Kcynae.

Florianus à S. Antonio Fr, Hertog Antonius ${ }^{505}$, nat. 13.08.1748, prof. 06.11.1774 Posnaniae, obit. 22.01.1826 Posnaniae.

Florianus à S. Cruce ARP ${ }^{506}$, ex prior Posnaniensis, ex prior loci, nat. 1640, prof. 1661, obit. 01.10.1689 Bidgostiae.

Florianus à S. Henrico RP, Szulc Henricus ${ }^{507}$, emeritus, concionator, ex lector philosophiae, nat. 13.07.1751, prof. 14.07.1767 Gedani, presb. 23.07.1770 Gedani, obit. 17.05.1793 Bidgostiae.

Florianus à S. Joanne Evangelista RP ${ }^{508}$, nat. 1675, prof. 1695, obit. 13.10.1709 Varsaviae.

Florianus à S. Paulo RP ${ }^{509}$, sacrista, nat. 1704, prof. 1732, obit. 08.05.1738 Kcynae.

${ }^{499}$ AKKr 174/614, s. 35; Kart. 27, s. 411; AKKr 175/547, s. 265; Zak. 66; Zak. 61, s. 131: podana data zgonu 11 maja 1761.

${ }^{500}$ AKKr 174/614, s. 10-11.

${ }^{501}$ AKKr 175/547, s. 89; Zak. 66.

${ }^{502}$ AKKr 174/614, s. 16-17; AKKr 175/547, s. 267; Zak. 66; Zak. 61, s. 133: podane miejsce zgonu Krośniewice w dekanacie kłodawskim diecezji gnieźnieńskiej.

${ }^{503}$ AKKr 174/614, s. 31; Kart. 27, s. 407; AKKr 175/547, s. 79; Zak. 66; Zak. 61, s. 40.

${ }^{504}$ AKKr 174/614, s. 2-3 i 41; Kart. 27, s. 413: podana data urodzenia 5 stycznia 1722; AKKr 175/547, s. 311; Zak. 66.

${ }^{505}$ AKKr 174/614, s. 26-27; AKKr 175/547, s. 43.

${ }^{506} \mathrm{AKKr}$ 175/547, s. 553; Zak. 66; Zak. 61, s. 267: podana data zgonu 2 października 1689 oraz imiona zakonne Florianus à $\mathrm{S}$. Venceslao.

${ }^{507}$ AKKr 174/614, s. 10-11: podana data zgonu 20 maja 1793; AKKr 175/547, s. 275; Zak. 66; Zak. 61, s. 137 i 138: zapis zgonu z datą 17 maja 1793 przekreślony i podana data zgonu 18 maja 1793.

${ }^{508} \mathrm{AKKr}$ 175/547, s. 577; Zak. 66: podana data zgonu 14 października 1709; Zak. 61, s. 278: podana data zgonu 13 października 1710; ADP, A 41, s. 18 i 22v: członek konwentu w Bydgoszczy w latach 1697-1698. Święcenia subdiakonatu otrzymał 21 grudnia 1697 i diakonatu 24 maja 1698 w katedrze w Chełmży z rąk sufragana chełmińskiego Tomasza Skotnickiego.

${ }^{509}$ AKKr 175/547, s. 257; Zak. 66; Zak. 61, s. 128. 
Florianus à S. Urbano Fr, Kosmalewicz Antonius ${ }^{510}$, sartor, nat. 13.01.1713, prof. 06.06.1739, obit. 08.01.1766 Lipiae.

Florianus à $\mathrm{S}$. Venceslao $\rightarrow$ Florianus à $\mathrm{S}$. Cruce

Fortunatus à S. Angelo $\mathrm{Fr}^{511}$, nat. 1646, prof. 1668, obit. 18.08.1686 Posnaniae.

Fortunatus à S. Francisco ARP, Lesman (Lesnau) Franciscus ${ }^{512}$, pluribus annis prior Posnaniensis, ex magister novitiorum, ex definitor provinciae, nat. 16.09.1769, prof. 24.10.1786 Gedani, presb. 1793, obit. 24.11.1833 Posnaniae.

Fortunatus à S. Joachimo ARP, Holtz Joachimus ${ }^{513}$, STL, jubilatus, ex definitor, aliquoties prior Bidgostiensis et actualis, nat. 05.04.1731, prof. 31.08.1750 Gedani, presb. 25.01.1756 Posnaniae, obit. 11.06.1782 Bidgostiae.

Fortunatus à S. Joanne Fr, Szramowski Joannes ${ }^{514}$, oeconomus bene commendatus, nat. 1763, prof. 13.07.1785 Posnaniae, obit. 20.10.1809 Posnaniae.

Fortunatus à S. Maria Magdalena de Pazzis RP ${ }^{515}$, musicus, nat. 1728, prof. 1749, obit. 29.06.1761 Trutoviae.

Fortunatus à S. Stanislao $\mathrm{Fr}^{516}$, clericus, studens philosophiae, nat. 1727, prof. 1745, obit. 28.07.1749 Gedani.

Fortunatus Drzniowski $\mathrm{Fr}^{517}$, obit. 06.09.1809 Kcynae.

Fortunatus Jajko ARP ${ }^{518}$, ex prior Guloviensis, ex definitor, nat. 1825, prof. 1847, presb. 1850, obit. 11.01.1911 Oboriis.

Franciscus à S. Adalberto Karwaszewski ARP ${ }^{519}$, ex prior Klodaviensis, Plonscensis et Trutoviensis, nat. 1780, prof. 1809, presb. 1810, obit. 08.09.1852 Friedrichsdorf.

Franciscus à S. Antonio Fr, Rokicki Thaddaeus ${ }^{520}$, clericus perpetuus, nat. 20.03.1743, prof. 03.07.1766 Posnaniae, obit. 23.12.1780 Oboriis.

Franciscus à S. Jacobo RP, Grabowicz Jacobus ${ }^{521}$, subprior loci, nat. 27.07.1751, prof. 26.12.1777 Posnaniae, presb. 04.02.1780 Gedani, obit. 18.01.1805 Plonscii.

Franciscus à S. Joanne Fr, Majewski Joannes ${ }^{522}$, tibicen, nat. 04.03.1727, prof. 17.08.1756 Gedani, obit. 14.05.1794 Oboriis.

Franciscus à S. Joanne $\mathrm{Fr}^{523}$, nat. 1651, prof. 1673, obit. 11.08.1709 Posnaniae.

${ }^{510}$ AKKr 174/614, s. 36; Kart. 27, s. 415; AKKr 175/547, s. 15; Zak. 66; Zak. 61, s. 8.

${ }^{511}$ AKKr 175/547, s. 463; Zak. 66; Zak. 61, s. 239: przekreślony zapis zgonu z datą 4 września 1686.

${ }^{512}$ AKKr 174/614, s. 18-19; Zak. 66.

${ }^{513}$ AKKr 174/614, s. 6-7 i 41; AKKr 175/547, s. 325; Zak. 66; Mańkowski, Liber mortuorum, s. 80: konfrater cystersów koronowskich.

${ }^{514}$ AKKr 174/614, s. 28; AKKr 175/547, s. 591; Zak. 66: podana data zgonu 3 września 1809 Kcynia.

${ }^{515}$ AKKr 174/614, s. 35; AKKr 175/547, s. 357; Zak. 66; Zak. 61, s. 180.

${ }^{516}$ AKKr 174/614, s. 32; AKKr 175/547, s. 421; Zak. 66; Zak. 61, s. 209; Zakonnicy, s. 334.

${ }^{517}$ Zak. 61, s. 241.

${ }^{518}$ AKKr 175/547, s. 21.

${ }^{519}$ Zak. 66.

${ }^{520}$ AKKr 174/614, s. 10-11 i 41; AKKr 175/547, s. 719; Zak. 66.

${ }^{521}$ AKKr 174/614, s. 14-15; Zak. 66; AKKr 175/547, s. 35: na s. 33 odnotowany błędny zapis, że Ojciec Franciscus à S. Jacobo Dąbrowicz zmarł 16 stycznia 1805 w Płońsku; Zak. 61, s. 18.

${ }^{522}$ AKKr 174/614, s. 22-23: podana data zgonu 15 maja 1794; AKKr 175/547, s. 269; Zak. 61, s. 134.

${ }^{523}$ AKKr 175/547, s. 449; Zak. 66. 
Franciscus à S. Josepho RP, Kembłowski Antonius ${ }^{524}$, procurator loci, nat. 11.07.1717, prof. 13.10.1739, presb. 1746, obit. 05.04.1762 Kcynae.

Franciscus à S. Martiniano $\mathrm{Fr}^{525}$, nat. 1667, prof. 1686, obit. 28.03.1709 Gedani.

Franciscus à S. Michaele Fr ${ }^{526}$, nat. 1645, prof. 1667, obit. 18.01.1691 Posnaniae.

Franciscus ab Immaculata Conceptione B.V.M. ARP, Zaluski Michael ${ }^{527}$, concionator, 40 annis syndicus generalis provinciae, nat. 24.09.1686, prof. 08.12.1702, obit. 17.06.1754 Posnaniae.

Franciscus Clemens à $\mathrm{S}$. Josepho $\rightarrow$ Clemens à $\mathrm{S}$. Josepho

Francus à S. Alberto Fr, Jankowski Albertus ${ }^{528}$, terminarius, oeconomus, nat. 1706, prof. 22.03.1733, obit. 22.02.1766 Markovicae.

Francus à S. Ambrosio $\mathrm{Fr}^{529}$, terminarius, benemeritus, nat. 1689, prof. 1713, obit. 04.05.1729 Gedani.

Francus à S. Benedicto $\mathrm{Fr}^{530}$, seniculus, obit. 07.08.1667 Gedani.

Francus à S. Brunone RP ${ }^{531}$, nat. 1654, prof. 1684, obit. 17.01.1708 Drohobiciis.

Francus à S. Ignatio RP, Kamalski Ignatius ${ }^{532}$, nat. 04.08.1740, prof. 15.12.1761 Posnaniae, presb. 09.11.1766 Kcynae.

Francus à S. Joanne Evangelista RP ${ }^{533}$, pictor, obit. 20.06.1708 Kcynae.

Francus à S. Joanne $\mathrm{Fr}^{534}$, terminarius, bene meritus, nat. 1723, prof. 1756, obit. 09.05.1771 Markovicae.

Francus à S. Michaele Fr, Schmid Michael ${ }^{535}$, murarius, nat. 02.06.1748, prof. 29.12.1772 Posnaniae, obit. 25.12.1787 Kcynae.

Francus à S. Norberto Fr, Kamieniecki Petrus ${ }^{536}$, seniculus, nat. 29.06.1689, prof. 21.07.1734, obit. 29.05.1755 Oboriis.

Francus à S. Teresia $\mathrm{Fr}^{537}$, nat. 1650, prof. 1672, obit. 28.02.1692 Posnaniae.

Francus à S. Thoma RP ${ }^{538}$, nat. 1659, prof. 1678, obit. 20.06.1708 Drohobiciis.

${ }^{524}$ AKKr 174/614, s. 35; Kart. 27, s. 413; AKKr 175/547, s. 191; Zak. 66; Zak. 61, s. 95.

${ }^{525} \mathrm{AKKr} 175 / 547$, s. 175; Zak. 66: podany rok złożenia profesji 1688; Zak. 61, s. 87.

${ }^{526}$ AKKr 175/547, s. 35; Zak. 66; Zak. 61, s. 18.

${ }^{527}$ AKKr 174/614, s. 33; Kart. 27, s. 407; AKKr 175/547, s. 105; Zak. 66; Zak. 61, s. 168; ADP, A 41, s. 27v: członek konwentu w Gdańsku w 1707. Święcenia subdiakonatu otrzymał 24 września 1707 w katedrze w Chełmży z rąk sufragana chełmińskiego Seweryna Szczuki; Kroniczka, s. 23 i 190: prokurator konwentu Bożego Ciała w Poznaniu w latach 1714-1732. Syndyk prowincji. Ułożył kopiariusz dokumentów klasztoru Bożego Ciała w 1740.

${ }^{528}$ AKKr 174/614, s. 36; Kart. 27, s. 415: brak pełnej daty urodzenia; AKKr 175/547, s. 105; Zak. 66; Zak. 61, s. 53.

${ }^{529}$ AKKr 175/547, s. 249; Zak. 66; Zak. 61, s. 124.

${ }^{530}$ AKKr 175/547, s. 441; Zak. 66; Zak. 61, s. 216: podana data zgonu 4 sierpnia 1676.

${ }^{531}$ AKKr 175/547, s. 33; Zak. 66; Zak. 61, s. 17.

${ }^{532}$ AKKr 174/614, s. 8-9.

${ }^{533}$ Zak. 61, s. 171.

${ }^{534}$ AKKr 174/614, s. 38; AKKr 175/547, s. 635: podana data zgonu 11 listopada 1771; Zak. 66: podana data zgonu 11 listopada 1771; Zak. 61, s. 129, 208 i 307: podane również daty zgonu 27 lipca w Poznaniu, brak roku oraz 11 listopada 1771.

${ }^{535}$ AKKr 174/614, s. 24-25; AKKr 175/547, s. 723; Zak. 66.

${ }^{536}$ AKKr 174/614, s. 33: podana data zgonu 28 maja 1755; Kart. 27, s. 415; AKKr 175/547, s. 299; Zak. 66; Zak. 61, s. 146: podana data zgonu 26 maja 1755.

${ }^{537}$ AKKr 175/547, s. 117; Zak. 66; Zak. 61, s. 59.

${ }^{538}$ AKKr 175/547, s. 345; Zak. 66. 
Francus à SS. Simone \& Juda RP, Straus Andreas ${ }^{539}$, concionator Polonorum, nat. 12.11.1692, prof. 30.10.1716, obit. 04.10.1748 Markovicae.

Franquillinus à S. Dominico RP, Kowalkowski Dominicus ${ }^{540}$, ex concionator Polonorum, nat. 03.08.1763, prof. 22.02.1781 Gedani, presb. 01.10.1786 Varsaviae, obit. 12.02.1808 Lipiae.

Fulgentius à S. Gerardo RP $\mathrm{P}^{541}$, ex prior, nat. 1655, prof. 1674, obit.20.12.1697 Posnaniae.

Fulgentius à S. Joanne à Cruce RP, Hypnarski Joannes ${ }^{542}$, seniculus, nat. 22.04.1689, prof. 19.11.1714, obit. 11.09.1751 Drohobiciis.

Fulgentius à S. Petro RP, Lewinski Petrus ${ }^{543}$, ex concionator Polonorum, nat. 15.08.1738, prof. 06.05.1755 Gedani, presb. 11.04.1762 Posnaniae, obit. 02.06.1792 Markovicae.

Fulgentius Nowaczewski ARP ${ }^{544}$, ex prior Oboriensis, Wąsosensis et Guloviensis, ex definitor, ex subprior Wąsosensis et Lipinensis, decanus Ciechanoviensis, parochus Zeńbok, nat. 1801, prof. 1826, presb. 1828, obit. 08.02.1871 Zeńbok.

Gabriel à S. Andrea $\rightarrow$ Gabriel à $S$. Luca

Gabriel à S. Antonio ARP, Nowogorski Antonius ${ }^{545}$, concionator Polonorum, ex prior Markovicensis, ex prior loci, nat. 20.11.1691, prof. 18.01.1711, obit. 02.09.1758 Plonscii.

Gabriel à S. Cyrillo ARP, Koslinski Paulus ${ }^{546}$, ex vicarius provincialis, ex prior Bidgostiensis, Gedanensis et Posnaniensis, praesidens oratorii Posnaniensis, nat. 07.02.1674, prof. 04.03.1690, obit. 26.02.1751 Posnaniae.

Gabriel à S. Joanne Baptista RP, Zaiąkalski Joannes ${ }^{547}$, concionator Polonorum, nat. 10.06.1730, prof. 05.07.1757 Gedani, presb. 20.07.1761 Posnaniae, obit. 12.02.1789 Klodaviae.

Gabriel à S. Josepho $\mathrm{Fr}^{548}$, clericus novitius, nat. 1691, obit. 29.06.1709 Gedani.

${ }^{539}$ AKKr 174/614, s. 32: podana data zgonu 4 października 1749; Kart. 27, s. 409; AKKr 175/547, s. 559; Zak. 66; Zak. 61, s. 269: podana data zgonu 4 października 1749.

${ }^{540}$ AKKr 174/614, s. 16-17; AKKr 175/547, s. 85; Zak. 66: podana data zgonu 3 marca 1808; Zak. 61, s. 43.

${ }^{541}$ AKKr 175/547, s. 713; Zak. 66.

${ }^{542}$ AKKr 174/614, s. 32: podana data zgonu 12 września 1751; Kart. 27, s. 408; AKKr 175/547, s. 513; Zak. 66; Zak. 61, s. 247: podana data zgonu 12 września 1751. Zmarł jako kapelan w kościele parafii Turobin, będąc zakonnikiem konwentu w Drohobyczu.

${ }^{543}$ AKKr 174/614, s. 6-7; AKKr 175/547, s. 335: podana data zgonu 15 czerwca 1792; Zak. 66; Zak. 61, s. 153; Kroniczka, s. 30 i 190: kaznodzieja rezydencji przy kościele Najświętszej Krwi Pana Jezusa w Poznaniu od sierpnia 1763. Przebywał następnie w klasztorze w Oborach.

${ }^{544}$ AKKr 175/547, s. 77

${ }^{545}$ AKKr 174/614, s. 34: podana data zgonu 7 września 1758; Kart. 27, s. 408; AKKr 175/547, s. 495; Zak. 66; Zak. 61, s. 242: podana data zgonu 7 września 1758.

${ }^{546}$ AKKr 174/614, s. 32; Kart. 27, s. 407; AKKr 175/547, s. 113; Zak. 66; Zak. 61, s. 57; Kroniczka, s. 14, 19, 23, 102 i 189: podprzeor w klasztorze Bożego Ciała w Poznaniu, a następnie przeor w latach 1722-1723 i 1733. Czwarty przełożony rezydencji przy kościele Najświętszej Krwi Pana Jezusa w Poznaniu. Definitor prowincji w 1733. Potem w klasztorze w Bydgoszczy. Pierwszy prezydent rezydencji przy kościele Najświętszej Krwi Pana Jezusa w Poznaniu do śmierci w 1751.

${ }^{547}$ AKKr 174/614, s. 6-7; AKKr 175/547, s. 85; Zak. 66; Zak. 61, s. 43.

${ }^{548}$ AKKr 175/547, s. 363; Zak. 66; Zak. 61, s. 83 i 180: podana druga data zgonu 24 marca 1710. 
Gabriel à S. Luca Fr, Sekulski Andreas ${ }^{549}$, seniculus, sartor, hostis otii, in operando assiduus usque ad provectam aetatem, nat. 28.11.1692, prof. 1723, obit. 19.10.1772 Trutoviae.

Gabriel Robota $\mathrm{RP}^{550}$, oriundus e Silesia, concionator, tempore belli europeici 1914 anno orti adscriptus exercitibus germanicis, munus capellani castrensis suscipiens, laudabiliter complevit. Sacerdos assiduus in labore, fungebatur officio cooperatoris in Bołszowce. Translocatus in Conventum Leopoliensem, die 19 Martii 1936 paralisi progressivo affectus, heroica patientia aerumnas morbi perpessus est, nat. 1880, prof. 1901, presb. 1906, obit. 02.07.1936 Leopoli.

Gaspar à SS. Angelis RP, Kuhn Laurentius ${ }^{551}$, nat. 10.08.1722, prof. 12.10.1743 Gedani, presb. 08.05.1750 Kcynae, obit. 13.06.1780 Drohobiciis.

Georgius à S. Antonio RP, Jankowski Antonius ${ }^{552}$, concionator Polonorum, nat. 30.01.1758, prof. 14.03.1775 Gedani, presb. 30.04.1776 Klodaviae, obit. 29.03.1793 Varsaviae.

Georgius à S. Clemente RP ${ }^{553}$, concionator Polonorum, nat. 1655, prof. 1675, obit. 13.04.1704 Oboriis.

Georgius à S. Fabiano Fr, Brocki Fabianus ${ }^{554}$, sartor, nat. 19.01.1749, prof. 23.04.1769 Posnaniae, obit. 05.01.1816 Trutoviae.

Georgius à S. Laurentio RP, Wyganowski Laurentius ${ }^{555}$, seniculus, nat. 10.08.1698, prof. 13.04.1719, obit. 25.05.1771 Oboriis.

Georgius à S. Martino $\mathrm{Fr}^{556}$, nat. 1694, prof. 1716, obit. 19.03.1733 Klodaviae.

Georgius à $\mathbf{S}$. Sebastiano $\rightarrow$ Georgius à $\mathbf{S}$. Fabiano

Gerardus à Nomine Jezu RP $\mathrm{P}^{557}$, nat. 1658, prof. 1677, obit. 30.09.1688 Bidgostiae.

Gerardus à S. Anastasio RP ${ }^{558}$, nat. 1668, prof. 1690, obit. 01.11.1706 Bidgostiae.

Gerardus à S. Antonio $\rightarrow$ Gerardus à $S$. Anastasio

Gerardus à S. Jacobo ARP, Wysocki Jacobus ${ }^{559}$, ex concionator Polonorum, ex prior Bidgostiensis, Plonscensis et Klodaviensis, nec non secretarius provinciae, clausit ultimum diem, nat. 30.04.1690, prof. 26.02.1709, presb. 1713, obit. 26.03.1762 Posnaniae.

${ }^{549}$ AKKr 174/614, s. 38; Kart. 27, s. 415: brak pełnej daty złożenia profesji zakonnej i podane imiona zakonne Gabriel à S. Andrea; AKKr 175/547, s. 589; Zak. 66; Zak. 61, s. 283: podana data zgonu 18 października 1772 oraz imiona zakonne Gabriel à S. Andrea.

${ }^{550}$ AKKr 175/547, s. 369.

${ }^{551}$ AKKr 174/614, s. 4-5 i 41; Kart. 27, s. 414: podana data urodzenia 11 sierpnia 1722 i data złożenia profesji zakonnej 17 października 1743; AKKr 175/547, s. 329; Zak. 66; Zak. 61, s. 164.

${ }^{552}$ AKKr 174/614, s. 14-15; AKKr 175/547, s. 177; Zak. 66: podana data zgonu 28 marca 1793; Zak. 61, s. 88: brak roku śmierci.

${ }^{553}$ AKKr 175/547, s. 207; Zak. 66; Zak. 61, s. 103.

${ }^{554}$ AKKr 174/614, s. 24-25; Zak. 66; AKKr 175/547, s. 139 i 243: podane daty zgonu 10 marca, 1 maja 1816 oraz s. 1873 kwietnia 1816 oraz imiona zakonne Georgius à S. Sebastiano.

${ }^{555}$ AKKr 174/614, s. 38; Kart. 27, s. 409; AKKr 175/547, s. 291; Zak. 66; Zak. 61, s. 145.

${ }^{556}$ AKKr 175/547, s. 157; Zak. 66; Zak. 61, s. 78.

${ }^{557}$ AKKr 175/547, s. 551; Zak. 66; Zak. 61, s. 256: podana data zgonu 20 września 1688.

${ }^{558} \mathrm{AKKr}$ 175/547, s. 615; Zak. 66; Zak. 61, s. 297: podane imiona zakonne Gerardus à S. Antonio; ADP, A 41, s. 21: członek konwentu w Oborach w 1699. Święcenia prezbiteratu otrzymał 14 marca 1699 w katedrze w Chełmży z rąk sufragana chełmińskiego Tomasza Skotnickiego.

${ }^{559}$ AKKr 174/614, s. 35; Kart. 27, s. 408; AKKr 175/547, s. 171; Zak. 66; Zak. 61, s. 85. 
Gerardus à S. Joanne RP, Przyborowski Joannes ${ }^{560}$, nat. 27.06.1758, prof. 06.11.1774 Posnaniae, in provinciae Minoris Poloniae.

Gerardus à S. Josepho Fr, Wagner Josephus ${ }^{561}$, sartor, nat. 09.02.1726, prof. 12.09.1773 Gedani, obit. 30.11.1788 Varsaviae.

Gerardus à S. Simone RP, Piotrowski Simon ${ }^{562}$, ex professor rhetorices et philosophiae, nat. 01.11.1733, prof. 22.09.1757 Gedani, presb. 02.07.1761 Posnaniae, obit. 11.08.1797 Bidgostiae.

Gerardus Zdunkiewicz $\mathrm{Fr}^{563}$, organarius, choralis, emeritus, nat. 1792, prof. 1820, obit. 22.04.1865 Oboriis.

Gervasius à S. Antonio Trzciński RP ${ }^{564}$, nat. 1704, prof. 1723, obit. 11.06.1742 Oboriis.

Gervasius à S. Bartholomeo Fr, Skibinski Petrus ${ }^{565}$, nat. 1726, prof. 06.06.1746 Posnaniae, obit. 14.06.1784 Kcynae.

Gervasius à S. Dominico ARP, Fankydeyski Dominicus ${ }^{566}$, ex prior loci, actualis definitor provinciae, nat. 06.08.1757, prof. 16.10.1777 Gedani, presb. 08.10.1780 Posnaniae, obit. 20.05.1802 Plonscii.

Gervasius à S. Marcellino $\mathrm{RP}^{567}$, subprior, nat. 1672, prof. 1690, obit. 18.06.1709 Posnaniae.

Godefridus à S. Jacobo ARP, Styller Jacobus ${ }^{568}$, STL, ex prior Bidgostiensis, ex definitor ac secretarius provinciae, musicus, nat. 03.01.1732, prof. 13.01.1756 Posnaniae, presb. 26.07.1760 Posnaniae, obit. 09.03.1807 Kcynae.

Godefridus à S. Stanislao $\mathrm{Fr}^{569}$, nat. 1640, prof. 1662, obit. 26.02.1682 Oboriis.

Godefridus à S. Thoma $\mathrm{Fr}^{570}$, nat. 1644, prof. 1664, obit. 14.04.1704 Oboriis.

Gratianus à S. Bernardo RP, Krzeminski Bernardus ${ }^{571}$, nat. 24.08.1761, prof. 19.08.1786 Posnaniae, presb. 1789 Gedani.

${ }^{560}$ AKKr 174/614, s. 14-15; ADWł, ABSWł 10, s. 65: święcenia subdiakonatu otrzymał 15 marca 1778 we Włocławku z rąk sufragana włocławskiego Jana Dembowskiego.

${ }^{561}$ AKKr 174/614, s. 26-27; AKKr 175/547, s. 673; Zak. 66; Zak. 61, s. 326.

${ }^{562}$ AKKr 174/614, s. 6-7; AKKr 175/547, s. 455 i 469: podane daty zgonu 14 i 21 sierpnia 1797; Zak. 66; Mańkowski, Liber mortuorum, s. 118: podana data zgonu 14 sierpnia 1797; ADP, C 54a, s. 29: członek konwentu w Gdańsku w 1758. Tonsurę i niższe święcenia otrzymał 11 czerwca 1758 w Kartuzach z rąk sufragana chełmińskiego Franciszka Fabiana Pląskowskiego. Konfrater cystersów koronowskich.

${ }^{563}$ AKKr 175/547, s. 225.

${ }^{564}$ AKKr 174/614, s. 31; AKKr 175/547, s. 325; Zak. 66; Zak. 61, s. 162; AAG, ACap B 79, s. 52 i 53: członek konwentu w Kcyni w latach 1727-1728. Święcenia diakonatu otrzymał 22 grudnia 1727 i prezbiteratu 11 stycznia 1728 w kaplicy seminaryjnej w Gnieźnie z rąk sufragana gnieźnieńskiego Franciszka Kraszkowskiego.

${ }^{565} \mathrm{AKKr}$ 174/614, s. 22-23: podana data zgonu 5 czerwca 1784; AKKr 175/547, s. 331; Zak. 61, s. 166: podana data zgonu 15 czerwca 1784.

${ }^{566} \mathrm{AKKr}$ 174/614, s. 14-15; AKKr 175/547, s. 281; Zak. 66; Zak. 61, s. 141: podana data zgonu 21 maja 1802.

${ }^{567}$ AKKr 175/547, s. 341; Zak. 66; Zak. 61, s. 170: podana data zgonu 19 czerwca 1709.

${ }^{568}$ AKKr 174/614, s. 6-7; AKKr 175/547, s. 137; Zak. 66: podana data zgonu 10 marca 1807 w Bydgoszczy; Zak. 61, s. 68 .

${ }^{569}$ AKKr 175/547, s. 113; Zak. 66; Zak. 61, s. 57: podana data zgonu 26 lutego 1687.

${ }^{570}$ AKKr 175/547, s. 75; Zak. 66; Zak. 61, s. 104.

${ }^{571}$ AKKr 174/614, s. 18-19. 
Gregorius à S. Angelo RP, Chlebowski Martinus ${ }^{572}$, concionator Polonorum Varsaviensis et Kcynensis, nat. 17.09.1716, prof. 20.05.1739, presb. 1742, obit. 01.02.1753 Kcynae.

Gregorius à S. Jacobo ARP, Woycziechowski Jacobus ${ }^{573}$, ex prior Kcynensis, Plonscensis et Klodaviensis, definitor provinciae, nat. 25.07.1672, prof. 04.12.1695, obit. 29.04.1750 Trutoviae.

Gregorius à S. Jacobo RP, Jankowski Jacobus ${ }^{574}$, nat. 03.08.1755, prof. 10.03.1772 Gedani, presb. 04.04.1779 Varsaviae, penit.

Gregorius à S. Mathaeo RP ${ }^{575}$, nat. 1673, prof. 1693, obit. 19.04.1734 Oboriis.

Gregorius à S. Michaele ARP. Moliszewicz (Malisiewicz) Michael ${ }^{576}$, actualis prior poci, nat. 28.09.1738, prof. 01.03.1756 Posnaniae, presb. 19.03.1762 Kcynae, obit. 13.10.1809 Trutoviae.

Gualbertus à S. Casimiro RP, Bauch Casimirus ${ }^{577}$, subprior loci, nat. 01.03.1741, prof. 15.07.1763 Posnaniae, presb. 08.06.1767 Gedani, obit. 30.01.1816 Oboriis.

Guilielmus à S. Christophoro RP, Pierzkatowski Christophorus ${ }^{578}$, nat. 18.02.1753, prof. 26.10.1773 Gedani, presb. 1776 Klodaviae, in provincia Russiae, saecularis.

Guilielmus à S. Philippo RP ${ }^{579}$, concionator Germanorum, procurator, nat. 1741, prof. 1759, presb. 1764, obit. 22.05.1772 Gedani.

Henricus à S. Andrea $\mathrm{Fr}^{580}$, clericus, studens philosophiae, nat. 1714, prof. 1736, obit. 07.05.1737 Gedani.

${ }^{572}$ AKKr 174/614, s. 33; Kart. 27, s. 412; AKKr 175/547, s. 75; Zak. 66; Zak. 61, s. 32; ADP, A 16, s. 70 i 71: członek konwentu w Bydgoszczy w 1740. Święcenia subdiakonatu otrzymał 21 września 1740 i diakonatu 24 września 1740 w Chełmży z rąk sufragana chełmińskiego Macieja Aleksandra Sołtyka.

${ }^{573}$ AKKr 174/614, s. 32: podana data zgonu 29 marca 1750; Kart. 27, s. 407; AKKr 175/547, s. 239; Zak. 66; Zak. 61, s. 119; ADP, A 41, s. 17, 18v i 22: święcenie prezbiteratu przekreślone. Członek konwentu w Bydgoszczy w latach 1697-1698. Święcenia subdiakonatu otrzymał 1 czerwca 1697, diakonatu 21 grudnia 1697 i prezbiteratu 15 marca 1698 w katedrze w Chełmży z rąk sufragana chełmińskiego Tomasza Skotnickiego.

${ }^{574}$ AKKr 174/614, s. 12-13.

${ }^{575}$ AKKr 175/547, s. 219; Zak. 66; Zak. 61, s. 109.

${ }^{576}$ AKKr 174/614, s. 6-7; AKKr 175/547, s. 577; Zak. 66; Zak. 61, s. 278; ADWł, ABSWł 10, s. 13: syn Franciszka. Członek konwentu w Bydgoszczy w 1761. Święcenia diakonatu otrzymał 28 października 1761 w kościele klarysek w Bydgoszczy z rąk sufragana włocławskiego Jana Dembowskiego; AAG, ACon G II 4, s. 91v: podane imiona Franciscus Gregorius à S. Michaele. Święcenia subdiakonatu otrzymał 6 marca 1762 w kolegiacie Św. Jerzego w Gnieźnie z rąk sufragana gnieźnieńskiego Krzysztofa Dobińskiego.

${ }^{577}$ AKKr 174/614, s. 8-9; AKKr 175/547, s. 59; Zak. 66.

${ }^{578} \mathrm{AKKr} 174 / 614$, s. $14-15$.

${ }^{579}$ AKKr 174/614, s. 38; AKKr 175/547 s. 285; Zak. 66; Zak. 61, s. 142; Zakonnicy, s. 335; ADWł, ABSWł 10, s. 12: członek konwentu w Bydgoszczy w 1761. Tonsurę i niższe święcenia otrzymał 28 października 1761 w kościele klarysek w Bydgoszczy z rąk sufragana włocławskiego Jana Dembowskiego; Kroniczka, s. 69 i 194: przybył do rezydencji przy kościele Najświętszej Krwi Pana Jezusa w Poznaniu w maju 1766 z klasztoru Bożego Ciała.

${ }^{580}$ AKKr 175/547 s. 255; Zak. 66; Zak. 61, s. 84 i 127: podana druga data zgonu 25 marca 1737; Zakonnicy, s. 334. 
Henricus à S. Antonio RP, Goldau Antonius ${ }^{581}$, concionator Germanorum, nat. 24.08.1760, prof. 12.07.1777 Gedani, presb. 20.09.1783 Varsaviae, obit. 02.12.1798 Plonscii.

Henricus à S. Christiano RP ${ }^{582}$, obit. 12.12.1718 Kcynae.

Henricus à S. Joanne RP, Miklajewicz Joannes ${ }^{583}$, subprior loci, organarius, nat. 17.09.1717, prof. 01.07.1740, obit. 07.04.1771 Bidgostiae.

Henricus à S. Mathia Fr, Czaplicki Mathias ${ }^{584}$, terminarius, olim quaestuarius bene commendatus, nat. 25.02.1713, prof. 06.07.1758 Gedani, obit. 10.04.1796 Trutoviae.

Henricus à S. Michaele $\rightarrow$ Henricus à S. Mathia

Henricus $\mathrm{Fr}^{585}$, obit. 05.03.1833 Plonscii.

Hieremias à SS. Petro \& Paulo $\mathrm{Fr}^{586}$, nat. 1712, prof. 1740, obit. 27.09.1747 Kcynae.

Hieronymus à S. Antonio RP ${ }^{587}$, nat. 1691, prof. 1712, obit. 31.10.1731 Kcynae.

Hieronymus à S. Crescentio $\mathrm{RP}^{588}$, subprior loci, nat. 1669, prof. 1691, obit. 17.02.1707 Oboriis.

Hieronymus à S. Ignatio $\mathrm{Fr}^{589}$, clericus, nat. 1716, prof. 1733, obit. 01.05.1736 Oboriis.

Hieronymus à S. Michaele ARP, Tomaczykowski Albertus ${ }^{590}$, concionator Polonorum, ex prior Drohobicensis, magister novitiorum prope 9 annis, nat. 22.04.1722, prof. 24.09.1744 Posnaniae, presb. 26.12.1749 Varsaviae, obit. 08.11.1786 Posnaniae.

Hieronymus à S. Michaele Fr, Furga Michael ${ }^{591}$, nat. 03.10.1728, prof. 06.11.1764 Posnaniae, obit. 10.04.1786 Kcynae.

Hieronymus à S. Michaele Fr, Pracki Michael ${ }^{592}$, nat. 27.09.1750, prof. 19.01.1784 Posnaniae, obit. 04.01.1819 Kcynae.

Hieronymus à S. Valentino RP, Pruszkowski Valentinus ${ }^{593}$, seniculus, nat. 14.02.1685, prof. 08.06.1708, obit. 20.11.1755 Markovicae.

${ }^{581}$ AKKr 174/614, s. 14-15; Zak. 66.

${ }^{582}$ Zak. 61, s. 337.

${ }^{583}$ AKKr 174/614, s. 37; Kart. 27, s. 413; AKKr 175/547 s. 195; Zak. 66; Zak. 61, s. 97; A. Mańkowski, Liber mortuorum ..., s. 58: konfrater cystersów koronowskich; Kroniczka, s. 75, 90, 106, 115, 122, 146, 157-158, 161, 165 i 194: podprzeor w klasztorze Bożego Ciała w Poznaniu w latach 1766-1767. Przebywał w rezydencji przy kościele Najświętszej Krwi Pana Jezusa w Poznaniu w latach 1768-1769. Odszedł w maju 1769 na podprzeora w Bydgoszczy.

${ }^{584} \mathrm{AKKr}$ 174/614, s. 24-25: podane imiona zakonne Henricus à S. Michaele; AKKr 175/547 s. 201; Zak. 66: podana data zgonu 13 kwietnia 1796; Zak. 61, s. 75: podana data zgonu 16 marca 1796.

${ }^{585}$ AKKr 175/547, s. 129.

${ }^{586}$ AKKr 175/547, s. 545; Zak. 66; Zak. 61, s. 263: podana data zgonu 28 września 1747.

${ }^{587}$ AKKr 175/547 s. 613; Zak. 66; Zak. 61, s. 296.

${ }^{588}$ AKKr 175/547 s. 95; Zak. 66; Zak. 61, s. 47: podana data zgonu 16 lutego 1707 Bydgoszcz.

${ }^{589}$ AKKr 175/547 s. 243; Zak. 66; Zak. 61, s. 121.

${ }^{590}$ AKKr 174/614, s. 4-5; AKKr 175/547, s. 629; Zak. 66: podana data zgonu 9 listopada 1786; Zak. 61, s. 304.

${ }^{591}$ AKKr 174/614, s. 24-25; Zak. 66; Zak. 61, s. 130.

${ }^{592}$ AKKr 174/614, s. 26-27; Zak. 66; AKKr 175/547, s. 7 i 99: drugi zapis zgonu 19 lutego 1819.

${ }^{593}$ AKKr 174/614, s. 33: podana data zgonu 30 kwietnia 1755; Kart. 27, s. 408; AKKr 175/547, s. 653; Zak. 66; Zak. 61, s. 122 i 318: podane daty zgonu 2 maja 1755 i 22 listopada 1755. 
Hilarion à Puero Jesu RP ${ }^{594}$, nat. 1634, prof. 1656, obit. 25.10.1684 Bidgostiae.

Hilarion à S. Antonio RP, Zochowski Antonius ${ }^{595}$, nat. 16.06.1770.

Hilarion à S. Michaele RP, Krykont Michael ${ }^{596}$, nat. 03.10.1747, prof. 27.09.1768 Gedani, presb. 08.12.1772 Varsaviae, obit. 31.07.1782 Kcynae.

Hilarion à S. Stanislao RP, Zelewski Stanislaus ${ }^{597}$, nat. 05.12.1706, prof. 09.10.1727, obit. 15.04.1767 Trutoviae.

Hilarius à S. Ignatio RP, Ladach Ignatius ${ }^{598}$, nat. 06.04.1773, prof. 30.04.1789 Gedani.

Hilarius à S. Joannes Baptista $\mathrm{Fr}^{599}$, nat. 1632, prof. 1654, obit. 24.11.1686 Posnaniae.

Honoratus à Dulcissimo Nomine JESU RP ${ }^{600}$, nat. 1711, prof. 1735, obit. 26.01.1737 Posnaniae.

Honorius à S. Petro RP, Nowicki Petrus ${ }^{601}$, nat. 28.06.1773.

Hyacinthus à Jezu Maria RP ${ }^{602}$, nat. 1680, prof. 1698, obit. 08.06.1710 Bidgostiae.

Hyacinthus à S. Ignatio Fr, Sadkowski Ignatius ${ }^{603}$, nat. 02.08.1713, prof. 10.08.1758 Gedani, obit 26.02.1777 Trutoviae.

Hyacinthus à S. Ignatio RP ${ }^{604}$, concionator Polonorum, nat. 1702, prof. 1719, obit. 19.07.1744 Plonscii.

Hyacinthus à S. Jacobo RP, Krzyzanowski Jacobus ${ }^{605}$, nat. 22.07.1747, prof. 1768 Gedani, presb. 06.06.1773 Varsaviae.

Hyacinthus à S. Michaele Fr, Lewkowski Michael ${ }^{606}$, nat. 24.09.1752, prof. 09.09.1778 Posnaniae, obit. 12.10.1794 Markovicae.

${ }^{594}$ AKKr 175/547, s. 601; Zak. 66; Zak. 61, s. 282: podana data zgonu 17 października 1684.

${ }^{595}$ AKKr 174/614, s. 20; ADP, C 54a, s. 154 i 155: członek konwentu w Gdańsku w latach 17931794. Święcenia subdiakonatu otrzymał 3 grudnia 1793 w kościele karmelitów w Gdańsku i diakonatu 14 maja 1794 w Oliwie z rąk sufragana chełmińskiego Iwona Onufrego Rogowskiego.

${ }^{596}$ AKKr 174/614, s. 10-11 i 42; AKKr 175/547, s. 427; Zak. 66; Zak. 61, s. 212; ADP, C 54a, s. 84 i 85: członek konwentu w Bydgoszczy w 1772. Tonsurę i niższe święcenia otrzymał 2 sierpnia 1772, święcenia subdiakonatu 10 sierpnia 1772, diakonatu 16 sierpnia 1772 i prezbiteratu 23 sierpnia 1772 w Chełmży. Szafarzem wszystkich święceń był sufragan chełmiński Franciszek Fabian Pląskowski.

${ }^{597}$ AKKr 174/614, s. 37: podana data zgonu 16 kwietnia 1767; Kart. 27, s. 410; AKKr 175/547, s. 211; Zak. 66; Zak. 61, s. 105.

${ }^{598}$ AKKr 174/614, s. 18-19.

${ }^{599}$ AKKr 175/547, s. 661; Zak. 66; Zak. 61, s. 321: podana data zgonu 25 listopada 1686.

${ }^{600} \mathrm{AKKr}$ 175/547, s. 51; Zak. 66; Zak. 61, s. 26.

${ }^{601}$ AKKr 174/614, s. 20.

${ }^{602}$ AKKr 175/547, s. 319; Zak. 66; Zak. 61, s. 159: podane miejsce zgonu Rynarzewo.

${ }^{603}$ AKKr 174/614, s. 24-25 i 39; Zak. 66; AKKr 175/547, s. 111: podana data zgonu 25 lutego 1777; Zak. 61, s. 57.

${ }^{604}$ AKKr 174/614, s. 31; AKKr 175/547, s. 405; Zak. 66; Zak. 61, s. 200; AAG, ACap B 79, s. 54v: członek konwentu w Poznaniu w 1728. Święcenia przebiteratu otrzymał 7 marca 1728 w katedrze w Gnieźnie z rąk sufragana gnieźnieńskiego Franciszka Kraszkowskiego.

${ }^{605}$ AKKr 174/614, s. 10-11.

${ }^{606}$ AKKr 174/614, s. 26-27; AKKr 175/547, s. 575; Zak. 61, s. 277. 
Hyacinthus à S. Paulo RP, Zielinski Paulus ${ }^{607}$, ex concionator Polonorum, nat. 29.06.1688, prof. 15.09.1715, obit. 23.11.1766 Oboriis.

Hyacinthus ab Assumptione B.M.V. $\mathrm{Fr}^{608}$, nat. 1658, prof. 1680, obit. 12.09.1709 Posnaniae.

Hyacinthus Nagalski Fr ${ }^{609}$, obit. 30.06.1852 Wąsosiae.

Hyppolitus à S. Alberto Fr, Sieroinski Andreas ${ }^{610}$, oeconomus, nat. 25.11.1687, prof. 13.08.1711, obit. 03.03.1755 Drohobiciis.

Hyppolitus à S. Laurentio $\mathrm{Fr}^{611}$, clericus, nat. 1685, prof. 1704, obit.13.08.1708 Posnaniae.

Hyppolitus à S. Michaele Fr, Assmann (Hassmann) Michael $^{612}$, nat. 14.07.1751, prof. 27.08.1780 Posnaniae, obit. 12.02.1807 Gedani.

Hyppolitus à S. Paulo $\rightarrow$ Hyppolitus à SS. Petro \& Paulo

Hyppolitus à SS. Petro \& Paulo Fr, Karnowski Paulus ${ }^{613}$, nat. 16.12.1726, prof. 15.12.1759 Posnaniae, obit. 05.01.1803 Markovicae.

Ignatius à Purificat B.M. V. Fr, Solecki Mathias ${ }^{614}$, pictor et terminarius bene meritus, nat. 26.02.1717, prof. 02.02.1739 Posnaniae, obit. 05.11.1776 Kcynae.

Ignatius à S. Antonio RP, Gerhman Antonius ${ }^{615}$, cantor choralis eximius, nat. 30.04.1753, prof. 24.02.1774 Gedani, presb. 25.06.1777 Gedani, obit. 27.03.1804 Gedani.

Ignatius à S. Blasio $\mathrm{Fr}^{616}$, nat. 1675, prof. 1696, obit. 17.08.1709 Posnaniae.

Ignatius à S. Josepho $\mathrm{ARP}^{617}$, primus vicarius provincialis Carmelitarum Reformatorum in Polonia, obit. 23.03.1689 Posnaniae.

Ignatius à S. Paulo $\mathrm{Fr}^{618}$, novitius, 28.07.1709 Posnaniae.

Ignatius à S. Vladislao RP ${ }^{619}$, nat. 1645, prof. 1665, obit. 06.01.1694 Posnaniae.

Ildephonsus à S. Francisca RP ${ }^{620}$, nat. 1639, prof. 1658, obit. 02.03.1702 Posnaniae.

${ }^{607}$ AKKr 174/614, s. 36; Kart. 27, s. 408; AKKr 175/547, s. 659; Zak. 66; Zak. 61, s. 320 i 324: podana data zgonu 24 listopada 1766, a zapis z datą 28 listopada 1766 przekreślony.

${ }^{608} \mathrm{AKKr}$ 175/547, s. 515; Zak. 66; Zak. 61, s. 241 i 242: podane daty zgonu 6 września 1709 i 7 września 1709 Święcichowicach.

${ }^{609}$ Zak. 66.

${ }^{610}$ AKKr 174/614, s. 33; Kart. 27, s. 414; AKKr 175/547, s. 125; Zak. 66; Zak. 61, s. 62.

${ }^{611}$ AKKr 175/547, s. 453; Zak. 66; Zak. 61, s. 203: podana data zgonu 22 lipca 1709.

${ }^{612}$ AKKr 174/614, s. 26-27; Zak. 66; AKKr 175/547, s. 107: podana data zgonu 23 lutego 1806; Zak. 61, s. 43; Zakonnicy, s. 336: podany tylko rok zgonu i nazwisko Assmann.

${ }^{613}$ AKKr 174/614, s. 24-25; AKKr 175/547, s. 9; Zak. 66; Zak. 61, s. 4: podana data zgonu 4 stycznia 1803.

${ }^{614}$ AKKr 174/614, s. 22-23 i 39; Kart. 27, s. 415; AKKr 175/547, s. 623; Zak. 66: podana data zgonu 9 listopada 1776; Zak. 61, s. 301.

${ }^{615}$ AKKr 174/614, s. 14-15; AKKr 175/547, s. 173; Zak. 66; Zak. 61, s. 86; Zakonnicy, s. 336; ADP, C 54a, s. 125 i 126: członek konwentu w Gdańsku w latach 1775-1776. Tonsurę i niższe święcenia otrzymał 30 lipca 1775 w kościele św. Wojciecha pod Gdańskiem, subdiakonatu 2 marca 1776 w kościele karmelitów w Gdańsku i diakonatu 23 marca 1776 w kościele św. Wojciecha pod Gdańskiem z rąk sufragana chełmińskiego Franciszka Fabiana Pląskowskiego.

${ }^{616}$ AKKr 175/547, s. 461; Zak. 66.

${ }^{617}$ AKKr 175/547, s. 165; Zak. 66; Zak. 61, s. 82.

${ }^{618}$ Zak. 61, s. 209.

${ }^{619}$ AKKr 175/547, s. 11; Zak. 66; Zak. 61, s. 6: brak roku zgonu.

${ }^{620} \mathrm{AKKr}$ 175/547, s. 123; Zak. 66; Zak. 61, s. 61. 
Ildephonsus à S. Martino RP, Kowalski Martinus ${ }^{621}$, dispositus pro studio theologico Varsaviam, nat. 08.11.1750, prof. 26.11.1770 Posnaniae, presb. 26.12.1773 Gedani, obit. 09.08.1775 Varsaviae.

Ildephonsus à S. Paulo RP, Wolff Paulus ${ }^{622}$, actualis concionator Polonorum Posnaniensis, nat. 13.03.1763, prof. 16.07.1781 Gedani, presb. 12.07.1787 Posnaniae, obit. 06.03.1796 sub manu medici Thorunii, sepultus in ecclesia parochiali.

Ildephonsus à S. Spiritu RP ${ }^{623}$, nat. 1707, prof. 1729, obit. 07.07.1741 Klodaviae.

Innocentius à S. Adalberto Berkowski RP ${ }^{624}$, concionator emeritus ac laudabilis, subprior Trutoviensis, nat. 1794, prof. 1817, presb. 1819, obit. 02.10.1839 Wąsosiae.

Innocentius à S. Christiano RP, Betkier Christianus ${ }^{625}$, concionator Polonorum, nat. 11.03.1758, prof. 03.08.1775 Gedani, presb. 12.03.1776 Varsaviae, obit. 22.05.1796 Klodaviae.

Innocentius à S. Philippo Fr, Rzepecki Philippus ${ }^{626}$, terminarius, sartor, nat. 01.05.1732, prof. 06.07.1756 Posnaniae, obit. 30.12.1797 Posnaniae.

Innocentius à Visitatione B.M.V. RP, Durowicz Laurentius ${ }^{627}$, variis in conventibus sacrista; hora vero 11 ante mediam noctem, vitae suae ultimum terminavit periodum in capella Sanguinis Christi, nat. 21.08.1705, prof. 06.07.1730, presb. 1731, obit. 09.01.1762 Posnaniae.

Isaac à S. Jacobo Fr, Radwenski Josephus ${ }^{628}$, nat. 17.06.1733, prof. 03.12.1755 Gedani, migravit nescio quo.

Isidorus à S. Antonio à Fulmine RP ${ }^{629}$, procurator, nat. 1728, prof. 1746, obit. 24.06.1760 Kcynae.

Isidorus à S. Constantino RP, Schreiber Constantinus ${ }^{630}$, sacrista, nat. 18.09.1704, prof. 05.02.1730, obit. 27.08.1768 Trutoviae.

Isidorus à S. Luca $\mathrm{Fr}^{631}$, nat. 1650, prof. 1672, obit. 01.10.1690 Oboriis.

${ }^{621}$ AKKr 174/614, s. 12-13 i 39; AKKr 175/547, s. 445; Zak. 66; Zak. 61, s. 220: podana data zgonu 8 sierpnia 1775; ADP, C 54a, s. 86 i 87: członek konwentu w Oborach w 1773. Tonsurę i niższe święcenia otrzymał 21 marca 1773, święcenia subdiakonatu 27 marca 1773 i diakonatu 1 maja 1773 w Chełmży z rąk sufragana chełmińskiego Franciszka Fabiana Pląskowskiego.

${ }^{622}$ AKKr 174/614, s. 16-17; AKKr 175/547, s. 127: podana data zgonu 4 marca 1796; Zak. 66; Zak. 61, s. 65.

${ }^{623}$ AKKr 175/547, s. 379; Zak. 66; Zak. 61, s. 189: podana data zgonu 8 lipca 1741.

${ }^{624} \mathrm{AKKr}$ 175/547, s. 555; Zak. 66: podana data zgonu 2 września 1839.

${ }^{625}$ AKKr 174/614, s. 14-15; AKKr 175/547 s. 285; Zak. 66; Zak. 61, s. 142.

${ }^{626}$ AKKr 174/614, s. 22-23; AKKr 175/547, s. 733; Zak. 66; Kroniczka, s. 152 i 199: przebywał w rezydencji przy kościele Najświętszej Krwi Pana Jezusa w Poznaniu w 1768.

${ }^{627}$ AKKr 174/614, s. 35; Kart. 27, s. 411; AKKr 175/547, s. 19; Zak. 66; Zak. 61, s. 9 i 10: podany drugi zapis zgonu 10 stycznia 1762; Kroniczka, s. 199: przebywał w klasztorze Bożego Ciała w Poznaniu w 1743.

${ }^{628}$ AKKr 174/614, s. 22-23.

${ }^{629}$ AKKr 174/614, s. 35; AKKr 175/547, s. 351; Zak. 66; Zak. 61, s. 174.

${ }^{630} \mathrm{AKKr} 174 / 614$, s. 37: podana data zgonu 26 sierpnia 1768; Kart. 27, s. 411; AKKr 175/547, s. 483; Zak. 66; Zak. 61, s. 230: podana data zgonu 26 sierpnia 1768; Kroniczka, s. 34 i 191: kapelan domowy w Iłówcu. Przybył do rezydencji przy kościele Najświętszej Krwi Pana Jezusa w Poznaniu w październiku 1763.

${ }^{631}$ AKKr 175/547, s. 553; Zak. 66; Zak. 61, s. 265: podana data zgonu 30 września 1690. 
Isidorus à S. Mathia ARP, Neuman Mathias ${ }^{632}$, ex prior Lipiensis et Kcynensis, ex secretarius provinciae, praesidens loci (in oratorio Sanguinis Christi), nat. 26.02.1758, prof. 10.05.1775 Gedani, presb. 31.03.1781 Posnaniae, obit. 26.04.1819 Posnaniae.

Isidorus à S. Stephano $\mathrm{Fr}^{633}$, nat. 1642, prof. 1665, obit. 25.12.1691 Oboriis.

Ivo à S. Antonio ARP, Bigoszewski Antonius ${ }^{634}$, ex prior Wąsosiae in antiqua observantia provinciae Minoris Poloniae, secretarius eiusdem provinciae. In nostra autem observantia et provincia, ex subprior Lipiensis, subprior loci, nat. 20.03.1724, prof. 21.06.1744 Cracoviae, presb. 13.04.1748 Cracoviae, obit. 26.03.1776 Plonscii.

Ivo à S. Joanne Baptista $\mathrm{ARP}^{635}$, ex lector philosophiae, ex prior Bidgostiensis et Lipiensis, actualis subprior loci, nat. 1729, prof. 1750, presb. 1756, obit. 08.07.1771 Oboriis.

Jacobinus à S. Joanne Fr, Ziemieniecki Joannes ${ }^{636}$, nat. 24.07.1764, prof. 19.08.1786 Posnaniae, obit. 23.05.1817 Varsaviae.

Jacobus à Matre Dei $\mathrm{Fr}^{637}$, nat. 1656, prof. 1682, obit. 29.05.1714 Kcynae.

Jacobus à $S$. Andrea $\rightarrow$ Jacobus à $S$. Anna

Jacobus à S. Anna RP ${ }^{638}$, concionator Polonorum, subprior loci, nat. 1694, prof. 1714, obit. 08.08.1726 Markovicae.

Jacobus à S. Bartholomaeo $\mathrm{Fr}^{639}$, nat. 1640, prof. 1662, obit. 27.01.1682 Gedani.

Jacobus à S. Carolo $\mathrm{Fr}^{640}$, terminarius, nat. 1727, prof. 1765, obit. 26.05.1773 Markovicae.

Jacobus à S. Joanne RP, Knop Joannes ${ }^{641}$, exorcista, nat. 11.06.1741, prof. 05.08.1765 Gedani, presb. 26.06.1768 Gedani, obit. 30.10.1807 Kcynae.

Jacobus à S. Michaele $\mathrm{Fr}^{642}$, nat. 1696, prof. 1717, obit. 07.06.1726 Trutoviae.

Jacobus à S. Paulo $\mathrm{Fr}^{643}$, nat. 1664, prof. 1686, obit. 19.09.1714 Posnaniae.

Jacobus ab Omnibius Sanctis RP, Ruchniewicz Ignatius ${ }^{644}$, nat. 22.06.1710, prof. 03.11.1729, obit. 01.03.1757 Plonscii.

${ }^{632}$ AKKr 174/614, s. 14-15; AKKr 175/547, s. 233; Zak. 66.

${ }^{633}$ AKKr 175/547, s. 723; Zak. 66.

${ }^{634}$ AKKr 174/614, s. 4-5 i 39; AKKr 175/547, s. 171; Zak. 66; Zak. 61, s. 85; Kroniczka, s. 89, 90, 93, 94, 96 i 195: przybył do rezydencji przy kościele Najświętszej Krwi Pana Jezusa w Poznaniu w marcu 1767. W kwietniu tego roku powrócił do konwentu Bożego Ciała w Poznaniu jako wikariusz przeora. W tym samym miesiącu powrócił do rezydencji i w czerwcu został skierowany do klasztoru w Kłodawie.

${ }^{635}$ AKKr 174/614, s. 38: podana data zgonu 8 lipca 1771; AKKr 175/547, s. 383; Zak. 66; Zak. 61, s. 129: podana druga data zgonu 9 maja 1771.

${ }^{636}$ AKKr 174/614, s. 28; AKKr 175/547, s. 287; Zak. 66.

${ }^{637}$ AKKr 175/547, s. 299 i 375; Zak. 66; Zak. 61, s. 149: we wszystkich rękopisach drugi zapis zgonu z datą 5 lipca 1714.

${ }^{638}$ AKKr 175/547, s. 443; Zak. 66; Zak. 61, s. 221: podana data zgonu 9 sierpnia 1726 oraz podane imiona zakonne Jacobus à $S$. Andrea.

${ }^{639}$ AKKr 175/547, s. 53; Zak. 66; Zak. 61, s. 27.

${ }^{640}$ AKKr 174/614, s. 38; AKKr 175/547, s. 293; Zak. 66; Zak. 61, s. 145.

${ }^{641}$ AKKr 174/614, s. 10-11; AKKr 175/547, s. 611; Zak. 66: podana data zgonu 31 października 1807; Zak. 61, s. 295.

${ }^{642}$ AKKr 175/547, s. 317; Zak. 66; Zak. 61, s. 119 i 158: podana druga data zgonu 29 kwietnia 1726.

${ }^{643} \mathrm{AKKr} 175 / 547$, s. 529; Zak. 66; Zak. 61, s. 254.

${ }^{644}$ AKKr 174/614, s. 34; Kart. 27, s. 411; Zak. 61, s. 60. 
Jacobus Lyszkiewicz $\mathrm{Fr}^{645}$, terminarius, nat. 1762, prof. 1791, obit. 13.11.1816 Posnaniae.

Jeremias à S. Norberto $\mathrm{Fr}^{646}$, obit. 30.04.1739 Klodaviae.

Jeremias à SS. Petro \& Paulo Fr, Zalewski Laurentius ${ }^{647}$, nat. 10.08.1712, prof. 01.07.1740, obit. 16.09.1747 Kcynae.

Joachimus à S. Francisco ARP, German Franciscus ${ }^{648}$, STL, ex provincialis, ex definitor, ex prior Trutoviensis et Posnaniensis, nat. 17.07.1722, prof. 01.07.1740 Posnaniae, presb. 25.08.1745 Posnaniae, obit. 06.01.1806 Posnaniae.

Joachimus à S. Georgio Fr, Reich Georgius ${ }^{649}$, seniculus, sartor et hortulanus, nat. 13.07.1698, prof. 19.03.1731, obit. 08.02.1752 Posnaniae.

Joachimus à S. Josepho $\mathrm{RP}^{650}$, STL iubilatus, poeta, orator, concionator, philosophus, theologus praestantissimus, orator famossimus et interpres doctoris, singulari devotionis affectu praeditus, nat. 1686, prof. 1708, obit. 01.04.1739 Posnaniae.

Joachimus à S. Valentino Fr, Krauz Valentinus ${ }^{651}$, nat. 21.02.1731, prof. 23.07.1753 Posnaniae, obit. 22.01.1811 Oboriis.

${ }^{645} \mathrm{AKKr} 175 / 547$, s. 639; Zak. 66.

${ }^{646}$ Zak. 61, s. 120.

${ }^{647}$ AKKr 174/614, s. 31; Kart. 27, s. 415.

${ }^{648}$ AKKr 174/614, s. 2-3; Kart. 27, s. 413; AKKr 175/547, s. 11; Zak. 66: podana data zgonu 8 stycznia 1806; Zak. 61, s. 7: podana data zgonu 7 stycznia 1806; Biogram: SPTK, T. 2, s. 213, W. Murawiec, Joachim od św. Franciszka (2 pot. XVIII w.), karmelita bosy, autor traktatu o aniołach. O. Murawiec błędnie zaliczył go do karmelitów bosych. Należał on do wielkopolskiej prowincji karmelitów trzewiczkowych. Do prowincji tej należał również klasztor w Trutowie, gdzie był przełożonym; Kroniczka, s. 26, 164, 185 i 190: z klasztoru w Gdańsku został skierowany w 1751 do klasztoru Bożego Ciała w Poznaniu na profesora retoryki. Przebywał w tym klasztorze w 1760. Prezydent rezydencji przy kościele Najświętszej Krwi Pana Jezusa w Poznaniu w 1761. Następnie nauczyciel w szkole kanoników regularnych laterańskich w Czerwińsku. Przeor klasztoru w Trutowie w 1767 i w klasztorze Bożego Ciała w Poznaniu od maja 1769. Prowincjał w 1779; A. Mańkowski, Dzieje drukarstwa i piśmiennictwa polskiego w Prusiech Zachodnich wraz z szczegółowa bibliografia druków polskich zachodniopruskich, [w:] „Rocznik Towarzystwa Naukowego w Turuniu”, r. 18: 1911, s. 148-14: autor kazania: Apparencye śmiertelne i nieśmiertelne przy wspaniałym pogrzebie JWJMP Zygmunta Kretkowskiego Woiewody Chetmińskiego, Kowalewskiego, Duninowskiego Starosty orderu białego Orła Kawalera w kościele Gdańskim OO. Karmelitów sciśleyszey Obserwancyi prowincyi $W$. polskiey przed licznym J. O. WW gości kongressem kazaniem żałobnym pokazane przez X. Joachima od S. Franciszka Karmelite teyże Obser. y prow. S teol. Lektora jubilata Przeora konwentu Trutowskiego r. p. 1767 d. 12. Sierpnia. W Gdańsku Typis Joh. Fridr. Bartels. Fol. Str. 30 .

${ }^{649}$ AKKr 174/614, s. 32; Kart. 27, s. 415; AKKr 175/547, s. 77; Zak. 66; Zak. 61, s. 39: brak roku zgonu.

${ }^{650}$ AKKr 175/547, s. 183; Zak. 66; Zak. 61, s. 91; ADP, A 41, s. 27: członek konwentu w Gdańsku w 1707. Tonsurę i niższe święcenia otrzymał 24 września 1707 w katedrze w Chełmży z rąk sufragana chełmińskiego Seweryna Szczuki; Kroniczka, s. 19 i 189: przebywał w klasztorze Bożego Ciała w Poznaniu w 1724, 1733 i 1735. Rezydent w rezydencji przy kościele Najświętszej Krwi Pana Jezusa w Poznaniu w 1733.

${ }^{651}$ AKKr 174/614, s. 22-23; AKKr 175/547, s. 43 i 45: drugi zapis zgonu 23 stycznia 1811. 
Joachimus Kwoka RP ${ }^{652}$, sacerdos Provinciae Austriacae, ad conventum Leopoliensem translatus, per plures annos procurator eiusdem, nat. 1863, prof. 1889, presb. 1895, obit. 12.10.1933 Leopoli.

Joannes à Matre Dolorosa $\mathrm{Fr}^{653}$, nat. 1657, prof. 1682, obit. 25.06.1706 Oboriis.

Joannes à S. Adamo Fr, Brochocki Adamus ${ }^{64}$, nat. 13.08.1750, prof. 29.08.1768 Posnaniae, clericus perpetuus, dispensatus et mortuus.

Joannes à S. Avertano RP ${ }^{655}$, nat. 1651, prof. 1670, obit. 14.07.1710 Bidgostiae.

Joannes à S. Clemento ARP, Kunigk Joannes ${ }^{656}$, STL, ex provincialis, septennalis prior loci; sub eius regimine, in utraque area nostra exstructa sunt quaedam aedificia, in ecclesia chorus ad organa, sacristia cum sepulchro fratrum; eius activitate comparata sunt sex candelabra argentea ac tabernaculum in majori altari, nat. 29.05.1695, prof. 11.11.1714, obit. 25.09.1750 Gedani.

Joannes à S. Cruce à S. Francisco RP Murzynowski Josephus ${ }^{657}$, in saeculo notarius terrestris Terrae Dobrinensis; in religione plenipotens provinciae, pro singulis conventibus, exactissima omnium documentorum summaria compilavit, nat. 1716, prof. 1757 , obit. 19.04.1771 Oboriis.

Joannes à S. Cruce Ficzkiewicz $\mathrm{Fr}^{658}$, subdiaconus, nat. 1782, prof. 1802, obit. 06.08.1831 Guloviae.

Joannes à S. Cruce RP ${ }^{659}$, procurator, syndicus, nat. 1661, prof. 1690, obit. 03.07.1709 Posnaniae.

${ }^{652} \mathrm{AKKr} 175 / 547$, s. 575.

${ }^{653}$ AKKr 175/547, s. 355; Zak. 66; Zak. 61, s. 175: podana data zgonu 24 czerwca 1706.

${ }^{654}$ AKKr 174/614, s. 10-11; A. Boniecki, Herbarz polski, cz. 1: Wiadomości historyczno-genealogiczne o rodach szlacheckich, t. 2, 1900, s. 120: syn Jana stolnika brzezińskiego, chorążego orłowskiego, a następnie chorążego wielkiego łęczyckiego oraz Domicelli Cieńskiej.

${ }^{655}$ AKKr 175/547, s. 393; Zak. 66; Zak. 61, s. 188 i 195: podana druga data zgonu 7 lipca 1709.

${ }^{656}$ AKKr 174/614, s. 32; Kart. 27, s. 408; AKKr 175/547, s. 541; Zak. 66; Zak. 61, s. 260; Zakonnicy, s. 334; Kroniczka, s. 22 i 190; Reszel, Bd.16, H.46, Braunsberg 1906, s. 159 (wpis nr 2059): syn Krzysztofa i Katarzyny. Urodził się 29 maja 1695 w Barczewie na Warmii i tego samego dnia został ochrzczony w tamtejszym kościele parafialnym. Od 1710 kształcił się w gimnazjum jezuickim w Reszlu.

${ }^{657}$ AKKr 174/614, s. 38; AKKr 175/547, s. 219; Zak. 66; Zak. 61, s. 109; Urzędnicy kujawscy i dobrzyńscy XVI-XVIII wieku. Spisy, oprac. K. Mikulski i W. Stanek, Kórnik 1990, s. 182 (wpis 1525): syn Kazimierza. Józef Murzynowski był w latach 1746-1756 pisarzem ziemskim dobrzyńskim. Przeszedł następnie do stanu duchownego; ADWł, ABSWł 10, s. 12: podane imiona Joannes à S. Francisco. Członek konwentu w Bydgoszczy w 1761. Tonsurę i niższe święcenia otrzymał 28 października 1761 w kościele klarysek w Bydgoszczy z rąk sufragana włocławskiego Jana Dembowskiego; AAG, ACon G II 4, s. 91v: podane imiona Joannes à S. Francisco. Święcenia subdiakonatu otrzymał 6 marca 1762 w kolegiacie Św. Jerzego w Gnieźnie z rąk sufragana gnieźnieńskiego Krzysztofa Dobińskiego.

${ }^{658}$ Zak. 66.

${ }^{659}$ AKKr 175/547, s. 371; Zak. 66; Zak. 61, s. 184; ADP, A 41, s. 5, 5v i 6: członek konwentu w Oborach w 1691. Tonsurę i niższe święcenia otrzymał 10 marca 1691, święcenia subdiakonatu 31 marca 1691 w katedrze w Chełmży, diakonatu 14 kwietnia 1691 w kościele parafialnym w Chełmnie i prezbiteratu 9 czerwca 1691 w katedrze w Chełmży. Szafarzem wszystkich święceń był sufragan chełmiński Tomasz Skotnicki. 
Joannes à S. Edvardo RP, Chwastowski Franciscus ${ }^{660}$, nat. 06.10.1711, prof. 16.10.1731 Posnaniae, presb. 06.01.1739 Oboriis, obit. 26.09.1782 Bidgostiae.

Joannes à S. Paulo RP, Chlebowski Paulus ${ }^{661}$, ex concionator Polonorum, nat. 27.01.1772, prof. 1789, presb. 1794, obit. 27.02.1806 Markovicae.

Joannes à S. Samsone RP ${ }^{662}$, nat. 1646, prof. 1665, obit. 13.01.1696 Posnaniae.

Joannes à S. Spiritu $\mathrm{Fr}^{663}$, nat. 1646, prof. 1666, obit. 24.02.1705 Bidgostiae.

Joannes à S. Visitatione B.M.V. Fr $^{664}$, nat. 1646, prof. 1670, obit. 14.05.1700 Oboriis.

Joannes à S. Vladislao ARP, Wolski Vladislaus ${ }^{665}$, STL, jubilatus, ex prior Gedanensis, bis ex provincialis, ex praeses capituli, ex custos provinciae, in lectione librorum assidus, in sacris litteris versatissimus, quare non immerito inter scriptores ecclesiasticos numerandus venit, edidit enim binos tomos, unum: "Trifolium canonico-juridicum", secundum: "Isagoge seu interpretatio S. Scripturae" intitulatos, ac alia plurima scripto reliquit. Vir vere exemplaris et omnibus virtutubis ornatus, nat. 08.07.1703, prof. 23.02.1721, obit. 21.06.1759 Gedani.

Joannes à S.P.N. Elia ARP ${ }^{666}$, ex prior Bidgostiensis, nat. 1650, prof. 1670, obit. 28.05.1686 Oboriis.

Joannes Cantius à $\mathrm{S}$. Ignatio $\rightarrow$ Cantius à S. Ignatio

Joannes Chrysostomus à $S$. Laurentio $\rightarrow$ Chrysostomus à S. Laurentio

Joannes Nepomucenus à Conversione $S$. Pauli $\rightarrow$ Nepomucenus à Conversione $S$. Pauli

Joannes Nepomucenus à S. Casimiro Oczkowski ARP ${ }^{667}$, ex praeses capituli, ex definitor provinciae, ex prior Oboriensis ac pluribus annis Klodaviensis, nat. 1788, prof. 1813, presb. 1816, obit 26.04.1857 Klodaviae.

Josaphat à S. Norberto RP, Polakiewicz Norbertus ${ }^{668}$, STL, nat. 21.05.1733. prof. 09.05.1760 Gedani, presb. 09.05.1762 Gedani, obit. 27.01.1787 Posnaniae, in residentia Sanguinis Christi.

\section{Josephat a S. Adalberto $\rightarrow$ Josaphat à S. Norberto}

${ }^{660} \mathrm{AKKr} 174 / 614$, s. $2-3$ i 42: podana data zgonu 20 września 1782; Kart. 27, s. 411; AKKr 175/547, s. 543; Zak. 66; Zak. 61, s. 261; Mańkowski, Liber mortuorum, s. 81: konfrater cystersów koronowskich; Kroniczka, s. 96, 126, 134 i 196: podane imiona Jan od św. Gerarda. Przybył do rezydencji przy kościele Najświętszej Krwi Pana Jezusa w Poznaniu w czerwcu 1767 z klasztoru w Markowicach. Odszedł do konwentu Bożego Ciała w Poznaniu na własną prośbę w marcu 1768.

${ }^{661}$ AKKr 174/614, s. 20; AKKr 175/547, s. 115; Zak. 66: podana data zgonu 27 stycznia 1806; Zak. 61, s. 58 .

${ }^{662}$ AKKr 175/547, s. 25; Zak. 66; Zak. 61, s. 13: podana data zgonu 13 stycznia 1689.

${ }^{663}$ AKKr 175/547, s. 109; Zak. 66; Zak. 61, s. 55.

${ }^{664}$ AKKr 175/547, s. 269; Zak. 66; Zak. 61, s. 134.

${ }^{665}$ AKKr 174/614, s. 34; Kart. 27, s. 409; AKKr 175/547, s. 349; Zak. 66; Zak. 61, s. 172; Zakonnicy, s. 335; Informacja od Siostry Małgorzaty Borkowskiej, która ukaże się w IV tomie Leksykonu; Borkowska, Leksykon, s. 358; Fankidejski, Utracone kościoły, s. 196: syn Adama i Magdaleny. Jego siostra Konstancja (?-1755) była norbertanką w Żukowie. W 1748 odprawił pierwszą mszę w nowej kaplicy w Niestępowie u Aleksandra Wolskiego.

${ }^{666}$ AKKr 175/547, s. 297; Zak. 66; Zak. 61, s. 148

${ }^{667}$ AKKr 175/547, s. 233; Zak. 66.

${ }^{668}$ AKKr 174/614, s. 8-9; AKKr 175/547, s. 53; Zak. 66; Zak. 61, s. 27; ADWł, ABSWł 10, s. 13 (podane imiona Jozafat od Św. Wojciecha); ADP, C 54a, s. 48: członek konwentu w Gdańsku w latach 1761-1762. Święcenia subdiakonatu otrzymał 28 października $1761 \mathrm{w}$ kościele klarysek w Bydgoszczy z rąk sufragana włocławskiego Jana Dembowskiego. Święcenia diakonatu otrzymał 
Josephus à Jezu Maria $\mathrm{Fr}^{669}$, clericus, nat. 1668, prof. 1684, obit. 17.07.1691 Posnaniae.

Josephus à Puero Jezu Fr ${ }^{670}$, nat. 1645, prof. 1669, obit. 31.01.1690 Posnaniae.

Josephus à S. Adamo Hamerski $\mathrm{Fr}^{671}$, in devotione exiguus, morbo cholerae (grasante eodem anno) raptus vitam finivit, professandus pridie mortis et munitus omnibus moribundorum Sacramentis, nat. 1772, obit. 25.08.1852 Klodaviae.

Josephus à S. Andrea Corsino $\mathrm{Fr}^{672}$, nat. 1646, prof. 1666, obit. 15.01.1703 Posnaniae.

Josephus à S. Anna $\mathrm{Fr}^{673}$, nat. 1645, prof. 1666, obit. 27.01.1680 Posnaniae.

Josephus à S. Antonio $\mathrm{Fr}^{674}$, clericus, nat. 1663, prof. 1681, obit. 20.02.1686 Posnaniae.

Josephus à S. Antonio Fr, Lasota Antonius ${ }^{675}$, organarius, choralis, nat. 1693, prof. 29.02.1716, obit. 09.12.1752 Plonscii.

Josephus à S. Apollonia Fr, Mitkiewicz Josephus ${ }^{676}$, terminarius bene meritus, nat. 10.03.1686, prof. 13.07.1712, obit. 29.12.1758 Drohobiciis.

Josephus à S. Clemente RP ${ }^{677}$, nat. 1674, prof. 1693, obit. 01.07.1709 Posnaniae.

Josephus à S. Disma RP, Trzebicki Victor ${ }^{678}$, nat. 27.02.1740, prof. 16.06.1756 Gedani, presb. 07.08.1763 Markovicae, saecularisatus.

Josephus à S. Ignatio Wolschon $\mathrm{ARP}^{679}$, STL, provincialis reelectus, 10 annis magister novitiorum, ex subprior Oboriensis, ex professor theologiae, orator laudabilis, ex definitor et secretarius provinciae, vir virtutibus plenus et exemplaris, nat. 1796, prof. 1813, presb. 1818, obit. 09.04.1837 Varsaviensis.

Josephus à S. Jacobo $\mathrm{Fr}^{680}$, obit. 06.11.1760 Markovicae.

Josephus à S. Joanne Rożewicz ARP ${ }^{681}$, definitor provinciae, nat. 1771, prof. 1792, presb. 1796, obit. 08.05.1810 Varsaviae.

Josephus à S. Marco $\mathrm{Fr}^{682}$, nat. 1639, prof. 1666, obit. 25.08.1708 Varsaviae.

Josephus à S. Maria $\rightarrow$ Josephus à S. Marco

12 kwietnia 1762 i prezbiteratu 18 kwietnia 1762 w Chełmży z rąk sufragana chełmińskiego Franciszka Fabiana Pląskowskiego.

${ }^{669}$ AKKr 175/547, s. 399; Zak. 66; Zak. 61, s. 198.

${ }^{670}$ AKKr 175/547, s. 61; Zak. 66; Zak. 61, s. 31.

${ }^{671}$ Zak. 66.

${ }^{672}$ AKKr 175/547, s. 29; Zak. 66; Zak. 61, s. 15.

${ }^{673}$ AKKr 175/547, s. 53; Zak. 66; Zak. 61, s. 27.

${ }^{674}$ AKKr 175/547, s. 101; Zak. 66; Zak. 61, s. 51.

${ }^{675}$ Kart. 27, s. 414; AKKr 175/547, s. 691; Zak. 66; Zak. 61, s. 76 i 333: podana data zgonu 17 marca 1752 i 8 grudnia 1752 .

${ }^{676}$ AKKr 174/614, s. 34; Kart. 27, s. 414; AKKr 175/547, s. 731; Zak. 66.

${ }^{677}$ AKKr 175/547, s. 367; Zak. 66; Zak. 61, s. 182.

${ }^{678}$ AKKr 174/614, s. 6-7; ADWł, ABSWł 10, s. 21: święcenia prezbiteratu otrzymał 26 lipca 1763 we Włocławku z rąk sufragana włocławskiego Jana Dembowskiego.

${ }^{679}$ AKKr 175/547, s. 199; Zak. 66.

${ }^{680}$ AKKr 174/614, s. 35.

${ }^{681}$ AKKr 175/547, s. 257; Zak. 66; ADP, C 54a, s. 154: członek konwentu w Gdańsku w 1793. Tonsurę i niższe święcenia otrzymał 3 grudnia 1793 w kościele karmelitów w Gdańsku z rąk sufragana chełmińskiego Iwona Onufrego Rogowskiego.

${ }^{682} \mathrm{AKKr}$ 175/547, s. 479; Zak. 66; Zak. 61, s. 229: podane imiona zakonne Josephus à S. Maria. 
Josephus à S. Maria ARP, Czechowicz Joannes ${ }^{683}$, ex prior Lipiensis et Oboriensis, nat. 19.09.1701, prof. 21.09.1717, obit. 11.02.1759 Trutoviae.

Josephus à S. Martino RP, Tomaszewski Martinus ${ }^{684}$, ex antiqua observatia Leopoli trahens Posnaniam qua diaconus, in nostra strictiori observantia factus sacerdos, post concionator Polonorum Ploncensis, nat. 25.04.1759, prof. 28.05.1778 Leopoli, presb. 19.12.1783 Posnaniae, obit. 01.01.1791 Varsaviae.

Josephus à S. Mathia RP, Woyciechowski Mathias ${ }^{685}$, nat. 25.01.1714, prof. 19.03.1731, obit. 18.06.1754 Oboriis.

Josephus à S. Michaele ARP ${ }^{686}$, ex prior Bidgostiensis, prior loci, nat. 1644, prof. 1663, obit. 10.02.1687 Oboriis.

Josephus à S. Michaele $\mathrm{Fr}^{687}$, nat. 1730, prof. 1751, obit. 06.11.1760 Markovicae.

Josephus à S. Onuphrio Fr, Maszkiewicz Andreas ${ }^{688}$, sartor, nat. 30.11.1743, prof. 05.03.1765 Posnaniae, obit 22.02.1803 Trutoviae.

Josephus à S. Stanislao RP ${ }^{689}$, nat. 1652, prof. 1670, obit. 26.05.1705 Gedani.

Josephus à S.P.N. Elia ARP, Borowski Stanislaus ${ }^{690}$, secretarius provinciae, definitor, quondam prior Oboriensis, quinquies prior Varsaviensis, ubi notabiliter complevit fabricam ecclesiae, quam 5 altaribus eleganti forma aedificatis, praestantissimis imaginibus ac subtilibus sculpturis adornavit, bis primitians, seniculus, nat. 24.09.1684, prof. 16.03.1706, obit. 06.04.1761 Varsaviae.

Josephus à Virgine Maria $\mathrm{Fr}^{691}$, nat. 1645, prof. 1666, obit. 04.12.1687 Gedani.

Josephus Olszewski Fr $^{692}$, quaestiarius, nat. 1764, obit. 07.01.1840 Trutoviae.

Julianus à S. Antonio RP, Sikorski Lucas ${ }^{693}$, oeconomus, nat. 17.10.1703, prof. 08.01.1733, obit. 08.11.1758 Posnaniae.

Julianus à S. Joanne $\mathrm{Fr}^{694}$, diaconus, studens philosophiae, nat. 1740, prof. 1764, obit. 22.04.1767 Gedani.

Julianus à S. Josepho ARP, Klimkowski Josephus ${ }^{695}$, STL, ex definitor provinciae, nat. 11.05.1760, prof. 10.06.1776 Gedani, presb. 14.06.1783 Varsaviae, obit. 03.04.1804 Plonscii.

${ }^{683}$ AKKr 174/614, s. 34; Kart. 27, s. 409; AKKr 175/547, s. 83; Zak. 66; Zak. 61, s. 42.

${ }^{684} \mathrm{AKKr} 174 / 614$, s. 18-19; AKKr 175/547, s. 1 i 47: podana druga data zgonu 24 stycznia 1791.

${ }^{685}$ AKKr 174/614, s. 33: podana data zgonu 16 czerwca 1754; Kart. 27, s. 411; AKKr 175/547, s. 341 ; Zak. 66; Zak. 61, s. 169.

${ }^{686} \mathrm{AKKr}$ 175/547, s. 81; Zak. 66; Zak. 61, s. 42: podana data zgonu 11 lutego 1687.

${ }^{687} \mathrm{AKKr}$ 175/547, s. 625; Zak. 66; Zak. 61, s. 302 i 301: zapis przekreślony.

${ }^{688}$ AKKr 174/614, s. 24-25; AKKr 175/547, s. 101: podana data zgonu 20 lutego 1803; Zak. 66; Zak. 61, s. 53.

${ }^{689}$ AKKr 175/547, s. 293; Zak. 66; Zak. 61, s. 145: podana data zgonu 25 maja 1705.

${ }^{690}$ AKKr 174/614, s. 35; Kart. 27, s. 407, AKKr 175/547, s. 193; Zak. 66; Zak. 61, s. 96.

${ }^{691}$ AKKr 175/547, s. 681; Zak. 66; Zak. 61, s. 330.

${ }^{692}$ AKKr 175/547, s. 13; Zak. 66.

${ }^{693} \mathrm{AKKr} 174 / 614$, s. 34: podana data zgonu 12 maja 1758; Kart. 27, s. 411; AKKr 175/547, s. 629; Zak. 66; Zak. 61, s. 132 i 303: podane daty zgonu 12 maja 1758 i 7 listopada 1758.

${ }^{694}$ AKKr 174/614, s. 37; AKKr 175/547, s. 221; Zak. 66; Zak. 61, s. 110 i 140: zapis z datą zgonu 20 kwietnia 1767 przekreślony oraz podana data zgonu 20 maja 1767; Zakonnicy, s. 335.

${ }^{695}$ AKKr 174/614, s. 14-15; AKKr 175/547, s. 187; Zak. 66: podana data zgonu 2 kwietnia 1804; Zak. 61, s. 90: podana data zgonu 31 marca 1804. 
Julianus ab Epiphania Domini ARP ${ }^{696}$, STL, jubilatus, ex secretarius provinciae, concionator Polonorum, ex prior loci, nat. 1686, prof. 1707, obit. 09.10.1739 Gedani.

Julius à S. Teresia RP, Wolski Nicolaus ${ }^{697}$, nat. 13.11.1711, prof. 24.04.1744, obit. 29.01.1768 Drohobiciis.

Justinianus à S. Mathia Gowarzewski RP ${ }^{698}$, subprior loci, nat. 1674, prof. 1695, obit. 10.09.1710 Bidgostiae.

Justinianus à S. Simone RP, Godlewski Simon ${ }^{699}$, concionator Polonorum, nat. 26.10.1725, prof. 11.09.1746 Posnaniae, presb. 23.04.1753 Posnaniae, obit. 04.04.1793 Varsaviae.

Justinianus à S. Stephano $\mathrm{Fr}^{700}$, clericus, nat. 1703, prof. 1723, obit. 09.04.1725 Kcynae.

Justinus à S. Josepho RP, Chądzynski Josephus ${ }^{701}$, nat. 15.03.1725, prof. 10.12.1743 Posnaniae, presb. 17.05.1750 Kcynae, obit. 24.06.1788 Klodaviae.

Justus à S. Simone ARP, Montewski Simon ${ }^{702}$, ex prior Bidgostiensis, Markovicensis et Kcynensis, ex definitor, concionator, nat. 24.10.1761, prof. 17.09.1781 Gedani, presb. 01.01.1786 Posnaniae, obit. 16.01.1823 Kcynae.

Kilianus à S. Adamo RP, Mez Adamus ${ }^{703}$, subprior loci, nat. 08.09.1742, prof. 30.09.1769 Posnaniae, presb. 1773, obit. 28.04.1800 Markovicae.

Kilianus à $\mathrm{S}$. Christophoro $\rightarrow$ Kilianus à S. Adamo

Ladislaus à $S$. Antonio $\rightarrow$ Vladislaus à $S$. Antonio

Lambertus à S. Antonio ARP, Szumacher Antonius ${ }^{704}$, ex definitor provinciae, actualis prior loci, nat. 24.03.1743, prof. 22.09.1761 Gedani, presb. 26.12.1765 Posnaniae, obit. 09.09.1788 Plonscii.

${ }^{696}$ AKKr 175/547, s. 569; Zak. 66; Zak. 61, s. 274; ADP, A 41, s. 27: członek konwentu w Gdańsku w 1707. Tonsurę i niższe święcenia otrzymał 24 września 1707 w katedrze w Chełmży z rąk sufragana chełmińskiego Seweryna Szczuki.

${ }^{697}$ AKKr 174/614, s. 37; Kart. 27, s. 414; AKKr 175/547, s. 57; Zak. 66; Zak. 61, s. 29.

${ }^{698}$ AKKr 175/547, s. 511; Zak. 66; Zak. 61, s. 245; TD, Grodzkie i ziemskie-Nakło-Część 1, wpis nr 5864: syn Stanisława i Marianny Grabskiej. W 1707 przebywał w konwencie Bożego Ciała w Poznaniu.

${ }^{699}$ AKKr 174/614, s. 4-5; AKKr 175/547, s. 189; Zak. 66; Zak. 61, s. 94; Kroniczka, s. 90, 92 , 126, 127, 132, 134 i 196: przebywał w klasztorze Bożego Ciała w Poznaniu w 1767. Skierowany w marcu 1768 do rezydencji przy kościele Najświętszej Krwi Pana Jezusa w Poznaniu. Tego samego miesiąca przeniesiony do kościoła w Kórniku, zapewne u Teofili z Działyńskich Szołdrskiej Potulickiej. Powrócił do rezydencji w 1768.

${ }^{700}$ AKKr 175/547, s. 199; Zak. 66; Zak. 61, s. 99: podana data zgonu 9 kwietnia 1726.

${ }^{701}$ AKKr 174/614, s. 4-5; Kart. 27, s. 414: podana data złożenia profesji zakonnej 12 grudnia 1743; AKKr 175/547, s. 465: podana data zgonu 19 sierpnia 1788; Zak. 66: podana data zgonu 24 lipca 1788; Zak. 61, s. 175.

${ }^{702}$ AKKr 174/614, s. 16-17; AKKr 175/547, s. 31 i 79: podany również zgon 9 lutego 1824; Zak. 66: podany zgon 16 stycznia 1824 i 9 marca 1824.

${ }^{703} \mathrm{AKKr}$ 174/614, s. 10-11; AKKr 175/547, s. 237: podane imiona zakonne Kilianus à S. Christophoro; Zak. 66: podana data zgonu 27 kwietnia 1800; Zak. 61, s. 118.

${ }^{704}$ AKKr 174/614, s. 8-9; AKKr 175/547, s. 509; Zak. 66; Zak. 61, s. 244. 
Lambertus à S. Augustino RP, Ronge Augustinus ${ }^{705}$, concionator Germanorum insignis ac musicus praestantissimus, nat. 27.08.1720, prof. 22.12.1741, obit. 23.12.1759 Varsaviae.

Lambertus à S. Francisco ARP, Renkie Franciscus ${ }^{706}$, ex prior Plonscensis, clausit ultimum diem, nat. 21.07.1689, prof. 01.11.1711, presb. 1713, obit. 03.04.1762 Lipiae.

Lambertus à S. Paulo RP, Grabowski Paulus ${ }^{707}$, nat. 11.02.1771.

Lambertus à S. Petro $\mathrm{Fr}^{708}$, sutor, terminarius, nat. 1717, prof. 1745, obit. 12.12.1762 Posnaniae.

Laurentius à S. Antonio $\mathrm{Fr}^{709}$, organarius, obit. 17.03.1752 Plonscii.

Laurentius à S. Antonio Narkiewicz $\mathrm{Fr}^{710}$, terminarius, bene meritus, nat. 1784, prof. 1832, obit. 30.07.1865 Oboriis.

Laurentius à S. Christophoro Fr, Archendt Christophorus ${ }^{711}$, nat. 13.02.1749, prof. 28.08.1769 Posnaniae.

Laurentius à S. Joanne Fr, Kulczycki Joannes ${ }^{712}$, nat. 17.06.1764, prof. 22.10.1789 Posnaniae.

Laurentius à S. Josepho RP, Piotrowski Josephus ${ }^{713}$, subprior loci, pluribus annis procurator pro fabrica ecclesiae Kcynensis, nat. 01.03.1755, prof. 26.10.1773 Gedani, presb. 06.06.1779 Plonscii, obit. in Ostrowo 15.07.1815, sepultus Markovicae.

Laurentius à S. Tiburtio RP ${ }^{714}$, nat. 1675, prof. 1696, obit. 07.08.1709 Posnaniae.

Laurentius à Venerabili Sacramento $\mathrm{Fr}^{715}$, obit. 10.03.1754 Trutoviae.

Laurentius ab Assumptione B.M.V. Fr, Deygowski Laurentius ${ }^{716}$, nat. 09.08.1715, prof. 27.08.1736, obit. 10.03.1754 Trutoviae.

Laurentius ab Assumptione B.M.V. $\mathrm{Fr}^{717}$, nat. 1688, prof. 1709, obit. 06.02.1725 Kcynae.

Laurentius ab Assumptione B.M.V. RP ${ }^{718}$, obiit in obsequio peste infectorum, nat. 1677, prof. 1700, obit. 14.03.1709 Gedani.

Laurentius ab Inventione S. Stephano RP, Celmer Laurentius ${ }^{719}$, ex concionator Polonorum bene commendatus, nat. 12.03.1707, prof. 22.08.1723, presb. 1732, obit. 16.05.1772 Trutoviae.

${ }^{705}$ AKKr 174/614, s. 34: podana data zgonu 24 grudnia 1759; Kart. 27, s. 413; AKKr 175/547, s. 719 ; Zak. 66.

${ }^{706}$ AKKr 174/614, s. 35; Kart. 27, s. 408; AKKr 175/547, s. 187; Zak. 66; Zak. 61, s. 93; Zawadzki, s. 344: w latach 1715-1716 był komendariuszem w Żuławkach w części pomezańskiej diecezji chełmińskiej.

${ }^{707}$ AKKr 174/614, s. 20.

${ }^{708} \mathrm{AKKr}$ 174/614, s. 35: podana data zgonu 12 kwietnia 1762; AKKr 175/547, s. 697; Zak. 66; Zak. 61, s. 102 i 336: podane daty zgonu 12 kwietnia 1762 i 11 grudnia 1762.

${ }^{709}$ AKKr 174/614, s. 32.

${ }^{710}$ AKKr 175/547, s. 425.

${ }^{711}$ AKKr 174/614, s. 24-25.

${ }^{712}$ AKKr 174/614, s. 28.

${ }^{713}$ AKKr 174/614, s. 14-15; AKKr 175/547, s. 415: podana data zgonu 25 lipca 1815; Zak. 66.

${ }^{714}$ AKKr 175/547, s. 441; Zak. 66; Zak. 61, s. 219.

${ }^{715}$ AKKr 174/614, s. 33 .

${ }^{716}$ AKKr 175/547, s. 139; Kart. 25, s. 415; Zak. 66; Zak. 61, s. 69.

${ }^{717}$ AKKr 175/547, s. 73; Zak. 66; Zak. 61, s. 37.

${ }^{718}$ AKKr 175/547, s. 147; Zak. 66: podany rok zgonu 1703; Zak. 61, s. 73.

${ }^{719}$ AKKr 174/614, s. 38; Kart. 27, s. 410; AKKr 175/547, s. 273; Zak. 66; Zak. 61, s. 136. 
Leo à S. Adalberto RP, Radzikowski Seraphinus ${ }^{720}$, nat. 29.12.1735, prof. 15.04 .1753 Posnaniae, presb. 19.03.1759 Varsaviae, obit. 28.03.1777 Nieżuchowo, sepultus apud RR. PP. Bernardinos in Gorki.

Leo à S. Andrea RP ${ }^{721}$, nat. 1683, prof. 1703, obit. 28.10.1709 Gedani.

Leo à S. Andrea Winkowski ARP ${ }^{722}$, pluribus annis ex prior Lipiensis, Guloviensis, Wąsosensis et Klodaviensis, actualis definitor provinciae et prior loci, qui usque ad profectam atatem officium concionatoris laudabiliter exercuit, nat. 1802, prof. 1825, presb. 1826, obit. 24.09.1864 Trutoviae.

Leo à S. Maria Magdalena de Pazzis RP ${ }^{723}$, nat. 1695, prof. 1713, obit. 27.05.1737 Oboriis.

Leo à S. Teresia ARP, Gabrielowicz Florianus ${ }^{724}$, ex prior Plonscensis, Gedanensis et Posnanensis, ex magister novitiorum, nat. 15.05.1678, prof. 15.10.1695, obit. 29.07.1745 Drohobiciis.

Leodegarius à Matre Amabili ARP, Koscielski Michael ${ }^{725}$, ex definitor, ex prior Lipiensis, Bidgostiensis et Varsaviensis, nat. 29.09.1711, prof. 03.10.1730 Posnaniae, presb. 24.03.1735 Markovicae, obit. 08.02.1787 Markovicae.

\section{Leodegarius à Matre Eva $\rightarrow$ Leodegarius à Matre Amabili}

Leonardus à S. Francisco Fr, Zielinski Franciscus ${ }^{726}$, nat. 02.10.1745, prof. 16.10.1777 Gedani.

Leonardus à S. Joanne à Cruce ARP, Węgierski Petrus ${ }^{727}$, STL, jubilatus, bis ex definitor, ex praeses capituli, ex prior Bidgostiensis et loci, nat. 29.06.1705, prof. 19.12.1723, obit. 05.06.1755 Gedani.

Leonardus à S. Joanne RP, Graw Joannes ${ }^{728}$, nat. 29.03.1743, prof. $16.11 .1769 \mathrm{Ge}-$ dani, presb. 10.06.1770 Gedani, obit. 10.05.1810 Posnaniae in oratorio Sanguinis Christi.

${ }^{720}$ AKKr 174/614, s. 6-7 i 40: błędnie na s. 6-7 podane, że zmarł w Kcyni; AKKr 175/547, s. 175; Zak. 66; Zak. 61, s. 87; Mańkowski, Liber mortuorum, s. 68: konfrater cystersów koronowskich.

${ }^{721}$ AKKr 175/547, s. 607; Zak. 66; Zak. 61, s. 293.

${ }^{722}$ AKKr 175/547, s. 539; Zak. 66.

${ }^{723}$ AKKr 175/547, s. 295; Zak. 66; Zak. 61, s. 147.

${ }^{724}$ AKKr 174/614, s. 31; Kart. 27, s. 407; AKKr 175/547, s. 155; Zak. 66; Zak. 61, s. 77 i 203 : podane daty zgonu 18 marca 1744 i 22 lipca 1745.

${ }^{725}$ AKKr 174/614, s. 2-3; Kart. 27, s. 411; Zak. 66; AKKr 175/547, s. 77 i 85: drugi zapis zgonu 12 lutego 1787; Zak. 61, s. 39; ADP, A 16, s. 34 i 35: członek konwentu w Poznaniu w 1735. Święcenia diakonatu otrzymał 6 marca 1735 i prezbiteratu 6 marca 1735 w kościele parafialnym w Lubawie z rąk sufragana chełmińskiego Macieja Aleksandra Sołtyka; Kroniczka, s. 40 i 192: w 1730 przebywał w klasztorze Bożego Ciała w Poznaniu. Definitor prowincji w 1736.

${ }^{726}$ AKKr 174/614, s. 26-27.

${ }^{727}$ AKKr 174/614, s. 33; Kart. 27, s. 410; AKKr 175/547, s. 313; Zak. 66; Zak. 61, s. 156; Zakonnicy, s. 334; Nowicki, Stownik biograficzny, s. 226; Ad historiam ecclesiasticam Pomeraniae apparatus pauper subsidia literaria poscens a viris bonis et doctis collectus ad interim a Georgio Schwengel Carthusiae priore 1749, curavit Bruno Czapla, [w:] „Fontes Towarzystwa Naukowego w Toruniu", 16-19: 1912-1915, s. 238 i 485; Encyklopedia wiedzy o Jezuitach na ziemich Polski i Litwy 1564-1995, opr. L. Grzebień SJ, Kraków 2004, s. 729: syn Jana i Barbary Pałubickiej. Jego brat Jan Marcin (1693-1731) był w latach 1716-1731 proboszczem w Goręczynie. W zakonie karmelitów trzewiczkowych miał brata Urbana, a jezuitów Andrzeja (1695-1757).

${ }^{728}$ AKKr 174/614, s. 12-13; AKKr 175/547, s. 261; Zak. 66. 
Leonardus à S. Petro ARP ${ }^{729}$, prior Oboriensis et procurator provinciae, nat. 1689, prof. 1705, obit. 15.02.1722 Olomunci in Moraviae, obiit in itinere Romano.

Leopoldus à S. Josepho ARP, Blöhr Josephus ${ }^{730}$, STL, ex provincialis, ex prior Posnaniensis, comissarius generalis, nat. 27.02.1762, prof. 06.12.1784 Gedani, presb. 1787, obit. 19.05.1821 Posnaniae.

Leopoldus à S. Quirino RP, Cerbs Joannes ${ }^{731}$, capellanus perpetuus, nat. 25.06.1715, prof. 27.06.1731 Gedani, presb. 25.08.1740, Varsaviae, obit. 16.05.1780 in villa Srebrne Gorki, sepultus Kcynae.

Leopoldus Trepczyk RP ${ }^{732}$, ex professor theologiae moralis, ex dispositione V. Capituli concionator Lipienensis, nat. 1800, prof. 1832, presb. 1832, obit. 03.05.1838 Działyń.

Leopoldus Zegan RP ${ }^{733}$, nat. 1810, prof. 1828, obit. 07.06.1870 Oboriis.

Liborius à S. Andrea RP, Damborski (Daberski) Andreas ${ }^{734}$, ex vicarius Plonscensis, promotor S. Rosarii et SS. Scapularis, nat. 11.05.1756, prof. 09.08.1779 Posnaniae, presb. 24.03.1788 Posnaniae, obit. 22.09.1831 Plonscii.

Longinus à S. Josepho RP, Szejski Josephus ${ }^{735}$, ex lector philosophiae, ex magister novitiorum, nat. 13.03.1744, prof. 09.04.1771 Gedani, presb. 14.07.1771 Gedani, obit. 11.04.1805 Kcynae.

Longinus à S. Martino $\mathrm{RP}^{736}$, ex subprior Lipiensis, actualis procurator Posnaniensis, nat. 1729, prof. 1751, obit. 28.10.1769 Posnaniae.

Longinus Pittat $\mathrm{Fr}^{737}$, prof. Gedani.

Lucas à S. Andrea ARP, Link Andreas ${ }^{738}$, emeritus, ex concionator Germanorum, ex prior Klodaviensis, ex magister novitiorum Posnaniensis, actualis subprior loci, nat. 02.01.1700, prof. 28.09.1719, obit. 25.07.1753 Varsaviae.

Lucas à S. Antonio ARP, Gręca Antonius ${ }^{739}$, STL, ex provincialis, ex definitor, ex prior Gedanensis, nat. 18.10.1750, prof. 23.10.1766 Gedani, presb. 06.01.1774 Posnaniae, obit. 04.10.1807 Gedani.

${ }^{729}$ AKKr 175/547, s. 91; Zak. 66; Zak. 61, s. 46.

${ }^{730}$ AKKr 174/614, s. 18-19; AKKr 175/547, s. 279; Zak. 66.

${ }^{731}$ AKKr 174/614, s. 2-3; Kart. 27, s. 411: podana data urodzenia 26 czerwca 1715; AKKr 175/547, s. 273; Zak. 66: podana data zgonu 17 maja 1780; Zak. 61, s. 136.

${ }^{732}$ AKKr 175/547, s. 267: podana data zgonu 13 maja 1838; Zak. 66.

${ }^{733}$ AKKr 175/547, s. 317.

${ }^{734}$ AKKr 174/614, s. 16-17; AKKr 175/547, s. 535; Zak. 66: podana data zgonu 9 stycznia 1832.

${ }^{735}$ AKKr 174/614, s. 12-13; Zak. 66; Zak. 61, s. 101.

${ }^{736}$ AKKr 174/614, s. 37; AKKr 175/547, s. 609; Zak. 66; Zak. 61, s. 293; Kroniczka, s. 65, 77 i 194: wybrany wikariuszem konwentu Bożego Ciała w lutym 1766. Przybył do rezydencji przy kościele Najświętszej Krwi Pana Jezusa w Poznaniu w sierpniu 1766 z klasztoru w Oborach. Po kilkunastu dniach przeniesiony do klasztoru w Kcyni.

${ }^{737}$ AKKr 174/614, s. 28: w rękopisie brak dat.

${ }^{738}$ AKKr 174/614, s. 33: podana data zgonu 22 sierpnia 1753; Kart. 27, s. 409; AKKr 175/547, s. 415; Zak. 66; Zak. 61, s. 206 i 227: zapis z datą zgonu 25 lipca 1753 przekreślony i podana data zgonu 22 sierpnia 1753.

${ }^{739}$ AKKr 174/614, s. 10-11; AKKr 175/547 s. 559; Zak. 66: podana data zgonu 5 października 1807; Zak. 61, s. 270: podana data zgonu 5 października 1807; Zakonnicy, s. 336: data zgonu 5 października 1807 i nazwisko Grercza. 
Lucas à S. Michaele $\mathrm{Fr}^{740}$, nat. 1695, prof. 1720, obit. 21.12.1744 Posnaniae.

Lucas à S. Paulo Fr, Żolądkiewicz Paulus ${ }^{741}$, nat. 11.01.1767, prof. 22.10.1789 Posnaniae.

Lucas à S. Petro $\mathrm{Fr}^{742}$ sartor, nat. 1706, prof. 1733, obit. 28.02.1772 Lipiae.

Lucas à S. Thoma Fr, Dluzniewski Thomas ${ }^{743}$, sartor, terminarius, nat. 21.06.1715, prof. 08.11.1755 Gedani, obit. 26.10.1775 Klodaviae.

Lucas Czapkowski RP ${ }^{744}$, concionator Germanorum, nat. 1788, prof. 1809, obit. 18.10.1826 Gedani.

Ludovicus à S. Andrea $\mathrm{Fr}^{745}$, musicus, nat. 1693, prof. 1714, obit. 09.01.1744 Posnaniae.

Ludovicus à S. Hyacintho ARP, Charazniewicz Petrus Caelestinus ${ }^{746}$, ex secretarius et ex definitor provinciae, ex prior Oboriensis per plura triennia, nat. 19.05.1723, prof. 19.08.1741 Posnaniae, presb. 16.07.1748 Varsaviae, obit. 17.07.1782 Oboriis.

Ludovicus à S. Ignatio RP, Szandel Ignatius ${ }^{747}$, nat. 01.08.1754, prof. 1783 Gedani, presb. 22.05.1788 Plonscii, obit. 19.05.1798 Lipiae.

Ludovicus à S. Josepho Cierpisz $\mathrm{RP}^{748}$, ex subprior Guloviensis, ex magister novitiorum, post supressionem monasteriorum per multos annos vicarius parochialis Guloviae, tandem laborans infirmitate oculorum, ad conventum Oboriensem translatus, ibique dies suos numeravit ultimos, vir morigeratus ac ascteticus; cuius animae det Deus pacem, nat. 1825, prof. 1844, presb. 1850, obit. 28.05.1898 Oboriis.

Ludovicus à S. Josepho Fr, Wliklinski Josephus ${ }^{749}$, terminarius, nat. 05.03.1714, prof. 19.03.1746 Posnaniae, obit. 21.11.1792 Markovicae.

Ludovicus à $\mathbf{S}$. Spiridione $\mathrm{RP}^{750}$, ex concionator Germanorum, subprior loci, nat. 1660, prof. 1690, obit. 17.05.1709 Gedani.

${ }^{740} \mathrm{AKKr} 174 / 614$, s. 31: podana data zgonu 22 października 1744 i informacja, że był nowicjuszem; AKKr 175/547, s. 715; Zak. 66.

${ }^{741}$ AKKr 174/614, s. 28.

${ }^{742}$ AKKr 174/614, s. 38; AKKr 175/547, s. 115; Zak. 66; Zak. 61, s. 58: podana data zgonu 27 lutego 1772.

${ }^{743}$ AKKr 174/614, s. 22-23 i 39; AKKr 175/547, s. 603; Zak. 66; Zak. 61, s. 291.

${ }^{744}$ AKKr 175/547, s. 607: podana data zgonu 28 października 1827; Zak. 66; AA Gdańsk Oliwa, Parafia Św. Brygidy w Gdańsku, sygn. D 47, brak paginacji: Michał Schopkowski urodził się w 1788 w Gdańsku w rodzinie Franciszka i Anny. Ochrzcił go przeor Szymon Hennig 21 września 1788 w kościele Św. Brygidy, chrzestnymi byli Albert Weiss, Paweł Müller i Anna Schirbotsche. Do zakonu karmelitów wstąpił 23 stycznia 1808. Profesję zakonną złożył w 1809. Kaznodzieja niemiecki w Gdańsku w latach 1817-1826.

${ }^{745} \mathrm{AKKr} 174 / 614$, s. 31; AKKr 175/547, s. 17; Zak. 66; Zak. 61, s. 9: podana data zgonu 9 stycznia 1743.

${ }^{746}$ AKKr 174/614, s. $4-5$ i 42; Kart. 27, s. 413: podana data urodzenia 28 maja 1723; AKKr 175/547, s. 399; Zak. 66: podana data zgonu 17 czerwca 1782; Zak. 61, s. 198.

${ }^{747}$ AKKr 174/614, s. 16-17; Zak. 66; Zak. 61, s. 139.

${ }^{748}$ AKKr 175/547, s. 297; Zak. 66.

${ }^{749}$ AKKr 174/614, s. 22-23; AKKr 175/547, s. 723: podana data zgonu 25 grudnia 1792; Zak. 66: podana data zgonu 25 października 1792.

${ }^{750} \mathrm{AKKr}$ 175/547, s. 275 i 453: podana druga data zgonu 13 sierpnia 1709 w Oborach; Zak. 66: podana druga data zgonu 13 sierpnia $1709 \mathrm{w}$ Oborach; Zak. 61, s. 137. 
Ludovicus à S. Thoma ARP, Sierawski Thomas ${ }^{751}$, ex provincialis, bis praeses capituli, bis primitians, pluribus annis magister novitiorum, ex prior Plonscensis, Lipiensis, Kcynensis, Bidgostiensis, Varsaviensis et Posnaniensis, in orando fere assiduus, nat. 20.06.1689, prof. 15.03.1711, obit. 12.04.1770 Lipiae.

Ludovicus Grębski RP ${ }^{752}$, ex magister clericorum, per aliquot annos commorans in Conventu nostro Trembloviensi; propter frigora contraxit sibi diuturnum morbum renum, qua de causa praemature a vita migravit in aetate 33 annorum multos diuturnosque dolores perpessus, obdormivit in Conventu nostro in Arenis, obit. 29.11.1919 Cracoviae.

Macarius à S. Andrea RP, Wichert Andreas ${ }^{753}$, nat. 16.11.1751, prof. 09.04.1771 Gedani, presb. 19.03.1776 Varsaviae.

Mansvetus à S. Casto RP, Zaborowski Josephus ${ }^{754}$, nat. 27.02.1713, prof. 02.09.1731.

Mansvetus à S. Joanne Duszynski RP ${ }^{755}$, STL, a Conventu Varsaviensi paternam domum in Bobrowniki aegra valetudine discessus, ibidem e vivis decessit, nat. 1833, prof. 1851, presb. 1856, obit. 10.05.1857 Bobrowniki, sepultus in caematerio parochiali in Bobrowniki.

Mansvetus à S. Valentino ARP, Grenca (Grentz) Valentinus ${ }^{756}$, STL, ex prior Plonscensis, ex definitor, nat. 14.02.1765, prof. 25.09.1781 Gedani, presb. 1788 Varsaviae, obit. 08.04.1813 Plonscii.

Marcellinus à S. Andrea RP, Austen Andreas ${ }^{757}$, lector philosophiae, nat. 10.02.1743, prof. 08.11.1765 Gedani, presb. 29.06.1769 Varsaviae, obit. 13.03.1822 Oboriis.

Marcellinus à S. Cruce RP ${ }^{758}$, nat. 1643, prof. 1664, obit. 25.08.1677 Oboriis.

Marcellinus à S. Jacobo RP ${ }^{759}$, seniculus, nat. 1617, obit. 11.01.1677 Oboriis.

Marcellinus à S. Joanne Rzeszotarski ARP ${ }^{760}$, prior loci, definitor, nat. 1804, prof. 1827, presb. 1828, obit. 10.04.1862 Plonscii.

Marcellinus à S. Luca RP ${ }^{761}$, nat. 1628, prof. 1658, obit. 04.09.1677 Bidgostiae.

Marcellinus à S. Spiritu $\mathrm{ARP}^{762}$, prior loci, nat. 1656, prof. 1683, obit. 28.08.1705 Oboriis.

Marcellinus à Venerabili Sacramento RP, Krassowski Bernardus ${ }^{763}$, nat. 19.05.1709, prof. 11.08.1725, obit. 10.12.1753 Klodaviae.

${ }^{751}$ AKKr 174/614, s. 37; Kart. 27, s. 408; AKKr 175/547, s. 205; Zak. 66; Zak. 61, s. 102.

${ }^{752}$ AKKr 175/547, s. 671.

${ }^{753}$ AKKr 174/614, s. 12-13.

${ }^{754}$ Kart. 27, s. 411.

${ }^{755}$ AKKr 175/547, s. 261; Zak. 66.

${ }^{756}$ AKKr 174/614, s. 16-17; AKKr 175/547, s. 183 i 197: podana na s. 183 data zgonu 1 kwietnia 1813, na s. 197 podana data urodzenia 19 lutego 1765; Zak. 66.

${ }^{757}$ AKKr 174/614, s. 10-11; AKKr 175/547, s. 145; Zak. 66.

${ }^{758}$ AKKr 175/547, s. 479; Zak. 66.

${ }^{759}$ AKKr 175/547, s. 21; Zak. 66; Zak. 61, s. 11.

${ }^{760} \mathrm{AKKr} 175 / 547$, s. 201; Zak. 66.

${ }^{761}$ AKKr 175/547, s. 499; Zak. 66; Zak. 61, s. 235 i 236: podane daty zgonu 31 sierpnia i 1 września 1677.

${ }^{762}$ AKKr 175/547, s. 485; Zak. 66; Zak. 61, s. 232.

${ }^{763}$ AKKr 174/614, s. 33; Kart. 27, s. 410; AKKr 175/547, s. 693; Zak. 66; Zak. 61, s. 335. 
Marcellus à S. Norberto $\mathrm{ARP}^{764}$, ex prior Gedanensis, nat. 1661, prof. 1681, obit. 17.07.1711 Posnaniae.

Marcianus à S. Ignatio RP, Zagrodzki Ignatius ${ }^{765}$, nat. 24.07.1755, prof. 29.12.1772 Posnaniae, presb. 13.09.1778 Varsaviae, in provinciae Minoris Poloniae.

Marcianus à S. Josepho ARP, Schwald Josephus ${ }^{766}$, STL, jubilatus, concionator Polonorum, quoad sanam doctrinam et oris gratiam celebris, prior loci, nat. 25.03.1715, prof. 21.05.1731, obit. 30.07.1758 Posnaniae.

Marcianus à S. Petro RP, Walnowski Petrus ${ }^{767}$, nat. 26.06.1767, prof. 11.03.1789 Posnaniae.

Marcus à S. Thadeo Zmigrodzki RP ${ }^{768}$, nat. 1838, presb. 1866, obit. 06.02.1874 Oboriis.

Marianus à S. Antonio RP, Stęfikiewicz Antonius ${ }^{769}$, nat. 04.06.1746, prof. 11.09.1768 Posnaniae, presb. 08.12.1770 Kcynae, [obiit] in Russia [in Conventu] Discalceatorum.

Marianus à S. Josepho $\mathrm{RP}^{770}$, concionator, nat. 1673, prof. 1689, obit. 25.03.1706 Drohobiciis.

Marianus à S. Maria Magdalena de Pazzis RP ${ }^{771}$, subprior loci, nat. 1655, prof. 1673, obit. 15.11.1695 Gedani.

Marianus à S. Nicomede RP, Rauthe Venceslaus ${ }^{772}$, musicus, nat. 30.06.1719, prof. 21.09.1742, obit. 01.11.1766 Markovicae.

Marianus à S. Spiridione ARP, Wylązek Albertus ${ }^{773}$, bene commendatus, concionator Polonorum, ex prior Drohobicensis, nat. 16.04.1690, prof. 11.09.1708, obit. 09.08.1751 Kcynae.

Marianus à S. Teresia ARP ${ }^{774}$, ex prior Posnaniensis, ex prior loci, nat. 1655, prof. 1674, obit. 10.05.1694 Bidgostiae.

Marianus Machajewski Fr ${ }^{775}$, nat. 1903, obit. 08.12.1928 Leopoli.

Marinus à S. Euphrosina RP ${ }^{776}$, nat. 1646, prof. 1663, obit. 07.01.1694 Gedani.

Marinus à S. Matre Dei RP ${ }^{777}$, nat. 1654, prof. 1673, obit. 12.06.1694 Bidgostiae.

${ }^{764}$ AKKr 175/547, s. 399; Zak. 66; Zak. 61, s. 197 i 198: podana druga data zgonu 16 lipca 1711.

${ }^{765}$ AKKr 174/614, s. 12-13; ADP, C 54a, s. 124: członek konwentu w Gdańsku w 1775. Tonsurę i niższe święcenia otrzymał 25 maja 1775 w kościele św. Wojciecha pod Gdańskiem z rąk sufragana chełmińskiego Franciszka Fabiana Pląskowskiego.

${ }^{766}$ AKKr 174/614, s. 34; Kart. 27, s. 411; AKKr 175/547, s. 425; Zak. 66; Zak. 61, s. 211.

${ }^{767}$ AKKr 174/614, s. 18-19.

${ }^{768}$ AKKr $175 / 547$, s. 73

${ }^{769}$ AKKr 174/614, s. 10-11.

${ }^{770}$ AKKr 175/547, s. 169; Zak. 66; Zak. 61, s. 84.

${ }^{771}$ AKKr 175/547, s. 643; Zak. 66; Zak. 61, s. 310: podana data zgonu 14 listopada 1694.

${ }^{772}$ AKKr 174/614, s. 36: podana data zgonu 3 listopada 1766; Kart. 27, s. 413; AKKr 175/547, s. 615; Zak. 66; Zak. 61, s. 299: podana data zgonu 3 listopada 1766.

${ }^{773}$ AKKr 174/614, s. 32; Kart. 27, s. 408; AKKr 175/547, s. 445; Zak. 66; Zak. 61, s. 221.

${ }^{774}$ AKKr 175/547, s. 261; Zak. 66; Zak. 61, s. 130.

${ }^{775}$ AKKr 175/547, s. 689.

${ }^{776}$ AKKr 175/547, s. 13: w rękopisie podany rok zgonu 1692; Zak. 66; Zak. 61, s. 7.

${ }^{777}$ AKKr 175/547, s. 327; Zak. 66. 
Martialis à S. Jacobo RP, Biess Jacobus ${ }^{778}$, pluribus annis exorcista loci, nat. 27.03.1750, prof. 28.11.1776 Gedani, presb. 15.08.1777 Gedani, obit. 16.08.1807 Markovicae.

Martinianus à Matre Dolorosa $\mathrm{Fr}^{779}$, nat. 1664, prof. 1691, obit. 16.04.1722 Posnaniae.

Martinianus à S. Adalberto RP, Kutski (Kuczkie, Kutzkie) Adalbertus ${ }^{780}$, STL, ex lector philosophiae, nat. 25.04.1763, prof. 17.02.1780 Gedani, presb. 02.07.1786 Posnaniae, obit. 06.04.1825 Kcynae.

Martinianus à S. Anna Fr, Konarzewski Stephanus ${ }^{781}$, terminarius, nat. 16.11.1691, prof. 08.08.1735, obit. 26.07.1752 Posnaniae.

Martinianus à S. Gabriele $\mathrm{Fr}^{782}$, nat. 1659, prof. 1681, obit. 20.10.1709 Gedani.

Martinianus à S. Joanne Fr, Hantchel Joannes ${ }^{783}$, terminarius, hostis otii, diligens ac exemplaris collector elemosynae, nat. 22.04.1736, prof. 29.07.1768 Posnaniae, obit. 17.08.1806 Varsoviae.

Martinus à Monte Carmelo RP ${ }^{784}$, nat. 1654, prof. 1672, obit. 21.03.1682 Posnaniae.

Martinus à S. Andrea ARP ${ }^{785}$, prior loci, nat. 1644, prof. 1662, obit. 26.09.1679 Posnaniae.

Martinus à S. Andrea $\mathrm{Fr}^{786}$, nat. 1675, prof. 1694, obit. 07.03.1704 Posnaniae.

Martinus à S. Didaco ARP, Kramer Joannes ${ }^{787}$, ex magister novitiorum, ex prior Markovicensis, prior loci, nat. 28.03.1690, prof. 16.11.1710, obit. 05.11.1756 Lipiae.

Martinus à S. Lazaro RP ${ }^{788}$, nat. 1634, prof. 1662, obit. 23.05.1699 Posnaniae.

Martinus à S. Nicolao $\mathrm{Fr}^{789}$, nat. 1672, prof. 1693, obit. 07.09.1708 Varsaviae.

Martinus à S. Nicolao RP ${ }^{790}$, nat. 1673, prof. 1695, obit. 06.06.1709 Varsaviae.

${ }^{778}$ AKKr 174/614, s. 14-15; AKKr 175/547, s. 459; Zak. 66: podana data zgonu 15 września 1807; Zak. 61, s. 251; ADP, C 54a, s. 109 i 127: członek konwentu w Gdańsku w 1777. Święcenia subdiakonatu otrzymał 17 sierpnia 1777 w kościele karmelitów w Gdańsku, diakonatu 6 grudnia 1777 i prezbiteratu 8 grudnia 1777 w Chełmży z rąk sufragana chełmińskiego Franciszka Fabiana Pląskowskiego.

${ }^{779}$ AKKr 175/547, s. 213; Zak. 66; Zak. 61, s. 106.

${ }^{780} \mathrm{AKKr} 174 / 614$, s. 16-17; AKKr 175/547, s. 195: podana data zgonu 7 kwietnia 1825; Zak. 66.

${ }^{781}$ AKKr 174/614, s. 33: podana data zgonu 16 czerwca 1752; Kart. 27, s. 415; AKKr 175/547, s. 417; Zak. 66; Zak. 61, s. 197: podana data zgonu 16 lipca 1752.

${ }^{782} \mathrm{AKKr}$ 175/547, s. 591; Zak. 66; Zak. 61, s. 284: podana data zgonu 19 października 1709.

${ }^{783}$ AKKr 174/614, s. 24-25; AKKr 175/547, s. 465: podana data zgonu 19 sierpnia 1806; Zak. 66; Zak. 61, s. 223: podana data zgonu 19 sierpnia 1806.

${ }^{784} \mathrm{AKKr}$ 175/547, s. 161: podany data zgonu 21 marca 1782; Zak. 66; Zak. 61, s. 80.

${ }^{785}$ AKKr 175/547, s. 543; Zak. 66; Zak. 61, s. 261.

${ }^{786}$ AKKr 175/547, s. 133; Zak. 66; Zak. 61, s. 65 i 214: podana data zgonu 6 marca i 2 sierpnia 1704.

${ }^{787}$ AKKr 174/614, s. 33: podana data zgonu 5 marca 1756; Kart. 27, s. 408; AKKr 175/547, s. 623; Zak. 66; Zak. 61, s. 301 i 64: podana data zgonu 5 marca 1756.

${ }^{788}$ AKKr 175/547, s. 287; Zak. 66; Zak. 61, s. 143.

${ }^{789}$ AKKr 175/547, s. 505; Zak. 66; Zak. 61, s. 242.

${ }^{790} \mathrm{AKKr}$ 175/547, s. 315; Zak. 66; Zak. 61, s. 160: podana data zgonu 9 czerwca 1709. 
Martinus à S. Petro ARP, Neuman Petrus ${ }^{791}$, STL, ex magister novitiorum, ex prior Gedanensis, Plonsensis et Varsaviensis, ex definitor provinciae, prior loci, nat. 22.09.1740, prof. 15.06.1761 Gedani, presb. 18.07.1765 Posnaniae, obit. 06.04.1796 Bidgostiae.

Martinus Brzanski RP ${ }^{792}$, ex professor clericorum, nat. 1781, prof. 1801, obit. 04.08.1831 Guloviae.

Martinus Maciak ARP ${ }^{793}$, ex prior Sąsiadovicensis et Cracoviensis et novissime provincialis Provinciae Sancti Joseph in Galicia, bonus concionator, auctor libelli "De coronatione Thaumaturgae Imaginis B.M.Virginis in Arenis Cracoviae” et libelli „Zdrój łask i przywilejów w świętej sukni Szkaplerza Najświętszej Maryi Panny z Góry Karmel" editi Leopoli 1916, propter meningitim e vita decessit, nat. 1876, obit. 31.12.1922 Cracoviae.

Mathaeus à S. Adalberto Miaskowski $\mathrm{Fr}^{794}$, clericus, nat. 1789, prof. 1802, obit. 19.07.1812 Posnaniae.

Mathaeus à S. Antonio RP, Alscher Antonius ${ }^{795}$, nat. 05.06.1757, prof. 26.10.1775 Gedani, presb. 25.12.1780 Varsaviae, obit. 19.04.1807 Plonscii.

Mathaeus à S. Jacobo $\mathrm{Fr}^{796}$, tegularis, nat. 1718, prof. 1745, obit. 29.02.1760 Klodaviae.

Mathaeus à S. Joanne Radoszewski RP ${ }^{797}$, nat. 1710, prof. 1727, obit. 13.06.1735 Gedani, celebratis 30 Missae Sacrificiis.

Mathaeus à S. Joanne RP, Fischer Joannes ${ }^{798}$, nat. 28.08.1719, prof. 05.06.1741, obit. 03.06.1771 Plonscii.

Mathaeus à S. Laurentio $\rightarrow$ Mathaeus à S. Jacobo

Mathaeus Zanc $\mathrm{Fr}^{799}$, coquus in xenodochio, nat. 1824, obit. 30.05.1874 Lublini.

${ }^{791}$ AKKr 174/614, s. 8-9; AKKr 175/547, s. 211: podana data zgonu 15 kwietnia 1796; Zak. 66; Zak. 61, s. 98: podana data zgonu 8 kwietnia 1796; Mańkowski, Liber mortuorum, s. 114: podana data zgonu 8 kwietnia 1796. Konfrater cystersów koronowskich; ADP, C 54a, s. 53: członek konwentu w Gdańsku w 1763. Tonsurę i niższe święcenia otrzymał 12 czerwca 1763 w Starogrodzie z rąk sufragana chełmińskiego Franciszka Fabiana Pląskowskiego; Kroniczka, s. 77, 110 i 195: student teologii w 1766. Przebywał w rezydencji przy kościele Najświętszej Krwi Pana Jezusa w Poznaniu w 1768.

${ }^{792}$ Zak. 66.

${ }^{793}$ AKKr 175/547, s. 735.

${ }^{794}$ AKKr 175/547, s. 403; Zak. 66: podana data zgonu 11 lipca 1812.

${ }^{795}$ AKKr 174/614, s. 14-15; AKKr 175/547, s. 219; Zak. 66; Zak. 61, s. 109.

${ }^{796}$ AKKr 174/614, s. 34: podana data zgonu 27 lutego 1760; AKKr 175/547, s. 119; Zak. 66; Zak. 61, s. 58: podana data zgonu 27 lutego 1760 oraz imiona zakonne Mathaeus à S. Laurentio.

${ }^{797}$ AKKr 175/547, s. 329; Zak. 66; Zak. 61, s. 164; Zakonnicy, s. 333: podany tylko rok zgonu; ADP, A 16, s. 34 i 35: członek konwentu w Markowicach w 1735. Święcenia subdiakonatu otrzymał 4 marca 1735, diakonatu 6 marca 1735 i prezbiteratu 8 marca 1735 w kościele parafialnym w Lubawie z rąk sufragana chełmińskiego Macieja Aleksandra Sołtyka.

${ }^{798}$ AKKr 174/614, s. 38; Kart. 27, s. 413; AKKr 175/547, s. 309; Zak. 66; Zak. 61, s. 154: Kroniczka, s. 30, 34 i 190: do 1763 przebywał w klasztorze w Kłodawie. W rezydencji przy kościele Najświętszej Krwi Pana Jezusa w Poznaniu od sierpnia do końca 1763. Był następnie kapelanem kasztelanowej biechowskiej prawdopodobnie Agnieszki Zakrzewskiej.

${ }^{799}$ AKKr 175/547, s. 301. 
Mathias à S. Casimiro Fr, Moderski Antonius ${ }^{800}$, terminarius exemplaris, nat. 11.07.1708, prof. 05.03.1738, obit. 06.10.1749 Bidgostiae.

Mathias à S. Joanne RP, Ditloff Joannes ${ }^{801}$, nat. 30.01.1750, prof. 24.08.1769 Gedani, in Provinciae Russiae.

Mathias à S. Leone RP, Berendt Adalbertus ${ }^{802}$, actualis procurator loci, nat. 02.05.1726, prof. 09.07.1743, obit. 31.07.1763 Klodaviae.

Mathias à S. Mathaeo $\mathrm{Fr}^{803}$, nat. 1759, prof. 1780, obit. 27.08.1799 Lipiae.

Mathias à S. Mathaeo $\mathrm{Fr}^{804}$, pictor, nat. 1722, prof. 1751, obit. 18.07.1771 Lipiae.

Mathias à S. Stanislao $\mathrm{Fr}^{805}$, piscator, nat. 1670, prof. 1690, obit. 21.02.1720 Oboriis.

Mathias Bury Fr ${ }^{806}$, coquus, nat. 1904, prof. 1928, obit. 23.12.1936 Trembowla.

Mathias $\mathrm{Fr}^{807}$, obit. 12.02.1750 Posnaniae.

Mathias Kalinowski $\mathrm{Fr}^{808}$, tertiarius, nat. 1770, obit. 21.03.1828 Trutoviae.

Mauritius à S. Fabiano $\mathrm{Fr}^{809}$, nat. 1701, prof. 1721, obit. 13.05.1735 Drohobiciis.

Mauritius à S. Georgio (Gorgonio) Fr, Taszewski Michael ${ }^{810}$, dispensator et terminarius exemplaris, sartor, nat. 20.09.1711, prof. 12.09.1740 Posnaniae, obit. 28.12.1773 Trutoviae.

Mauritius à S. Jacobo Fr, Siekowicz Jacobus ${ }^{811}$, nat. 03.07.1744, prof. 08.09.1776 Posnaniae.

Maximus à Matre Dei RP ${ }^{812}$, obit. 12.06.1694 Bidgostiae.

Maximus à S. Philippo $\mathrm{Fr}^{813}$, pannifex, nat. 1728, prof. 1751, obit. 02.05.1763 Posnaniae.

Medardus à S. Mathia RP, Sulejowski Mathias ${ }^{814}$, ex lector philosophiae, ex subprior in variis conventibus, nat. 28.02.1745, prof. 15.06.1761 Gedani, presb. 17.04.1768 Varsaviae, obit. 09.06.1800 Posnaniae.

${ }^{800}$ AKKr 174/614, s. 32: podana data zgonu 3 października 1749; Kart. 27, s. 415; AKKr 175/547, s. 403; Zak. 66; Zak. 61, s. 271.

${ }^{801}$ AKKr 174/614, s. 10-11.

${ }^{802}$ AKKr 174/614, s. 37: podana data zgonu 30 lipca 1768; Kart. 27, s. 413; AKKr 175/547, s. 427; Zak. 66; Zak. 61, s. 211: podana data zgonu 30 lipca 1768.

${ }^{803}$ AKKr 175/547, s. 483; Zak. 66; Zak. 61, s. 221: podana data zgonu 9 sierpnia 1799.

${ }^{804}$ AKKr 174/614, s. 38; AKKr 175/547, s. 403; Zak. 66; Zak. 61, s. 199.

${ }^{805}$ AKKr 175/547, s. 103; Zak. 66; Zak. 61, s. 52.

${ }^{806} \mathrm{AKKr} 175 / 547$, s. 719.

${ }^{807}$ Zak. 61, s. 43.

${ }^{808}$ AKKr 175/547, s. 161.

${ }^{809}$ AKKr 175/547, s. 267; Zak. 66; Zak. 61, s. 133.

${ }^{810}$ AKKr 174/614, s. 22-23 i 38; Kart. 27, s. 415: podana data urodzenia 2 września 1711; AKKr 175/547, s. 729; Zak. 66; Kroniczka, s. 168 i 200: błędnie określony jako ojciec. Przybył do rezydencji przy kościele Najświętszej Krwi Pana Jezusa w Poznaniu w czerwcu 1769 z klasztoru w Płońsku.

${ }^{811}$ AKKr 174/614, s. 26-27.

${ }^{812}$ Zak. 61, s. 163.

${ }^{813}$ AKKr 174/614, s. 36; AKKr 175/547, s. 245; Zak. 66; Zak. 61, s. 121: podana data zgonu 1 maja 1763.

${ }^{814}$ AKKr 174/614, s. 8-9; AKKr 175/547, s. 321; Zak. 61, s. 160. 
Melchior à S. Joanne Baptista ARP, Kwasniewski Joannes ${ }^{815}$, STL, jubilatus, ex prior Posnaniensis, concionator Polonorum, actualis definitor provinciae, nat. 02.02.1727, prof. 13.03.1743, obit. 15.04.1773 Kcynae.

Melchior à S. Joanne Fr ${ }^{816}$, sculptor, nat. 1695, prof. 1747, obit. 05.11.1755 Kcynae.

Melchior à S. Laurentio ARP, Pierzcinski (Perczyński) Laurentius ${ }^{817}$, definitor et prior loci, nat. 29.08.1756, prof. 05.02.1783 Gedani, presb. 21.07.1783 Gedani, obit. 02.01.1830 Oboriis.

Melchior Sperowski RP ${ }^{818}$, antiquae regularis observantiae ex Provincia Vilnensi affiliatus nostrae Provinciae; in nostra annorum 18 exstitit, nat. 1796, prof. 1818, presb. 1822, obit. 20.11.1851 Guloviae.

Mennas à S. Thoma Fr, Zinrow (Zyngier) Thomas ${ }^{819}$, quaestarius, nat. 18.10.1758, prof. 13.12.1779 Gedani, obit. 30.05.1813 Markovicae.

Methodius à S. Martino RP, Schultz Martinus ${ }^{820}$, nat. 09.04.1757, prof. 08.05.1777 Gedani, presb. 10.09.1785 Gedani, obit. 07.10.1795 Kcynae.

Michael à S. Adalberto Fr, Stupniewski Adalbertus ${ }^{821}$, musicus, nat. 30.03.1739, prof. 10.06.1771 Gedani, obit. 13.01.1812 Klodaviae.

Michael à S. Augustino ARP ${ }^{822}$, ex prior, ex antiqua regularis observantia, nat. 1673, prof. 1698, obit. 09.04.1736 Oboriis.

Michael à S. Hieronimo RP ${ }^{823}$, nat. 1673, prof. 1698, obit. 27.12.1708 Posnaniae.

Michael à S. Joanne Baptista ARP, Sczepanski Joannes ${ }^{824}$, ex prior Kcynensis, nat. 01.06.1688, prof. 14.08.1714, obit. 16.03.1756 Drohobiciis.

Michael à S. Joanne Chojnacki RP ${ }^{825}$, nat. 1793, prof. 1825, presb. 1827, obit. 16.09.1859 Wąsosiae.

Michael à S. Joanne Fr, Winter Michael ${ }^{826}$, seniculus, hortulanus et ianitor, nat. 1688, prof. 14.11.1720, obit. 08.02.1768 Gedani.

${ }^{815}$ AKKr 174/614, s. 38; Kart. 27, s. 413; AKKr 175/547, s. 211; Zak. 66; Zak. 61, s. 105; Kroniczka, s. 40, 44, 55, 65 i 191-192: przeor klasztoru Bożego Ciała w Poznaniu w latach 1764-1766.

${ }^{816}$ AKKr 174/614, s. 33: podana data zgonu 12 marca 1755; AKKr 175/547, s. 623; Zak. 66; Zak. 61, s. 301.

${ }^{817}$ AKKr 174/614, s. 16-17; AKKr 175/547, s. 3; Zak. 66.

${ }^{818}$ AKKr 175/547, s. 653; Zak. 66.

${ }^{819}$ AKKr 174/614, s. 26-27; AKKr 175/547, s. 301; Zak. 66.

${ }^{820}$ AKKr 174/614, s. 14-15; AKKr 175/547, s. 565; Zak. 66; Zak. 61, s. 268: podana data zgonu 3 października 1795 .

${ }^{821}$ AKKr 174/614, s. 24-25; AKKr 175/547, s. 25.

${ }^{822}$ AKKr 175/547, s. 199; Zak. 66; Zak. 61, s. 95 i 104: podane daty zgonu 5 i 14 kwietnia 1736; Kroniczka, s. 14 i 189: przebywał w klasztorze Bożego Ciała w Poznaniu w 1724. Trzeci przełożony w rezydencji przy kościele Najświętszej Krwi Pana Jezusa w Poznaniu. Następnie ponownie w klasztorze Bożego Ciała.

${ }^{823}$ AKKr 175/547, s. 727; Zak. 66.

${ }^{824}$ AKKr 174/614, s. 33; Kart. 27, s. 408; AKKr 175/547, s. 151; Zak. 66; Zak. 61, s. 75.

${ }^{825}$ AKKr 175/547, s. 523; Zak. 66.

${ }^{826}$ AKKr 174/614, s. 37; Kart. 27, s. 415; AKKr 175/547, s. 77; Zak. 66; Zak. 61, s. 39; Zakonnicy, s. 335: podany tylko rok zgonu. 
Michael à S. Joanne RP, Szmerlinski Joannes ${ }^{827}$, ex concionator Polonorum, subprior loci, nat. 03.01.1740, prof. 08.11.1765, presb. 15.08.1770 Varsaviae, obit. 10.12.1806 Trutoviae.

Michael à S. Mathia ARP, Kąsinowski Mathias ${ }^{828}$, STL, bis ex provincialis, ex prior Markovicensis et Varsaviensis, praeses capituli, bis primitians, pluries definitor, cujus singulari cura idem conventus a fundamentis de novo est erectus, nat. 04.02.1712, prof. 29.09.1737 Posnaniae, presb. 08.09.1738 Bidgostiae, obit. 16.08.1796 Markovicae.

Michael à SS. Angelis RP ${ }^{829}$, nat. 1637, prof. 1658, obit. 12.09.1677 Bidgostiae.

Modestus à S. Basilio RP ${ }^{830}$, ex lector philosophiae, concionator Germanorum, nat. 1703, prof. 1724, obit. 30.04.1739 Gedani.

Modestus à S. Benedicto RP, Metzel Salomon ${ }^{831}$, nat. 20.07.1718, prof. 09.06.1740, presb. 1748, obit. 22.05.1763 Klodaviae.

Modestus à S. Joanne RP, Lurkowski Joannes ${ }^{832}$, nat. 16.02.1755, prof. 14.06.1772 Gedani, presb. 19.04.1778 Posnaniae, obit. 04.05.1801 Markovicae.

Narcissus à S. Adalberto RP, Brochocki Adalbertus ${ }^{833}$, nat. 13.04.1763, prof. 16.07.1781 Posnaniae, clericus discalceatus transiitae Oboriis.

Narcissus à S. Joanne RP Drążkowski Valentinus ${ }^{834}$, confesarius, nat. 1785, prof. 1814, presb. 1815, obit. 20.06.1871 Oboriis.

${ }^{827}$ AKKr 174/614, s. 10-11; AKKr 175/547, s. 693; Zak. 66: podana data zgonu 10 stycznia 1806 w Oborach; Zak. 61, s. 70 i 90: podane daty zgonu 11 i 31 marca 1808; ADP, C 54a, s. 70: członek konwentu w Bydgoszczy w 1767. Święcenia subdiakonatu otrzymał 19 września 1767 w Chełmży z rąk sufragana chełmińskiego Franciszka Fabiana Pląskowskiego.

${ }^{828}$ AKKr 174/614, s. 2-3; Kart. 27, s. 412: podana data urodzenia 11 września 1711; AKKr 175/547, s. 463: podana data zgonu 18 sierpnia 1796; Zak. 66; ADP, A 16, s. 59 i 60: członek konwentu w Bydgoszczy w 1738. Tonsurę i niższe święcenia otrzymał 10 sierpnia 1738, święcenia subdiakonatu 12 sierpnia 1738, diakonatu 15 sierpnia 1738 i prezbiteratu 17 sierpnia 1738 w Chełmży. Szafarzem wszystkich święceń był sufragan chełmiński Maciej Aleksander Sołtyk; Bibliografia Polska. t. 22, Stólecie XV-XVIII, cz. 3, T. 11 lit. M-My, przez K. Estreichera, Kraków 1908, s. 332: opublikował: Piana et plena instructio cantus choralis, anthoritate . . Prov. Carm. Gedani, typis Hartmannis 1756 w 8ce, str. 40 oraz Processionale juxta usum ordinis Fratrum Beatae Mariae Virginis de Monte Carmelo S. O. Provinciae Majoris Poloniae SS. Sacrameuti reductum. Officio defunctorura, et Synopsi merioriter cantatorum, auctum. Authoritate venerabilis Definitorii Oboriensis, recusum ac de mandato A. R. P. Michaelis a S. Mathia S. T. L. J. provincialis et definitoris generalis, typis expeditum anno salutis reparatae per Christum 1759. Varsaviae, typis S. R. M. Reipublicae in Collegio Regio Scholarum Piarum w 4ce, str. 109.

${ }^{829}$ AKKr 175/547, s. 515; Zak. 66; Zak. 61, s. 247.

${ }^{830}$ AKKr 175/547, s. 693; Zak. 66; Zak. 61, s. 120.

${ }^{831}$ AKKr 174/614, s. 36; Kart. 27, s. 413; AKKr 175/547, s. 353; Zak. 66; Zak. 61, s. 173: podana data zgonu 22 czerwca 1763 i pogrzebu 23 czerwca 1763; Zakonnicy, s. 335: podany tylko rok zgonu; Kloskowski, Sylwetki, s. 246: syn Jana i Magdaleny. Pochodził z Gdańska. W klasztorze dominikanów w Gdańsku zmarli jego dwaj bracia Anioł Piotr w 1755 i Benedykt w 1764. Jego brat Stanisław (1709-1729) był cystersą pelplińskim.

${ }^{832}$ AKKr 174/614, s. 12-13; Zak. 66; Zak. 61, s. 129: podana data zgonu 9 maja 1801.

${ }^{833}$ AKKr 174/614, s. 16-17.

${ }^{834}$ AKKr 175/547, s. 345; Informacje od p. Sławomira Kościelaka: podane imię zakonne Nazariusz. Urodził się w 1785 w miejscowości Turzenko koło Torunia. Do zakonu karmelitów wstąpił w 1811. Profesję zakonną złożył w 1812. Kaznodzieja polski w Gdańsku w latach 1817-1823. W 1823 przeszedł do klasztoru w Polsce. 
Narcissus à S. Josepho ARP, Domanski Josephus ${ }^{835}$, concionator laudabilis, ex prior Klodaviensis, ex subprior Lipiensis, actualis subprior loci, paralizo [sic] tactus, hac de causa grabatum eidem continuatum fuit per anos viginti, nat. 25.11.1765, prof. 11.03.1789 Posnaniae, presb. 1791, obit. 12.08.1839 Plonscii.

Narcissus à S. Josepho Fr, Guttman Josephus ${ }^{836}$, ex antiquae observantiae, terminarius bene commendatus, nat. 1734, prof. 21.11.1762 Cracoviae, obit. 25.08.1810 Trutoviae.

Narcissus à S. Zacharia RP, Wieczorkiewicz Petrus ${ }^{837}$, concionator Polonorum, nat. 02.07.1710, prof. 19.03.1727, obit. 05.12.1763 Trutoviae.

Nepomucenus à Conversione S. Pauli RP, Miller Joannes ${ }^{838}$, ex concionator Germanorum, organarius et vocalista, nat. 18.08 .1710 , prof. 30.06 .1733 , presb. 1735 , obit. 22.01.1770 Gedani.

Nepomucenus à S. Francisco RP, Pohl Franciscus ${ }^{839}$, nat. 06.10.1748, prof. 09.04.1771 Gedani, presb. 08.12.1771 Gedani, in provinciam Lituaniae, post saecularisatus.

Nepomucenus à S. Vincentio RP, Grenca Vincentius ${ }^{840}$, subprior loci, nat. 30.05.1772, prof. 1795, obit. 20.02.1810 Plonscii.

Nicolaus à Matre Dei RP ${ }^{841}$, nat. 1646, prof. 1665, obit. 21.06.1683 Gedani.

Nicolaus à S. Aloysio RP, Ostrowicki Alexander ${ }^{842}$, seniculus, nat. 05.03.1691, prof. 16.07.1716, obit. 10.11.1762 Lipiae.

Nicolaus à S. Ambrosio Fr, Bukiewicz Valentinus ${ }^{843}$, organarius, choralis, dispensator bene commendatus, nat. 07.12.1695, prof. 17.02.1717, obit. 30.11.1745 Bidgostiae.

Nicolaus à S. Antonio ARP, Thyla Antonius ${ }^{844}$, ex concionator Polonorum, syndicus provinciae, nat. 18.08.1746, prof. 14.06.1764 Gedani, presb. 25.12.1769 Posnaniae, obit. 16.03.1804 Plonscii.

Nicolaus à S. Bartholomaeo Fr, Sawicki Bartholomaeus ${ }^{845}$, braxator, nat. 24.08.1720, prof. 21.03.1754 Gedani, obit. 15.10.1799 Posnaniae.

${ }^{835}$ AKKr 174/614, s. 18-19; AKKr 175/547, s. 451; Zak. 66: podana data zgonu 14 sierpnia 1839; ADP, C 54a, s. 146: członek konwentu w Gdańsku w 1791. Święcenia diakonatu otrzymał 26 lipca 1791 i prezbiteratu 31 lipca 1791 w Oliwie z rąk sufragana chełmińskiego Iwona Onufrego Rogowskiego.

${ }^{836}$ AKKr 174/614, s. 24-25; AKKr 175/547, s. 475, 477 i 480: podana druga data zgonu 24 sierpnia 1810; Zak. 66

${ }^{837}$ AKKr 174/614, s. 36; Kart. 27, s. 410; AKKr 175/547, s. 683; Zak. 66; Zak. 61, s. 331.

${ }^{838}$ AKKr 174/614, s. 37; Kart. 27, s. 411; AKKr 175/547, s. 43; Zak. 66; Zak. 61, s. 22; Zakonnicy, s. 335: podany tylko rok zgonu; ADP, A 16, s. 39: członek konwentu w Oborach w 1735. Tonsurę i niższe święcenia otrzymał 27 września 1735, święcenia subdiakonatu 27 września 1735 , diakonatu 2 października 1735 w kościele parafialnym w Lubawie i prezbiteratu 4 października 1735 w kościele bernardynów w Lubawie. Szafarzem wszystkich święceń był sufragan chełmiński Maciej Aleksander Sołtyk.

${ }^{839}$ AKKr 174/614, s. 12-13.

${ }^{840} \mathrm{AKKr}$ 174/614, s. 20; Zak. 66: drugi zapis zgonu 13 marca 1810; AKKr 175/547, s. 105. Podana data zgonu 22 lutego 1810.

${ }^{841}$ AKKr 175/547, s. 347; Zak. 66; Zak. 61, s. 172.

${ }^{842}$ AKKr 174/614, s. 36; Kart. 27, s. 409.

${ }^{843} \mathrm{AKKr} 174 / 614$, s. 31 : podana data zgonu 29 listopada 1745; Kart. 27, s. 414; AKKr 175/547, s. 673; Zak. 66; Zak. 61, s. 325: podana data zgonu 29 listopada 1745.

${ }^{844} \mathrm{AKKr} 174 / 614$, s. 8-9; AKKr 175/547, s. 151; Zak. 66: podana data zgonu 8 kwietnia 1804; Zak. 61, s. 100: podana data zgonu 10 kwietnia 1804.

${ }^{845}$ AKKr 174/614, s. 22-23; AKKr 175/547, s. 581; Zak. 66; Zak. 61, s. 280. 
Nicolaus à S. Lucia ARP ${ }^{846}$, STL, jubilatus, vicarius provincialis, nat. 1677, prof. 1697, obit. 25.04.1724 Oboriis, immediate post Pascha ante Capitulum Provinciale.

Nicolaus à S. Ludvico $\mathrm{Fr}^{847}$, pannifex, nat. 1724, prof. 1746, obit. 16.07.1753 Posnaniae.

Nicolaus à S. Norberto RP ${ }^{848}$, nat. 1658, prof. 1678, obit. 23.01.1693 Bidgostiae.

Norbertus à S. Angelo ARP, Stroinski Albertus ${ }^{849}$, seniculus, ex prior Oboriis, nat. 12.04.1673, prof. 07.05.1690, obit. 04.01.1749 Plonscii.

Norbertus à S. Joanne Fr, Glowinski Joannes ${ }^{850}$, clericus perpetuus, nat. 02.01.1718, prof. 07.06.1759 Gedani, obit. 23.11.1775 Bidgostiae.

Norbertus à S. Josepho ARP, Szchur Josephus ${ }^{851}$, STL, ex definitor, provincialis actualis 6 mensium, nat. 21.04.1762, prof. 02.08.1778 Gedani, presb. 26.05.1785 Varsaviae, obit. 12.10.1805 Klodaviae.

Norbertus à S. Ludmilla ARP ${ }^{852}$, secretarius provinciae, nat. 1647, prof. 1664, obit. 16.01.1684 Bidgostiae.

Norbertus à S. Valentino ARP, Przybylinski Valentinus ${ }^{853}$, emeritus, concionator, secretarius provinciae, ex prior Plonscensis et Kcynensis, praesidens oratorii SSmi Sanguinis Christi, praefectus capellae, nat. 07.02.1707, prof. 19.06.1725, obit. 24.12.1762 Posnaniae.

Norbertus Kiszka $\mathrm{Fr}^{854}$, nondum professus, Conventui Guloviensi multum proficuus, obit. 01.06.1830 in Mienia.

Onuphrius à S. Anna ARP, Racięski Stanislaus ${ }^{855}$, ex prior Lipiensis, nat. 06.05.1721, prof. 08.08.1740 Gedani, presb. 20.07.1745 Kcynae, obit. 21.10.1807 Lipiae.

Onuphrius à S. Antonio ARP, Krolikowski Antonius ${ }^{856}$, concionator Polonorum, egregius ac emeritus, ex prior Oboriensis, ex definitor, ex magister novitiorum, prior loci,

${ }^{846}$ AKKr 175/547, s. 231; Zak. 66; Zak. 61, s. 115.

${ }^{847}$ AKKr 174/614, s. 33: podana data zgonu 7 lipca 1753; AKKr 175/547, s. 397; Zak. 66; Zak. 61, s. 195 i 197: podana druga data zgonu 14 lipca 1753.

${ }^{848}$ AKKr 175/547, s. 45; Zak. 66; Zak. 61, s. 23.

${ }^{849} \mathrm{AKKr} 174 / 614$, s. 32: zmarł 31 grudnia 1748 w miejscowości Galczau, został pochowany 4 stycznia 1749; Kart. 27, s. .407; AKKr 175/547 s. 7; Zak. 66: w rękopisie podane, że zmarł w Oborach; Zak. 61, s. 4.

${ }^{850}$ AKKr 174/614, s. 8-9 i 39; AKKr 175/547, s. 663: podana data zgonu 25 listopada 1775; Zak. 66; Zak. 61, s. 319 i 320: podana data zgonu 24 listopada 1775; ADP, C 54a, s. 70: członek konwentu w Bydgoszczy w 1767. Święcenia subdiakonatu otrzymał 19 września 1767 w Chełmży z rąk sufragana chełmińskiego Franciszka Fabiana Pląskowskiego; Mańkowski, Liber mortuorum, s. 65: konfrater cystersów koronowskich.

${ }^{851}$ AKKr 174/614, s. 14-15; AKKr 175/547, s. 575; Zak. 66; Zak. 61, s. 277.

${ }^{852}$ AKKr 175/54, s. 31; Zak. 66; Zak. 61, s. 16.

${ }^{853}$ AKKr 174/614, s. 36: podana data zgonu 19 listopada 1762; Kart. 27, s. 410; AKKr 175/547, s. 721; Zak. 66; Zak. 61, s. 320: podana data zgonu 24 listopada 1762; Kroniczka, s. 26 i 190: prezydent rezydencji przy kościele Najświętszej Krwi Pana Jezusa w Poznaniu w latach 1761-1762. Zmarł w rezydencji 24 listopada 1762.

${ }^{854}$ Zak. 66.

${ }^{855}$ AKKr 174/614, s. 4-5; Kart. 27, s. 413; AKKr 175/547, s. 593; Zak. 66; Zak. 61, s. 295: przekreślony zapis zgonu z datą 30 października 1807.

${ }^{856}$ AKKr 174/614, s. 16-17; AKKr 175/547, s. 189: podane miejsce zgonu Płońsk; Zak. 66: podana data zgonu 3 kwietnia 1822. 
nat. 21.06.1759, prof. 27.06.1779 Posnaniae, presb. 23.06.1782 Gedani, obit. 04.04.1822 Oboriis.

Onuphrius à S. Antonio Osinski RP ${ }^{857}$, definitor et custos provinciae, prior Varsaviensis, Wąsossensis et Klodaviensis, professor et lector theologiae moralis, cantor eximius, nat. 1814 , prof. 1832, presb. 1838, obit. 17.07.1871 Kalisbat.

Onuphrius à S. Josepho Fr, Wobb Josephus ${ }^{858}$, sartor, nat. 09.02.1734, prof. 11.09.1764 Gedani, obit. 31.12.1790 Oboriis.

Onuphrius ab Annut. B.M.V. Fr, Packowski Mathaeus ${ }^{859}$, bene meritus, terminarius, sartor, nat. 16.08.1705, prof. 10.04.1737, obit. 11.04.1763 Gedani.

Palladius à S. Francisco RP, Hoyer Franciscus ${ }^{860}$, ex concionator Germanorum, nat. 18.08.1760, prof. 13.12.1778 Gedani, presb. 16.06.1784 Posnaniae, obit. 28.09.1798 Kcynae.

Pantaleon à S. Joanne Baptista $\mathrm{RP}^{861}$, medicus, nat. 1703, prof. 1733, obit. 09.07.1737 Bidgostiae.

Paphnutius à S. Placido RP Neyman Ignatius ${ }^{862}$, musicus perfectus ac vocalista, nat. 19.11.1725, prof. 10.10.1744 Posnaniae, presb. 28.10.1748 Posnaniae, obit. 11.07.1797 Bidgostiae.

Paschalis à S. Thoma RP, Bienkowski Thomas ${ }^{863}$, nat. 22.12.1765, prof. Gedani, presb. 1789 Varsaviae.

Paschasius à S. Adalberto RP, Zurkowski Adalbertus ${ }^{864}$, nat. 09.04.1771.

Paschasius à S. Francisco $\mathrm{Fr}^{865}$, sutor, nat. 1721, prof. 1754, obit. 01.05.1772 Posnaniae.

Patritius à Dulcissimo Nomine Jezu RP, Zasiecki Nicolaus ${ }^{866}$, actualis subprior loci, nat. 05.12.1710, prof. 19.03.1727, obit. 28.02.1768 Oboriis.

Patritius à Passione Domini Fr ${ }^{867}$, clericus, nat. 1701, prof. 1718, obit. 24.07.1721 Bidgostiae.

${ }^{857}$ AKKr 175/547, s. 399 (zapis został do druku skrócony).

${ }^{858}$ AKKr 174/614, s. 24-25; AKKr 175/547, s. 735; Zak. 66.

${ }^{859}$ AKKr 174/614, s. 36; Kart. 27, s. 415; AKKr 175/547, s. 203; Zak. 66; Zak. 61, s. 101; Zakonnicy, s. 335.

${ }^{860}$ AKKr 174/614, s. 16-17; Zak. 66; Zak. 61, s. 263.

${ }^{861}$ AKKr 175/547, s. 383; Zak. 66; Zak. 61, s. 189 i 190: zapis z datą zgonu 8 lipca 1737 przekreślony.

${ }^{862}$ AKKr 174/614, s. 4-5; AKKr 175/547, s. 387; Zak. 66: podana data zgonu 11 sierpnia 1797; Zak. 61, s. 199: podana data zgonu 18 lipca 1797; Kroniczka, s. 36, 42, 69, 74, 77-78, 82 i 191: przybył do rezydencji przy kościele Najświętszej Krwi Pana Jezusa w Poznaniu w październiku 1764 z klasztoru w Markowicach. Głosił kazania w języku niemieckim. Od sierpnia do listopada 1766 przebywał w Czechach. Po powrocie odesłany do klasztoru Bożego Ciała w Poznaniu. W 1767 został skierowany na dwór w Posadowie.

${ }^{863}$ AKKr 174/614, s. 16-17; AAG, ACon G VI 11, s. 14v; Nowicki, Stownik biograficzny, s. 42: w 1799 był komendariuszem w Niedamowie. Zmarł 27 kwietnia 1820 jako komendariusz w Ostrowie w diecezji gnieźnieńskiej.

${ }^{864}$ AKKr 174/614, s. 20.

${ }^{865} \mathrm{AKKr} 174 / 614$, s. 38; AKKr 175/547, s. 247: podana data zgonu 3 maja 1772; Zak. 66: podana data zgonu 3 maja 1772; Zak. 61, s. 121.

${ }^{866}$ AKKr 174/614, s. 37; Kart. 27, s. 410; AKKr 175/547, s. 117; Zak. 66; Zak. 61, s. 59.

${ }^{867}$ AKKr 175/547, s. 413; Zak. 66; Zak. 61, s. 205. 
Patritius à S. Gregorio RP, Homan Joannes ${ }^{868}$, ex lector philosophiae, ex concionator Germanorum, eximius organarius, choralis, nat. 29.12.1705, prof. 12.03.1725, obit. 15.09.1748 Oboriis.

Patritius à S. Joanne Fr, Orłowski Joannes ${ }^{869}$, clericus, studens philosophiae, nat. 14.03.1753, prof. 10.03.1772 Gedani, obit. 28.01.1774 Bidgostiae.

Patritius à S. Michaele RP, Bakier Michael ${ }^{870}$, nat. 03.10.1756, prof. 14.03.1775 Gedani, presb. 26.04.1779 Plonscii, obit. 20.03.1803 Plonscii.

Paulinus à S. Alberto $\mathrm{Fr}^{871}$, nat. 1693, prof. 1717, obit. 08.10.1739 Posnaniae.

Paulinus à S. Eliseo $\mathrm{Fr}^{872}$, nat. 1660, prof. 1681, obit. 22.09.1709 Gedani.

Paulinus à S. Eliseo RP, Gorner Antonius ${ }^{873}$, musicus insignis, magister novitiorum, nat. 09.03.1732, prof. 29.06.1750 Posnaniae, presb. 06.04.1755 Posnaniae, obit. 20.04.1777 Posnaniae.

Paulinus à S. Francisco RP, Roszak Franciscus ${ }^{874}$, nat. 02.09.1748, prof. 02.08.1778 Gedani, in Provinciam S. Josephi iam Presbyter se transtulit.

Paulinus à S. Joanne RP, Ponka Joannes ${ }^{875}$, nat. 21.05.1768, prof. 02.08.1787 Gedani.

Paulinus à S. Josepho $\mathrm{Fr}^{876}$, nat. 1766, prof. 1784, obit. 08.09.1798 Markovicae.

Paulinus à S. Josepho $\mathrm{Fr}^{877}$, pannifex, nat. 1684, prof. 1744, obit. 18.09.1757 Posnaniae.

Paulinus à S. Laurentio $\mathrm{Fr}^{878}$, clericus, nat. 1688, prof. 1707, obit. 15.08.1710 Posnaniae.

Paulinus à S. Marco $\mathrm{Fr}^{879}$, nat. 1679, prof. 1700, obit. 24.08.1709 Bidgostiae.

Paulinus à S. Sebastiano $\mathrm{Fr}^{880}$, subdiaconus, nat. 1709, prof. 1726, obit. 30.03.1737 Plonscii.

Paulus à S. Cypriano RP ${ }^{881}$, nat. 1659, prof. 1690, obit. 24.08.1708 Posnaniae.

${ }^{868}$ AKKr 174/614, s. 32: podana data zgonu 14 września 1748; Kart. 27, s. 410; AKKr 175/547, s. 521; Zak. 66; Zak. 61, s. 250; Braniewo, s. 79 (wpis nr 1717): syn Tomasza i Katarzyny. Urodził się we Fromborku na Warmii. Od 1 września 1717 kształcił się w gimnazjum jezuickim w Braniewie.

${ }^{869}$ AKKr 174/614, s. 12-13 i 39; AKKr 175/547, s. 55; Zak. 66; Zak. 61, s. 28.

${ }^{870}$ AKKr 174/614, s. 14-15; 175/547, s. 159; Zak. 66: podana data zgonu 13 kwietnia 1803; Zak. 61, s. 100: podana data zgonu 10 kwietnia 1803.

${ }^{871}$ AKKr 175/547, s. 567; Zak. 66; Zak. 61, s. 286: podana data zgonu 21 października 1739 Markowice.

${ }^{872}$ AKKr 175/547, s. 535; Zak. 66; Zak. 61, s. 257.

${ }^{873}$ AKKr 174/614, s. 6-7 i 40: na s. 6-7 data zgonu 30 kwietnia 1777; AKKr 175/547, s. 229: podana data zgonu 24 kwietnia 1777; Zak. 66; Zak. 61, s. 110 i 114: przekreślony zapis z datą zgonu 24 kwietnia 1777.

${ }^{874}$ AKKr 174/614, s. 14-15.

${ }^{875}$ AKKr 174/614, s. 18-19.

${ }^{876}$ Zak. 66.

${ }^{877}$ AKKr 174/614, s. 34; AKKr 175/547, s. 529; Zak. 66; Zak. 61, s. 252: podana data zgonu 17 września 1757.

${ }^{878}$ AKKr 175/547, s. 457; Zak. 66.

${ }^{879}$ AKKr 175/547, s. 475; Zak. 66; Zak. 61, s. 228.

${ }^{880}$ AKKr 175/547, s. 179; Zak. 66; Zak. 61, s. 89.

${ }^{881}$ AKKr 175/547, s. 475; Zak. 66; Zak. 61, s. 228. 
Paulus à S. Cypriano RP ${ }^{882}$, studens theologiae, nat. 1675, prof. 1693, obit. 24.04.1700 Posnaniae.

Paulus à S. Floriano Fr, Ulinski (Mulinski) Petrus ${ }^{883}$, nat. 27.06.1713, prof. 20.05.1741 Gedani, obit. 21.12.1786 Lipiae.

Paulus à S. Francisco $\mathrm{Fr}^{884}$, clericus novitius, nat. 1691, obit. 20.07.1709 Posnaniae.

Paulus à S. Joanne Fr, Hanzolewicz Joannes ${ }^{885}$, multis annis in conventu Posnaniensi dispensator, sartor, bene commendatus, nat. 12.07.1766, prof. 02.09.1789 Posnaniae, obit. 14.04.1843 Kcynae.

Paulus à S. Martino RP, Czaykowski Martinus ${ }^{886}$, nat. 07.11.1747, prof. 04.02.1767 Posnaniae, presb. 08.12.1770 Gedani, obit. 07.05.1777 Oboriis.

Paulus à S. Petro Fr, Macinski Petrus ${ }^{887}$, braxator, nat. 29.06.1696, prof. 21.01.1744, obit. 31.05.1768 Plonscii.

Paulus à S. Petro RP ${ }^{888}$, nat. 1626, prof. 1645, obit. 13.11.1688 Posnaniae.

Paulus à S. Stanislao ARP, Filipski Stanislaus ${ }^{889}$, ex prior Markovicensis, nat. 11.05.1760, prof. 02.08.1778 Gedani, presb. 24.06.1783 Posnaniae, obit. 23.12.1803 Markovicae.

Paulus à S. Thoma ARP, Pagorselski Thomas ${ }^{890}$, STL, jubilatus, concionator Polonorum, definitor provinciae, professor rethorices, lector sacrorum canonum, ex prior Bidgostiensis, nat. 11.12.1689, prof. 28.03.1715, obit. 08.09.1764 Oboriis.

Petrus à S. Jacobo Fr, Konoth Jacobus ${ }^{891}$, nat. 09.07.1760, prof. 19.08.1786 Posnaniae, obit. 19.01.1823 Plonscii.

Petrus à $\mathrm{S}$. Paulo $\rightarrow$ Petrus à $\mathrm{S}$. Stanislao

Petrus à S. Stanislao Fr $^{892}$, nat. 1670, prof. 1693, obit. 17.10.1710 Bidgostiae.

Petrus à S. Stanislao RP, Szpotanski Stanislaus ${ }^{893}$, nat. 02.09.1749, prof. 16.09.1769 Posnaniae, presb. 01.11.1772 Bidgostiae, obit. 25.04.1790 Markovicae.

${ }^{882}$ AKKr 175/547, s. 229; Zak. 66: podany rok zgonu 1770; Zak. 61, s. 114; ADP, A 41, s. 11 i 12: członek konwentu w Gdańsku w 1694. Tonsurę i niższe święcenia otrzymał 5 czerwca 1694, święcenia subdiakonatu 18 grudnia 1694 w katedrze w Chełmży z rąk sufragana chełmińskiego Tomasza Skotnickiego.

${ }^{883}$ AKKr 174/614, s. 22-23; Kart. 27, s. 415; AKKr 175/547, s. 715; Zak. 66.

${ }^{884}$ AKKr 175/547, s. 405; Zak. 66; Zak. 61, s. 207: podana data zgonu 26 lipca 1709.

${ }^{885}$ AKKr 174/614, s. 28: Zak. 66.

${ }^{886}$ AKKr 174/614, s. 10-11 i 40; AKKr 175/547, s. 255; Zak. 66; Zak. 61, s. 127.

${ }^{887}$ AKKr 174/614, s. 37: podana data zgonu 30 maja 1768; Kart. 27, s. 416: błędnie wpisany rok urodzenia 1796; AKKr 175/547, s. 303; Zak. 66; Zak. 61, s. 150: podana data zgonu 30 maja 1768.

${ }^{888}$ AKKr 175/547, s. 639; Zak. 66; Zak. 61, s. 309.

${ }^{889}$ AKKr 174/614, s. 14-15; AKKr 175/547, s. 719; Zak. 66: podana data zgonu 27 grudnia 1803.

${ }^{890}$ AKKr 174/614, s. 36: podana data zgonu 7 września 1764; Kart. 27, s. 408; AKKr 175/547, s. 507; Zak. 66; Zak. 61, s. 243; Kroniczka, s. 23 i 190: przebywał w rezydencji przy kościele Najświętszej Krwi Pana Jezusa w Poznaniu między 1733, a 1751.

${ }^{891}$ AKKr 174/614, s. 28; Zak. 66; AKKr 175/547, s. 57: podana data zgonu 29 stycznia 1823.

${ }^{892}$ AKKr 175/547, s. 585; Zak. 66; Zak. 61, s. 291: podana data zgonu 26 października 1710 oraz imiona zakonne Petrus à S. Paulo.

${ }^{893}$ AKKr 174/614, s. 12-13; AKKr 175/547, s. 231; Zak. 66; Zak. 61, s. 114: podana data zgonu 24 kwietnia 1790; ADP, C 54a, s. 84 i 85: członek konwentu w Bydgoszczy w 1772. Tonsurę i niższe święcenia otrzymał 2 sierpnia 1772, święcenia subdiakonatu 10 sierpnia 1772, diakonatu 16 sierpnia 
Petrus à S. Teresia RP, Truszczynski Joannes ${ }^{894}$, ex concionator emeritus, ex subprior Oboriensis, Posnaniensis et actualis loci, nat. 28.01.1712, prof. 15.10.1734 Gedani, presb. 08.09.1741 Gedani, obit. 22.12.1780 Trutoviae.

Petrus à S. Valentino $\mathrm{Fr}^{895}$, nat. 1727, prof. 1747, obit. 20.03.1767 Drohobiciis exsolvit jura mortalitatis.

Petrus à Salvatore Mundi RP ${ }^{896}$, nat. 1637, prof. 1656, obit. 22.07.1686 Bidgostiae.

Petrus Thomas à S. Agnete RP, Kosmowski Nicolaus ${ }^{897}$, concionator Polonorum, nat. 08.12.1696, prof. 29.01.1715, obit. 20.09.1754 Kcynae.

Petrus Thomas à S. Leonardo RP ${ }^{898}$, professor rethorices et philosophiae, nat. 1697, prof. 1714, obit. 04.06.1731 Oboriis.

Petrus Thomas à S. Maria Magdalena de Pazzis RP ${ }^{899}$, nat. 1649, prof. 1668, obit. 12.06.1708 Posnaniae.

Petrus Thomas à S. Martino ARP, Mikowski (Mykowski) Martinus ${ }^{900}$, ex definitor et custos Provinciae, ex magister novitiorum, ex prior loci, ex subprior Gedanensis et Posnanensis, subprior loci, in vinea Christi et regularis observantiae zelator tum praedicando, tum audiendo fidelium confessiones, nat. 19.11.1755, prof. 07.10.1772 Gedani, presb. 19.04.1778 Posnaniae, obit. 19.08.1826 Klodaviae.

Petrus Thomas Ochlewski ARP ${ }^{901}$, ex prior Oboriis, nat. 1812, obit. 02.01.1879 Osiek.

Philibertus à S. Marco ARP, Piper Laurentius ${ }^{902}$, STL, pluribus annis magister novitiorum, bis ex definitor, subprior loci, nat. 20.01.1726, prof. 21.09.1745 Gedani, presb. 06.01.1752 Posnaniae, obit. 20.08.1802 Varsaviae.

Philibertus à S. Valentino Jaworski $\mathrm{ARP}^{903}$, ex secretarius, ex definitor ac ex regens provinciae, concionator, actualis subprior Trutoviensis, nat. 1800, prof. 1816, presb. 1824 , obit. 24.12.1845 in villa Zbójno, sepultus Trutoviae.

Philippus à S. Francisco RP ${ }^{904}$, cantor, choralis eximius, subprior loci, nat. 1705, prof. 1723, obit. 15.12.1736 Drohobiciis.

Philippus à S. Jacobo $\rightarrow$ Philippus à S. Josepho

1772 i prezbiteratu 11 października 1772 w Chełmży. Szafarzem wszystkich święceń był sufragan chełmiński Franciszek Fabian Pląskowski.

${ }^{894}$ AKKr 174/614, s. 2-3 i 41; Kart. 27, s. 412: data urodzenia 28 stycznia 1714; AKKr 175/547, s. 717 ; Zak. 66.

${ }^{895}$ AKKr 174/614, s. 37; AKKr 175/547, s. 159; Zak. 66; Zak. 61, s. 79.

${ }^{896}$ AKKr 175/547, s. 409; Zak. 66; Zak. 61, s. 201: podana data zgonu 20 lipca 1686.

${ }^{897}$ Kart. 27, s. 408; AKKr 175/547, s. 531; Zak. 66; Zak. 61, s. 239: podana data zgonu 4 września 1754.

${ }^{898}$ AKKr 175/547, s. 311; Zak. 66; Zak. 61, s. 155.

${ }^{899}$ AKKr 175/547, s. 327; Zak. 66; Zak. 61, s. 162: podana data zgonu 11 czerwca 1708 Bydgoszcz.

${ }^{900}$ AKKr 174/614, s. 12-13; AKKr 175/547, s. 465; Zak. 66; ADWł, ABKP. Wiz. nr 43(90), k.3v-4, 304, 318v: kapelan i wikariusz w Drzycimiu w 1780, był wtedy członkiem konwentu w Bydgoszczy.

${ }^{901}$ AKKr 175/547, s. 3: zmarł jako administrator parafii Osiek.

${ }^{902}$ AKKr 174/614, s. 4-5; AKKr 175/547, s. 467; Zak. 66; Zak. 61, s. 224.

${ }^{903}$ AKKr 175/547, s. 721; Zak. 66: podana data zgonu 25 grudnia 1845.

${ }^{904}$ AKKr 175/547, s. 703; Zak. 66; Zak. 61, s. 340. 
Philippus à S. Jacobo Fr, Kraska Jacobus ${ }^{905}$, nat. 23.01.1724, prof. 05.08.1765 Gedani, obit. 17.06.1795 Bidgostiae.

Philippus à S. Joanne Baptista $\rightarrow$ Philippus à S. Josepho

Philippus à S. Joanne Baptista RP, Rync Hyacinthus ${ }^{906}$, nat. 24.08.1728, prof. 16.02.1745 Gedani, presb. 20.07.1752 Gedani, obit. 27.08.1786 Markovicae.

Philippus à S. Josepho Fr, Hartel Godefridus ${ }^{907}$, nat. 18.02.1699, prof. 03.05.1720.

Philippus à S. Josepho $\mathrm{Fr}^{908}$, terminarius, nat. 1709, prof. 1731, obit. 26.01.1762 Lipiae.

Philippus Rutkowski Fr ${ }^{909}$, quaestiarius, nat. 1772, obit. 10.02.1832 Klodaviae.

Placidus à Nativitate B.M.V. Fr ${ }^{910}$, obit. 25.02.1741 Klodaviae.

Placidus à S. Francisco $\mathrm{Fr}^{911}$, nat. 1662, prof. 1683, obit. 15.11.1704 Posnaniae.

Placidus à S. Joanne Baptista $\mathrm{Fr}^{912}$, nat. 1672, prof. 1705, obit. 19.03.1741 Klodaviae.

Placidus à S. Michaele RP, Teichert Adalbertus ${ }^{913}$, musicus et vocalista, actualis director novitiorum, nat. 01.04.1723, prof. 17.10.1743, obit. 25.02.1759 Posnaniae.

Placidus à S. Thoma ARP, Karolewski Thomas ${ }^{914}$, concionator, ex prior Oboriensis, nat. 28.01.1747, prof. 23.12.1775 Gedani, presb. 10.08.1777 Plonscii, obit. 27.03.1804 in capellania et sepultus Przodkoviae.

Polykarpus à S. Petro ARP, Sankowski Petrus ${ }^{915}$, STL, bis ex provincialis, ex praeses capituli, ex secretarius et definitor provinciae, in prioratu Kcynensi interpolatim complevit annos 13, nat. 09.08.1739, prof. 01.03.1756 Posnaniae, presb. 26.11.1762 Varsaviae, obit. 20.08.1800 Kcynae.

Polykarpus Owsiany RP ${ }^{916}$, ex concionator Lipiensis et Plonscensis, capellanus in Wielgie, nat. 1787, prof. 1814, presb. 1815, obit. 22.09.1829 in Wielgie.

Processus à S. Antonio $\mathrm{Fr}^{917}$, sartor, nat. 1756, prof. 1797, obit. 10.01.1808 Kcynae.

${ }^{905}$ AKKr 174/614, s. 24-25; AKKr 175/547, s. 339; Zak. 66: podana data zgonu 27 czerwca 1795; Zak. 61, s. 168: podane miejsce zgonu Markowice; Mańkowski, Liber mortuorum, s. 113: konfrater cystersów koronowskich.

${ }^{906}$ AKKr 174/614, s. 4-5: podana data zgonu 24 września 1773; AKKr 175/547, s. 483; Zak. 66; Zak. 61, s. 231.

${ }^{907}$ Kart. 27, s. 414.

${ }^{908}$ AKKr 174/614, s. 35; AKKr 175/547, s. 27; Zak. 66; Zak. 61, s. 14: podana data zgonu 14 stycznia 1762 oraz imiona zakonne Philippus à S. Jacobo; Zak. 61, s. 29: podana data zgonu 29 stycznia 1762 oraz imiona zakonne Philippus à S. Joanne Baptista.

${ }^{909}$ Zak. 66; AKKr 175/547, s. 99: data zgonu 19 lutego 1832.

${ }^{910}$ Zak. 61, s. 56.

${ }^{911}$ AKKr 175/547, s. 643; Zak. 66; Zak. 61, s. 311 i 105: podana data zgonu 15 kwietnia 1704.

${ }^{912}$ AKKr 175/547, s. 157; Zak. 66.

${ }^{913}$ AKKr 174/614, s. 34; Kart. 27, s. 414; AKKr 175/547, s. 111; Zak. 66; Zak. 61, s. 56.

${ }^{914}$ AKKr 174/614, s. 14-15; AKKr 175/547, s. 173: podane, że zmarł w Gdańsku; Zak. 66; Zak. 61, s. 86; ADP, C 54a, s. 126; Zakonnicy, s. 336: członek konwentu w Gdańsku w 1776. Tonsurę i niższe święcenia otrzymał 1 maja 1776 w kościele św. Wojciecha pod Gdańskiem, subdiakonatu 1 czerwca 1776 w kościele karmelitów w Gdańsku i diakonatu 24 sierpnia 1776 w kościele św. Wojciecha pod Gdańskiem z rąk sufragana chełmińskiego Franciszka Fabiana Pląskowskiego.

${ }^{915}$ AKKr 174/614, s. 6-7; AKKr 175/547, s. 467; Zak. 66; Zak. 61, s. 232: podana data zgonu 28 sierpnia 1800.

${ }^{916}$ AKKr 175/547, s. 535; Zak. 66.

${ }^{917}$ AKKr 175/547, s. 19. 
Processus à S. Josepho $\mathrm{Fr}^{918}$, obit. 10.05.1808 Lipiae.

Processus à S. Simone $\mathrm{Fr}^{919}$, nat. 1761, prof. 1785, obit. 05.02.1808 Kcynae.

Processus à S. Visitatione B.M.V. Fr, Tokarski Michael ${ }^{920}$, musicus egregius, nat. 12.09.1712, prof. 20.05.1739, obit. 25.01.1763 Kcynae.

Prothasius à S. Joanne Nepomuceno $\mathrm{Fr}^{921}$, clericus, studens theologiae, nat. 1720, prof. 1739, obit. 01.01.1742 Gedani.

Prothasius à S. Thaddaeo $\mathrm{Fr}^{922}$, clericus, nat. 1757, prof. 1777, obit. 11.08.1779 Oboriis.

Quintinus à S. Antonio RP, Hibner Antonius ${ }^{923}$, musicus, sexennalis magister novitiorum, bis primitians, subprior loci, nat. 12.12.1720, prof. 28.11.1742 Gedani, presb. 20.07.1745 Posnaniae, obit. 12.10.1797 Gedani.

Quirinus à S. Daciano Fr, Matszulkie (Matszydkie) Stanislaus ${ }^{924}$, quaestiarius, nat. 04.05.1704, prof. 04.06.1731 Gedani, obit. 07.01.1781 Gedani. dani.

Quirinus à S. Davidi Fr, Otręmbka David ${ }^{925}$, nat. 06.09.1761, prof. 25.10.1784 Ge-

Raphael à S. Hieronymus RP, Boczenski Paulus ${ }^{926}$, subprior loci, nat. 31.01.1706, prof. 01.10.1724, obit. 05.08.1756 Plonscii.

Raphael à S. Joanne RP, Schonse Joannes ${ }^{927}, 10$ annis magister novitiorum, concionator, emeritus, nat. 10.09.1743, prof. 26.10.1762 Gedani, presb. 09.11.1766 Bidgostiae, obit. 22.10.1810 Posnaniae.

Raymundus à Nativitate B.V.M. ARP ${ }^{928}$, ex concionator Polonorum, actualis prior loci, nat. 1677, prof. 1698, obit. 13.07.1715 Kcynae.

${ }^{918}$ Zak. 61, s. 130.

${ }^{919}$ AKKr 175/547, s. 71; Zak. 66

${ }^{920} \mathrm{AKKr}$ 174/614, s. 36: podana data zgonu 15 stycznia 1763; Kart. 27, s. 415; AKKr 175/547, s. 49; Zak. 66; Zak. 61, s. 25.

${ }^{921}$ AKKr 174/614, s. 31; AKKr 175/547, s. 1; Zak. 61, s. 1; Zakonnicy, s. 334: podany rok urodzenia 1721.

${ }^{922}$ AKKr 174/614, s. 40; AKKr 175/547, s. 429; Zak. 66; Zak. 61, s. 213: podana data zgonu 1 sierpnia 1779.

${ }^{923}$ AKKr 174/614, s. 4-5; Kart. 27, s. 413; AKKr 175/547, s. 575; Zak. 66; Zak. 61, s. 277; Zakonnicy, s. 336: podany tylko rok zgonu.

${ }^{924}$ AKKr 174/614, s. $22-23$ i 41; Kart. 27, s. 415; AKKr 175/547, s. 13; Zak. 66; Zak. 61, s. 7; Zakonnicy, s. 336; Kroniczka, s. 24 i 190: kwestarz w rezydencji przy kościele Najświętszej Krwi Pana Jezusa w Poznaniu między 1751, a 1757.

${ }^{925}$ AKKr 174/614, s. 26-27.

${ }^{926}$ AKKr 174/614, s. 34: podana data zgonu 20 sierpnia 1758; Kart. 27, s. 410; AKKr 175/547, s. 437; Zak. 66; Zak. 61, s. 214: podana data zgonu 2 sierpnia 1756; AAG, ACap B 79, s. 46: członek konwentu w Markowicach w 1726. Tonsurę i niższe święcenia otrzymał 28 października 1726 w kościele parafialnym w Kamieńcu z rąk sufragana gnieźnieńskiego Franciszka Kraszkowskiego.

${ }^{927}$ AKKr 174/614, s. 8-9; AKKr 175/547, s. 595; Zak. 66; ADP, C 54a, s. 64, 65 i 67: członek konwentu w Bydgoszczy w 1766. Tonsurę i niższe święcenia otrzymał 22 lutego 1766, święcenia subdiakonatu 15 marca 1766, diakonatu 19 marca 1766 i prezbiteratu 19 października 1766 w Chełmży. Szafarzem wszystkich święceń był sufragan chełmiński Franciszek Fabian Pląskowski.

${ }_{928}$ AKKr 175/547, s. 391; Zak. 66; Zak. 61, s. 194 i 196: podana druga data zgonu 15 lipca 1696. 
Raymundus à S. Athanasio ARP, Kocer Daniel ${ }^{929}$, organarius, choralis, secretarius et definitor provinciae, actualis prior Klodaviensis, nat. 01.08.1695, prof. 14.05.1717, obit. 21.11.1746 Thorunii sub manu medici, sepultus Klodaviae 26.11.1746.

Raymundus à S. Casimiro RP, Kostrzynski (Kostrzycki) Casimirus ${ }^{930}$, subprior loci, nat. 09.03.1736, prof. 02.10.1759 Posnaniae, presb. 08.04.1764 Gnesnae, obit. 01.11.1804 Klodaviae.

Raymundus à S. Ignatio Fr, Nicinski Ignatius ${ }^{931}$, nat. 03.02.1760, prof. 25.10.1784 Gedani.

Reginaldus à S. Alberto RP, Szweykowski Valentinus ${ }^{932}$, actualis concionator Polonorum Gedanensis, itinerans Gedanum in villa Dąmbrowka, tribus milliaribus a Posnania distante, decessit, inde corpus eius reductum una cum R.P. Ferdinando (de quo heri), fratre suo germano, sepultum, nat. 14.02.1722, prof. 27.08.1743, obit. 13.05.1761 Posnaniae.

Remigius à S. Josepho RP, Wyganowski Stanislaus ${ }^{933}$, nat. 17.12.1716, prof. 14.03.1735 Posnaniae, presb. 12.07.1742 Posnaniae.

Remigius à SS. Angelis RP, Komorowski Jacobus ${ }^{934}$, seniculus, nat. 30.06.1693, prof. 25.11.1716, obit. 02.02.1763 Drohobiciis.

Richardus à S. Andrea RP, Sielski Andreas ${ }^{935}$, STL, nat. 29.11.1744, prof. 15.06.1761 Gedani, presb. 08.05.1768 Posnaniae, obit. 15.06.1801 Plonscii.

Richardus Lazarowicz ARP ${ }^{936}$, antiquae regularis observantiae, paralizo [sic] tactus, hac de causa grabatum ei adiunctum fuit usque ad cosummationem vitae, ex prior loci, nat. 1750, prof. 1770, obit. 29.07.1826 Vąsosiae.

Robertus à S. Francisco RP, Hennig Franciscus ${ }^{937}$, nat. 06.07.1699, prof. 29.09.1718, obit. 29.11.1746 Oboriis.

Robertus à S. Gasparo Fr, Grzelakowski Gaspar938, nat. 19.01.1737, prof. 08.08.1764 Posnaniae, obit. 04.09.1796 Klodaviae.

${ }^{929}$ AKKr 174/614, s. 31; Kart. 27, s. 409; AKKr 175/547, s. 655; Zak. 66; Zak. 61, s. 317 (zapis został do druku skrócony) i 322: podana data zgonu 26 listopada 1746.

${ }^{930}$ AKKr 174/614, s. 8-9; AKKr 175/547, s. 615; Zak. 66: podana data zgonu 1 września 1804; Zak. 61, s. 236: podana data zgonu 1 września 1804; ADWł, ABSWł 10, s. 12: członek konwentu w Bydgoszczy w 1761. Tonsurę i niższe święcenia otrzymał 28 października $1761 \mathrm{w}$ kościele klarysek w Bydgoszczy z rąk sufragana włocławskiego Jana Dembowskiego.

${ }_{931}$ AKKr 174/614, s. 26-27.

${ }^{932}$ AKKr 174/614, s. 35: podane miejsce zgonu Dąmbrowka; Kart. 27, s. 414; AKKr 175/547, s. 267; Zak. 66; Zak. 61, s. 133.

${ }^{933}$ AKKr 174/614, s. 2-3; Kart. 27, s. 412: podana data urodzenia 17 października 1716 i złożenia profesji zakonnej 19 marca 1735.

${ }^{934}$ AKKr 174/614, s. 36; Kart. 27, s. 409; AKKr 175/547, s. 65; Zak. 66; Zak. 61, s. 33.

${ }^{935}$ AKKr 174/614, s. 8-9; AKKr 175/547, s. 345: podana data zgonu 20 czerwca 1801; Zak. 66; Zak. 61, s. 201: podana data zgonu 20 lipca 1801; Kroniczka, s. 90, 139, 141 i 196: w 1767 przebywał w klasztorze Bożego Ciała w Poznaniu. W rezydencji przy kościele Najświętszej Krwi Pana Jezusa w Poznaniu krótko w maju i czerwcu 1768.

${ }^{936}$ Zak. 66.

${ }^{937}$ AKKr 174/614, s. 31; Kart. 27, s. 409; Zak. 61, s. 324: podana data zgonu 28 listopada 1746.

${ }^{938}$ AKKr 174/614, s. 24-25; AKKr 175/547, s. 499; Zak. 61, s. 269. 
Robertus à S. Valentino RP, Marszałkowski Valentinus ${ }^{939}$, nat. 11.02.1762, prof. 08.06.1779 Gedani, presb. 03.04.1785 Posnaniae, obit. 15.01.1822 Lipiae.

Rochus à S. Francisco Fr, Bork (Borch) Franciscus ${ }^{940}$, terminarius, nat. 30.09.1761, prof. 21.11.1782 Gedani, obit. 23.01.1813 Bidgostiae.

Rochus à S. Josepho RP, Rogalla Josephus ${ }^{941}$, exorcista, nat. 09.03.1737, prof. 27.08.1768 Gedani, presb. 12.10.1770 Kcynae, obit. 20.04.1776 Markovicae.

Rochus à S. Michaele RP ${ }^{942}$, sacrista, nat. 1732, prof. 1753, obit. 03.04.1767 Oboriis.

Rochus à S. Simone Fr, Slewinski Simon ${ }^{943}$, sartor, nat. 09.10.1731, prof. 10.08.1758 Gedani, obit. 30.12.1778 Klodaviae.

Rochus à S. Valentino RP, Staniszewski Valentinus ${ }^{944}$, nat. 02.02.1758, prof. 12.07.1777 Gedani, presb. 19.03.1782 Varsaviae.

Rochus Zdziarski RP ${ }^{945}$, in exilium relegatus ibidem obiit, obit. 30.05 .

Romaeus à Nativitate B.M.V. $\rightarrow$ Romaeus à Nativitate Domini

Romaeus à Nativitate Domini Fr, Szmurlenski Andreas ${ }^{946}$, nat. 04.12.1696, prof. 1725, obit. 11.06.1756 Klodaviae.

Romaeus à S. Nicolao RP, Nerman Nicolaus ${ }^{947}$, nat. 29.10.1750, prof. 24.08.1769 Gedani, obit. 05.01.1798 Varsaviae.

Romanus à S. Bartholomaeo RP ${ }^{948}$, studens theologiae, nat. 1714, prof. 1732, obit. 15.06.1738 Varsaviae.

Romualdus à S. Dorothea RP ${ }^{949}$, concionator Polonorum, nat. 1685, prof. 1704, obit. 21.12.1719 Oboriis.

Romualdus à S. Michaele Fr, Jerowski Michael ${ }^{950}$, exemplaris et activus, nat. 10.09.1706, prof. 07.03.1741, obit. 19.05.1762 Gedani.

${ }^{939}$ AKKr 174/614, s. 16-17; AKKr 175/547, s. 29 i 121: podana również data zgonu 1 marca 1822; Zak. 66: podana data zgonu 8 stycznia 1822.

${ }^{940}$ AKKr 174/614, s. 26-27; AKKr 175/547, s. 323: podana data zgonu 10 czerwca 1813; Zak. 66.

${ }^{941}$ AKKr 174/614, s. 10-11 i 39: na s. 39 podana data zgonu 22 kwietnia 1776; AKKr 175/547, s. 223: podana data zgonu 21 kwietnia 1776; Zak. 66: podana data zgonu 20 maja 1776; Za. 61, s. 110.

${ }^{942}$ AKKr 174/614, s. 37; AKKr 175/547, s. 695; Zak. 66; Zak. 61, s. 93 i 334: podana data zgonu 9 grudnia 1767.

${ }^{943}$ AKKr 174/614, s. $24-25$ i 40; AKKr 175/547, s. 733; Zak. 66: podana data zgonu 29 grudnia 1778.

${ }^{944}$ AKKr 174/614, s. 14-15.

${ }^{945}$ AKKr 175/547, s. 301: brak miejsca i roku zgonu.

${ }^{946}$ AKKr 174/614, s. 33: podana data zgonu 6 marca 1756; Kart. 27, s. 415: brak pełnej daty złożenia profesji zakonnej; AKKr 175/547, s. 325 i 621: podana również druga data zgonu 4 listopada 1746; Zak. 66: podana druga data zgonu 4 listopada 1746; Zak. 61, s. 65, 161 i 300: podane daty zgonu 6 marca 1756 i 4 listopada 1746.

${ }^{947}$ AKKr 174/614, s. 10-11; Zak. 66; Zak. 61, s. 5.

${ }^{948}$ AKKr 175/547, s. 335; Zak. 66; Zak. 61, s. 166.

${ }^{949}$ AKKr 175/547, s. 715; Zak. 66; ADP, A 41, s. 27: członek konwentu w Gdańsku w 1707. Tonsurę i niższe święcenia otrzymał 24 września 1707 w katedrze w Chełmży z rąk sufragana chełmińskiego Seweryna Szczuki.

${ }^{950} \mathrm{AKKr}$ 174/614, s. 36: podana data zgonu 18 maja 1762; Kart. 27, s. 415; AKKr 175/547, s. 279; Zak. 66; Zak. 61, s. 138: podana data zgonu 18 maja 1762; Zakonnicy, s. 335: podana data 
Romualdus à S. Simone Fr, Patucki Simon ${ }^{951}$, nat. 12.10.1745, prof. 06.02.1770 Gedani, obit. 21.02.1802 Oboriis.

Romualdus à S. Simone RP, Suczynski Stephanus ${ }^{952}$, nat. 03.08.1722, prof. 06.02.1743 Posnaniae, presb. 20.07.1746 Varsaviae, obit. 18.01.1793 Lipiae.

Romualdus Fromski Fr ${ }^{953}$, bene meritus, nat. 1774, prof. 1811, obit. 26.12.1841 Oboriis.

Rudolphus à S. Augustino ARP, Fischer Augustinus ${ }^{954}$, STL, ex definitor, ex prior Lipiensis, nat. 18.09.1726, prof. 24.04.1744 Gedani, presb. 01.01.1750 Varsaviae, obit. 20.09.1791 Bidgostiae.

Salesius à S. Adamo RP, Gagalski Adamus ${ }^{955}$, nat. 30.08.1749, prof. 26.11.1770 Posnaniae, presb. 13.06.1773 Gedani, obit. 04.02.1789 Drohobiciis.

Samuel à S. Joanne ARP, Stolinski Joannes ${ }^{956}$, concionator Germanorum, ex magister novitiorum, prior loci, nat. 05.05.1760, prof. 13.12.1778 Gedani, presb. 19.06.1783 Varsaviae, obit. 13.01.1798 Gedani.

Sebaldus à S. Michaele RP, Waldowski Michael ${ }^{957}$, nat. 09.05.1764, prof. 27.07.1780 Gedani, presb. 08.06.1787 Posnaniae, obit. 04.09.1808 Trutoviae.

Sebastianus à Desponsatione B.M.V. RP, Michałowski Carolus ${ }^{958}$, ex concionator Polonorum, subprior loci, nat. 04.11.1715, prof. 25.01.1739, obit. 22.12.1758 Kcynae.

Sebastianus à S. Adalberto RP, Menia Adalbertus ${ }^{959}$, nat. 16.04.1769, prof. 1789, obit. 06.08.1797 Lipiae.

Sebastianus à S. Andrea $\mathrm{RP}^{960}$, nat. 1673, prof. 1693, obit. 14.03.1710 Varsaviae.

Sebastianus à S. Joanne Evangelista ARP ${ }^{961}$, STL, prior loci, nat. 1694, prof. 1713, obit. 11.03.1731 Gedani.

zgonu 18 maja 1762.

${ }^{951}$ AKKr 174/614, s. 24-25; AKKr 175/547, s. 103; Zak. 66; Zak. 61, s. 52.

${ }_{952}$ AKKr 174/614, s. 4-5; Kart. 27, s. 413; AKKr 175/547, s. 35; Zak. 66; Zak. 61, s. 18.

${ }^{953}$ AKKr 175/547, s. 725; Zak. 66.

${ }^{954}$ AKKr 174/614, s. 4-5; Kart. 27, s. 414; AKKr 175/547, s. 531; Zak. 66: podana data zgonu 28 września 1791; Zak. 61, s. 256: podana data zgonu 21 września 1791; ADP, Parafia Pruszcz Tucholski, W 1217, chrzty 1756-1776, s. 47v: kapelan domowy w Kamienicy w 1776 u Jakuba Lipińskiego notariusza województwa pomorskiego; Kroniczka, s. 40 i 192: definitor prowincji w 1766; Mańkowski, Liber mortuorum, s. 104: podana data zgonu 22 września 1791. Konfrater cystersów koronowskich.

${ }^{955}$ AKKr 174/614, s. 12-13; AKKr 175/547, s. 7 i 69: podana druga data zgonu 4 stycznia 1789; Zak. 66; Zak. 61, s. 35; ADP, C 54a, s. 86 i 87: członek konwentu w Oborach w 1773. Tonsurę i niższe święcenia oraz bierzmowanie otrzymał 21 marca 1773, święcenia subdiakonatu 27 marca 1773 i diakonatu 1 maja 1773 w Chełmży z rąk sufragana chełmińskiego Franciszka Fabiana Pląskowskiego.

${ }_{956}$ AKKr 174/614, s. 16-17; AKKr 175/547, s. 25; Zak. 66; Zak. 61, s. 13; Zakonnicy, s. 336.

${ }^{957}$ AKKr 174/614, s. 16-17; AKKr 175/547, s. 499; Zak. 66; Zak. 61, s. 239.

${ }^{958}$ AKKr 174/614, s. 34; Kart. 27, s. 412; AKKr 175/547, s. 717; Zak. 66; ADP, A 16, s. 70 i 71 : członek konwentu w Bydgoszczy w 1740. Święcenia subdiakonatu otrzymał 21 września 1740 i diakonatu 24 września 1740 w Chełmży z rąk sufragana chełmińskiego Macieja Aleksandra Sołtyka.

${ }^{959}$ AKKr 174/614, s. 20; AKKr 175/547, s. 521: podana data zgonu 15 września 1796; Zak. 66; Zak. 61, s. 238: podana data zgonu 3 września 1797.

${ }^{960}$ AKKr 175/547, s. 147 i 283: drugi zapis zgonu z datą 21 maja 1706; Zak. 66: drugi zapis zgonu z datą 21 maja 1706; Zak. 61, s. 73 i 141: drugi zapis zgonu z datą 21 maja 1710.

${ }^{961}$ AKKr 175/547, s. 141; Zak. 66; Zak. 61, s. 70; Zakonnicy, s. 333: podany tylko rok zgonu. 
Sebastianus à S. Joanne RP, Dzięcielski Joannes ${ }^{962}$, nat. 26.06.1746, prof. 22.12.1766 Gedani, presb. 14.06.1770 Gedani, obiit in Provincia Minoris Poloniae.

Sebastianus à S. Maria Fr, Brzeczkowski Michael ${ }^{963}$, nat. 06.05.1720, prof. 10.1744

Seraphinus à Regina Angelorum RP ${ }^{964}$, STL, jubilatus, nat. 1667, prof. 1685. obit. 19.01.1705 Bidgostiae.

Seraphinus à S. Andrea ARP, Pilawski Andreas ${ }^{965}$, jubilatus, concionator Polonorum, ex prior Markovicensis, ex definitor, actualis secretarius provinciae, nat. 23.11.1704, prof. 24.11.1720, obit. 04.02.1758 Oboriis.

Seraphinus à S. Augustino RP, Theyler Augustinus ${ }^{966}$, nat. 24.02.1734, prof. 22.02.1759 Posnaniae, presb. 19.07.1762 Bidgostiae, obit. 22.01.1785 Kcynae.

Seraphinus à S. Josepho ARP, Gloza Josephus ${ }^{967}$, ex prior Klodaviensis, ex definitor provinciae, actualis prior loci, nat. 24.08.1768, prof. 18.02.1786 Gedani, presb. 02.10.1791 Plonscii, obit. 23.11.1823 Kcynae.

Seraphinus à S. Josepho RP ${ }^{968}$, obit. 09.01.1791 Plonscii.

Seraphinus Kilanowski ARP ${ }^{969}$, pluribus annis concionator Klodaviensis et Varsaviensis, actualis secretarius provinciae et vicarius, prior loci, nat. 1829, prof. 1851, presb. 1854, obit. 10.11.1864 Guloviae.

Serapion à S. Andrea Fr, Szczechowski Andreas ${ }^{970}$, musicus, nat. 29.11.1733, prof. 13.07.1765 Posnaniae, obit. 20.03.1808 Plonscii.

Serapion à S. Andrea RP ${ }^{971}$, nat. 1730, prof. 1753, obit. 07.05.1766 Gedani.

${ }^{962}$ AKKr 174/614, s. 10-11: w rękopisie brak daty i miejsca zgonu.

${ }^{963}$ Kart. 27, s. 416: brak daty dziennej złożenia profesji zakonnej.

${ }^{964}$ AKKr 175/547, s. 99; Zak. 66; Zak. 61, s. 50; ADP, A 41, s. 6: członek konwentu w Gdańsku w 1691. Święcenia prezbiteratu otrzymał 9 czerwca 1691 w katedrze w Chełmży z rąk sufragana chełmińskiego Tomasza Skotnickiego; Kroniczka, s. 6 i 188: lektor św. teologii w klasztorze Bożego Ciała w Poznaniu w 1702.

${ }^{965}$ AKKr 174/614, s. 34; Kart. 27, s. 409; AKKr 175/547, s. 69; Zak. 66; Zak. 61, s. 33 i 35: podana druga data zgonu 2 lutego 1758; AAG, ACap B 79, s. 53: członek konwentu w Kcyni w 1728. Święcenia prezbiteratu otrzymał 11 stycznia 1728 w kaplicy seminaryjnej w Gnieźnie z rąk sufragana gnieźnieńskiego Franciszka Kraszkowskiego.

${ }^{966}$ AKKr 174/614, s. 6-7; AKKr 175/547, s. 43; Zak. 66; ADWł, ABSWł 10, s. 12, 15 i 17: członek konwentu w Bydgoszczy w latach 1761-1762. Tonsurę i niższe święcenia otrzymał 28 października 1761 w kościele klarysek w Bydgoszczy, święcenia subdiakonatu 4 marca 1762, diakonatu 6 marca 1762 i prezbiteratu 12 czerwca 1762 we Włocławku. Szafarzem wszyskich święceń był sufragan włocławski Jan Dembowski.

${ }^{967}$ AKKr 174/614, s. 18-19; AKKr 175/547, s. 659 i 665: wpis na s. 659 przekreślony, a na s. 665 podana data zgonu 26 listopada 1823; Zak. 66; AAG, ACon G VI 11, s. 16: data zgonu nie została podana.

${ }^{968}$ AKKr 174/614, s. 42; Zawadzki, s. 376: w latach 1762-1763 był duszpasterzem w Tychnowach w części pomezańskiej diecezji chełmińskiej.

${ }^{969}$ AKKr 175/547, s. 633; Zak. 66.

${ }^{970}$ AKKr 174/614, s. 24-25; AKKr 175/547, s. 159.

${ }^{971}$ AKKr 174/614, s. 36; AKKr 175/547, s. 255; Zak. 66; Zak. 61, s. 127; Zakonnicy, s. 335: podany tylko rok zgonu. 
Serapion à S. Brunone RP, Knorr Antonius ${ }^{972}$, pictor, nat. 28.01.1689, prof. 16.10.1712, obit. 17.12.1750 Kcynae.

Serapion à S. Dionysio Fr, Witkowski Martinus ${ }^{973}$, clericus perpetuus, musicus, nat. 11.11.1679, prof. 1723, obit. 14.05.1751 Kcynae.

Serapion à S. Jacobo RP, Dąbrowski Jacobus ${ }^{974}$, nat. 01.05.1744, prof. 04.11.1768 Gedani, presb. 29.03.1772 Klodaviae, obit. in Provincia Russiae.

Serapion à S. Josepho RP ${ }^{975}$, nat. 1669, prof. 1688, obit. 14.10.1709 Gedani.

Serapion à S. Simone $\mathrm{Fr}^{976}$, nat. 1634, prof. 1655, obit. 02.06.1675 Posnaniae.

Serapion à S. Theodoro RP, Schmitt Theodorus ${ }^{977}$, clericus, studens theologiae, nat. 09.11.1772, prof. 1791, obit. 23.12.1797 Posnaniae.

Serapion à S. Theresia $\mathrm{ARP}^{978}, \mathrm{STL}$, jubilatus, ex vicarius privincialis, ex prior Bidgostiensis et Posnaniensis, etiam in lingua hebraica eruditus, actualis prior loci, nat. 1652, prof. 1671, obit. 03.09.1707 Drohobiciis.

Serenus à S. Jacobo ARP, Augustynowicz Jacobus ${ }^{979}$, ex prior Markovicensis, nat. 15.07.1762, prof. 02.04.1780 Gedani, presb. 29.09.1785 Posnaniae, obit. 14.02.1813 Markovicae.

Severinus à S. Josepho RP, Popławski Josephus ${ }^{980}$, nat. 18.10.1743, prof. 26.10.1762 Gedani, presb. 03.05.1773 Kcynae, obit. 25.10.1777 Markovicae.

Sigismundus à S. Casimiro $\mathrm{Fr}^{981}$, nat. 1663, prof. 1687, obit. 14.12.1716 Oboriis.

Sigismundus à S. Casimiro $\mathrm{Fr}^{982}$, nat. 1694, prof. 1714, obit. 12.02.1744 Posnaniae.

Sigismundus à S. Martino RP, Szirller (Sztiller, Schtüler) Martinus ${ }^{983}$, subprior loci, nat. 20.02.1748, prof. 29.11.1769 Posnaniae, presb. 26.12.1771 Gedani, obit. 21.10.1822 Varsaviae.

Sigismundus à S. Stanislao $\mathrm{Fr}^{984}$, nat. 1692, prof. 1714, obit. 26.04.1722 Oboriis.

Sigismundus à S. Valentino RP, Borowski Valentinus ${ }^{985}$, seniculus, nat. 27.01.1684, prof. 13.04.1719, obit. 11.05.1755 Trutoviae.

Silvester à S. Hyacintho Fr, Narwinski Hyacinthus ${ }^{986}$, terminarius, quaestuarius, nat. 16.08.1739, prof. 31.12.1771 Gedani, obit. 03.10.1793 Lipiae.

${ }_{972}$ AKKr 174/614, s. 32: podana data zgonu 18 listopada 1750; Kart. 27, s. 408; AKKr 175/547, s. 707; Zak. 66.

${ }^{973}$ AKKr 174/614, s. 32: podana data zgonu 10 maja 1751; Kart. 27, s. 414; AKKr 175/547, s. 269; Zak. 66; Zak. 61, s. 134.

${ }^{974}$ AKKr 174/614, s. 10-11.

${ }^{975} \mathrm{AKKr}$ 175/547, s. 579; Zak. 66: podana data zgonu 13 października $1709 \mathrm{w}$ Warszawie; Zak. 61, s. 279.

${ }^{976}$ AKKr 175/547, s. 307; Zak. 66; Zak. 61, s. 153.

${ }^{977}$ AKKr 174/614, s. 20; Zak. 66.

${ }^{978}$ AKKr 175/547, s. 497; Zak. 66; Zak. 61, s. 237: podana data zgonu 2 września 1707; Kroniczka, s. 6 i 188: przebywał w klasztorze Bożego Ciała w 1687. Wiceprowincjał w 1702.

${ }^{979}$ AKKr 174/614, s. 16-17; AKKr 175/547, s. 89; Zak. 66.

${ }^{980}$ AKKr 174/614, s. 8-9 i 40; AKKr 175/547, s. 601; Zak. 66; Zak. 61, s. 290.

${ }^{981}$ AKKr 175/547, s. 701; Zak. 66; Zak. 61, s. 339.

${ }^{982}$ AKKr 175/547, s. 85; Zak. 66; Zak. 61, s. 43.

${ }^{983}$ AKKr 174/614, s. 12-13; AKKr 175/547, s. 593: nazwisko w formie Schtüler; Zak. 66: podana data zgonu 29 listopada 1821 oraz nazwisko w formie Sztiller.

${ }^{984} \mathrm{AKKr}$ 175/547, s. 233; Zak. 66; Zak. 61, s. 117: podana data zgonu 27 kwietnia 1722.

${ }^{985}$ AKKr 174/614, s. 33; Kart. 27, s. 409; AKKr 175/547, s. 263; Zak. 66; Zak. 61, s. 131.

${ }^{986}$ AKKr 174/614, s. 24-25; AKKr 175/547, s. 557; Zak. 66; Zak. 61, s. 268. 
Silvester à S. Joanne Evangelista Fr, Sczypalski Franciscus ${ }^{987}$, nat. 28.01.1714, prof. 30.12.1742, obit. 22.01.1761 Posnaniae, in capella Sanguinis Christi.

Silvester à S. Joanne $\mathrm{Fr}^{988}$, nat. 1670, prof. 1691, obit. 01.08.1706 Posnaniae.

Silvester à S. Paulo RP, Marcinkiewicz Paulus ${ }^{989}$, nat. 03.06.1763, prof. 23.12.1779 Gedani, deus scit querad obiit.

Silvester Konopka $\mathrm{Fr}^{990}$, quaestarius, nat. 1841, prof. 1861, obit. 06.06.1920 Oboriis.

Simeon à S. Joanne RP, Preuss Joannes ${ }^{991}$, capellanus in Pszczewo, nat. 03.04.1763, prof. 23.12.1779 Gedani, presb. 19.08.1787 Gedani, obit. 27.05.1796 et sepultus Pszczeviae.

Simon à Monte Carmeli RP ${ }^{992}$, nat. 1661, prof. 1682, obit. 29.07.1710 Posnaniae.

Simon à S. Adalberto $\mathrm{Fr}^{993}$, nat. 1634, prof. 1657, obit. 12.10.1684 Posnaniae.

Simon à S. Alberto $\mathrm{Fr}^{994}$, pictor, nat. 1640, prof. 1663, obit. 18.11.1685 Bidgostiae.

Simon à S. Antonio ARP ${ }^{995}$, STL, ex professor theologiae et philosophiae, ex secretarius provinciae, concionator eximius, selectae eiusdem conciones polonicae sub titulo "Diarii Concionatorii" in folio prodierunt in lucem publicam. Tandem prior Gedanensis. Sed infirmae valetudinis. Itinerans ad medicum Jastrovecensem, obiit, nat. 1694, prof. 1715, sepultus 16.07.1740 Bidgostiae.

Simon à S. Jacobo RP, Gorski (Lewald Gorski, Gurski) Jacobus ${ }^{996}$, nat. 24.07.1759, prof. 23.07.1781 Gedani, presb. 31.07.1785 Gedani, obit. 26.10.1818 Gedani.

Simon à S. Joanne Fr, Buszewski Joannes ${ }^{997}$, nat. 21.10.1741, prof. 08.05.1769 Gedani, obit. 05.10.1808 Trutoviae.

Simon à S. Josepho $\mathrm{Fr}^{998}$, pictor, obit. 29.06.1684 Bidgostiae.

${ }^{987}$ AKKr 174/614, s. 35; Kart. 27, s. 416; AKKr 175/547, s. 43; Zak. 66; Zak. 61, s. 22.

${ }^{988}$ AKKr 175/547, s. 429; Zak. 66; Zak. 61, s. 213.

${ }^{989}$ AKKr 174/614, s. 16-17.

${ }^{990}$ AKKr $175 / 547$, s. 315.

${ }^{991}$ AKKr 174/614, s. 16-17; AKKr 175/547, s. 295; Zak. 66; Zak. 61, s. 155: podana data zgonu 4 czerwca 1796.

${ }^{992}$ AKKr 175/547, s. 423; Zak. 66; Zak. 61, s. 210.

${ }^{993}$ AKKr 175/547, s. 575; Zak. 66; Zak. 61, s. 277.

${ }^{994}$ AKKr 175/547, s. 649; Zak. 66; Zak. 61, s. 314.

${ }^{995}$ AKKr 175/547, s. 397; Zak. 66; Zak. 61, s. 197; Kroniczka, s. 200: kaznodzieja w klasztorze Bożego Ciała w Poznaniu w 1724 i 1727; Zakonnicy, s. 334: podany tylko rok zgonu; Mańkowski, Dzieje drukarstwa, s. 146: po jego śmierci wydrukowano: Dyaryusz Odświętnego Roku Kaznodzieyskiego należyta pilnościa wyrachowany Chrześciańskim pobożnościom z Ambony zalecony albo Kazania Roczne Na Uroczystości Świętych Pańskich przez W. X. Szymona od S. Antoniego Karmelitę Sciśleyszey Obserwancyi Prowincyi Wielko Polskiey przed tym Kaznodzieya potym Konwentu Gdańskiego Przeora. W rożnych Kościołach miane po Smierci jego zebrane Dla Zachęcenia affektow Chrzesciańskich ku SS. Pańskim do Druku podane Roku 1751 w Gdańsku Drukowat Tomasz Jan Schreiber szlachetnego Magistratu y stawnego Gimnazyum Drukarz. 31 X 20 cm. Str. 498. (Bibl. pobernardyńska w Świeciu.)

${ }_{996}$ AKKr 174/614, s. 16-17; AKKr 175/547, s. 603; Zak. 66; Zakonnicy, s. 337: podany rok urodzenia 1757, rok złożenia profesji 1779, święceń prezbiteratu 1784 i zgonu 1816.

${ }^{997}$ AKKr 174/614, s. 24-25; Zak. 66; Zak. 61, s. 271: podana data zgonu 6 października 1808.

${ }^{998}$ Zak. 61, s. 180. 
Simon à S. Mathia Fr, Wolki Mathias ${ }^{999}$, seniculus, sartor ac terminarius bene meritus, nat. 14.02.1691, prof. 17.05.1712, obit. 07.11.1764 Bidgostiae.

Simon à S. Nicolao Lipiński RP ${ }^{1000}$, nat. 1821, obit. 19.01.1876 Oboriis.

Simon à S. Norberto ARP, Winiecki Josephus ${ }^{1001}$, ex concionator Polonorum, subprior, ex prior Trutoviensis, prior loci, nat. 27.08.1720, prof. 26.06.1742 Posnaniae, presb. 21.09.1745 Posnaniae, obit. 10.03.1780 Lipiae.

Spiridion à S. Casimiro ARP ${ }^{1002}$, concionator insignis, ex prior Oboriensis, nat. 1681, prof. 1716, obit. 02.12.1736 Trutoviae.

Spiridion à S. Francisco $\rightarrow$ Spiridion ab Immaculata Conceptione B.M.V.

Spiridion à S. Marco Fr ${ }^{1003}$, clericus, nat. 1657, prof. 1679, obit. 30.03.1680 Posnaniae.

Spiridion à S. Maria Magdalena de Pazzis RP ${ }^{1004}$, subprior loci, nat. 1665, prof. 1681, obit. 10.08.1731 Plonscii.

Spiridion ab Immaculata Conceptione B.M.V. RP, Lukaszewicz Bartholomaeus $^{1005}$, nat. 30.08.1718, prof. 03.01.1740 Posnaniae, presb. 01.11.1745 Plonscii, obit. 09.05.1792 Lipiae.

Stanislaus à S. Adalberto Makowski RP ${ }^{1006}$, nat. 1801, prof. 1824, presb. 1830, obit. 15.03.1844 Lipiae.

Stanislaus à S. Alberto $\mathrm{ARP}^{1007}$, ex prior loci, nat. 1661, prof. 1681, obit. 15.01.1710 Gedani.

Stanislaus à S. Antonio $\mathrm{Fr}^{1008}$, clericus novitius, obit. 19.10.1710 Gedani.

Stanislaus à S. Dorothea ARP, Frankiewicz Franciscus ${ }^{1009}$, ex prior Plonscensis, Kcynensis et Markovicensis, actualis prior loci, nat. 07.10.1697, prof. 01.10.1715, obit. 11.02.1758 Lipiae.

Stanislaus à S. Ignatio $\mathrm{Fr}^{1010}$, clericus, nat. 1687, prof. 1705, obit. 16.11.1709 Gedani.

${ }^{999}$ AKKr 174/614, s. 36: podana data zgonu 7 grudnia 1764; Kart. 27, s. 414; AKKr 175/547, s. 627; Zak. 66.

${ }^{1000}$ AKKr 175/547, s. 37.

${ }^{1001}$ AKKr 174/614, s. 4-5 i 41; Kart. 27, s. 413: podana data urodzenia 23 marca 1720; AKKr 175/547, s. 139; Zak. 66; Zak. 61, s. 69; Kroniczka, s. 161 i 200: mistrz nowicjatu w klsztorze Bożego Ciała w Poznaniu w 1769.

${ }^{1002}$ AKKr 175/547, s. 677; Zak. 66; Zak. 61, s. 328: podana data zgonu 2 grudnia 1737.

${ }^{1003}$ AKKr 175/547, s. 179; Zak. 66; Zak. 61, s. 89.

${ }^{1004}$ AKKr 175/547, s. 447; Zak. 66; Zak. 61, s. 222.

${ }^{1005} \mathrm{AKKr}$ 174/614, s. 2-3: podane imiona zakonne Spiridion à S. Francisco; Kart. 27, s. 413. podana data urodzenia 31 sierpnia 1718 i złożenia profesji 30 stycznia 1740; AKKr 175/547, s. 259.; Zak. 66; Zak. 61, s. 129.

${ }^{1006}$ AKKr 175/547, s. 149; Zak. 66.

${ }^{1007}$ AKKr 175/547, s. 29; Zak. 66; Zak. 61, s. 15; ADP, G 20a, s. 20v: Stanisław od św. Wojciecha Sowiński był proboszczem w Chmielnie w 1686.

${ }^{1008}$ Zak. 61, s. 284.

${ }^{1009}$ AKKr 174/614, s. 34; Kart. 27, s. 408; AKKr 175/547, s. 83; Zak. 66; Zak. 61, s. 42; Kroniczka, s. 14 i 189: podprzeor w klasztorze Bożego Ciała w Poznaniu w 1727. Rezydent w rezydencji przy kościele Najświętszej Krwi Pana Jezusa w Poznaniu.

${ }^{1010} \mathrm{AKKr}$ 175/547, s. 473 i 645: podana druga data zgonu 23 sierpnia 1711; Zak. 66: podana druga data zgonu 23 sierpnia 1711; Zak. 61, s. 312 i 227: podana data zgonu 23 sierpnia 1711. 
Stanislaus à S. Jacobo $\mathrm{Fr}^{1011}$, nat. 1658, prof. 1681, obit. 11.08.1692 Gedani.

Stanislaus à S. Michaele Fr, Garulewski Joannes ${ }^{1012}$, seniculus morigeratus ac oeconomus bene meritus, nat. 01.01.1690, prof. 01.05.1711, obit. 20.05.1766 Kcynae.

Stanislaus à S. Paulo Małachowski RP ${ }^{1013}$, profesor et procurator, nat. 1839, prof. 1859, presb. 1863, obit. 10.01.1895 Oboriis.

Stanislaus à S. Petro RP, Wylma Petrus ${ }^{1014}$, subprior loci, nat. 01.09.1745, prof. 16.06.1763 Gedani, presb. 16.04.1770 Klodaviae, obit. 20.01.1799 Bidgostiae.

Stanislaus à S. Spiritu RP ${ }^{1015}$, concionator, nat. 1663, prof. 1685, obit. 03.12.1739 Bidgostiae.

Stanislaus à S. Teresia ARP, Opalinski Joannes ${ }^{1016}$, in Provincia nostra Austriaca 30 annorum professus, ad instantiam Illustrissimi Domini Caroli Comitis in Bnin Opalenski, germani eiusdem fratris, Reverendissimo Patre Ordinis nostri Generali annuente, affiliatus nostrae Provinciae. 20 annorum intervallo definitoris, praesidis Capituli, bis prioris Posnaniensis, postremo in Oratorio praesidentis officio exercuit. Actualis presidens capellae Sanguinis Christi, nat. 20.06.1690, prof. 21.09.1711, obit. 24.03.1761 Posnaniae.

Stanislaus Walczak ARP ${ }^{1017}$, ex prior Cracoviensis et Sąsiadovice, et novissime cooperator in Conventu in Wola Gułowska, egregius contionator tempore belli, ab anno 1914 ad 1918 capelanus militum; morbus renum obitum causavit, nat. 1882, prof. 1903, obit. 12.09.1929 Cracoviae.

Stephanus à Nativitate Domini $\mathrm{Fr}^{1018}$, nat. 1648, prof. 1668, obit. 14.02.1685 Oboriis.

Stephanus à Purificat B.V.M. RP ${ }^{1019}$, concionator Polonorum, nat. 1693, prof. 1710, obit. 02.08.1730 Bidgostiae.

Stephanus à S. Alberto ARP, Sebastyanski Bartholomaeus ${ }^{1020}$, STL, ex prior Gedanensis, Oboriensis et Posnaniensis, actualis praesidens ad capellam Sanguinis Christi, nat. 23.08.1715, prof. 12.08.1736 Posnaniae, presb. 16.10.1740 Varsaviae, obit. 04.02.1799 Posnaniae.

${ }^{1011}$ AKKr 175/547, s. 449; Zak. 66; Zak. 61, s. 218: podana data zgonu 6 sierpnia 1692 Chojnice.

${ }^{1012}$ AKKr 174/614, s. 36; Kart. 27, s. 414; AKKr 175/547, s. 281; Zak. 66; Zak. 61, s. 140.

${ }^{1013}$ AKKr 175/547, s. 19.

${ }^{1014}$ AKKr 174/614, s. 8-9; Zak. 66; Zak. 61, s. 20; ADWł, ABSWł 10, s. 43: syn Piotra. Z archidiecezji gnieźnieńskiej. Członek konwentu w Kłodawie w 1770. Święcenia diakonatu otrzymał 10 marca 1770 i prezbiteratu 31 marca 1770 we Włocławku z rąk sufragana włocławskiego Jana Dembowskiego; Mańkowski, Liber mortuorum, s. 122: konfrater cystersów koronowskich.

${ }^{1015}$ AKKr 175/547, s. 679; Zak. 66; Zak. 61, s. 329 i 103: podana data zgonu 13 kwietnia 1709.

${ }^{1016}$ AKKr 174/614, s. 35; Kart. 27, s. 408; AKKr 175/547, s. 167; Zak. 66; Zak. 61, s. 83; Kroniczka, s. 25 i 190: przeor klasztoru Bożego Ciała w Poznaniu w latach 1742-1743. Prezydent rezydencji przy kościele Najświętszej Krwi Pana Jezusa w Poznaniu w latach 1757-1761. Zmarł w rezydencji. Krewny starosty śremskiego Jana Franciszka Opalińskiego.

${ }^{1017}$ AKKr 175/547, s. 515.

${ }^{1018}$ AKKr 175/547, s. 89; Zak. 66.

${ }^{1019}$ AKKr 175/547, s. 431; Zak. 66; Zak. 61, s. 214; Zakonnicy, s. 333: podany tylko rok zgonu i miejsce Gdańsk.

${ }^{1020}$ AKKr 174/614, s. 2-3; Kart. 27, s. 412; Zak. 66; Zak. 61, s. 63: podana data zgonu 4 marca 1799; Kroniczka, s. VII, 28, 29, 30, 32, 34, 44, 53, 56, 64, 66, 67, 69, 120, 165, 172, 180 i 190: lektor teologii i definitor prowincji. Prezydent rezydencji przy kościele Najświętszej Krwi Pana Jazusa w Poznaniu w latach 1763-1766, przeor w Oborach i ponownie prezydent rezydencji w 1769. 
Stephanus à S. Alberto ARP ${ }^{1021}$, tertio ex vicarius provincialis, nat. 1662, prof. 1681, obit. 06.07.1727 Oboriis.

Stephanus à S. Anastasio RP ${ }^{1022}$, procurator, obit. 12.05.1771 Varsaviae in capellania.

Stephanus à S. Joanne Fr, Niewiecki Joannes ${ }^{1023}$, organarius eximius, nat. 30.08.1756, prof. 02.09.1789 Posnaniae, presb. 1806, obit. 08.04.1820 Varsaviae.

Stephanus à S. Thoma Fr, Brokhoff Antonius ${ }^{1024}$, prof. 01.01.1753 Posnaniae, obit. Silesia.

Sylverius à S. Andrea $\mathrm{Fr}^{1025}$, clericus, studens philosophiae, nat. 1738, prof. 1756, obit. 20.08.1760 Gedani.

Sylverius à S. Andrea RP, Koperszmytt Andreas ${ }^{1026}$, nat. 26.11.1764, prof. 02.08.1787 Gedani, obit. 20.04.1796 Kcynae.

Thaddaeus à Matre Dei Fr ${ }^{1027}$, nat. 1644, prof. 1665, obit. 27.06.1684 Posnaniae.

Thaddaeus à S. Clemento Fr, Zbitkiewicz Clemens ${ }^{1028}$, nat. 16.11.1759, prof. 21.11.1782 Gedani, ejectus in cerrigibilis.

Thaddaeus à S. Joanne Evangelista RP, Lorentz Joannes ${ }^{1029}$, pictor, nat. 29.10.1706, prof. 01.11.1724, obit. 20.06.1764 Kcynae.

Thaddaeus à S. Joanne Fr, Hahn Joannes ${ }^{1030}$, seniculus, sartor, dispensator, nat. 1699, prof. 03.06.1722, obit. 12.07.1767 Klodaviae.

Thaddaeus à S. Joanne RP, Jaworski Joannes ${ }^{1031}$, nat. 22.05.1746, prof. 18.10.1768 Gedani, presb. 08.09.1772 Gedani.

Thaddaeus à S. Josepho Fr, Felhner Josephus ${ }^{1032}$, exemplaris multis annis huius conventus prudens dispensator, nat. 1767, prof.18.10.1789 Posnaniae, obit. 23.04.1824 Klodaviae.

Thelesphorus à S. Joanne Baptista RP ${ }^{1033}$, nat. 1681, prof. 1699, obit. 21.08.1710 Posnaniae.

${ }^{1021}$ AKKr 175/547, s. 377; Zak. 66; Zak. 61, s. 187; Kroniczka, s. 8, 10, 11, 12,13 i 14 i 189: lektor teologii i definitor prowincji. Przeor klasztoru Bożego Ciała w Poznaniu w 1704.

${ }^{1022}$ AKKr 174/614, s. 38; Zak. 61, s. 132.

${ }^{1023}$ AKKr 174/614, s. 28; AKKr 175/547 s. 197 i 257: podana na s. 257 data zgonu 8 maja 1820; Zak. 66.

${ }^{1024} \mathrm{AKKr} 174 / 614$, s. 22-23: w rękopisie brak daty urodzenia oraz daty i miejsca zgonu.

${ }^{1025}$ AKKr 174/614, s. 35: podana data zgonu 21 sierpnia 1760; AKKr 175/547, s. 467; Zak. 66;

Zak. 61, s. 224; Zakonnicy, s. 335: podany tylko rok zgonu i imię Sylvericus.

${ }^{1026}$ AKKr 174/614, s. 18-19; AKKr 175/547, s. 221; Zak. 66; Zak. 61, s. 110.

${ }^{1027}$ AKKr 175/547, s. 359; Zak. 66; Zak. 61, s. 177: podana data zgonu 26 czerwca 1684.

${ }^{1028}$ AKKr 174/614, s. 26-27.

${ }^{1029}$ AKKr 174/614, s. 36: podana data zgonu 19 czerwca 1764; Kart. 27, s. 410; AKKr 175/547, s. 345; Zak. 66; Zak. 61, s. 170: podana data zgonu 19 czerwca 1764.

${ }^{1030} \mathrm{AKKr} 174 / 614$, s. 37: podana data zgonu 7 lipca 1767; Kart. 27, s. 415: brak pełnej daty urodzenia; AKKr 175/547, s. 389; Zak. 66; Zak. 61, s. 188 i 193: podana druga data zgonu 7 lipca 1767.

${ }^{1031}$ AKKr 174/614, s. 10-11.

${ }^{1032}$ AKKr 174/614, s. 28; AKKr 175/547, s. 287; Zak. 66: podana data zgonu 20 września 1824.

${ }^{1033}$ AKKr 175/547, s. 469; Zak. 66; Zak. 61, s. 225. 
Thelesphorus à S. Josepho RP, Cicherski Joannes ${ }^{1034}$, terminarius, nat. 02.04.1722, prof. 11.10.1740, obit. 10.11.1762 Markovicae.

Thelesphorus à S. Josepho $\mathrm{RP}^{1035}$, nat. 1644, prof. 1661, obit. 02.03.1684 Oboriis.

Thelesphorus à S. Mathaeo $\mathrm{RP}^{1036}$, procurator loci, nat. 1700, prof. 1720, obit. 28.03.1739 Gedani.

Thelesphorus à S. Teresia ARP ${ }^{1037}$, ex vicarius provincialis, obit. 20.02.1690 Posnaniae.

Thelesphorus à S. Valentino RP, Woycicki Valentinus ${ }^{1038}$, nat. 19.02.1748, prof. 05.12.1764 Posnaniae, presb. 25.03.1772 Posnaniae.

Thelesphorus à Venerabili Sacramento $\mathrm{Fr}^{1039}$, clericus, nat. 1693, prof. 1711, obit. 28.01.1716 Bidgostiae.

Thelesphorus à Venerabili Sacramento $\mathrm{RP}^{1040}$, nat. 1698, prof. 1716, obit. 02.06.1734 Drohobiciis.

Theodoricus à S. Petro RP, Neullen Petrus ${ }^{1041}$, nat. 28.06.1765, prof. 28.11.1783 Posnaniae, non est.

Theodorus à Matre Dei $\mathrm{Fr}^{1042}$, obit. 07.10.1684 Posnaniae.

Theodorus à S. Antonio Vomberg RP ${ }^{1043}$, nat. 1785, prof. 1804, presb. 1809, obit. 15.05.1813 Gedani, obiit et sepultus in capelania in villa Giemlic.

Theodorus à S. Caecilia ARP, Szumicki Antonius ${ }^{1044}$, concionator Polonorum, seniculus, jubilatus et emeritus, ex prior Posnaniensis, Kcynensis, Klodaviensis et Bidgostiensis, ac vicarius Trutoviensis, nat. 01.06.1699, prof. 28.11.1716, presb. 1723, obit. 13.12.1772 in capellania Illustrissimi Dembowski vexilliferi in Liberadz, sepultus 19.12.1772 Plonscii.

Theodorus à S. Jacobo Fr, Kłossowski Jacobus ${ }^{1045}$, quaestiarius, terminarius, nat. 06.05.1715, prof. 28.11.1741, obit. 03.11.1749 Klodaviae.

Theodorus à S. Joanne Fr, Metz Joannes ${ }^{1046}$, sartor exemplaris, nat. 21.10.1749, prof. 12.11.1770 Gedani, obit. 20.09.1808 Klodaviae.

${ }^{1034}$ AKKr 174/614, s. 36: podana data zgonu 19 listopada 1762; Kart. 27, s. 413; AKKr 175/547, s. 633; Zak. 66; Zak. 61, s. 306 i 335: podana data zgonu 10 grudnia 1762.

${ }^{1035}$ AKKr 175/547, s. 123; Zak. 66; Zak. 61, s. 61.

${ }^{1036}$ AKKr 175/547, s. 175; Zak. 66; Zak. 61, s. 86: podana data zgonu 27 marca 1739.

${ }^{1037}$ AKKr 175/547, s. 101; Zak. 66; Zak. 61, s. 51.

${ }^{1038}$ AKKr 174/614, s. 8-9.

${ }^{1039}$ AKKr 175/547, s. 55; Zak. 66; Zak. 61, s. 28: podany jako ojciec i student filozofii.

${ }^{1040}$ AKKr 175/547, s. 307; Zak. 66; Zak. 61, s. 153.

${ }^{1041}$ AKKr 174/614, s. 16-17.

1042 Zak. 61, s. 272.

${ }^{1043}$ AKKr 175/547, s. 271; Zak. 66: podana druga data zgonu 18 maja 1813; Zakonnicy, s. 337. podany tylko rok zgonu 1813 i określony jako były karmelita; Archiwum Archidiecezjalne w Gdańsku-Oliwie, Parafia Giemlice, sygn. D 160, zgony 1741-1826, s. 000: zmarł 6 maja 1813 jako wikariusz w Giemlicach w wieku 29 lat po roku pracy w tej parafii.

${ }^{1044}$ AKKr 174/614, s. 38: podana data zgonu 13 grudnia 1772; Kart. 27, s. 409; AKKr 175/547, s. 711; Zak. 66; Zak. 61, s. 338 .

${ }^{1045}$ AKKr 174/614, s. 32: podana data zgonu 9 maja 1749; Kart. 27, s. 415; AKKr 175/547, s. 619; Zak. 66; Zak. 61, s. 299 i 129: podana data zgonu 9 maja 1749.

${ }^{1046}$ AKKr 174/614, s. 24-25; AKKr 175/547, s. 531; Zak. 66; Zak. 61, s. 255. 
Theodorus à S. Josepho ARP, Wolinski Josephus ${ }^{1047}$, ex prior Kcynensis et Klodaviensis, bis primitians, ex definitor provinciae, actualis subprior loci, nat. 10.09.1717, prof. 18.10.1733 Posnaniae, presb. 19.03.1740 Varsaviae, obit. 01.07.1790 Oboriis.

Theodorus à S. Stanislao RP ${ }^{1048}$, nat. 1662, prof. 1681, obit. 05.05.1694 Oboriis.

Theodorus Gałczyński ARP ${ }^{1049}$, magister novitiorum, definitor ac concionator, nat. 1811, prof. 1829, presb. 1836, obit. 16.01.1884 Oboriis.

Theodosius à S. Josepho ARP, Schnigenberg Josephus ${ }^{1050}$, STL, jubilatus, concionator Germanorum, ex prior Markovicensis, nat. 12.03.1761, prof. 23.12.1779 Gedani, presb. 11.04.1784 Varsaviae, obit. 22.07.1807 Gedani.

Theophilus à S. Dorothea $\mathrm{RP}^{1051}$, concionator Germanorum, musicus, nat. 1721, prof. 1745, presb. 1750, obit. 24.09.1773 Markovicae.

Theophilus à S. Joanne Dańkowski $\mathrm{Fr}^{1052}$, viduus et tertiarius, nat. 1785, obit. 08.02.1841 Varsaviae.

Theophilus à S. Martino ARP, Kadech Martinus ${ }^{1053}$, seniculus, ex prior Bidgostiensis, Markovicensis et Kcynensis, nat. 09.11.1677, prof. 26.04.1696, obit. 31.12.1752 Trutoviae.

Theophilus à S. Simone ARP, Wilk (Wolff) Simon ${ }^{1054}$, STL, ex provincialis 9. annis, ex prior Posnaniensis et Oboriensis, ex commisarius delegatus, praeses Capituli, vir exemplaris plenus virtutibus, vir prudens, in actibus sui regiminis maxime laudabilis; consummatus theologus adhuc in saculo, nat. 28.10.1750, prof. 23.12.1775 Gedani, presb. 15.08.1777 Varsaviae, obit. 18.07.1816 Oboriis.

Theophilus à Venerabili Sacramento $\mathrm{RP}^{1055}$, sacrista, nat. 1627, obit.19.01.1695 Posnaniae.

Thomas à Nativitate Domini RP, Nuszkowski Casimirus ${ }^{1056}$, nat. 28.02.1711, prof. 25.12.1735, obit. 15.10.1750 Lipiae.

${ }^{1047}$ AKKr 174/614, s. 2-3; Kart. 27, s. 412; AKKr 175/547, s. 367; Zak. 66; Zak. 61, s. 182; Kroniczka, s. 27 i 190: prezydent rezydencji przy kościele Najświętszej Krwi Pana Jezusa w Poznaniu w latach 1762-1763.

${ }^{1048}$ AKKr 175/547, s. 251 i 331; Zak. 66: w obu rękopisach drugi zapis zgonu z datą 15 czerwca 1694; Zak. 61, s. 125 i 165: podana druga data zgonu 14 czerwca 1694.

${ }^{1049}$ AKKr 175/547, s. 31.

${ }^{1050}$ AKKr 174/614, s. 16-17; AKKr 175/547, s. 409; Zak. 66: podane miejsce zgonu i pochówku Pelplin; Zak. 61, s. 203: podane miejsce zgonu i pochówku Pelplin; Biblioteka Wyższego Seminarium Duchownego w Pelplinie, Ms. 310 (631), s. 222: zmarł i został pochowany kościele klasztornym cystersów w Pelplinie; Braniewo, s. 205 (wpis nr 5524); Kloskowski, Sylwetki, s. 264; syn Ignacego i Barbary. Urodził się w Ornecie na Warmii. Od 31 sierpnia 1774 kształcił się w gimnazjum jezuickim w Braniewie. Brat cystersa pelplińskiego Kwiryna (1766-1802).

${ }^{1051}$ AKKr 174/614, s. 38; AKKr 175/547, s. 539; Zak. 66; Zak. 61, s. 259.

1052 Zak. 66.

${ }^{1053}$ AKKr 174/614, s. 33; Kart. 27, s. 407; AKKr 175/547, s. 735; Zak. 66.

${ }^{1054}$ AKKr 174/614, s. 14-15; AKKr 175/547, s. 401; Zak. 66; ADP, C 54a, s. 126: członek konwentu w Gdańsku w 1776. Tonsurę i niższe święcenia otrzymał 1 maja 1776 w kościele św. Wojciecha pod Gdańskiem, subdiakonatu 1 czerwca 1776 w kościele karmelitów w Gdańsku i diakonatu 24 sierpnia 1776 w kościele św. Wojciecha pod Gdańskiem z rąk sufragana chełmińskiego Franciszka Fabiana Pląskowskiego.

${ }^{1055}$ AKKr 175/547, s. 37; Zak. 66; Zak. 61, s. 21: podana data zgonu 21 stycznia 1695.

${ }_{1056}$ AKKr 174/614, s. 32: podana data zgonu 7 października 1750; Kart. 27, s. 412; AKKr 175/547, s. 581; Zak. 66; Zak. 61, s. 272: podana data zgonu 7 października 1750 oraz imiona za- 


\section{Thomas à Pasione Domini $\rightarrow$ Thomas à Nativitate Domini}

Thomas à Pasione Domini $\mathrm{RP}^{1057}$, STL, jubilatus, nat. 1669, prof. 1687, obit. 01.12.1708 Gedani.

Thomas à S. Andrea Corsino ARP, Grabinski Mathias ${ }^{1058}$, concionator Polonorum, emeritus, actualis definitor provinciae et subprior loci, nat. 07.09.1732, prof. 16.10.1751 Gedani, presb. 06.01.1756 Varsaviae, obit. 22.04.1787 Klodaviae.

Thomas à S. Constantino RP, Dembek Constantinus ${ }^{1059}$, nat. 26.01.1774.

Thomas à S. Ignatio Janowicz RP ${ }^{1060}$, actualis procurator loci, per aliquot annos vicarius parochiarum Świedziebnia, Kikoł et Dulsk, ultimo reversus monasterium quasi concionator, nat. 1843, presb. 1867, obit. 24.09.1913 Oboriis.

Thomas à S. Joachimo Fr, Jelinski Joannes ${ }^{1061}$, terminarius, bene meritus, portarius, nat. 1711, prof. 01.01.1753 Posnaniae, obit. 10.04.1794 Gedani.

Thomas à S. Maria Magdalena de Pazzis RP ${ }^{1062}$, nat. 1691, prof. 1707, obit. 17.02.1728 Posnaniae.

Thomas Petrus à S. Agnete RP ${ }^{1063}$, obit. 03.09.1754 Kcynae.

Tiburtius à S. Francisco RP, Wisniewski Franciscus ${ }^{1064}$, ex concionator, cantor, choralis egregius, nat. 19.09.1717, prof. 17.04.1736, obit. 13.12.1756 Oboriis in Capellania.

Tiburtius à S. Friderico ARP, Salomon Fridericus ${ }^{1065}$, ex prior Lipiensis et Trutoviensis, ex custos provinciae, nat. 22.07.1767, prof. 19.07.1783 Gedani, presb. 01.01.1791 Plonscii, obit. 31.12.1848 Trutoviae.

Tilmanus à S.P.N. Elia ARP ${ }^{1066}$, ex vicarius provinciae, obit. 18.01.1690 Posnaniae.

konne Thomas à Pasione Domini; ADP, A 16, s. 60: członek konwentu w Lesznie w 1738. Tonsurę i niższe święcenia otrzymał 20 września 1738 w kolegiacie w Warszawie z rąk sufragana chełmińskiego Macieja Aleksandra Sołtyka.

${ }^{1057}$ AKKr 175/547, s. 675; Zak. 66; Zak. 61, s. 327; ADP, A 41, s. 11v: członek konwentu w Gdańsku w 1694. Święcenia prezbiteratu otrzymał 5 czerwca 1694 w katedrze w Chełmży z rąk sufragana chełmińskiego Tomasza Skotnickiego.

${ }^{1058} \mathrm{AKKr}$ 174/614, s. 6-7; AKKr 175/547, s. 223: podana data zgonu 21 kwietnia 1787; Zak. 66; Zak. 61, s. 112; Kroniczka, s. 77, 92 i 194: kaznodzieja zwyczajny w klasztorze Bożego Ciała w Poznaniu w 1766 i niedzielny w 1767.

${ }^{1059}$ Brak ksiąg chrztów parafii Wejherowo z podanych lat; AKKr 174/614, s. 20. Biogramy: PSB, T.5, s. 62-63. Manteuffel M., Dembek Konstanty Tomasz (1772-1828), profesor teologii oraz SBPN, Suplement 2, s. 62-63. Szews J., Dembek Konstanty Tomasz (1772-1828), karmelita, prof. teologii, dyr. Drukarnii Rządowej; ADP, C 54a, s. 168 i 169: członek konwentu w Gdańsku w 1797. Święcenia subdiakonatu otrzymał 3 maja 1797, diakonatu 8 maja 1797 i prezbiteratu 19 maja 1797 w Chełmży z rąk sufragana chełmińskiego Iwona Onufrego Rogowskiego.

${ }^{1060}$ AKKr 175/547, s. 539.

${ }^{1061}$ AKKr 174/614, s. 22-23: brak daty urodzenia; AKKr 175/547, s. 201; Zak. 61, s. 100: podana data zgonu 10 kwietnia 1774; Zakonnicy, s. 336: podany tylko rok zgonu.

${ }^{1062}$ AKKr 175/547, s. 95; Zak. 66; Zak. 61, s. 48; Zakonnicy, s. 333: podany rok zgonu 1729 i miejsce Gdańsk.

${ }^{1063}$ AKKr 174/614, s. 33.

${ }^{1064} \mathrm{AKKr} 174 / 614$, s. 34: podana data zgonu 19 kwietnia 1756; Kart. 27, s. 412; AKKr 175/547, s. 35; Zak. 66; Zak. 61, s. 338 i 109: podana data zgonu 19 kwietnia 1756.

${ }^{1065}$ AKKr 174/614, s. 16-17; AKKr 175/547, s. 735; Zak. 66.

${ }^{1066}$ AKKr 175/547, s. 35; Zak. 66; Zak. 61, s. 18. 
Timotheus à S. Constantino ARP, Rudnicki Constantinus ${ }^{1067}$, ex prior, ex definitor provinciae, nat. 17.03.1717, prof. 28.01.1734 Posnaniae, presb. 09.09.1741 Gedani, obit. 26.01.1788 Plonscii.

Timotheus à S. Josepho ARP, Morawski Josephus ${ }^{1068}$, ex prior Trutoviensis, nat. 31.03.1769, prof. 11.03.1789 Posnaniae, obit. 27.02.1814 Plonscii.

Timotheus à S. Laurentio ARP, Gruchalski Laurentius ${ }^{1069}$, STL, ex provincialis, 10 annis magister novitiorum, actualis definitor provinciae, nat. 08.08.1692, prof. 03.10.1709, obit. 17.03.1752 Posnaniae.

Timotheus à S. Michaele Iwaczkowski RP ${ }^{1070}$, capellanus ad ecclesiam parochialem in Baboszew, nat. 1803, prof. 1820, presb. 1829, obit. 02.03.1831 Plonscii.

Tobias à S. Brunone $\rightarrow$ Tobias à $\mathrm{S}$. Crispino

Tobias à S. Crispino Fr, Pohl Ambrosius ${ }^{1071}$, terminarius, nat. 15.09.1683, prof. 03.02.1705, obit. 27.11.1745 Kcynae.

Tobias à $\mathrm{S}$. Cypriano $\rightarrow$ Tobias à $\mathrm{S}$. Crispino

Tobias à $\mathrm{S}$. Jacobo $\rightarrow$ Tobias à $\mathrm{S}$. Thoma

Tobias à S. Nicolao $\mathrm{Fr}^{1072}$, nat. 1668, prof. 1692, obit. 02.07.1703 Posnaniae.

Tobias à S. Thoma $\mathrm{Fr}^{1073}$, braxator et terminarius, nat. 1727, prof. 1747, obit. 24.03.1762 Klodaviae.

Ubaldus à S. Andrea ARP, Murzynowski Andreas ${ }^{1074}$, STL, ex prior Oboriensis et Posnaniensis, ubi ejus activitate sacristia a fundamentis cum sepulchro fratrum nostrorum aedificata est atque eximiis picturis et sculpturis adornata, ex provincialis, actualis custos provinciae, nat. 29.11.1711, prof. 31.05.1728, obit. 05.05.1758 Oboriis.

Ubaldus à S. Jacobo ARP, Byttner Jacobus ${ }^{1075}$, ex concionator Polonorum, ex definitor, ex magister novitiorum, ex prior Kcynensis, Oboriensis, Plonscensis et Bidgostiensis, actualis subprior loci, nat. 30.03.1742, prof. 19.11.1761 Posnaniae, presb. 31.03.1766 Varsaviae, obit. 28.07.1794 Kcynae.

${ }^{1067}$ AKKr 174/614, s. 2-3: podana data zgonu 27 stycznia 1788; Kart. 27, s. 412; AKKr 175/547, s. 51; Zak. 66: podane, że zmarł i pochowany w Raciążu; Zak. 61, s. 24: podana data zgonu 24 stycznia 1788; Kroniczka, s. 200: definitor prowincji w 1769, mylony w Kroniczce z Tymoteuszem od św. Wawrzyńca.

${ }^{1068}$ AKKr 174/614, s. 18-19; AKKr 175/547, s. 115; Zak. 66.

${ }^{1069}$ AKKr 174/614, s. 32; Kart. 27, s. 408; AKKr 175/547, s. 153; Zak. 66; Zak. 61, s. 76; Kroniczka, s. 163 i 200: mistrz nowicjatu w klasztorze Bożego Ciała w Poznaniu w 1731. Błędnie podane, że był definitorem w 1769 . Wtedy już nie żył.

${ }^{1070}$ AKKr 175/547, s. 125; Zak. 66.

${ }^{1071}$ AKKr 174/614, s. 31: podane imiona Tobias à S. Cypriano; Kart. 27, s. 414; AKKr 175/547, s. 667; Zak. 66; Zak. 61, s. 322: data zgonu 26 listopada 1745 oraz imiona Tobias à S. Brunone.

${ }^{1072}$ AKKr 175/547, s. 369; Zak. 66; Zak. 61, s. 183.

1073 AKKr 174/614, s. 35: podana data zgonu 29 marca 1762 oraz imiona Tobias à S. Jacobo; AKKr 175/547, s. 167; Zak. 66; Zak. 61, s. 88: podana data zgonu 29 marca 1762.

${ }^{1074}$ AKKr 174/614, s. 34: podana data zgonu 8 maja 1758; Kart. 27, s. 410; AKKr 175/547, s. 251; Zak. 66; Zak. 61, s. 125; ADP, A 16, s. 34 i 35: członek konwentu w Oborach w 1735. Święcenia prezbiteratu otrzymał 6 marca 1735 w kościele parafialnym w Lubawie z rąk sufragana chełmińskiego Macieja Aleksandra Sołtyka.

${ }^{1075}$ AKKr 174/614, s. 8-9; AKKr 175/547, s. 421; Zak. 66; Zak. 61, s. 203: podana data zgonu 22 lipca 1794; Kroniczka, s. 166 i 200: koadjutor syndyka. Przebywał w rezydencji przy kościele Najświętszej Krwi Pana Jezusa w Poznaniu od czerwca 1769. Przeor w Kcyni w 1780. 
Ubaldus à S. Vincentio Plewiński ARP ${ }^{1076}$, ex prior Oboriensis ac actualis definitor provinciae, statura pusillus, ast ingenio magnus, musicus et philosophus, nat. 1781, prof. 1809, presb. 1814, obit. 09.12.1833 Klodaviae.

Udalricus à S. Procopio RP, Gorner (Gerner) Christophorus ${ }^{1077}$, musicus, nat. 17.05.1722, prof. 10.12.1743 Gedani, presb. 04.02.1748 Posnaniae, obit. 20.08.1790 Kcynae.

Urbanus à S. Bartholomaeo Fr, Zwiąska Bartholomaeus ${ }^{1078}$, nat. 24.08.1749, prof. 28.05.1774 Gedani, obit. 14.04.1784 Drohobiciis.

Urbanus à S. Bernardo Malecki $\mathrm{Fr}^{1079}$, terminarius, nat. 1761, prof. 1785, obit. 22.01.1805 Plonscii.

Urbanus à S. Georgio ARP, Siemierowski Ignatius (Georgio) ${ }^{1080}$, STL, jubilatus, ex prior Bidgostiensis, nat. 05.05.1726, prof. 25.01.1743 Gedani, presb. 11.04.1751 Posnaniae, obit. 11.06.1799 Klodaviae.

Urbanus à S. Josepho Fr ${ }^{1081}$, nat. 1768, prof. 1796, obit. 22.02.1805 Plonscii.

Urbanus à S. Mathia $\mathrm{Fr}^{1082}$, nat. 1666, prof. 1691, obit. 05.07.1709 Posnaniae.

Urbanus à S. Spiritu RP ${ }^{1083}$, ex concionator Polonorum, subprior loci, nat. 1708, prof. 1726, obit. 15.05.1741 Markovicae.

Urbanus à $S$. Valentino $\rightarrow$ Urbanus à S. Josepho

Urbanus à S. Venceslao $\mathrm{Fr}^{1084}$, nat. 1639, prof. 1660, obit. 07.01 .1680 Gedani.

Valentinus à S. Agnete ARP, Zbijewski Joannes Rochus ${ }^{1085}$, concionator Polonorum, jubilatus, ex definitor ac ex secretarius provinciae, ex prior Markovicensis, nat. 13.03.1713, prof. 14.02.1730, obit. 11.06.1769 in villa Rokworowo, sepultus Posnaniae.

${ }^{1076}$ AKKr 175/547, s. 691; Zak. 66: podana data zgonu 15 grudnia 1833; AAG, ACon G II 3, s. 3: syn Jakuba. Członek konwentu w Kłodawie w 1812. Tonsurę i niższe święcenia otrzymał 6 września 1812 w kościele parafialnym w Kole z rąk sufragana gnieźnieńskiego Ignacego Bardzińskiego.

1077 AKKr 174/614, s. 4-5; Kart. 27, s. 414: podana data złożenia profesji zakonnej 24 grudnia 1743; AKKr 175/547, s. 467; Zak. 66; Zak. 61, s. 224.

${ }^{1078} \mathrm{AKKr} 174 / 614$, s. 26-27: wpis odnotowany dwukrotnie na tych stronach rękopisu, drugi raz $\mathrm{z}$ datą zgonu.

${ }^{1079}$ AKKr 175/547, s. 43; Zak. 66.

${ }^{1080}$ AKKr 174/614, s. 4-5; Kart. 27, s. 413; AKKr 175/547, s. 325; Zak. 66; Zak. 61, s. 162.

${ }^{1081}$ AKKr 175/547, s. 105; Zak. 61, s. 22: podana data zgonu 22 stycznia 1805 oraz imiona zakonne Urbanus à $S$. Valentino.

${ }^{1082}$ AKKr 175/547, s. 375; Zak. 66; Zak. 61, s. 186.

${ }^{1083}$ AKKr 175/547, s. 271; Zak. 66; Zak. 61, s. 135.

${ }^{1084}$ AKKr 175/547, s. 13; Zak. 66; Zak. 61, s. 7.

${ }^{1085}$ AKKr 174/614, s. 37; Kart. 27, s. 411; AKKr 175/547, s. 331: podana data zgonu 14 czerwca 1769; Zak. 66: podana data zgonu 14 czerwca 1769; Zak. 61, s. 162; ADP, A 16, s. 41 i 42: członek konwentu w Poznaniu w 1735. Tonsurę i niższe święcenia otrzymał 20 listopada 1735, święcenia subdiakonatu 25 listopada 1735 i diakonatu 27 listopada 1735 w Chełmży z rąk sufragana chełmińskiego Macieja Aleksandra Sołtyka; Kroniczka, s. 28, 34 i 190: nowicjusz w klasztorze Bożego Ciała w Poznaniu w 1730. Przebywał w rezydencji przy kościele Najświętszej Krwi Pana Jezusa w Poznaniu w 1763. 
Valentinus à S. Francisco RP, Zieminski Franciscus ${ }^{1086}$, concionator festivalis, nat. 27.09.1742, prof. 28.06.1761 Posnaniae, presb. 31.03.1766 Varsaviae, obit. 02.03.1791 Klodaviae.

Valentinus à S. Joanne Baptista Fr, Klinicki Joannes ${ }^{1087}$, organarius, choralis, sartor, nat. 1694, prof. 12.03.1716, obit. 25.11.1774 Plonscii.

Valentinus à S. Josepho Fr, Rozewski (Rojewski) Josephus ${ }^{1088}$, terminarius, nat. 20.02.1755, prof. 14.03.1782 Gedani, obit. 12.11.1814 Klodaviae.

Valerianus à S. Anna ARP, Magawka Petrus ${ }^{1089}$, ex prior Drohobicensis, nat. 24.02.1715, prof. 12.08.1736 Posnaniae, presb. 16.07.1741 Kcynae, obit. 30.05.1784 Lipiae.

Valerianus à S. Cantio RP, Dziembinski Cantius ${ }^{1090}$, nat. 17.10.1767, prof. 19.02.1787 Posnaniae.

Valerianus à S. Joanne Baptista Fr, Kliniecki Joannes ${ }^{1091}$, prof. 17.03.1712 Posnaniae, obit. 26.04.1774 Plonscii.

Valerianus Wierzbicki ARP ${ }^{1092}$, ex Ordine Dominicanorum; ex prior Rozdoliensis et Pilznensis, ex magister novitiorum, sacrista loci, nat. 1868, presb. 1890, prof. 1893, obit. 21.03.1932 Oboriis.

Valerius à S. Joanne RP, Romanowski Joannes ${ }^{1093}$, nat. 02.01.1739, prof. 08.05.1777 Gedani, presb. 08.09.1777 Plonscii, obit. 09.09.1812 Kcynae.

Venantius à S. Hyppolito Fr, Kossakowski Hyppolitus ${ }^{1094}$, clericus, studens philosophiae, nat. 02.07.1771, prof. 1690, obit. 09.07.1791 Klodaviae.

Venantius à S. Mathaeo Maliszewski RP ${ }^{1095}$, concionator et subprior loci, nat. 1775, prof. 1792, presb. 1796, obit. 14.01.1815 Plonscii.

Venantius à S. Valentino Murkiewicz RP ${ }^{1096}$, concionator, professor theologiae, nat. 1801, prof. 1819, presb. 1824, obit. 22.06.1830 Guloviae.

Venantius ab Inventione S. Crucis Fr, Wałczyński Josephus ${ }^{1097}$, aeconumus in Nova Fundatione Jasienecensi, nat. 17.05.1708, prof. 05.05.1742, obit. 15.02.1750 Jasieneci.

${ }^{1086}$ AKKr 174/614, s. 8-9: data zgonu 3 marca 1791; AKKr 175/547, s. 123; Zak. 66; Zak. 61, s. 61.

${ }^{1087}$ AKKr 174/614, s. 39: podana data zgonu 26 kwietnia 1774; Kart. 27, s. 414: brak daty urodzenia; AKKr 175/547, s. 663; Zak. 66; Zak. 61, s. 114 i 322: podane daty zgonu 24 kwietnia 1774 i 26 listopada 1774.

${ }^{1088}$ AKKr 174/614, s. 26-27; AKKr 175/547, s. 637; Zak. 66.

${ }^{1089}$ AKKr 174/614, s. 2-3; Kart. 27, s. 412; AKKr 175/547, s. 301; Zak. 66; Zak. 61, s. 150; Kroniczka, s. 69, 81 i 194: prezydent rezydencji przy kościele Najświętszej Krwi Pana Jezusa w Poznaniu w 1766. Po rezygnacji w październiku 1766 udał się do klasztoru w Markowicach.

${ }^{1090}$ AKKr 174/614, s. 18-19.

${ }^{1091}$ AKKr 174/614, s. 22-23: w rękopisie brak daty urodzenia.

${ }^{1092}$ AKKr 175/547, s. 161.

${ }^{1093}$ AKKr 174/614, s. 14-15; AKKr 175/547, s. 509; ADWł, ABSWł 10, s. 64: członek konwentu w Płońsku w 1777. Święcenia diakonatu otrzymał 17 sierpnia 1777 i prezbiteratu 24 sierpnia 1777 we Włocławku z rąk sufragana włocławskiego Jana Dembowskiego.

${ }^{1094}$ AKKr 174/614, s. 20; AKKr 175/547, s. 383; Zak. 66; Zak. 61, s. 190.

${ }^{1095}$ AKKr 175/547, s. 27; Zak. 66.

${ }^{1096}$ AKKr 175/547, s. 347 i 349: podana druga data zgonu 21 czerwca 1830.

${ }^{1097}$ AKKr 174/614, s. 32; Kart. 27, s. 415; AKKr 175/547, s. 75; Zak. 66; Zak. 61, s. 38: podana data zgonu 7 lutego 1750. 
Venceslaus à S. Casimiro $\mathrm{Fr}^{1098}$, terminarius, nat. 1664, prof. 1708, obit. 08.03.1724 Gedani.

Venceslaus à $\mathrm{S}$. Crispiniano $\rightarrow$ Venceslaus à $\mathrm{S}$. Crispino

Venceslaus à S. Crispino Fr, Fischer Petrus ${ }^{1099}$, murarius, nat. 1713, prof. 08.10.1743, obit. 18.04.1758 Klodaviae.

Venceslaus à S. Georgio RP, Werski Georgius ${ }^{1100}$, ex concionator Germanorum, nat. 24.04.1698, prof. 26.09.1717, obit. 09.09.1750 Posnaniae.

Venceslaus à S. Mathaeo ARP, Piechowicz Mateusz ${ }^{1101}$, vario tempore annis 37 prior Klodaviensis, interpolatis triennis definitor provinciae, ex prior Bidgostiensis, praeses Capituli, secretarius provinciae, qui Conventum Klodaviensem et caetera aedificia sua cura aedificavit; ecclesiam altaribus, confessionalibus, ac picturis eleganter adornavit, bis primitians, nat. 22.09.1734, prof. 16.11.1751 Posnaniae, presb. 15.10.1756 Varsaviae, obit. 25.12.1812 Klodaviae.

Venceslaus à S. Stanislao $\mathrm{Fr}^{1102}$, tegularius, nat. 1722, prof. 1756, obit. 31.08 .1770 Klodaviae.

Venceslaus à Transfiguratione Domini ARP ${ }^{1103}$, STL, ex prior loci, nat. 1666, prof. 1684, obit. 08.12.1709 Bidgostiae.

Victor à S. Antonio RP, Nowinski Antonius ${ }^{1104}$, ex secretarius provinciae, ex prior Lipiensis, nat. 14.10.1738, prof. 19.02.1755 Posnaniae, presb. 25.12.1761 Varsaviae, obit. 18.08.1796 Oboriis.

Victor à S. Josepho Fr, Ostaszewski Sebastianus ${ }^{1105}$, religiosus morigeratus, terminarius, aeconomus laudabilis, bene commendatus et exemplaris, nat. 19.02.1710, prof. 24.12.1742 Gedani, obit. 31.08.1778 Posnaniae in Residentia.

Victor à S. Vincentio $\mathrm{Fr}^{1106}$, subdiaconus, nat. 1711, prof. 1731, obit. 16.03.1736 Kcynae.

Victorianus Połczyński $\mathrm{Fr}^{1107}$, sartor et terminarius, nat. 1766, prof. 1788, obit. 09.03.1831 Trutoviae.

${ }^{1098}$ AKKr 175/547, s. 135; Zak. 66; Zak. 61, s. 65: podana data zgonu 6 marca 1724; Zakonnicy, s. 333: podany tylko rok zgonu.

${ }^{1099} \mathrm{AKKr} 174 / 614$, s. 34; Kart. 27, s. 416: brak daty urodzenia; AKKr 175/547, s. 217: podane imiona zakonne Venceslaus à S. Crispiniano; Zak. 66: podane imiona zakonne Venceslaus à S. Crispiniano; Zak. 61, s. 108.

${ }^{1100}$ AKKr 174/614, s. 32; Kart. 27, s. 409; AKKr 175/547, s. 509; Zak. 66; Zak. 61, s. 242: podana data zgonu 7 września 1750.

${ }^{1101}$ AKKr 174/614, s. 6-7; Zak. 66.

${ }^{1102}$ AKKr 174/614, s. 37: podana data zgonu 30 sierpnia 1770; AKKr 175/547, s. 491; Zak. 66; Zak. 61, s. 234: podana data zgonu 30 sierpnia 1770.

${ }^{1103}$ AKKr 175/547, s. 689; Zak. 66; Zak. 61, 335: podana data zgonu 10 grudnia 1709. Rok poprawiony na 1739 .

${ }^{1104}$ AKKr 174/614, s. 6-7; AKKr 175/547, s. 465: podana data zgonu 19 sierpnia 1796; Zak. 66; ADP, C 54a, s. 29: członek konwentu w Gdańsku w 1758. Tonsurę i niższe święcenia otrzymał 11 czerwca 1758 w Kartuzach z rąk sufragana chełmińskiego Franciszka Fabiana Pląskowskiego.

${ }^{1105}$ AKKr 174/614, s. 22-23 i 40: na s. 22-23 podane miejsce zgonu Kcynia; Kart. 27, s. 416; AKKr 175/547, s. 453 i 491: drugi zapis odnotowany 13 sierpnia 1778; Zak. 66; Zak. 61, s. 235.

${ }^{1106}$ AKKr 175/547, s. 151; Zak. 66; Zak. 61, s. 75; ADP, A 16, s. 33 i 33: członek konwentu w Kcyni w 1735. Tonsurę i niższe święcenia otrzymał 15 stycznia 1735, święcenia subdiakonatu 17 stycznia 1735 w Chełmży z rąk sufragana chełmińskiego Macieja Aleksandra Sołtyka.

${ }^{1107}$ AKKr 175/547, s. 137; Zak. 66: podana data zgonu 14 września 1829. 
Vincentius à S. Adalberto Zdrojewski RP ${ }^{1108}$, nat. 1798, prof. 1826, presb. 1827, obit. 01.01.1858 Varsaviae.

Vincentius à S. Anastasio ARP ${ }^{1109}$, ex prior loci, nat. 1684, prof. 1702, obit. 24.07.1724 Kcynae.

Vincentius à S. Antonio ARP, Turowski Antonius ${ }^{1110}$, STL, jubilatus, ex prior Plonscensis et Oboriensis, nat. 23.11.1717, prof. 17.04.1736, obit. 18.11.1759 Varsaviae.

Vincentius à S. Jacobo RP, Laus Jacobus ${ }^{1111}$, ex lector philosophiae, ex subprior, nat. 19.03.1741, prof. 15.06.1761 Gedani, presb. 06.10.1765 Posnaniae, obit. 26.06.1801 Trutoviae.

Vincentius à S. Stanislao RP ${ }^{111}$, concionator Polonorum, nat. 1701, prof. 1719, obit. 03.04.1729 Gedani.

Vincentius Kruszewski RP ${ }^{1113}$, vir exemplaris, in oratione et celebratione assiduus, a populo valde veneratus et amatus, sacrista, obiit in odore sanctitatis, nat. 1843, obit. 06.10.1922 Oboriis.

Vitalis à S. Adalberto RP, Dybinski Adalbertus ${ }^{114}$, nat. 31.03.1740, prof. 02.04.1756 Posnaniae, presb. 28.09.1763 Posnaniae, obit. 31.03.1799 Bidgostiae.

Vitalis à S. Joanne Fr, Cuperski Joannes ${ }^{1115}$, nat. 20.06.1753, prof. 12.07.1777 Gedani, obit. 01.01.1791 Kcynae.

Vitalis à S. Prothasio RP ${ }^{1116}$, nat. 1659, prof. 1677, obit. 19.06.1709 Posnaniae.

Vitalis à S. Valentino RP, Remberkowicz Valentinus ${ }^{117}$, nat. 04.02.1713, prof. 14.02.1731, obit. 07.12.1746 Posnaniae.

Vladislaus à S. Antonio Bieńkowski (Bińkowski) RP ${ }^{1118}$, ex concionator Varsaviensis et Klodaviensis, ex subprior Trutoviensis et Guloviensis, nat. 1792, prof. 1816, presb. 1823, obit. 26.10.1837 Trutoviae.

1108 Zak. 66.

${ }^{1109}$ AKKr 175/547, s. 413; Zak. 66; Zak. 61, s. 205.

${ }^{1110}$ AKKr 174/614, s. 34: podana data zgonu 27 września 1759; Kart. 27, s. 412; AKKr 175/547, s. 649; Zak. 66; Zak. 61, s. 323: podana data zgonu 27 listopada 1759.

${ }^{1111}$ AKKr 174/614, s. 8-9; Zak. 66; Zak. 61, s. 167: podana data zgonu 16 czerwca 1801; ADP, C 54a, s. 63: członek konwentu w Poznaniu w 1765. Święcenia prezbiteratu otrzymał 21 września 1765 w Chełmży z rąk sufragana chełmińskiego Franciszka Fabiana Pląskowskiego.

1112 AKKr 175/547, s. 187; Zak. 66; Zak. 61, s. 93; Zakonnicy, s. 333: podana data zgonu 5 kwietnia 1729.

1113 AKKr 175/547, s. 563.

${ }^{1114}$ AKKr 174/614, s. 6-7; Zak. 66; Zak. 61, s. 90; Mańkowski, Liber mortuorum, s. 123: konfrater cystersów koronowskich.

${ }^{1115}$ AKKr 174/614, s. 26-27; AKKr 175/547, s. 1; Zak. 61, s. 1.

${ }^{1116}$ AKKr 175/547, s. 343; Zak. 66; Zak. 61, s. 171: podana data zgonu 20 czerwca 1709.

${ }^{1117}$ AKKr 174/614, s. 31: podany data zgonu 19 marca 1746 w miejscowości Iłowiec w dekanacie kościańskim diecezji poznańskiej; Kart. 27, s. 411; AKKr 175/547, s. 687; Zak. 66; Zak. 61, s. 77: podana data zgonu 18 marca 1746; ADP, A 16, s. 41 i 42: członek konwentu w Poznaniu w 1735. Tonsurę i niższe święcenia otrzymał 20 listopada 1735, święcenia subdiakonatu 25 listopada 1735 i diakonatu 27 listopada 1735 w Chełmży z rąk sufragana chełmińskiego Macieja Aleksandra Sołtyka.

${ }^{1118}$ AKKr 175/547, s. 603; Zak. 66. 
Vladislaus à S. Antonio RP, Wolski Antonius ${ }^{1119}$, STL triennalis, obiit pridie recurrentis memoriae obitus dignissimi eiusdem patrui, de quo cras, nat. 13.06.1755, prof. 22.11.1774 Gedani, presb. 08.09.1778 Varsaviae, obit. 21.06.1787 Posnaniae.

Vladislaus à $S$. Joanne $\rightarrow$ Vladislaus à $S$. Ludovico

Vladislaus à S. Joanne Fr, Knoch Georgius ${ }^{1120}$, nat. 03.03.1713, prof. 15.07.1732, obit. 13.09.1766 Gedani.

Vladislaus à S. Josepho Fr, Tomaszewski Josephus ${ }^{1121}$, musicus, organarius et choralis, nat. 1746, prof. 30.01.1768 Gedani, obit. 17.01.1795 Bidgostiae.

Vladislaus à S. Ludovico RP, Hahn Joannes ${ }^{1122}$, ex lector philosophiae ac theologiae moralis, nec non subprior, nat. 08.06.1714, prof. 10.09.1732, obit. 26.03.1773 Plonscii.

Vladislaus à S. Paulino RP ${ }^{1123}$, nat. 1645, prof. 1664, obit. 17.11.1688 Posnaniae.

Xaverius à S. Alberto (Adalberto) RP, Piotrowicz Xaverius ${ }^{1124}$, procurator, nat. 22.04.1717, prof. 15.10.1734, obit. 24.04.1758 Klodaviae.

Xaverius à S. Antonio RP, Grąmbczewski Antonius ${ }^{1125}$, studens theologiae, nat. 21.12.1766, prof. 31.12.1788 Gedani, presb. 1794 Varsaviae, obit. 31.03.1794 Varsaviae.

Xaverius à S. Paulo RP, Broikiewicz Paulus ${ }^{126}$, concionator Polonorum, nat. 11.02.1747, prof. 27.09.1768 Gedani, presb. 1773 Kcynae, obit. 25.03.1787 Lipiae.

Zacharias à Passione Domini RP ${ }^{1127}$, concionator Polonorum et Germanorum, nat. 1682, prof. 1706, obit. 24.05.1736 Oboriis.

Zacharias à S. Carolo $\mathrm{Fr}^{1128}$, organarius, nat. 1737, prof. 1760, obit. 07.10.1790 Varsaviae.

${ }^{1119}$ AKKr 174/614, s. 14-15; AKKr 175/547, s. 347; Zak. 66; H. Łaszewski, Walenty Wolski z Niestępowa i jego potomkowie, [w:] „Zapiski Towarzystwa Naukowego w Toruniu”, 1: 1908, z. nr 2, s. 33-34: syn Aleksandra Wolskiego i Jadwigi Lewińskiej. Brat Jakub był kanonikiem chełmińskim, Walenty dziedzicem w Niestępowie i Aleksander dziedzicem w Będargowie. Miał jeszcze brata Szczepana i siostry: Walerię Józefę, Joannę, Tekle i Annę; ADP, C 54a, s. 124: członek konwentu w Gdańsku w 1775. Tonsurę i niższe święcenia otrzymał 25 maja 1775 w kościele św. Wojciecha pod Gdańskiem z rąk sufragana chełmińskiego Franciszka Fabiana Pląskowskiego.

${ }^{1120}$ AKKr 174/614, s. 36; Kart. 27, s. 415; AKKr 175/547, s. 517; Zak. 66; Zak. 61, s. 248; Zakonnicy, s. 335.

${ }^{1121}$ AKKr 174/614, s. 24-25: błędnie podana data zgonu 1 stycznia 1794; AKKr 175/547, s. 33; Zak. 66; Zak. 61, s. 273: podana data zgonu 8 października 1795; Mańkowski, Liber mortuorum, s. 112: konfrater cystersów koronowskich.

${ }_{1122}$ AKKr 174/614, s. 38: podana data zgonu 27 marca 1773; Kart. 27. s. 411; AKKr 175/547, s. 171; Zak. 66; Zak. 61, s. 85: podane imiona zakonne Vladislaus à S. Joanne.

${ }^{1123}$ AKKr 175/547, s. 647; Zak. 66; Zak. 61, s. 313.

${ }^{1124}$ AKKr 174/614, s. 34; Kart. 27, s. 412; AKKr 175/547, s. 229; Zak. 66; Zak. 61, s. 114; AAG, ACon G II 4, s. 18v (s i d) i 20: członek konwentu w Kłodawie w 1740. Święcenia subdiakonatu otrzymał 11 listopada 1740, diakonatu 13 listopada 1740 i prezbiteratu 1 grudnia $1740 \mathrm{w}$ kaplicy domu misjonarzy w Łowiczu z rąk sufragana gnieźnieńskiego Krzysztofa Dobińskiego.

${ }^{1125}$ AKKr 174/614, s. 18-19: podana data zgonu 23 marca 1794; AKKr 175/547, s. 181: podany rok święceń kapłańskich 1792; Zak. 61, s. 90.

${ }^{1126}$ AKKr 174/614, s. 10-11; AKKr 175/547, s. 169; Zak. 66; Zak. 61, s. 84.

${ }^{1127}$ AKKr 175/547, s. 289; Zak. 66; Zak. 61, s. 144; Zakonnicy, s. 334: podany tylko rok zgonu; ADP, A 41, s. 27: członek konwentu w Gdańsku w 1707. Tonsurę i niższe święcenia otrzymał 24 września 1707 w katedrze w Chełmży z rąk sufragana chełmińskiego Seweryna Szczuki.

${ }^{1128} \mathrm{AKKr}$ 175/547, s. 607: podana data zgonu 28 października 1790; Zak. 66. 
Zacharias à S. Casimiro Skrzyński RP ${ }^{1129}$, concionator, nat. 1826, prof. 1844, presb. 1851, obit. 12.03.1859 Plonscii.

Zacharias à S. Christophoro Ponka $\mathrm{ARP}^{1130}$, ex prior Trutoviensis, Klodaviensis et Lipiensis, actualis subprior loci, vir virtutibus plenus, nat. 1775, prof. 1797, presb. 1803, obit. 20.08.1837 Varsaviae.

Zacharias à S. Paulo $\mathrm{Fr}^{1131}$, nat. 1626, prof. 1651, obit. 19.06.1675 Posnaniae.

Zacharias à S.P.N. Elia Fr $^{1132}$, nat. 1652, prof. 1672, obit. 12.08.1709 Gedani.

Zacharias à Venerabili Sacramento RP, May Joannes ${ }^{1133}$, concionator Germanorum, magister novitiorum, nat. 29.09.1717, prof. 12.06.1739 Gedani, presb. 30.06.1743 Posnaniae, obit. 01.04.1789 Gedani.

Zephyrinus à S. Antonio RP, Berendt Antonius ${ }^{1134}$, ex subprior, migrans cum obedientialibus, ex concionator Trutoviensis et Lipiensis, sacrista, nat. 29.04.1711, prof. 26.09.1728 Gedani, presb. 02.07.1735 Kcynae, obit. 18.06.1777 Plonscii.

\title{
Indeks nazwisk ${ }^{1135}$
}

\author{
Alscher Antonius $\rightarrow$ Mathaeus à S. Antonio \\ Ancuta Michael $\rightarrow$ Constantinus à Jesu Maria \\ Andrykowicz Josephus $\rightarrow$ Athanasius à S. Paulo \\ Andrzejewski Jacobus $\rightarrow$ Felicianus à S. Jacobo \\ Archendt Christophorus $\rightarrow$ Laurentius à S. Christophoro \\ Arent Andreas $\rightarrow$ Florentius à S. Teresia \\ Assmann (Hassmann) Michael $\rightarrow$ Hyppolitus à S. Michaele \\ Augustynowicz Jacobus $\rightarrow$ Serenus à S. Jacobo \\ Austen Andreas $\rightarrow$ Marcellinus à S. Andrea \\ Bajer Ambrosius $\rightarrow$ Christophorus à S. Ambrosio \\ Bakier Michael $\rightarrow$ Patritius à S. Michaele \\ Balicki Jacobus $\rightarrow$ Elias à S. Jacobo \\ Balman Martinus $\rightarrow$ Athanasius à S. Martino \\ Bauch Casimirus $\rightarrow$ Gualbertus à S. Casimiro \\ Berendt Adalbertus $\rightarrow$ Mathias à S. Leone \\ Berendt Antonius $\rightarrow$ Angelus à S. Bernardo \\ Berendt Antonius $\rightarrow$ Zephyrinus à S. Antonio
}

${ }^{1129}$ AKKr 175/547, s. 143; Zak. 66.

${ }^{1130}$ AKKr 175/547, s. 467.

${ }^{1131}$ AKKr 175/547, s. 343; Zak. 66; Zak. 61, s. 168: podana data zgonu 17 czerwca 1675.

${ }^{1132}$ AKKr 175/547, s. 451; Zak. 66.

${ }^{1133}$ AKKr 174/614, s. 2-3; Kart. 27, s. 412; AKKr 175/547, s. 183; Zak. 66; Zak. 61, s. 91; Zakonnicy, s. 336: podany miesiąc kwiecień i rok.

${ }^{1134}$ AKKr 174/614, s. 2-3 i 40; Kart. 27, s. 410: podana data urodzenia 26 lutego 1728. Prawdopodobnie pomyłka z zapisem sąsiednim; AKKr 175/547, s. 341; Zak. 66; Zak. 61, s. 143 i 167: podana data zgonu 23 maja 1777 Lipia i 16 czerwca 1777; ADP, A 16, s. 32, 33 i 37: członek konwentu w Kcyni w 1735. Tonsurę i niższe święcenia otrzymał 15 stycznia 1735, święcenia subdiakonatu 17 stycznia 1735, diakonatu 21 stycznia 1735 i prezbiteratu 4 czerwca 1735 w Chełmży. Szafarzem wszystkich święceń był sufragan chełmiński Maciej Aleksander Sołtyk.

${ }^{1135} \mathrm{~W}$ indeksie zostali wymienieni tylko zakonnicy, przy których w treści zostało podane nazwisko. 
Berkowski Innocentius à $\mathrm{S}$. Adalberto $\rightarrow$ Innocentius à S. Adalberto

Berowski Jacobus $\rightarrow$ Apollinaris à S. Jacobo

Betkier Christianus $\rightarrow$ Innocentius à S. Christiano

Bęczkowski Aloysius à S. Antonio $\rightarrow$ Aloysius à S. Antonio

Białk Antonius $\rightarrow$ Alexander à S. Antonio

Białk Josephus $\rightarrow$ Bernardus à S. Josepho

Bienkowski Thomas $\rightarrow$ Paschalis à $\mathrm{S}$. Thoma

Bieńkowski Vladislaus à S. Antonio $\rightarrow$ Vladislaus à S. Antonio Bieńkowski

Biernacki Cyriacus $\rightarrow$ Cyriacus Biernacki

Biess Jacobus $\rightarrow$ Martialis à S. Jacobo

Bigoszewski Antonius $\rightarrow$ Ivo à S. Antonio

Bińkowski Vladislaus à S. Antonio $\rightarrow$ Bieńkowski Vladislaus à S. Antonio

Blöhr Josephus $\rightarrow$ Leopoldus à S. Josepho

Bładoszewski Adalbertus $\rightarrow$ Bartholomaeus à S. Adalberto

Boczenski Paulus $\rightarrow$ Raphael à S. Hieronymus

Bogulski Antonius $\rightarrow$ Arnoldus à S. Antonio

Böhm Franciscus $\rightarrow$ Daniel à S. Francisco

Bork Franciscus $\rightarrow$ Rochus à S. Francisco

Borowiecki Avertanus à S. Stanislao Kostka $\rightarrow$ Avertanus à S. Stanislao Kostka

Borowski Stanislaus $\rightarrow$ Josephus à S.P.N. Elia

Borowski Valentinus $\rightarrow$ Sigismundus à S. Valentino

Boruski Andreas $\rightarrow$ Clemens à S. Andrea

Boruski Josephus $\rightarrow$ Clemens à S. Josepho

Braus Mathias $\rightarrow$ Alexius à Visitatione B.M.V.

Bretschneider Michael $\rightarrow$ Anastius (Anastasius) à S. Brocardo

Brochocki Adalbertus $\rightarrow$ Narcissus à S. Adalberto

Brochocki Adamus $\rightarrow$ Joannes à S. Adamo

Brocki Fabianus $\rightarrow$ Georgius à S. Fabiano

Broikiewicz Paulus $\rightarrow$ Xaverius à S. Paulo

Brokhoff Antonius $\rightarrow$ Stephanus à S. Thoma

Bronisz Franciscus $\rightarrow$ Benedictus à S. Francisco

Broszkowski Joannes $\rightarrow$ Carolus à S. Bartholomaeo

Brzanski Martinus $\rightarrow$ Martinus Brzanski

Brzeczkowski Michael $\rightarrow$ Sebastianus à S. Maria

Budyq Joannes $\rightarrow$ Andreas à S. Joanne

Bukiewicz Valentinus $\rightarrow$ Nicolaus à S. Ambrosio

Burdanowicz Athanasius $\rightarrow$ Antonius à S. Athanasio

Bury Mathias $\rightarrow$ Mathias Bury

Buszewski Joannes $\rightarrow$ Simon à S. Joanne

Bylang Antonius $\rightarrow$ Crispinus à S. Antonio

Byttner Jacobus $\rightarrow$ Ubaldus à S. Jacobo

Celmer Laurentius $\rightarrow$ Laurentius ab Inventione S. Stephano

Cerbs Joannes $\rightarrow$ Leopoldus à S. Quirinus

Ceynoff Joannes $\rightarrow$ Alphonsus à S. Joanne

Charazniewicz Andreas $\rightarrow$ Alphonsus à S. Gregorio

Charazniewicz Petrus Caelestinus $\rightarrow$ Ludovicus à S. Hyacintho

Chądzynski Josephus $\rightarrow$ Justinus à S. Josepho

Chlebowski Martinus $\rightarrow$ Gregorius à S. Angelo

Chlebowski Paulus $\rightarrow$ Joannes à S. Paulo 
Chojnacki Michael à S. Joanne $\rightarrow$ Michael à S. Joanne Chojnacki

Chrostowski Andreas $\rightarrow$ Cajetanus à S. Andrea

Chwastowski Franciscus $\rightarrow$ Joannes à S. Edvardo

Chybinski Benedictus $\rightarrow$ Angelus à S. Benedicto

Cicherski Joannes $\rightarrow$ Thelesphorus à S. Josepho

Ciekalski Adalbertus $\rightarrow$ Anastasius à S. Adalberto

Cielecki Michael $\rightarrow$ Benedictus à S. Josepho

Cierpisz Ludovicus à S. Josepho $\rightarrow$ Ludovicus à S. Josepho Cierpisz

Ciupak Basilius à S. Stanislao $\rightarrow$ Basilius à S. Stanislao Ciupak

Cizowski Simon $\rightarrow$ Cyriacus à S. Simone

Cuperski Joannes $\rightarrow$ Vitalis à S. Joanne

Cwiklinski Martinus $\rightarrow$ Ceslaus à S.P.N. Elia

Cychon Jacobus $\rightarrow$ Damianus à S. Jacobo

Cylkowski Franciscus $\rightarrow$ Ambrosius à S. Francisco

Cynal Michael $\rightarrow$ Carolus à S. Michaele

Czapkowski Lucas $\rightarrow$ Lucas Czapkowski

Czaplicki Mathias $\rightarrow$ Henricus à S. Michaele

Czapski Stanislaus $\rightarrow$ Chrysostomus à S. Laurentio

Czarnecki Joannes $\rightarrow$ Augustinus à S. Tiburtio

Czayczynski Josephus $\rightarrow$ Aurelius à S. Josepho

Czaykowski Martinus $\rightarrow$ Paulus à S. Martino

Czechowicz Joannes $\rightarrow$ Josephus à S. Maria

Daberski Andreas $\rightarrow$ Damborski Andreas

Damborski Andreas $\rightarrow$ Liborius à S. Andrea

Dańkowski Theophilus à S. Joanne $\rightarrow$ Theophilus à S. Joanne Dańkowski

Darewski Jacobus $\rightarrow$ Columbanus à S. Anna

Dąbrowski Cyprianus à S. Vincentio $\rightarrow$ Cyprianus à S. Vincentio Dąbrowski

Dąbrowski Jacobus $\rightarrow$ Serapion à S. Jacobo

Dembek Constantinus $\rightarrow$ Thomas à S. Constantino

Deryng Franciscus $\rightarrow$ Chrisologus à S. Francisco

Deryng Joannes $\rightarrow$ Columbanus à S. Joanne

Deygowski Laurentius $\rightarrow$ Laurentius ab Assumptione B.M.V.

Ditloff Joannes $\rightarrow$ Mathias à S. Joanne

Dluzniewski Thomas $\rightarrow$ Lucas à S. Thoma

Dobrowolski Rochus $\rightarrow$ Clemens à S. Rocho

Dobrzynski Nicolaus $\rightarrow$ Dionysius à S. Nicolao

Domanski Josephus $\rightarrow$ Narcissus à S. Josepho

Draminski Stephanus $\rightarrow$ Felicianus à S. Stephano

Drążkowski Narcissus à S. Joanne $\rightarrow$ Narcissus à S. Joanne Drążkowski

Dryan Joannes $\rightarrow$ Adrianus à S. Joanne Baptista C.J.

Drzewicki Michael $\rightarrow$ Bartholomaeus à S. Adriano

Drzewiecki Adalbertus $\rightarrow$ Candidus à S. Adalberto

Drzniowski Fortunatus $\rightarrow$ Fortunatus Drzniowski

Durowicz Laurentius $\rightarrow$ Innocentius à Visitatione B.M.V.

Duszynski Mansvetus à S. Joanne $\rightarrow$ Mansvetus à S. Joanne Duszynski

Dybinski Adalbertus $\rightarrow$ Vitalis à S. Adalberto

Dybysławski Adamus $\rightarrow$ Alanus à S. Adamo

Dziembinski Cantius $\rightarrow$ Valerianus à S. Cantio

Dzięcielski Joannes $\rightarrow$ Sebastianus à S. Joanne 
Elwart Joannes $\rightarrow$ Antonius à S. Joanne

Fabijanowski Benedictus $\rightarrow$ Benedictus Fabijanowski

Fankydeyski Dominicus $\rightarrow$ Gervasius à S. Dominico

Felhner Josephus $\rightarrow$ Thaddaeus à S. Josepho

Fetter Josephus $\rightarrow$ Faustus à S. Josepho

Ficzkiewicz Joannes à S. Cruce $\rightarrow$ Joannes à S. Cruce Ficzkiewicz

Filipski Stanislaus $\rightarrow$ Paulus à S. Stanislao

Fischer Augustinus $\rightarrow$ Rudolphus à S. Augustino

Fischer Joannes $\rightarrow$ Mathaeus à S. Joanne

Fischer Petrus $\rightarrow$ Bonifacius à S. Venantio

Fischer Petrus $\rightarrow$ Venceslaus à S. Crispino

Francoise Franciscus $\rightarrow$ Eliseus à S. Joanne Baptista

Francose Benedictus $\rightarrow$ Alexander à $\mathrm{S}$. Benedicto

Frankiewicz Franciscus $\rightarrow$ Stanislaus à $S$. Dorothea

Freymark Carolus à S. Francisco $\rightarrow$ Carolus à S. Francisco Freymark

Friess Michael $\rightarrow$ Andreas à S. Michaele

Fromski Romualdus $\rightarrow$ Romualdus Fromski

Froncki Michael $\rightarrow$ Eadmundus à S. Michaele

Frost Brocardus à S. Georgio $\rightarrow$ Brocardus à S. Georgio Frost

Furga Michael $\rightarrow$ Hieronymus à S. Michaele

Gabrielowicz Florianus $\rightarrow$ Leo à S. Teresia

Gagalski Adamus $\rightarrow$ Salesius à S. Adamo

Gajewski Antonius $\rightarrow$ Antonius à S. Bonaventura

Gałczyński Theodorus $\rightarrow$ Theodorus Gałczyński

Gałęski Simon $\rightarrow$ Cantius à S. Juliano

Gapinski Stanislaus $\rightarrow$ Damascenus à S. Stanislao

Garulewski Joannes $\rightarrow$ Stanislaus à S. Michaele

Gerhman Antonius $\rightarrow$ Ignatius à S. Antonio

Gerigk Josephus $\rightarrow$ Daniel à S. Josepho

German Franciscus $\rightarrow$ Joachimus à S. Francisco

Gerner Christophorus $\rightarrow$ Gorner Christophorus

Gerszewski Jacobus $\rightarrow$ Eadmundus à S. Jacobo

Gertler Georgius $\rightarrow$ Balthassar à S. Georgio

Giercuszkiewicz Alphonsus $\rightarrow$ Alphonsus Giercuszkiewicz

Glonka Josephus $\rightarrow$ Fabianus à S. Josepho

Gloza Josephus $\rightarrow$ Seraphinus à S. Josepho

Głowinski Joannes $\rightarrow$ Norbertus à S. Joanne

Głowiński Eustachius $\rightarrow$ Eustachius à S. Philippo Głowiński

Gniazdowski Ignatius $\rightarrow$ Anastasius à S. Ignatio

Godlewski Simon $\rightarrow$ Justinianus à S. Simone

Goldau Antonius $\rightarrow$ Henricus à S. Antonio

Golonka Josephus $\rightarrow$ Cyrillus à S. Josepho

Gorecki Thomas $\rightarrow$ Emilianus à $\mathrm{S}$. Thoma

Gorner (Gerner) Christophorus $\rightarrow$ Udalricus à S. Procopio

Gorner Antonius $\rightarrow$ Paulinus à S. Eliseo

Gorski (Lewald Gorski) Jacobus $\rightarrow$ Simon à S. Jacobo

Gorski Antonius $\rightarrow$ Arnoldus à S. Antonio

Gowarzewski Justinianus à S. Mathia $\rightarrow$ Justinianus à S. Mathia 
Gowinski Adalbertus $\rightarrow$ Anselmus à S. Adalberto

Gółkowski Amandus à S. Benedicto $\rightarrow$ Amandus à S. Benedicto

Grabinski Mathias $\rightarrow$ Thomas à S. Andreae Corsini

Grabowicz Jacobus $\rightarrow$ Franciscus à S. Jacobo

Grabowski Andreas $\rightarrow$ Casimirus à S. Andrea

Grabowski Paulus $\rightarrow$ Lambertus à S. Paulo

Grabowski Petrus $\rightarrow$ Eduardus à S. Petro (Thoma)

Gramzyc Mathias $\rightarrow$ Cyprianus à S. Gerardo

Granau Andreas $\rightarrow$ Bonaventura à S. Andrea

Graw Joannes $\rightarrow$ Leonardus à S. Joanne

Grąmbczewski Antonius $\rightarrow$ Xaverius à S. Antonio

Grenca Valentinus $\rightarrow$ Mansvetus à S. Valentino

Grenca Vincentius $\rightarrow$ Nepomucenus à S. Vincentio

Grentz Valentinus $\rightarrow$ Grenca Valentinus

Grębski Ludovicus $\rightarrow$ Ludovicus Grębski

Gręca Antonius $\rightarrow$ Lucas à S. Antonio

Gręca Nicolaus $\rightarrow$ Eugenius à S. Nicolao

Gręca Norbertus $\rightarrow$ Bonifacius à S. Norberto

Gronau Donatus $\rightarrow$ Donatus Gronau

Gruchalski Laurentius $\rightarrow$ Timotheus à S. Laurentio

Grzecznowski Dionysius $\rightarrow$ Dionysius Grzecznowski

Grzelakowski Gaspar $\rightarrow$ Robertus à S. Gasparo

Gurski Bertholdus $\rightarrow$ Eduardus à SS. Crispino \& Crispiniano

Gurski Paulus $\rightarrow$ Faustinus à S. Vincentio

Guttman Josephus $\rightarrow$ Narcissus à S. Josepho

Hahn Joannes $\rightarrow$ Thaddaeus à S. Joanne

Hahn Joannes $\rightarrow$ Vladislaus à S. Ludvico

Hahn Mathias $\rightarrow$ Adauctus à S. Mathia

Hainnicht Georgius $\rightarrow$ Bernardinus à S. Georgio

Hamerski Josephus à S. Adamo $\rightarrow$ Josephus à S. Adamo Hamerski

Hantchel Joannes $\rightarrow$ Martinianus à S. Joanne

Hanzolewicz Joannes $\rightarrow$ Paulus à S. Joanne

Hartel Godefridus $\rightarrow$ Philippus à S. Josepho

Hassmann Michael $\rightarrow$ Assmann Michael

Hennig Franciscus $\rightarrow$ Robertus à S. Francisco

Hertog Antonius $\rightarrow$ Florianus à S. Antonio

Hibner Antonius $\rightarrow$ Quinctinus à S. Antonio

Hoelle Josephus $\rightarrow$ Adrianus à S. Josepho

Holtz Joachimus $\rightarrow$ Fortunatus à S. Joachimo

Homan Joannes $\rightarrow$ Patritius à S. Gregorio

Hoppa Gaspar $\rightarrow$ David à S. Gasparo

Horodecki Michael $\rightarrow$ Andreas à S. Michaele

Hosztowski Adalbertus $\rightarrow$ Bertholdus à S. Adalberto

Hoyer Franciscus $\rightarrow$ Palladius à S. Francisco

Huhn Jacobus $\rightarrow$ Felix à S. Bernardo

Hypnarski Joannes $\rightarrow$ Fulgentius à S. Joanne à Cruce

Iwaczkowski Timotheus à S. Michaele $\rightarrow$ Timotheus à S. Michaele Iwaczkowski

Jaczynski Martinus $\rightarrow$ Bartholomaeus à S. Martino 
Jadachowski Anastasius $\rightarrow$ Anastasius Jadachowski

Jajko Augustinus à S. Thoma $\rightarrow$ Augustinus à S. Thoma Jajko

Jajko Fortunatus $\rightarrow$ Fortunatus Jajko

Janicki Albertus $\rightarrow$ Albertus Janicki

Janiszewski Franciscus $\rightarrow$ Eustachius à S. Adriano

Jankie Josephus $\rightarrow$ Archangelus à Monte Carmelo

Jankowski Adamus $\rightarrow$ Avertanus à SS. Petro \& Paulo

Jankowski Albertus $\rightarrow$ Francus à S. Alberto

Jankowski Antonius $\rightarrow$ Georgius à S. Antonio

Jankowski Franciscus $\rightarrow$ Evaristus à S. Francisco

Jankowski Jacobus $\rightarrow$ Gregorius à S. Jacobo

Janowicz Thomas à S. Ignatio $\rightarrow$ Thomas à S. Ignatio Janowicz

Jarecki Casimirus $\rightarrow$ Antonius à S. Casimiro

Jarząbkowski Mathias $\rightarrow$ Brocardus ab Ascensione Domini

Jastrzębski Thomas $\rightarrow$ Damasus à S. Thoma

Jaworski Joannes $\rightarrow$ Thaddaeus à S. Joanne

Jaworski Philibertus à S. Valentino $\rightarrow$ Philibertus à S. Valentino Jaworski

Jazdzewski Michael $\rightarrow$ Engelbertus à S. Michaele

Jedlinski Franciscus $\rightarrow$ Elias à S. Francisco

Jelinski Joannes $\rightarrow$ Thomas à S. Joachimo

Jerowski Michael $\rightarrow$ Romualdus à S. Michaele

Jędritzki Avertanus à S. Sabina $\rightarrow$ Avertanus à S. Sabina Jędritzki

Jordan Jacobus $\rightarrow$ Casimirus à S. Joanne Baptista

Julicki Mathaeus $\rightarrow$ Alphonsus à S. Mathaeo

Kadech Martinus $\rightarrow$ Theophilus à S. Martino

Kainski Jacobus $\rightarrow$ David à S. Justina

Kajewski Antonius $\rightarrow$ Gajewski Antonius

Kalinowski Mathias $\rightarrow$ Mathias Kalinowski

Kamalski Ignatius $\rightarrow$ Francus à S. Ignatio

Kami(e)nski Thelesphorus $\rightarrow$ Florentius à S. Thelesphoro

Kamieniecki Petrus $\rightarrow$ Francus à S. Norberto

Karnowski Paulus $\rightarrow$ Hyppolitus à SS. Petro \& Paulo

Karolewski Thomas $\rightarrow$ Placidus à S. Thoma

Karwaszewski Franciscus à S. Adalberto $\rightarrow$ Franciscus à S. Adalberto Karwaszewski

Kazmierski Anselmus à S. Michaele $\rightarrow$ Anselmus à S. Michaele Kazmierski

Kąsinowski Mathias $\rightarrow$ Michael à S. Mathia

Kegler Joannes $\rightarrow$ Dominicus à S. Joanne

Kelch Bertholdus à S. Francisco Xaverio $\rightarrow$ Bertholdus à S. Francisco Xaverio Kelch

Kembłowski Antonius $\rightarrow$ Franciscus à S. Josepho

Kęsicki Jacobus $\rightarrow$ Cyriacus à S. Jacobo

Kierfeld Thomas $\rightarrow$ Avertanus à S. Scholastica

Kijewski Anastasius à S. Michaele $\rightarrow$ Anastasius à S. Michaele Kijewski

Kilanowski Brocardus à S. Antonio $\rightarrow$ Brocardus à S. Antonio Kilanowski

Kilanowski Seraphinus $\rightarrow$ Seraphinus Kilanowski

Kiner Antonius $\rightarrow$ Dionysius à S. Antonio

Kiszka Norbertus $\rightarrow$ Norbertus Kiszka

Klawanski Michael $\rightarrow$ Carolus à S. Michaele

Klimkowski Jacobus $\rightarrow$ Constantinus à S. Jacobo

Klimkowski Josephus $\rightarrow$ Julianus à S. Josepho 
Klinger Antonius $\rightarrow$ Donatus à S. Antonio

Klinicki Joannes $\rightarrow$ Valentinus à S. Joanne Baptista

Kliniecki Joannes $\rightarrow$ Valerianus à S. Joanne Baptista

Kliszewski Gaspar $\rightarrow$ Barnabas à S. Gasparo

Kłossowski Jacobus $\rightarrow$ Theodorus à S. Jacobo

Knoch Georgius $\rightarrow$ Vladislaus à S. Joanne

Knop Joannes $\rightarrow$ Jacobus à S. Joanne

Knorr Antonius $\rightarrow$ Serapion à S. Brunone Pictor

Knorr Joannes $\rightarrow$ Antonius à S. Augustino

Kocer Daniel $\rightarrow$ Raymundus à S. Athanasio

Komierowski Casimirus $\rightarrow$ Constantinus à S. Laurentio

Komierowski Ignatius $\rightarrow$ Anastius à S. Joanne Nepomuceno

Komorowski Jacobus $\rightarrow$ Remigius à SS. Angelis Cust.

Konarzewski Stephanus $\rightarrow$ Martinianus à S. Anna

Konka Josephus $\rightarrow$ Capistranus à S. Josepho

Konopka Silvester $\rightarrow$ Silvester Konopka

Konoth Jacobus $\rightarrow$ Petrus à S. Jacobo

Koperszmyth Andreas $\rightarrow$ Erasmus à S. Andrea

Koperszmytt Andreas $\rightarrow$ Sylverius à S. Andrea

Koscielski Michael $\rightarrow$ Leodegarius à Matre Eva

Koscinski Casimirus à $\mathrm{S}$. Ludovico $\rightarrow$ Casimirus à S. Ludovico Koscinski

Koslinski Paulus $\rightarrow$ Gabriel à S. Cyrillo

Kosmalewicz Antonius $\rightarrow$ Florianus à S. Urbano

Kosmowski Nicolaus $\rightarrow$ Petrus Thomas à S. Agnete

Kossakowski Hyppolitus $\rightarrow$ Venantius à S. Hyppolito

Kostrzycki Casimirus $\rightarrow$ Kostrzynski Casimirus

Kostrzynski Casimirus $\rightarrow$ Raymundus à S. Casimiro

Kowalkowski Clemens $\rightarrow$ Clemens Kowalkowski

Kowalkowski Dominicus $\rightarrow$ Franquillinus à S. Dominico

Kowalski Martinus $\rightarrow$ Ildephonsus à S. Martino

Kozłowski Ludovicus $\rightarrow$ Clemens à S. Andrea

Kozłowski Stepanus $\rightarrow$ Crispinianus à S. Stephano

Kraca Joannes $\rightarrow$ Alexander à S. Joanne

Kramer Joannes $\rightarrow$ Martinus à S. Didaco

Kraska Jacobus $\rightarrow$ Philippus à S. Jacobo

Krassowski Bernardus $\rightarrow$ Marcellinus à Venerabili Sacramento

Krassowski Stanislaus $\rightarrow$ Bernardinus (Bernardus) ab Assumptione B.M.V.

Kraus Josephus $\rightarrow$ Eugenius à S. Romano

Krauz Valentinus $\rightarrow$ Joachimus à S. Valentino

Kreczmer Martinus $\rightarrow$ Cajetanus à S. Raymundo

Kreibich Joannes $\rightarrow$ Bernardinus à S. Simone

Krol Columbanus $\rightarrow$ Columbanus Krol

Krolikowski Antonius $\rightarrow$ Onuphrius à S. Antonio

Kruczkowski Michael $\rightarrow$ Caelestinus à S. Michaele

Krügier Joannes $\rightarrow$ Benedictus à S. Ignatio

Kruszewski Vincentius $\rightarrow$ Vincentius Kruszewski

Kruza Josephus $\rightarrow$ Cornelius à S. Josepho

Krykont Michael $\rightarrow$ Hilarion à S. Michaele

Krzeminski Bernardus $\rightarrow$ Gratianus à S. Bernardo 
Krzyzanowski Jacobus $\rightarrow$ Hyacinthus à S. Jacobo

Księżniewski Emilianus $\rightarrow$ Emilianus Księżniewski

Kubalski Felicianus à S. Joanne Nepomuceno $\rightarrow$ Felicianus à S. Joanne Nepomuceno

Kuchn Michael $\rightarrow$ Benno à S. Michaele

Kuczkie Adalbertus $\rightarrow$ Kutski Adalbertus

Kuczwalski Stanislaus $\rightarrow$ Faustinus à S. Stanislao

Kuhn Andreas $\rightarrow$ Eadmundus à S. Andrea à Annis

Kuhn Laurentius $\rightarrow$ Gaspar à SS. Angelis

Kulaszewski Casimirus $\rightarrow$ Damianus à S. Casimiro

Kulczycki Joannes $\rightarrow$ Laurentius à S. Joanne

Kunigk Clemens à S. Pontiano $\rightarrow$ Clemens à S. Pontiano Kunigk

Kunigk Joannes $\rightarrow$ Joannes à S. Clemento

Kutski Adalbertus $\rightarrow$ Martinianus à S. Adalberto

Kutzkie Adalbertus $\rightarrow$ Kutski Adalbertus

Kwasniewski Joannes $\rightarrow$ Melchior à S. Joanne Baptista

Kwoka Joachimus $\rightarrow$ Joachimus Kwoka

Ladach Ignatius $\rightarrow$ Hilarius à S. Ignatio

Langhanig Casimirus $\rightarrow$ Cyprianus à S. Casimiro

Lasota Antonius $\rightarrow$ Josephus à S. Antonio

Laus Jacobus $\rightarrow$ Vincentius à S. Jacobo

Lauterbach Joannes $\rightarrow$ Cyriacus à S. Cajetano

Lesman Franciscus $\rightarrow$ Fortunatus à S. Francisco

Lesnau Corsinus à S. Josepho $\rightarrow$ Corsinus à S. Josepho Lesnau

Lesnau Franciscus $\rightarrow$ Lesman Franciscus

Lewandoski Joannes $\rightarrow$ Corsinus à S. Joanne

Lewinski Petrus $\rightarrow$ Fulgentius à S. Petro

Lewiński Casimirus à $\mathrm{S}$. Ignatio $\rightarrow$ Casimirus à S. Ignatio Lewiński

Lewkowski Michael $\rightarrow$ Hyacinthus à S. Michaele

Lewski Ambrosius $\rightarrow$ Faustinus à S. Ambrosio

Link Andreas $\rightarrow$ Lucas à S. Andrea

Linkiewicz Michael Stanislaus $\rightarrow$ Epiphanius à Nativitate B.M.V.

Lipiński Simon à S. Nicolao $\rightarrow$ Simon à S. Nicolao Lipiński

Lissowski Paulus $\rightarrow$ Basilius à S. Paulo

Lorentz Joannes $\rightarrow$ Thaddaeus à S. Joanne Evangelista

Luba Sebastianus $\rightarrow$ Antonius à S. Sebastiano

Lurkowski Joannes $\rightarrow$ Modestus à S. Joanne

Lazarowicz Richardus $\rightarrow$ Richardus Łazarowicz

Łęsicki Jacobus $\rightarrow$ Christophorus à S. Jacobo

Łukaszewicz Bertholomaeus $\rightarrow$ Spiridion ab Immaculata Conceptione B.M.V.

Łuszczewicz Sebastianus $\rightarrow$ Corsinus à S. Sebastiano

Łyszkiewicz Jacobus $\rightarrow$ Jacobus Łyszkiewicz

Łyszniewski Joannes $\rightarrow$ Basilius à S. Joanne

Machajewski Marianus $\rightarrow$ Marianus Machajewski

Maciak Martinus $\rightarrow$ Martinus Maciak

Maciejczak Aloysius $\rightarrow$ Aloysius Maciejczak

Macinski Petrus $\rightarrow$ Paulus à S. Petro

Maczul Aloysius à S. Joannes $\rightarrow$ Aloysius à S. Joannes Maczul

Magawka Petrus $\rightarrow$ Valerianus à S. Anna 
Majewski Adalbertus $\rightarrow$ Avertanus ab Ascensione Domini

Majewski Joannes $\rightarrow$ Franciscus à S. Joanne

Makowski Adalbertus $\rightarrow$ Antonius à S. Alberto

Makowski Stanislaus à S. Adalberto $\rightarrow$ Stanislaus à S. Adalberto Makowski

Malick Carolus $\rightarrow$ Carolus Malick

Malisiewicz Michael $\rightarrow$ Moliszewicz Michael

Maliszewski Eliseus à S. Joanne $\rightarrow$ Eliseus à S. Joanne Maliszewski

Maliszewski Venantius à S. Mathaeo $\rightarrow$ Venantius à S. Mathaeo Maliszewski

Małachowski Stanislaus à S. Paulo $\rightarrow$ Stanislaus à S. Paulo Małachowski

Małecki Urbanus à S. Bernardo $\rightarrow$ Urbanus à S. Bernardo Małecki

Mamelski Bertholdus $\rightarrow$ Bertholdus Mamelski

Marcinkiewicz Paulus $\rightarrow$ Silvester à S. Paulo

Marlikiewicz Josephus $\rightarrow$ Basilius à Purificatione B.M.V.

Marszałkowski Valentinus $\rightarrow$ Robertus à S. Valentino

Maszkiewicz Andreas $\rightarrow$ Josephus à S. Onuphrio

Maszynski Jacobus $\rightarrow$ Adrianus à S. Jacobo

Mataski Joannes $\rightarrow$ Elias à Monte Carmeli

Matszulkie (Matszydkie) Stanislaus $\rightarrow$ Quirinus à S. Daciano

May Joannes $\rightarrow$ Zacharis à V. Sacramus

Mądrzycki Felicianus à S. Felice $\rightarrow$ Felicianus à S. Felice Mądrzycki

Menia Adalbertus $\rightarrow$ Sebastianus à S. Adalberto

Menia Martinus $\rightarrow$ Adrianus à S. Martino

Merucki Andreas $\rightarrow$ Boruski Andreas

Metz Joannes $\rightarrow$ Theodorus à S. Joanne

Metzel Salomon $\rightarrow$ Modestus à S. Benedicto

Mez Adamus $\rightarrow$ Kilianus à S. Adamo

Miaskowski Mathaeus à S. Adalberto $\rightarrow$ Mathaeus à S. Adalberto Miaskowski

Michalski Donatus à S. Michaele $\rightarrow$ Donatus à S. Michaele Michalski

Michałowski Carolus $\rightarrow$ Sebastianus à Desponsatione B.M.V.

Mierzwicki Dionysius $\rightarrow$ Dionysius Mierzwicki

Miklajewicz Joannes $\rightarrow$ Henricus à S. Joanne

Mikowski Martinus $\rightarrow$ Petrus Thomas à S. Martino

Miller Antonius $\rightarrow$ Felix à S. Antonio

Miller Joannes $\rightarrow$ Nepomucenus à Conversione S. Pauli

Mitkiewicz Josephus $\rightarrow$ Josephus à S. Apollonia

Moczynski Adalbertus $\rightarrow$ Brocardus à S. Adalberto

Moderski Antonius $\rightarrow$ Mathias à S. Casimiro

Modrzynski Joannes $\rightarrow$ Ambrosius à S. Joanne

Moliszewicz Michael $\rightarrow$ Gregorius à S. Michaele

Molsdrroff Severinus $\rightarrow$ Ananias à S. Severino

Montewski Simon $\rightarrow$ Justus à S. Simone

Moraczewski Josephus $\rightarrow$ Capistranus à S. Cypriano

Morawski Joannes $\rightarrow$ Elias à S. Joanne

Morawski Josephus $\rightarrow$ Timotheus à S. Josepho

Moroszewski Adalbertus (Josephus) $\rightarrow$ Eusebius à S. Josepho

Morzychowski Joannes $\rightarrow$ Carolus à S. Leonardo

Moszczynski Augustinus à S. Simone $\rightarrow$ Muszczyński Augustinus à S. Simone

Mrówczyński Eliseus à S. Stanislao $\rightarrow$ Eliseus à S. Stanislao Mrówczyński

Mulinski Petrus $\rightarrow$ Ulinski Petrus 
Murkiewicz Venantius à S. Valentino $\rightarrow$ Venantius à S. Valentino Murkiewicz

Murzynowski Andreas $\rightarrow$ Ubaldus à S. Andrea

Murzynowski Josephus $\rightarrow$ Joannes à S. Cruce à S. Francisco

Muszczyński Augustinus à S. Simone $\rightarrow$ Augustinus à S. Simone Muszczyński

Mykowski Martinus $\rightarrow$ Mikowski Martinus

Nagalski Hyacinthus $\rightarrow$ Hyacinthus Nagalski

Nakielski Antonius $\rightarrow$ Cherubinus à S. Antonio

Narkiewicz Laurentius à S. Antonio $\rightarrow$ Laurentius à S. Antonio Narkiewicz

Narwinski Hyacinthus $\rightarrow$ Silvester à S. Hyacintho

Nerman Nicolaus $\rightarrow$ Romaeus à S. Nicolao

Neullen Petrus $\rightarrow$ Theodoricus à S. Petro

Neuman Mathias $\rightarrow$ Isidorus à S. Mathia

Neuman Petrus $\rightarrow$ Martinus à S. Petro

Neyman Ignatius $\rightarrow$ Paphnutius à S. Placido

Nicinski Ignatius $\rightarrow$ Raymundus à S. Ignatio

Niemczewski Joannes $\rightarrow$ Florentius à S. Joanne's X.

Nierzalewski Joannes $\rightarrow$ Avertanus à S. Joanne

Niewiecki Joannes $\rightarrow$ Stephanus à S. Joanne

Nogowski Mathaeus $\rightarrow$ Elias à S. Mathaeo

Nowaczewski Fulgentius $\rightarrow$ Fulgentius Nowaczewski

Nowi Josephus $\rightarrow$ Balthassar à S. Josepho

Nowicki Petrus $\rightarrow$ Honorius à S. Petro

Nowinski Antonius $\rightarrow$ Victor à S. Antonio

Nowogorski Antonius $\rightarrow$ Gabriel à S. Antonio

Nuszkowski Casimirus $\rightarrow$ Thomas à Nativitate Domini

Ochlewski Petrus Thomas $\rightarrow$ Petrus Thomas Ochlewski

Oczkowski Joannes Nepomucenus à S. Casimiro $\rightarrow$ Joannes Nepomucenus à S. Casimiro

Oliszewski Adalbertus $\rightarrow$ Olszak Adalbertus

Olszak (Oliszewski) Adalbertus $\rightarrow$ Eliseus à S. Alberto

Olszewski Josephus $\rightarrow$ Josephus Olszewski

Opalinski Joannes $\rightarrow$ Stanislaus à S. Teresia

Orłowski Joannes $\rightarrow$ Patritius à S. Joanne

Ornowski Angelinus à S. Michaele $\rightarrow$ Angelinus à S. Michaele Ornowski

Osinski Onuphrius à S. Antonio $\rightarrow$ Onuphrius à S. Antonio Osinski

Ossowski Gabriel $\rightarrow$ Eliseus à S. Gabriele

Ostaszewski Sebastianus $\rightarrow$ Victor à S. Josepho

Ostrowicki Alexander $\rightarrow$ Nicolaus à S. Aloysio

Ostrowski Ambrosius à S. Joanne $\rightarrow$ Ambrosius à S. Joanne Ostrowski

Otręmbka David $\rightarrow$ Quirinus à S. Davidi

Owidzki Thomas $\rightarrow$ Erasmus à S. Joanne Nepomuceno

Owsiany Polykarpus $\rightarrow$ Polykarpus Owsiany

Packowski Mathaeus $\rightarrow$ Onuphrius ab Annut. B.M.V.

Pagorselski Thomas $\rightarrow$ Paulus à S. Thoma

Parchiem Josephus $\rightarrow$ Cantius à S. Josepho

Parzau Michael $\rightarrow$ Dionysius à S. Michaele

Patucki Simon $\rightarrow$ Romualdus à S. Simone

Pączkowski Mathias $\rightarrow$ Eduardus à S. Mathaeo

Pepłowski Albinus $\rightarrow$ Albinus Pepłowski 
Perczyński Laurentius $\rightarrow$ Pierzcinski Laurentius

Peterr Josephus $\rightarrow$ Clemens à S. Josepho

Piasecki Cassianus à S. Joanne $\rightarrow$ Cassianus à S. Joanne Piasecki

Piątkowski Adamus $\rightarrow$ Bernardus à S. Joanne Evangelista

Piechowicz Mateusz $\rightarrow$ Venceslaus à S. Mathaeo

Piekarski Adalbertus $\rightarrow$ Eusebius à S. Adalberto

Pierzcinski Laurentius $\rightarrow$ Melchior à S. Laurentio

Pierzkatowski Christophorus $\rightarrow$ Guilielmus à S. Christophoro

Pilarski Laurentius $\rightarrow$ Clemens à S. Pontiano

Pilawski Andreas $\rightarrow$ Seraphinus à S. Andrea

Piotrowicz Antonius $\rightarrow$ Augustinus à S. Antonio

Piotrowicz Xaverius $\rightarrow$ Xaverius à S. Alberto

Piotrowski Josephus $\rightarrow$ Laurentius à S. Josepho

Piotrowski Simon $\rightarrow$ Bonaventura à S. Simone

Piotrowski Simon $\rightarrow$ Gerardus à S. Simone

Piper Laurentius $\rightarrow$ Philibertus à S. Marco

Pittat Longinus $\rightarrow$ Longinus Pittat

Plewiński Ubaldus à S. Vincentio $\rightarrow$ Ubaldus à S. Vincentio Plewiński

Pobłocki Joannes $\rightarrow$ Alanus à S. Gerardo

Pohl Ambrosius $\rightarrow$ Tobias à S. Crispino

Pohl Franciscus $\rightarrow$ Nepomucenus à S. Francisco

Pokorzynski Valentinus $\rightarrow$ Cassianus à S. Valentino

Polakiewicz Norbertus $\rightarrow$ Josaphat à S. Norberto

Polejowski Adalbertus $\rightarrow$ Chrysostomus à S. Adalberto

Połczyński Victorianus $\rightarrow$ Victorianus Połczyński

Pomorski Bonaventura à S. Bartolomaeo $\rightarrow$ Bonaventura à S. Bartolomaeo Pomorski

Ponka Joannes $\rightarrow$ Paulinus à S. Joanne

Ponka Zacharias à S. Christophoro $\rightarrow$ Zacharias à S. Christophoro Ponka

Popławski Josephus $\rightarrow$ Severinus à S. Josepho

Pracki Michael $\rightarrow$ Hieronymus à S. Michaele

Preuss Joannes $\rightarrow$ Simeon à S. Joanne

Pruszkowski Valentinus $\rightarrow$ Hieronymus à S. Valentino

Przyborowski Joannes $\rightarrow$ Gerardus à S. Joanne

Przybylinski Valentinus $\rightarrow$ Norbertus à S. Valentino

Rabski Michael $\rightarrow$ Evaristus à S. Michaele

Racięski Stanislaus $\rightarrow$ Onuphrius à S. Anna

Radoszewski Antonius $\rightarrow$ Antonius à S. Andrea Corsini

Radoszewski Mathaeus à S. Joanne $\rightarrow$ Mathaeus à S. Joanne Radoszewski

Radwenski Josephus $\rightarrow$ Isaac à S. Jacobo

Radzikowski Seraphinus $\rightarrow$ Leo à S. Adalberto

Rafałowicz Andreas $\rightarrow$ Casimirus à $\mathrm{S}$. Andrea

Rahn Josephus $\rightarrow$ Evodius à S. Josepho

Ratnan Franciscus $\rightarrow$ Andreas à S. Francisco

Rauthe Venceslaus $\rightarrow$ Marianus à S. Nicomede

Reich Georgius $\rightarrow$ Joachimus à S. Georgio

Remberkowicz Valentinus $\rightarrow$ Vitalis à S. Valentino

Renkie Franciscus $\rightarrow$ Lambertus à S. Francisco

Robaszkiewicz Joannes $\rightarrow$ Cajetanus à S. Joanne

Robota Gabriel $\rightarrow$ Gabriel Robota 
Rogalla Josephus $\rightarrow$ Rochus à S. Josepho

Rojewski Josephus $\rightarrow$ Rozewski Josephus

Rokicki Thaddaeus $\rightarrow$ Franciscus à S. Antonio

Roman Casimirus $\rightarrow$ Casimirus Roman

Romanowski Joannes $\rightarrow$ Valerius à S. Joanne

Ronge Augustinus $\rightarrow$ Lambertus à $\mathrm{S}$. Augustino

Roszak Franciscus $\rightarrow$ Paulinus à S. Francisco

Rozewski Josephus $\rightarrow$ Valentinus à S. Josepho

Rożewicz Josephus à S. Joanne $\rightarrow$ Josephus à S. Joanne Rozewicz

Ruchniewicz Ignatius $\rightarrow$ Jacobus ab Omnibius Sanctis

Ruchniewicz Martinus $\rightarrow$ Albertus à SS. Joanne \& Paulo

Rudnicki Constantinus $\rightarrow$ Timotheus à S. Constantino

Rumczynski Joannes $\rightarrow$ Donatus à S. Joanne

Rutkowski Philippus $\rightarrow$ Philippus Rutkowski

Rybinski Laurentius $\rightarrow$ Eliseus à S. Laurentio

Rync Hyacinthus $\rightarrow$ Philippus à S. Joanne Baptista

Rzepecki Philippus $\rightarrow$ Innocentius à S. Philippo

Rzeszotarski Marcellinus à S. Joanne $\rightarrow$ Marcellinus à S. Joanne Rzeszotarski

Sadkowski Ignatius $\rightarrow$ Hyacinthus à S. Ignatio

Sadowicz Paulus $\rightarrow$ Caelestinus à SS. Trinitte

Salomon Fridericus $\rightarrow$ Tiburtius à S. Friderico

Sankowski Petrus $\rightarrow$ Polykarpus à S. Petro

Sarnowski Ignatius $\rightarrow$ Dionysius à $\mathrm{S}$. Ignatio

Sarnowski Joannes $\rightarrow$ Cyrillus à S. Basilio

Sarnowski Josephus $\rightarrow$ Caelestinus à S. Josepho

Satorski Lucas $\rightarrow$ Cyprianus à S. Gerardo

Sawicki Bartholomaeus $\rightarrow$ Nicolaus à S. Bartholomaeus

Schmid Michael $\rightarrow$ Francus à S. Michaele

Schmidt Ludovicus $\rightarrow$ Avertanus à S. Ludovico

Schmitt Joannes $\rightarrow$ Felix à S. Joanne

Schmitt Theodorus $\rightarrow$ Serapion à S. Theodoro

Schneider Joannes $\rightarrow$ Christophorus à SS. Trinitate

Schnigenberg Josephus $\rightarrow$ Theodosius à S. Josepho

Schonse Joannes $\rightarrow$ Raphael à S. Joanne

Schreiber Constantinus $\rightarrow$ Isidorus à S. Constantino

Schröder Michael $\rightarrow$ Szreder Michael

Schroeder Cajetanus $\rightarrow$ Cajetanus Schroeder

Schtüler Martinus $\rightarrow$ Szirller Martinus

Schultz Josephus $\rightarrow$ Euthymius à S. Josepho

Schultz Martinus $\rightarrow$ Methodius à S. Martino

Schultz Mathias $\rightarrow$ Amandus à S. Mathia

Schütz Benjamin $\rightarrow$ Caelestinus ab Ascensione Domini

Schwald Josephus $\rightarrow$ Marcianus à S. Josepho

Sczepanski Joannes $\rightarrow$ Michael à S. Joanne Baptista

Sczerbic Antonius $\rightarrow$ Andreas à S. Spiritu ex Anti. (Jurisperitus)

Sczypalski Franciscus $\rightarrow$ Silvester à S. Joanne Evangelista

Sebastyanski Bartholomaeus $\rightarrow$ Stephanus à S. Alberto

Sebastyanski Petrus $\rightarrow$ Brocardus à S. Stanislao

Sekulski Andreas $\rightarrow$ Gabriel à S. Luca 
Siekowicz Jacobus $\rightarrow$ Mauritius à S. Jacobo

Sielski Andreas $\rightarrow$ Richardus à S. Andrea

Siemierowski Georgio $\rightarrow$ Siemierowski Ignatius

Siemierowski Ignatius $\rightarrow$ Urbanus à S. Georgio

Siennicki Aloysius à S. Josepho $\rightarrow$ Aloysius à S. Josepho Siennicki

Sieradzki Chrisologus à S. Constantino $\rightarrow$ Chrisologus à S. Constantino Sieradzki

Sierawski Thomas $\rightarrow$ Ludovicus à S. Thoma

Sieroinski Andreas $\rightarrow$ Hyppolitus à S. Alberto

Sikorski Lucas $\rightarrow$ Julianus à S. Antonio

Sikorski Mathias $\rightarrow$ Cajetanus à S. Mathia

Skęmpski Martinus $\rightarrow$ Chrisologus à S. Martino

Skibinski Petrus $\rightarrow$ Gervasius à S. Bartholomeo

Skierkowski Elias à S. Josepho $\rightarrow$ Elias à S. Josepho Skierkowski

Skoczynski Petrus $\rightarrow$ Bertholdus à S. Petro

Skok Christianus $\rightarrow$ Expeditus à S. Christiano

Skrzyński Zacharia à S. Casimiro $\rightarrow$ Zacharia à S. Casimiro Skrzyński

Slewinski Simon $\rightarrow$ Rochus à S. Simone

Sobanski Stanislaus $\rightarrow$ Eustachius à Venerabili Sacramento

Sobierzynski Valentinus $\rightarrow$ Aloysius à S. Petro

Sokołowski Cornelius $\rightarrow$ Cornelius Sokołowski

Solecki Mathias $\rightarrow$ Ignatius à Purificat B.M.V.

Sperowski Melchior $\rightarrow$ Melchior Sperowski

Staniszewski Valentinus $\rightarrow$ Rochus à S. Valentino

Stawski Petrus $\rightarrow$ Arsenius à S. Petro

Stefanski Franciscus $\rightarrow$ Camillus à S. Francisco

Stęfikiewicz Antonius $\rightarrow$ Marianus à S. Antonio

Stolinski Joannes $\rightarrow$ Samuel à $S$. Joanne

Stoll Petrus $\rightarrow$ Cornelius à S. Michaele

Straus Andreas $\rightarrow$ Francus à SS. Simone \& Juda

Stroinski Albertus $\rightarrow$ Norbertus à S. Angelo

Stroinski Thomas $\rightarrow$ Anastasius à S. Thoma

Stucki Michael $\rightarrow$ Crispinus à S. Michaele

Stupniewski Adalbertus $\rightarrow$ Michael à S. Adalberto

Styller Jacobus $\rightarrow$ Godefridus à S. Jacobo

Suczynski Stephanus $\rightarrow$ Romualdus à S. Simone

Sulejowski Mathias $\rightarrow$ Medardus à S. Mathia

Swierbel Josephus $\rightarrow$ Benedictus à S. Josepho

Swieykowski Josephus $\rightarrow$ Aloysius à S. Josepho

Szałwiński Bruno à S. Michaele $\rightarrow$ Bruno à S. Michaele Szałwiński

Szandel Ignatius $\rightarrow$ Ludovicus à $\mathrm{S}$. Ignatio

Szanowski Hyacinthus $\rightarrow$ Barnabas à S. Hyacintho

Szanowski Joannes $\rightarrow$ Christianus à S. Joanne

Szatwicki Josephus $\rightarrow$ Athanasius à S. Josepho

Szcholtzt Franciscus $\rightarrow$ Brocardus à S. Francisco

Szchur Josephus $\rightarrow$ Norbertus à S. Josepho

Szczechowski Andreas $\rightarrow$ Serapion à S. Andrea

Szejski Josephus $\rightarrow$ Longinus à S. Josepho

Szirller Martinus $\rightarrow$ Sigismundus à S. Martino

Szmerlinski Joannes $\rightarrow$ Michael à S. Joanne 
Szmuk Joannes $\rightarrow$ Evaristus à S. Joanne

Szmurlenski Andreas $\rightarrow$ Romaeus à Nativitate Domini

Szpecht Paulus $\rightarrow$ Dionysius à S. Paulo

Szpotanski Petrus $\rightarrow$ Albinus à S. Gregorio

Szpotanski Stanislaus $\rightarrow$ Petrus à S. Stanislao

Szramowski Joannes $\rightarrow$ Fortunatus à S. Joanne

Szreder (Schröder) Michael $\rightarrow$ Bruno à S. Francisco

Sztiller Martinus $\rightarrow$ Szirller Martinus

Sztoltz Franciscus $\rightarrow$ Caprasius à S. Francisco

Szulc Henricus $\rightarrow$ Florianus à S. Henrico

Szumacher Antonius $\rightarrow$ Lambertus à S. Antonio

Szumakowski Alexius $\rightarrow$ Alexius Szumakowski (Szymakow)

Szumicki Antonius $\rightarrow$ Theodorus à S. Caecilia

Szweykowski Balthasar $\rightarrow$ Ferdinandus à S. Cassiano

Szweykowski Valentinus $\rightarrow$ Reginaldus à S. Alberto

Szymakow Alexius $\rightarrow$ Alexius Szumakowski (Szymakow)

Szymanowicz Adalbertus $\rightarrow$ Dismas à S. Adalberto

Szyskowski Casimirus $\rightarrow$ Cyrillus à S. Casimiro

Taszewski Michael $\rightarrow$ Mauritius à S. Georgio

Taube Franciscus $\rightarrow$ Adalbertus (Albertus) à S. Francisco

Teichert Adalbertus $\rightarrow$ Placidus à S. Michaele

Tempski Joannes $\rightarrow$ Albertus à S. Joanne

Theyler Augustinus $\rightarrow$ Seraphinus à S. Augustino

Thyla Antonius $\rightarrow$ Nicolaus à S. Antonio

Toczynski Franciscus $\rightarrow$ Albinus à S. Caecilia

Tokarski Joannes $\rightarrow$ Epiphanius à S. Saturnino

Tokarski Michael $\rightarrow$ Processus à S. Visitatione B.M.V.

Tomaczykowski Albertus $\rightarrow$ Hieronymus à S. Michaele

Tomaszewski Josephus $\rightarrow$ Vladislaus à S. Josepho

Tomaszewski Martinus $\rightarrow$ Josephus à S. Martino

Topolczik Paulus $\rightarrow$ Anselmus à S. Maria

Trepczyk Leopoldus $\rightarrow$ Leopoldus Trepczyk

Truszczynski Joannes $\rightarrow$ Petrus à S. Teresia

Trzciński Gervasius à S. Antonio $\rightarrow$ Gervasius à S. Antonio

Trzebicki Victor $\rightarrow$ Josephus à S. Disma

Turowski Antonius $\rightarrow$ Vincentius à S. Antonio

Ulinski (Mulinski) Petrus $\rightarrow$ Paulus à S. Floriano

Urzyczkowski Michael $\rightarrow$ Felicianus à S. Michaele

Vober Joannes $\rightarrow$ Daniel à S. Joanne

Vomberg Theodorus à S. Antonio $\rightarrow$ Theodorus à S. Antonio Vomberg

Wagner Josephus $\rightarrow$ Gerardus à S. Josepho

Walczak Stanislaus $\rightarrow$ Stanislaus Walczak

Waldowski Michael $\rightarrow$ Sebaldus à S. Michaele

Walicki Josephus $\rightarrow$ Cherubinus à S. Josepho

Wallis Joannes $\rightarrow$ Ferdinandus à S. Joanne

Walnowski Petrus $\rightarrow$ Marcianus à S. Petro

Wałczyński Josephus $\rightarrow$ Venantius ab Inventio S. Crucis

Wasiłowski Alexius à S. Andrea $\rightarrow$ Alexius à S. Andrea Wasiłowski 
Wasztel Cornelius à S. Jacobo $\rightarrow$ Cornelius à S. Jacobo Wasztel

Welki Josephus $\rightarrow$ Eliseus à S. Maria Magdalena de Pazzis

Werner Josephus $\rightarrow$ Conradus à S. Chrysogomo

Werski Georgius $\rightarrow$ Venceslaus à S. Georgio

Wesołowski Basilius à S. Christophoro $\rightarrow$ Basilius à S. Christophoro Wesołowski

Weychan Ignatius $\rightarrow$ Cantius à $\mathrm{S}$. Ignatio

Węgierski Petrus $\rightarrow$ Leonardus à S. Joanne à Cruce

Wichert Andreas $\rightarrow$ Macarius à S. Andrea

Wieczorkiewicz Petrus $\rightarrow$ Narcissus à S. Zacharis

Wierzbicki Valerianus $\rightarrow$ Valerianus Wierzbicki

Więckowski Alexius $\rightarrow$ Carolus à S. Bartholdo

Wilk Simon $\rightarrow$ Theophilus à S. Simone

Winiecki Josephus $\rightarrow$ Simon à S. Norberto

Winkler Valentinus $\rightarrow$ Fabianus à S. Valentino

Winkowski Leo à S. Andrea $\rightarrow$ Leo à S. Andrea Winkowski

Winter Michael $\rightarrow$ Michael à S. Joanne

Wisniewski Franciscus $\rightarrow$ Tiburtius à S. Francisco

Witkowski Jacobus $\rightarrow$ Erasmus à S. Jacobo

Witkowski Martinus $\rightarrow$ Serapion à S. Dionysio

Wliklinski Josephus $\rightarrow$ Ludovicus à S. Josepho

Wobb Josephus $\rightarrow$ Onuphrius à S. Josepho

Woitowski Ignatius $\rightarrow$ Angelinus à S. Ignatio

Wolff Paulus $\rightarrow$ Ildephonsus à S. Paulo

Wolff Simon $\rightarrow$ Wilk Simon

Wolffen Antonius $\rightarrow$ Alexius à S. Antonio

Wolinski Josephus $\rightarrow$ Theodorus à S. Josepho

Wolki Mathias $\rightarrow$ Simon à S. Mathia

Wolschon Josephus à S. Ignatio $\rightarrow$ Josephus à S. Ignatio Wolschon

Wolski Antonius $\rightarrow$ Vladislaus à S. Antonio

Wolski Mathias $\rightarrow$ Boguslaus à S. Josepho

Wolski Nicolaus $\rightarrow$ Julius à S. Teresia

Wolski Vladislaus $\rightarrow$ Joannes à S. Vladislao

Wołęcki Josephus $\rightarrow$ Albinus à S. Casimiro

Wołoszko Albertus $\rightarrow$ Casimirus à S. Alberto (Adalberto)

Wołynkiewicz Simon $\rightarrow$ Benignus à S. Simone

Woycicki Valentinus $\rightarrow$ Thelesphorus à S. Valentino

Woyciechowski Ludovicus $\rightarrow$ Albinus à S. Ludovico

Woyciechowski Mathias $\rightarrow$ Josephus à S. Mathia

Woycziechowski Jacobus $\rightarrow$ Gregorius à S. Jacobo

Woytkowski Ignatius $\rightarrow$ Angelinus à S. Ignatio

Wróblewski Ceslaus $\rightarrow$ Ceslaus Wróblewski

Wryczkowski Michael $\rightarrow$ Urzyczkowski Michael

Wydryszewski Bonaventura à S. Antonio $\rightarrow$ Bonaventura à S. Antonio

Wyganowski Laurentius $\rightarrow$ Georgius à S. Laurentio

Wyganowski Stanislaus $\rightarrow$ Remigius à S. Josepho

Wylązek Albertus $\rightarrow$ Marianus à S. Spiridione

Wylma Petrus $\rightarrow$ Stanislaus à S. Petro

Wysocki Jacobus $\rightarrow$ Gerardus à S. Jacobo

Zaborowski Josephus $\rightarrow$ Mansvetus à S. Casto 
Zagerman Andreas $\rightarrow$ Aegidius à S. Andrea

Zagrodzki Ignatius $\rightarrow$ Marcianus à S. Ignatio

Zaiąkalski Joannes $\rightarrow$ Gabriel à S. Joanne Baptista

Zakrzewski Franciscus $\rightarrow$ Antonius à S. Francisco

Zalewski Antonius $\rightarrow$ Antonius Zalewski

Zalewski Antonius $\rightarrow$ Cherutinus à S. Antonio

Zalewski Laurentius $\rightarrow$ Jeremias à SS. Petro \& Paulo

Zaluski Michael $\rightarrow$ Franciscus ab Immaculata Conceptione B.V.M.

Zanc Mathaeus $\rightarrow$ Mathaeus Zanc

Zaremba Stanislaus $\rightarrow$ Adamus à S. Stanislao

Zarzycki Martinus $\rightarrow$ Andreas à S. Alexandro

Zasiecki Nicolaus $\rightarrow$ Patritius à Dulcissimo Nomine JEZU

Zawacki Clemens à S. Stanislao $\rightarrow$ Clemens à S. Stanislao Zawacki

Zawadzki Michael $\rightarrow$ Felix à S. Simone

Zbiiewski Ignatius $\rightarrow$ Adalbertus à S. Ignatio

Zbijewski Joannes Rochus $\rightarrow$ Valentinus à S. Agnete

Zbitkiewicz Clemens $\rightarrow$ Thadaeus à S. Clemento

Zdrojewski Vincentius à S. Adalberto $\rightarrow$ Vincentius à S. Adalberto Zdrojewski

Zdunkiewicz Gerardus $\rightarrow$ Gerardus Zdunkiewicz

Zdziarski Rochus $\rightarrow$ Rochus Zdziarski

Zegan Leopoldus $\rightarrow$ Leopoldus Zegan

Zelewski Stanislaus $\rightarrow$ Hilarion à S. Stanislao

Zelnerowski Adamus $\rightarrow$ Cornelius à S. Adamo

Zielewicz Laurentius $\rightarrow$ Carolus à S. Laurentio

Zielinski Franciscus $\rightarrow$ Leonardus à S. Francisco

Zielinski Paulus $\rightarrow$ Hyacinthus à S. Paulo

Ziemieniecki Joannes $\rightarrow$ Jacobinus à S. Joanne

Zieminski Franciscus $\rightarrow$ Valentinus à S. Francisco

Zięba Angelus $\rightarrow$ Angelus Zięba

Zinrow (Zyngier) Thomas $\rightarrow$ Mennas à S. Thoma

Zmigrodzki Marcus à S. Thadeo $\rightarrow$ Marcus à S. Thadeo Zmigrodzki

Zochowski Antonius $\rightarrow$ Hilarion à S. Antonio

Zuchowski Columbanus à S. Ladislao $\rightarrow$ Columbanus à S. Ladislao Zuchowski

Zukowski Casimirus $\rightarrow$ Adamus à S. Casimiro

Zurkowski Adalbertus $\rightarrow$ Paschasius à S. Adalberto

Zwiąska Bartholomaeus $\rightarrow$ Urbanus à S. Bartholomaeo

Zyngier Thomas $\rightarrow$ Zinrow Thomas

Żołądkiewicz Paulus $\rightarrow$ Lucas à S. Paulo 


\title{
THE CARMELITES OF THE ANCIENT OBSERVANCE IN THE GREAT POLAND PROVINCE IN THE 17TH-19TH CENTURIES
}

\begin{abstract}
Summary
The inspiration for writing this article was "A small chronicle of the residence of the Carmelites of the Ancient Observance in Poznań". The following work is the first study based on sources concerning directly the monks from the province of Great Poland. The presented data reflect only the information included in the given sources and publications and they are the basis for the further study on this monastic family. The study focuses on the Carmelites of the Ancient Observance in the Great Poland Province from 1686, the year when they came into their own, to the dissoluton of the orders in the $19^{\text {th }}$ century. The article is not the catalogue of the monks; it only shows the basic biographical details, which should be confronted with other sources. This source study does not follow the current standards either; it is only the compilation of a few sources. In this way we can gain more details about particular monks. These are not probably all monks of this province, and the subsequent manuscripts and publications will show new characters.
\end{abstract}

Translated by Aneta Kiper 